UNIVERSIDADE DE SÃO PAULO

FACULDADE DE FILOSOFIA, LETRAS E CIÊNCIAS HUMANAS DEPARTAMENTO DE FILOSOFIA

PROGRAMA DE PÓS-GRADUAÇÃO EM FILOSOFIA

MARCUS SACRINI A. FERRAZ

\title{
FENOMENOLOGIA E ONTOLOGIA EM MERLEAU-PONTY
}




\section{FENOMENOLOGIA E ONTOLOGIA EM MERLEAU-PONTY}

Tese apresentada ao Programa de PósGraduação do Departamento de Filosofia da Faculdade de Filosofia, Letras e Ciências Humanas da Universidade de São Paulo, sob a orientação do Prof. Dr. Carlos Alberto R. de Moura, como requisito parcial para obtenção do título de Doutor em Filosofia.

SÃO PAULO 


\section{Agradecimentos}

Ao professor Carlos Alberto, cuja orientação serena e rigorosa, e cujo exemplo de seriedade e tenacidade já há muitos anos fornecem a base para todas as minhas empreitadas acadêmicas;

Aos professores Franklin Leopoldo e Márcio Suzuki, pelas observações críticas extremamente úteis quando do exame de qualificação;

Ao professor Caetano Plastino, por várias sugestões e pela amizade constante;

Aos meus pais, Erlan e Belarmina;

À Andréa, minha esposa, pelo apoio e incentivo;

Aos amigos João Eduardo, Paulo Piva, João Abreu, Maurício Marsola, Marcelo Koch, Anderson Gonçalves, Natália Fujita, Leandro Cardim, e muitos outros, pelo convívio e aprendizado;

Aos funcionários da secretaria do departamento, especialmente Maria Helena, Marie, Geni, Luciana, Verônica e Ruben;

À FAPESP, cujo apoio foi imprescindível para a realização desse trabalho. 
"Para mim, a filosofia consiste em dar um outro nome ao que foi há muito tempo cristalizado sob esse nome de Deus" Merleau-Ponty, Parcours II, p.371. 


\section{RESUMO}

FERRAZ, M. S. A. Fenomenologia e ontologia em Merleau-Ponty. 2008. $271 \mathrm{f}$. Tese (Doutorado). Faculdade de Filosofia, Letras e Ciências Humanas. Departamento de Filosofia, Universidade de São Paulo, 2008.

Resumo: Neste trabalho, buscamos expor e avaliar as diferentes concepções de ser defendidas por Merleau-Ponty no decorrer de sua obra. De início, explicitamos a concepção ontológica contida na Fenomenologia da Percepção, e julgamos que ela está comprometida com conseqüências idealistas. Em seguida, acompanhamos como Merleau-Ponty esboça, em seus textos finais, uma concepção não idealista do ser, que admite um excesso daquilo que há em relação àquilo que se fenomenaliza.

Palavras-chave: ontologia - fenomenologia - Merleau-Ponty - idealismo - metafísica

FERRAZ, M. S. A. Phenomenology and Ontology in Merleau-Ponty. 2008. $271 \mathrm{f}$. Thesis (Doctorate). Faculdade de Filosofia, Letras e Ciências Humanas. Departamento de Filosofia, Universidade de São Paulo, 2008.

Abstract: In this work, we aim at showing and evaluating Merleau-Ponty's different conceptions of being held in his career. First, we make explicit the ontological conception included in his book Phenomenology of Perception, and we judge that such conception is committed to idealistic consequences. Then, we set forth how MerleauPonty outlines, in his final texts, a non-idealistic conception of being, which acknowledges that what there is exceeds what appears.

Keywords: ontology - phenomenology - Merleau-Ponty - idealism - metaphysics 


\section{Índice}

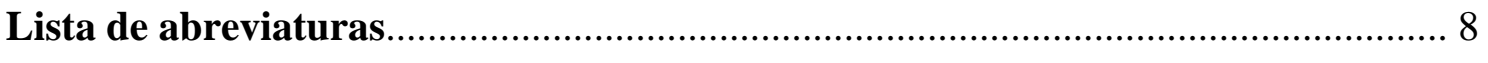

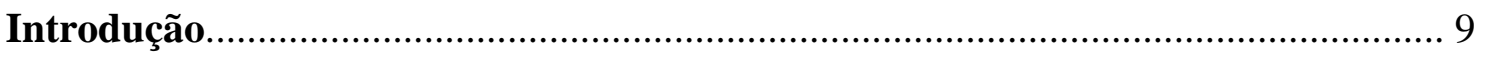

Capítulo I - Os impasses da ontologia fenomenológica de Merleau-Ponty..............18

A) As primeiras obras de Merleau-Ponty

A Estrutura do Comportamento. A Fenomenologia da Percepção.

B) As críticas ao projeto filosófico de Merleau-Ponty

Um estudo psicológico. Merleau-Ponty idealista. O problema do passado do mundo. A correlação perceptiva.

C) $\underline{\mathrm{O} \text { desenvolvimento da ontologia de Merleau-Ponty }}$

Capítulo II - Investigações sobre a linguagem.

A) Expressividade e consciência silenciosa

$\mathrm{O}$ papel da linguagem. A expressividade da fala. O problema do sentido gestual das palavras.

B) Apropriação da lingüística de Saussure

O escopo da expressividade. A expressividade e a lingüística de Saussure. Dois problemas da lingüística de Saussure. Crítica ao sentido gestual ou emotivo das palavras.

C) Percepção e linguagem

A percepção enformada culturalmente. A articulação entre vida perceptiva e atividade lingüística. A fixação dos dados sensíveis pela linguagem.

Capítulo III - Rumo ao ser primordial. 84

Introdução. A Instituição. A Passividade. Exemplos de passividade. A Natureza. Uma abordagem histórica. Ciência e natureza. O ser sensível. O corpo sensível. O ser negativo.

Capítulo IV - O método indireto da ontologia madura de Merleau-Ponty.

A)Filosofia e ciência

Convergências. Divergências. O método indireto. O duplo papel da ciência.

B) Generalização do método indireto

Análise de alguns fatos históricos. Análise da arte e da psicanálise. A ontologia cartesiana da visão. As dimensões invisíveis. As idéias sensíveis.

C) A linguagem filosófica como expressão criadora

Fixar as estruturas do ser. $\mathrm{O}$ modelo da filosofia como criação. Crítica à ontologia direta.

Capítulo V - Merleau-Ponty intérprete da fenomenologia.

A) O projeto fenomenológico de Merleau-Ponty

Apresentação. O estudo da percepção. Uma fenomenologia da experiência concreta. Observações críticas.

B) Novos dados indiretos para a ontologia

Fenomenologia e ciências humanas. O ser anterior à constituição. Os limites da fenomenologia.

Capítulo VI - Uma ontologia para a fé perceptiva.

A) A fé perceptiva

A última filosofia de Merleau-Ponty. Da percepção à fé perceptiva. O problema da ilusão.

B) As teorizações sobre a fé perceptiva

Esquema geral. Análise da ciência. A filosofia reflexiva. A ontologia sartreana. A interrogação filosófica.

A linguagem da filosofia. O problema das essências.

C) A base ontológica da fé perceptiva

A reversibilidade. A carne. O problema da amplitude do ser. 
Conclusão - Uma concepção de ser renovada.

A) Retomada geral

O problema do idealismo. O itinerário de Merleau-Ponty.

B) A carne

$\mathrm{O}$ método indireto da ontologia. A sensibilidade intrínseca ao ser. A comunidade carnal entre sujeito e mundo.

C) A negatividade inerente ao ser

O problema da correlação perceptiva. A invisibilidade. Uma nova teoria do tempo. O ser percebido e o ser sensível. Uma ontologia metafísica?

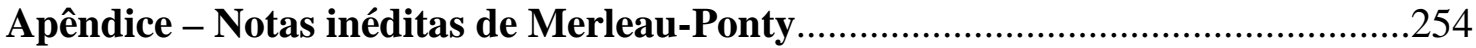

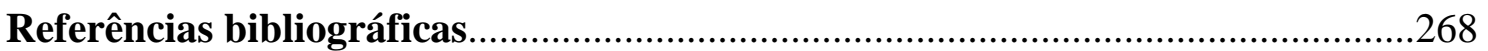




\section{Lista de abreviaturas}

As edições das obras de Merleau-Ponty citadas nesta tese e as respectivas siglas pelas quais a elas nos referimos são as seguintes ${ }^{1}$ :

Merleau-Ponty, M. Humanisme et Terreur. Paris: Gallimard, 1947. (HT) . La Nature. Notes. Cours du Collège de France. Paris: Seuil, 1995. (N) . La Prose du Monde. Paris: Gallimard, col. Tel, 1999. (PM) . La Structure du Comportement. Paris: PUF, col. Quadriges, 2002. (SC)

. Le Primat de la Perception et ses Conséquences Philosophiques. Lagrasse: Verdier, 1992. (PP) . Le Visible et le Invisible. Paris: Gallimard, col. Tel, 2001. (VI) ${ }^{2}$ . Les Aventures de la Dialectique. Paris: Gallimard, folio essais, 2000. (AD) - L'Institution. La Passivité. Notes de Cours au Collège de France 19541955. Paris: Belin, 2003. (IP)

. L'Oeil et l'Esprit. Paris: Gallimard, col. Folio/ essais, 1999. (OE)

. Notes de Cours 1959-1961. Paris: Gallimard, 1996.

$\overline{1998 .(\mathrm{OG})}$ - Notes de Cours sur l'Origine de la Géométrie de Husserl. Paris: PUF, . Parcours II. Lagrasse: Verdier, 2000. (PII)

. Phénoménologie de la Perception. Paris: Gallimard, col. Tel, 1997. (PhP)

- Psychologie et Pédagogie de l'Enfant. Cours de Sorbonne 1949-1952. Lagrasse : Verdier, 2001. (PPE)

. Résumés de Cours. Collège de France 1952-1960. Paris: Gallimard, 1968. (RC) . Sens et non Sens. Paris : Gallimard, 1997. (SnS) . Signes. Paris: Gallimard, 1998. (S)

\footnotetext{
${ }^{1}$ Os dados de outros dois textos menores de Merleau-Ponty se encontram nas referências bibliográficas. 2 A fim de facilitar o reconhecimento das notas de trabalho incluídas no final desse livro, acrescentaremos sua data após a paginação (por exemplo, VI, 322, março 1961).
} 


\section{Introdução}

Neste trabalho, analisamos como a problemática ontológica se desenvolve no decorrer da obra de Merleau-Ponty. Defenderemos que já em suas teses de doutoramento (A Estrutura do Comportamento, publicada em 1942, e Fenomenologia da Percepção, publicada em 1945), há uma doutrina ontológica em vigor (fortemente marcada por uma inspiração fenomenológica), a qual, posteriormente reconhecida como insuficiente pelo próprio autor, será modificada nas obras finais. O percurso geral de nosso trabalho será acompanhar não só a exposição dessa primeira doutrina ontológica e de suas dificuldades, mas também a subseqüente elaboração de uma nova ontologia. $\mathrm{O}$ foco central de nossa tese será, assim, esclarecer as concepções de ser fornecidas por Merleau-Ponty em seu itinerário filosófico. O estudo desse itinerário supõe, de nossa parte, ao menos dois princípios metodológicos: em primeiro lugar, não se tratará de resumir as diversas obras de Merleau-Ponty, mas sim de selecionar e avaliar criticamente somente as discussões do autor acerca do problema ontológico. Em segundo lugar, não assumiremos nenhum esquema prévio acerca de diferentes fases do pensamento de Merleau-Ponty. Seguiremos a ordem cronológica em que seu pensamento se desenvolveu, a fim de exibir a persistência de certos temas e a maturação de outros, sem a preocupação de justificar qualquer esquema genérico de interpretação da sua obra ${ }^{1}$.

Apesar de aparentemente banal, o percurso por nós escolhido revela o seu caráter de hipótese de trabalho se confrontado com a posição de alguns dos maiores comentadores da obra de Merleau-Ponty. Em De l'Être du Phénomène. Sur l'ontologie de Merleau-Ponty ${ }^{2}$, Renaud Barbaras defende que a ontologia do autor estudado só se consolida verdadeiramente em $O$ Visível e o Invisível, de maneira que "os textos que a precedem não nos parecem dever ser evocados senão como o caminho que até lá conduziram". Para Barbaras, "parece que é à luz de $O$ Visível e o Invisível que os trabalhos anteriores adquirem coerência e consistência, de tal modo que nós não podemos lê-los senão por meio da retomada a qual finalmente eles propiciam"4. O

\footnotetext{
1 Aproximamo-nos, assim, da postura metodológica assumida por G. B. Madison (Cf. The Phenomenology of Merleau-Ponty. A search for the limits of consciousness. Athens: Ohio Univ. Press, 1981, p. xxviii). No entanto, quanto à interpretação dos textos de Merleau-Ponty, divergimos de Madison em vários pontos, conforme ficará claro no decorrer deste trabalho.

${ }^{2}$ Grenoble: Jérôme Millon, 2001.

${ }^{3}$ Barbaras, R. op. cit., p. 12 .

${ }^{4} I d .$, ibid.
} 
pensamento de Merleau-Ponty seria "profundamente uno", mas essa unidade implica somente que $O$ Visível $e$ o Invisível recolhe "tudo o que havia sido pensado antes"6 numa nova estrutura, de maneira que a Fenomenologia da Percepção deve ser considerada somente como "um trabalho preliminar"7, o qual anuncia uma problemática ontológica que escapa de seus limites ${ }^{8}$.

Por sua vez, em Merleau-Ponty's Ontology ${ }^{9}$, M. C. Dillon defende que o filósofo francês, no decorrer de sua obra, nada faz senão explicitar teses ontológicas prefiguradas na Fenomenologia da Percepção: "eu argumentarei que, longe de uma virada ou ruptura na continuidade do pensamento de Merleau-Ponty, há um desenvolvimento consistente de um ponto de vista unitário"10. Dillon reconhece haver diferenças terminológicas importantes entre a Fenomenologia da Percepção e $O$ Visível e o Invisível, mas nada que implique algum acréscimo teórico que não esteja de alguma forma subentendido já nas primeiras obras de Merleau-Ponty ${ }^{11}$. Assim, segundo essa interpretação, os principais temas ontológicos tratados por Merleau-Ponty se encontram antecipados na Fenomenologia da Percepção, a qual não se reduziria a uma obra preliminar a ser superada pela ontologia madura, pois já conteria as teses mais marcantes dessa última ${ }^{12}$.

Estamos diante de uma divergência marcante. Por um lado, defende-se que a problemática ontológica está praticamente ausente das primeiras obras de MerleauPonty, e, por outro, defende-se que ela está praticamente incluída nessas primeiras obras. Daí que a tese assumida por nós não seja óbvia, mas implique uma interpretação do itinerário filosófico de Merleau-Ponty. Trata-se de uma interpretação média em relação às duas posturas citadas acima: reconhecemos que há uma doutrina ontológica autônoma na Fenomenologia da Percepção (conforme será exposto em nosso primeiro capítulo), embora também admitamos que essa não será a sua doutrina ontológica final, já que modificações importantes ocorrerão (conforme mostramos nos demais capítulos).

\footnotetext{
${ }^{5}$ Id., ibid.

${ }^{6}$ Id, ibid..

${ }^{7}$ Id., ibid.

8 Madison também partilha da tese de que não há uma reflexão ontológica desenvolvida na Fenomenologia da Percepção (Cf. Madison, op. cit. p.36, 183). Vale mencionar que em textos posteriores, Barbaras considera haver aspectos ontológicos relevantes já na Fenomenologia da Percepção (Cf. Barbaras, R. Le Tournant de l'Expérience.Recherches sur la philosophie de Merleau-Ponty. Paris: Vrin, 1998, p.183).

${ }^{9}$ Evanston: Northwestern Univ. Press, 1997.

${ }^{10}$ Dillon, op. cit., p.154.

${ }^{11}$ Cf. Dillon, op. cit., p.85.

${ }^{12}$ H. Pietersma (em seu livro Phenomenological Epistemology. Oxford: Oxford Univ. Press, 2002) defende uma interpretação semelhante, a qual avaliaremos em nossa conclusão.
} 
Para tornar mais claras as especificidades de nossa interpretação, continuaremos a delineá-la por contraste com alguns dos mais significativos comentários recentes da obra de Merleau-Ponty.

Quanto ao reconhecimento de uma ontologia já nos primeiros textos do filósofo francês, aproximamo-nos do livro Razão e Experiência. Ensaio sobre Merleau-Ponty ${ }^{13}$, de Luiz Damon S. Moutinho. Esse autor defende que a perspectiva de renovação das categorias ontológicas por meio de uma abordagem indireta (tema típico dos cursos de Merleau-Ponty sobre a natureza, nos anos cinquienta) já se encontra nas teses de doutoramento do filósofo. As análises contidas em A Estrutura do Comportamento acerca da Gestalttheorie e das possíveis aplicações da noção de forma na física, biologia e psicologia mostrariam "que a própria ciência já ultrapassou os quadros da ontologia clássica, que o ser visado por ela não é o ser em si, objetividade e exterioridade puras, e justamente por isso ela nos convida a redefinir a ontologia"14. Assim, já no primeiro livro de Merleau-Ponty, o problema do ser seria abordado em decorrência de uma reflexão acerca de um ente delimitado pela ciência (a Gestalt). Segundo Damon, o ser entrevisto pelas pesquisas científicas "é de ordem perceptiva"15, e exige uma descrição dos fenômenos percebidos para sua devida explicitação. Assim, na Fenomenologia da Percepção Merleau-Ponty utilizaria o instrumental fenomenológico para completar uma renovação ontológica já anunciada em seu primeiro livro. Nós concordamos com esse movimento argumentativo exposto por Damon, o qual retomamos no primeiro capítulo desse trabalho. Mas, em seguida, nosso percurso diverge daquele percorrido por esse autor. Em seu livro, Damon expõe minuciosamente os principais temas da Fenomenologia da Percepção; de nossa parte, concentramo-nos na doutrina ontológica contida nesse livro, da qual tentamos expor algumas conseqüências problemáticas, que teriam levado Merleau-Ponty a reformular, em suas obras finais, sua posição filosófica. Infelizmente Damon não analisa em detalhe os textos finais de Merleau-Ponty e não se posiciona, assim, em relação a tais modificações no seu itinerário.

Quanto à análise dessas mudanças, aproximamo-nos de duas leituras. A primeira delas é formulada por Emmanuel de Saint Aubert no livro Vers une Ontologie Indirecte. Sources et enjeux critiques de l'appel à l'ontologie chez Merleau-Ponty ${ }^{16}$. Tal como Damon, esse autor também defende que já há uma teorização ontológica nas primeiras

\footnotetext{
${ }^{13}$ São Paulo: Unesp/Fapesp, 2006.

${ }^{14}$ Moutinho, op. cit., p.45.

${ }^{15}$ Ibid., p.24.

${ }^{16}$ Paris: Vrin, 2006.
} 
obras de Merleau-Ponty, nas quais a investigação fenomenológica da percepção almejava desvelar um modo primordial de acesso ao ser do mundo, modo que fundaria todos os demais ${ }^{17}$. Por sua vez, Saint Aubert reconhece que as intenções ontológicas contidas na Fenomenologia da Percepção são reelaboradas ante as insuficiências reconhecidas por vários críticos do projeto de Merleau-Ponty, e posteriormente admitidas pelo próprio filósofo ${ }^{18}$. No entanto, parece-nos que Saint Aubert não menciona claramente quais as mudanças introduzidas por Merleau-Ponty para suprir as insuficiências de sua ontologia fenomenológica e, por vezes, dá a impressão de que a ontologia final incorpora as principais teses da Fenomenologia da Percepção, como se fosse meramente requerida por essa última para realizar todas as suas intenções ${ }^{19}$. De nossa parte, concordamos com o quadro geral apresentado por Saint Aubert (havia um projeto ontológico na Fenomenologia da Percepção que foi longamente aperfeiçoado posteriormente); porém, defenderemos que a formulação da ontologia final de MerleauPonty implicará o rompimento com a concepção de ser em vigor em seus livros iniciais.

A segunda leitura que reconhece modificações no itinerário ontológico de Merleau-Ponty é formulada por Étienne Bimbenet em Nature et Humanité. Le problème anthropologique dans l'oeuvre de Merleau-Ponty ${ }^{20}$. Esse autor expõe as tentativas pelas quais Merleau-Ponty tenta superar a cisão entre mundo natural e subjetividade. Sua tese é que "o ultrapassamento da antinomia entre natureza e consciência só pode se operar no seio de uma ontologia conseqüente, para a qual a natureza não seria o outro do espírito, nem o espírito o outro da natureza" ${ }^{, 21}$. Tal ontologia conseqüente seria desenvolvida somente nos textos finais do filósofo, já que em A Estrutura do Comportamento e na Fenomenologia da Percepção a integração entre natureza e consciência ocorreria de forma assimétrica, em favor da última. Em A Estrutura do Comportamento, Merleau-Ponty consideraria as estruturas físicas e vitais como objetos da percepção (Gestalten), e, desse modo, já apresentaria "a natureza material como um tipo de significação ordenada segundo a consciência"22. Além disso, nessa obra, a inserção da consciência na natureza se limitaria ao reconhecimento de uma história longínqua da qual a primeira teria sido derivada (estruturação do mundo físico, estruturação da vida sobre esse mundo e, finalmente, estruturação da consciência sobre

\footnotetext{
${ }^{17}$ Cf. Saint Aubert, op. cit., p.18, 148, 202.

${ }^{18}$ Cf. Ibid., p.24, 260.

${ }^{19}$ Cf. Ibid., p.17.

${ }^{20}$ Paris: Vrin, 2004.

${ }^{21}$ Bimbenet, op. cit., p. 31 .

${ }^{22}$ Ibid., p.82.
} 
a vida), e da possibilidade de desintegração dos comportamentos elevados (nas patologias, por exemplo, os sujeitos se reduzem a estereotipias biológicas). Quer dizer que por "natureza" somente se circunscreveria situações-limite exteriores à consciência, ao espectador dos fenômenos ${ }^{23}$. Já na Fenomenologia da Percepção, a natureza seria associada à vida irrefletida do corpo, sustentáculo íntimo da consciência e não mais, como em sua obra anterior, a uma região de contingência em que a consciência poderia decair. Mesmo assim, no livro de 1945, Merleau-Ponty teria submetido a vida irrefletida "à regra de uma coerência intrínseca" 24 , de maneira a racionalizar a natureza corporal em que a consciência estaria inscrita. Essa delimitação racional da natureza tornar-se-ia patente no tratamento da experiência da coisa, em que Merleau-Ponty supõe uma tal conivência ontológica entre sujeito e mundo que "a coisa recebe um modo de ser que é exatamente aquele do corpo" 25 . Bimbenet reconhece que, segundo Merleau-Ponty, a coisa não é um correlato corporal e repousa em si no mundo natural, tese baseada na premissa de que "o meio atual e atualmente centrado sobre nosso corpo se encontra repentinamente descentrado em direção a um meio virtualmente participável por todo

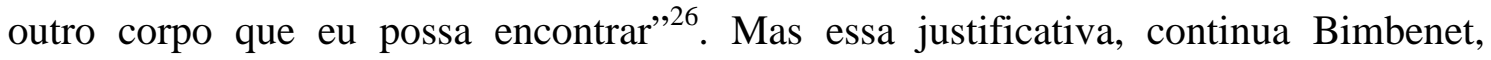
somente assume a suposição racional de que o espetáculo percebido pode ser partilhável por todos os sujeitos, e que, dessa maneira, não se reduz a correlato subjetivo de nenhum deles em particular. Para Bimbenet, essa suposição submete a vida irrefletida natural às exigências de concordância e coerência da racionalidade e, no geral, favorece as estruturas da consciência, mesmo se o projeto da Fenomenologia da Percepção era o de inscrevê-las na natureza irrefletida do corpo e na experiência préobjetiva do mundo.

Segundo Bimbenet, Merleau-Ponty, em seus textos finais, mudaria sua perspectiva filosófica e tentaria mostrar não mais como a natureza se harmoniza com as regras da consciência racional, mas como as capacidades da consciência surgem do enraizamento do sujeito carnal no mundo. "Não é mais então o espírito que sublima nossa natureza corporal e a faz servir aos seus fins, é nossa natureza corporal que pode, adequadamente dar conta do advento do espírito"27. Decorreria dessa perspectiva a idéia, proposta por Merleau-Ponty em seus textos finais, de um ser carnal anterior à

\footnotetext{
${ }^{23}$ Cf. Ibid., p.92-3, 102, 106-7.

${ }^{24}$ Ibid., p.109.

${ }^{25}$ Ibid., p. 175 .

${ }^{26}$ Ibid., p.197.

${ }^{27}$ Ibid., p.264.
} 
distinção entre sujeito e objeto, ser que permitira atestar a pertença sensível do sujeito ao mundo.

Concordamos com a leitura de Bimbenet, a qual permite finalmente circunscrever de maneira mais clara as mudanças no itinerário filosófico de MerleauPonty. Nossa tese, ao tentar expor tais mudanças, proporá uma análise paralela àquela fornecida por Bimbenet. Nós não focaremos o problema das relações entre natureza e consciência, tal como faz esse autor, mas sim aquele da concepção de ser no decorrer da obra de Merleau-Ponty. Mas os dois problemas estão intimamente ligados e a análise de Bimbenet oferece a ocasião para elucidar nossa própria tese. Segundo Bimbenet, as análises iniciais de Merleau-Ponty sobre as relações entre natureza e consciência padeciam de intelectualismo, uma vez que a natureza era assimilada a um horizonte de racionalidade projetado sobre a experiência ${ }^{28}$. Já quanto à concepção de ser, defenderemos que tais análises padecem de idealismo, pois o ser do mundo é ali delimitado conforme o que as capacidades perceptivas podem apreender. Por sua vez, as reflexões finais de Merleau-Ponty acerca de uma natureza primordial de onde brotaria a própria consciência, tal como aponta Bimbenet, implicam a formulação de uma noção ampliada de ser, não mais limitada àquilo que as capacidades perceptivas conseguem assimilar do mundo, mas ser que funda e envolve a própria consciência.

Delimitamos, assim, em paralelo ao estudo de Bimbenet, o escopo geral de nosso estudo acerca do problema do ser em Merleau-Ponty. Cabe agora esclarecer de que maneira ordenaremos a análise desse problema em nossa tese. Trata-se, no primeiro capítulo, de explicitar o projeto ontológico contido nas teses de doutoramento de Merleau-Ponty, o qual, segundo nossa leitura, se comprometerá com conseqüências idealistas inaceitáveis para o próprio autor. Nos capítulos seguintes, acompanharemos como Merleau-Ponty, no decorrer dos anos cinqüenta, esboça uma nova concepção ontológica, a qual, sem reatar com nenhum tipo de objetivismo realista, superará as dificuldades idealistas iniciais. No segundo capítulo, consideraremos de que modo as análises de Merleau-Ponty sobre a linguagem contribuem para sua reflexão ontológica. No terceiro, exporemos os ganhos teóricos que seus cursos sobre a instituição, a passividade e a natureza fornecem para a formulação de uma nova concepção de ser. No quarto, explicitaremos o procedimento metodológico utilizado por Merleau-Ponty nesses cursos e buscaremos expor como a análise das ciências e das artes em geral

\footnotetext{
${ }^{28}$ Cf. Ibid., 229, 264.
} 
contribui para a descrição do ser. No quinto, consideraremos em que medida essas investigações ontológicas tardias de Merleau-Ponty se afastam da perspectiva fenomenológica adotada em suas obras iniciais. Por fim, no sexto capítulo e na conclusão, exporemos as linhas gerais da ontologia final de Merleau-Ponty em contraste com sua ontologia fenomenológica inicial.

Parece-nos que ao expor essa concepção final de Merleau-Ponty, oferecemos uma contribuição interpretativa pouco notada pelos comentadores em geral. Defenderemos que a última concepção do ser esboçada por Merleau-Ponty admite um excesso ontológico em relação àquilo que se fenomenaliza para as capacidades perceptivas, e que, dessa maneira, o ser bruto apresentado pelas obras finais do filósofo não está em uma correlação de direito perfeita com os poderes perceptivos e motores da subjetividade encarnada, tal como parece ocorrer na Fenomenologia da Percepção. Alguns comentadores, aqueles que admitem uma harmoniosa continuidade entre a Fenomenologia da Percepção e O Visível e o Invisível (Dillon e Pietersma, por exemplo), nem mesmo admitem haver um problema como aquele do excesso do ser em relação às habilidades perceptivas, já que eles assumem (erroneamente, a nosso ver) que o ser exposto nas obras finais de Merleau-Ponty não é senão uma explicitação do mundo percebido tal como apresentado pelo livro de 1945. Já os comentadores que ao menos reconhecem o caráter problemático do tema da amplitude do ser em relação às capacidades perceptivas hesitam em relação a esse ponto. Como veremos em nossa conclusão, Barbaras, Madison e Franck Robert ${ }^{29}$ chegam a reconhecer um excesso do ser em relação ao que é percebido, mas também sustentam que uma característica essencial do ser é fenomenalizar-se, de maneira que o que é acaba se confundindo com o que aparece. De nossa parte, vemos aqui uma simplificação da análise ontológica final de Merleau-Ponty, a qual embora reconheça um ser sensível que prepara do seu interior sua fenomenalização (tema tratado com a noção de carne), investiga camadas ou dimensões ontológicas negativas ou invisíveis (das quais só temos acesso direto à sua ausência). Pretendemos explicitar, em nossa conclusão, esse duplo aspecto contido na análise ontológica final de Merleau-Ponty, o qual parece pouco compreendido pelos comentadores.

Também nos interessa avaliar criticamente os resultados ontológicos obtidos por Merleau-Ponty. Em nossa conclusão, discutiremos uma suspeita levantada por

\footnotetext{
${ }^{29}$ Quanto a esse último autor, referimo-nos a seu livro Phénoménologie et Ontologie. Merleau-Ponty lecteur de Husserl et Heidegger. Paris: L’Hamarttan, 2005.
} 
Michel Haar ${ }^{30}$, a saber, se tais resultados podem ser tachados de metafísicos, no sentido das doutrinas metafísicas que, segundo Kant, requeriam uma "crítica". Retomemos aqui, para esclarecer tal suspeita, o que se espera de uma empreitada ontológica. Entendemos por ontologia o estudo das características e estruturas mais gerais da realidade, do ser em geral, estudo que comporta ao menos duas diferentes abordagens ${ }^{31}$. A primeira delas seria a abordagem extensional, ou seja, o exame das classes de objetos, fatos ou situações a que o termo "ser" se aplica. Desse ponto de vista, a investigação ontológica almeja enumerar aquilo que é, e "ser" significará a totalidade de entes que existem. A outra abordagem ao problema ontológico é a intensional. Nesse caso, não se trata de percorrer a extensão de "ser" (a totalidade das coisas que são) para compreender aquilo que o ser é, não se trata de esgotar a enumeração das coisas ou categorias que existem; trata-se, por sua vez, de esclarecer como se define o escopo de tal extensão, ou seja, de esclarecer qual a natureza do ser, quais as características comuns (o modo de ser) por meio das quais todas as coisas que existem compõem a extensão do termo "ser". Importa, nessa abordagem, elucidar qual o sentido de "ser" para então tornar claro porque se diz de certas coisas ou fatos que eles são e de outros que eles não são.

Parece-nos que Merleau-Ponty, no decorrer de toda a sua carreira filosófica, segue essa abordagem intensional. Daí que para ele o trabalho da ontologia não seja o de descobrir fatos ou eventos desconhecidos do mundo, contribuindo, assim, para alargar nossas classificações enumerativas acerca do que há. Em suas investigações ontológicas, Merleau-Ponty se dedica a um esforço de renovação conceitual, de refinamento do aparato linguí́stico pelo qual nos referimos ao mundo e ao ser em geral $^{32}$. Trata-se de criticar o modo pelo qual as categorias herdadas da tradição filosófica nos fazem entender o ser (modo baseado em cisões bastante discutíveis, segundo Merleau-Ponty, tal como aquela entre sujeito e objeto) e de formular

\footnotetext{
${ }^{30}$ Cf. Haar, M. "Proximité et distance vis-à-vis de Heidegger chez le dernier Merleau-Ponty". In: La Philosophie Française entre Phénoménologie et Métaphysique. Paris: PUF, 1999, p.9-34.

${ }^{31}$ Cf. Priest, S. Merleau-Ponty. London: Routledge, 1998, cap. XIV - Being.

${ }^{32}$ Importa, assim, oferecer definições das características ou propriedades gerais por meio das quais se diz que as coisas ou eventos são. Deve-se notar que embora Merleau-Ponty utilize as estruturas proposicionais consagradas para o conhecimento dos entes particulares (S é $\mathrm{P}$ ) ao afirmar, por exemplo, que o ser é perceptível ou que o ser implica um excesso em relação aos fenômenos, etc., o filósofo não pretende qualificar nenhum ente em particular, mas sim o modo pelo qual as coisas e eventos mundanos existem. Trata-se, desse modo, de tomar o ser figurativamente como objeto de um discurso moldado para tratar dos entes, algo que efetivamente jamais ocorre, pois o ser não é nenhum objeto, e sim o princípio ou estrutura comum a todos os entes. Uma outra estratégia lingüística para a análise ontológica é desenvolver um discurso que em sua própria forma (e não somente pelo seu conteúdo proposicional) explicite o modo como o ser é. Em nosso sexto capítulo, comentaremos como Merleau-Ponty também se serve dessa estratégia em sua obra tardia.
} 
filosoficamente certas categorias pelas quais se estabelecerá uma nova compreensão do sentido do ser do mundo e do sujeito $^{33}$. São os resultados desse esforço de aperfeiçoamento conceitual da compreensão do ser que, segundo Haar, reproduziriam alguns vícios das empreitadas metafísicas clássicas. Haar entende por metafísica um modo particular pelo qual historicamente a investigação ontológica se realizou, modo que tomaria indevidamente certos aspectos ônticos como o próprio ser em geral $^{34}$. Cumpre avaliar se a ontologia de Merleau-Ponty partilha desse modo e, assim, recai em impasses teóricos já tradicionalmente conhecidos, ou se realmente forja instrumentos conceituais para renovar o problema do ser.

33 “A ontologia seria a elaboração das noções que devem substituir aquela de subjetividade transcendental, aquelas de sujeito, objeto, sentido" (VI, 219, jan. 1959).

${ }^{34}$ Além disso, as metafísicas clássicas concebiam o ser como realidade supra-sensível e causa primeira das aparências fenomênicas. 


\section{Capítulo I - Os impasses da ontologia fenomenológica de Merleau-Ponty}

\section{Sinopse}

De início, retomamos o projeto filosófico contido nas duas primeiras obras de Merleau-Ponty e em seguida analisamos algumas das críticas endereçadas a ele. Avaliamos que a crítica de que Merleau-Ponty correria o risco de se limitar a conclusões de cunho psicológico pode ser superada no quadro da própria Fenomenologia da Percepção. Porém, defendemos que a crítica de que Merleau-Ponty se compromete com conseqüências idealistas ${ }^{1}$ é correta e que tais conseqüências se originam de um uso heterodoxo do tema do a priori da correlação, herdado de Husserl. Por fim, esboçamos o desenvolvimento ulterior da ontologia de Merleau-Ponty, o qual conjuga a reformulação de algumas teses da Fenomenologia da Percepção com uma análise da cultura contemporânea.

\section{A) As primeiras obras de Merleau-Ponty}

\section{A Estrutura do Comportamento}

A tarefa geral do primeiro livro de Merleau-Ponty é reformular as relações entre natureza e consciência por meio da noção de comportamento. A fim de tornar clara essa estratégia, responderemos a duas questões: 1) por que as relações entre a natureza e a consciência devem ser reformuladas? 2) Como a noção de comportamento permite renovar o entendimento das relações entre esses dois termos?

1) Merleau-Ponty julga insuficientes as abordagens clássicas das relações entre natureza e consciência. Essas abordagens são o pensamento neokantiano e o pensamento causal, doutrinas filosóficas pressupostas por algumas teorias científicas. Daí que os dois primeiros capítulos de A Estrutura do Comportamento acompanhem o embate entre diferentes teorias psicológicas: ao discutir as limitações e virtudes dessas doutrinas científicas, também se elucidam, indiretamente, os problemas das concepções filosóficas sobre as quais tais doutrinas se baseiam.

Retomemos rapidamente a descrição das concepções clássicas contida em $A$ Estrutura do Comportamento. Para Merleau-Ponty, o pensamento neokantiano se caracteriza por conceber a natureza como um conjunto de propriedades e relações

\footnotetext{
${ }^{1}$ Usamos o termo "idealismo" para caracterizar a posição filosófica que concebe o ser como aquilo que pode ser apreendido pela percepção. Nesse sentido, o idealismo não defende que o ser é apenas uma projeção do pensamento humano sem nenhuma subsistência, uma ilusão, mas sim que a maneira pela qual as coisas e eventos são se restringe ao que pode ser captado pela percepção humana.
} 
objetivas constituídas pela consciência cognitiva. A física, julga Merleau-Ponty, é a ciência que mais assimila a tese neokantiana, dada a aparente volatização da realidade segundo o modelo científico adotado (por exemplo, segundo um modelo físico mecânico, a realidade aparece como conjunto de partículas em movimento; segundo um modelo dinâmico, como um conjunto de forças em interação). Já o pensamento causal, presente, segundo Merleau-Ponty, principalmente na biologia e na psicologia, privilegia as relações de determinação entre ordens de eventos reais (por exemplo, a ordem psicológica se constituiria como efeito da fisiológica, o comportamento seria efeito das pressões do meio) (Cf. SC, 1-2).

As duas abordagens filosóficas expostas acima defendem teses diferentes acerca das relações entre natureza e consciência. Para o neokantismo, a natureza recebe seu caráter objetivo dos poderes sintéticos da consciência cognitiva, concebida como uma entidade pura, ou seja, independente da teia de eventos empíricos (teia que justamente seria organizada segundo os parâmetros cognitivos da consciência). Por sua vez, para o pensamento causal, a natureza consiste em um conjunto de eventos reais em mútua determinação conforme leis próprias. Segundo essa perspectiva, a consciência se reduz a um ente no interior desse conjunto, e pode ser considerada efeito de eventos físicos e/ou fisiológicos (conforme uma abordagem materialista) ou uma força vital/espiritual autônoma (conforme uma abordagem vitalista).

Merleau-Ponty considera insuficientes essas teses decorrentes das concepções clássicas em pauta. Para justificar tal juízo, o filósofo analisa algumas teorias científicas e tenta mostrar como as concepções filosóficas em questão comprometem os resultados obtidos pelas primeiras. Os dois capítulos iniciais de A Estrutura do Comportamento examinam o pensamento causal, transformado em método pela biologia e pela psicologia reducionistas (as quais pretendem explicar o comportamento animal e humano com base em relações de determinação causal ${ }^{2}$ ). Para Merleau-Ponty, esse programa reducionista fracassa, pois, como a escola psicológica Gestalttheorie pretende ter mostrado, há fenômenos que não se resumem à interação causal de elementos exteriores entre si. Uma melodia, por exemplo, mesmo transportada para um tom que não partilha nenhum dos sons primitivos, ainda pode ser reconhecida como tal. Isso ocorre porque, segundo a Gestaltheorie, existe uma forma geral (Gestalt) cujas propriedades excedem aquelas dos componentes isolados da melodia.

\footnotetext{
${ }^{2}$ Merleau-Ponty avalia principalmente o projeto pavloviano de explicar tanto o comportamento inferior (animal) quanto o superior (humano) por meio da doutrina do reflexo condicionado (Cf. SC, 55-60).
} 
Essa noção de forma fomenta uma explicação alternativa da interação entre organismo e meio. Muitos experimentos dos gestaltistas pretendem provar que os seres vivos não reagem automaticamente a estímulos isolados, mas que tais estímulos recebem seu sentido em relação a uma forma pela qual o organismo apreende a situação vivida, assim como cada nota realiza sua função em relação ao todo de uma melodia (Cf. SC, 62). Essas formas, padrões de distribuição dos estímulos perceptivos, exprimem as estruturas biológicas pelas quais os organismos delimitam um meio significativo para sua sobrevivência. Por exemplo, dado que certos organismos dispõem de uma estrutura visual preponderante (e. g., corujas, gatos), determinadas formas visuais estáveis são privilegiadas em seu comportamento. Do mesmo modo, organismos com uma estrutura auditiva proeminente (e. g., morcegos, lebres) privilegiam as Gestalten auditivas, e assim por diante ${ }^{3}$. Essa delimitação de um meio significativo conforme as estruturas do organismo se antecipa à determinação causal das reações comportamentais por estímulos objetivos. É porque os organismos existem por meio de certas estruturas corporais típicas, as quais definem a amplitude de um determinado campo fenomenal, que certos estímulos podem então figurar significativamente. Assim, é verdade que os organismos reagem a estímulos do meio ambiente, tal como sustenta o pensamento causal. Porém, tais estímulos devem ser compatíveis com as estruturas pelas quais os organismos se inserem no mundo para que possam motivar alguma reação. Dado que o pensamento causal ignora a delimitação, por meio dessas estruturas, do campo geral de atuação do organismo, tal doutrina é ineficaz, conclui MerleauPonty, no estudo do comportamento.

A assimilação dos estímulos conforme os padrões estruturais dos organismos não deve ser confundida com a constituição da natureza pelas sínteses cognitivas da pura consciência (tese do neokantismo). Na verdade, tal assimilação, sustenta MerleauPonty, consiste em um processo coordenado pelas capacidades perceptivas, as quais apresentam diretamente os entes e os eventos existentes no mundo (Cf. SC, 227). A percepção não se limita a forjar representações sobre um mundo que em si mesmo poderia divergir daquilo que é apreendido. O sentido dos fenômenos apreendidos é aderente aos eventos materiais apresentados. Assim, as Gestalten percebidas não são somente unidades de significação constituídas subjetivamente, mas manifestações fenomênicas que desvelam diretamente os eventos mundanos. Desse modo, a noção de

\footnotetext{
${ }^{3}$ Sobre a distinção entre forma e estrutura e a remissão da primeira à ultima, de modo a Merleau-Ponty fundar a teoria da percepção sobre uma filosofia do organismo, ver Bimbenet, E. Op. cit., 2004, p. 53-55.
} 
Gestalt unifica significação e existência: por meio do arranjo fenomenal percebido, manifesta-se um sentido que não se reduz a uma mera construção subjetiva, mas que é inerente ao meio percebido ${ }^{4}$. Por sua vez, o pensamento neokantiano repugna essa unificação, pois tal escola, segundo a interpretação de Merleau-Ponty, nega o contato da consciência cognitiva com a realidade concreta. A consciência se relacionaria, conforme tal escola, apenas com fenômenos constituídos segundo as regras a priori do pensamento, sem assimilar diretamente as coisas e eventos tomados em si mesmos (Cf. SC, 224). Dessa maneira, tal como ocorrera com o pensamento causal, o pensamento neokantiano falha em abranger a complexidade do comportamento entendido por meio da noção de Gestalt.

2) Passemos agora à segunda questão posta inicialmente (como a noção de comportamento renova o entendimento das relações entre natureza e consciência?). Para a Gestaltheorie, o comportamento instaura um campo de formas percebidas por meio do qual os eventos e coisas exteriores são apreendidos. Segundo Merleau-Ponty, o estudo desse campo sugere um novo entendimento das relações entre natureza e consciência: a natureza não se reduz a um conjunto de fenômenos cuja objetividade decorre da atividade cognitiva; ela se apresenta como estímulos concretos reunidos em formas significativas. E como essas formas remetem, em última instância, às potencialidades estruturais dos organismos, a natureza não se exibe como uma ordem de eventos determinantes da consciência, mas sim como uma camada de fatos sensíveis, cuja organização é homogênea em relação às formas derivadas das estruturas perceptivas dos organismos ${ }^{5}$. Por sua vez, a consciência não se confunde com uma pura subjetividade constituinte ou com uma somatória de estados gerados pelo meio ambiente; ela existe, em sua forma originária, como abertura perceptiva, a qual apreende os fatos sensíveis de que a natureza se compõe (Cf. SC, 238-9).

Como vemos, entre natureza e consciência passa a vigorar um tipo de correlação perceptiva. Admite-se o contato da consciência com a natureza concreta (e não apenas com a objetividade construída por meio das categorias cognitivas, tal como defende o pensamento neokantiano) sem, no entanto, reduzir esse contato a determinações causais (conforme o pensamento causal sustenta). Tais determinações são secundárias ante a

\footnotetext{
4 “'O que há de profundo na 'Gestalt' (...) não é a idéia de significação, mas aquela de estrutura, de junção de uma idéia e de uma existência indiscerníveis, o arranjo contingente pelo qual os materiais se põem diante de nós a ter sentido, a inteligibilidade em estado nascente" (SC, 223).

${ }^{5}$ Essa concepção da natureza será mantida na Fenomenologia da Percepção: "há uma natureza, não aquela das ciências, mas aquela que a percepção me mostra” (PhP, 494).
} 
apresentação da natureza como conjunto de eventos organizados em conformidade com as estruturas perceptivas. No terceiro capítulo de A Estrutura do Comportamento, Merleau-Ponty compreende as três ordens constituintes do universo (física, vital e humana) como diferentes formas (quer dizer, como estruturas concretas ordenadas conforme parâmetros perceptivos), e não como conjuntos de eventos constituídos pela consciência ou como séries de fenômenos autônomos que se relacionariam entre si de maneira causal ${ }^{6}$. Essa aplicação da correlação perceptiva para todos os domínios do universo implica uma nova filosofia transcendental (Cf. SC, 215), ou seja, uma renovação da doutrina que considera as estruturas subjetivas como condição da organização da experiência.

O transcendentalismo de Merleau-Ponty dispensa um puro sujeito cognitivo e acentua que a natureza deve ser compreendida como reunião de Gestalten com um sentido inerente aos seus componentes materiais, sentido que é exatamente aquele apreendido pela consciência perceptiva. Deve-se notar que a consciência perceptiva que Merleau-Ponty tem em vista é aquela humana. É verdade que todas as espécies animais instauram, em sua relação com o meio, padrões gestálticos próprios. Isso poderia sugerir uma multiplicidade de padrões transcendentais de ordenação da experiência. No entanto, Merleau-Ponty acentua o fato de que a inserção das diversas espécies no meio ambiente consiste em um evento perceptível para o cientista que estuda o comportamento. Assim, o filósofo francês considera os processos vitais dos organismos, bem como os fenômenos físicos no geral, como diferentes estruturas que se manifestam para a consciência humana ${ }^{7}$. Em sua própria organização interna, crê Merleau-Ponty, os fenômenos físicos e vitais supõem uma manifestação para a percepção humana, e, nesse sentido, essa última exerce o papel de instância transcendental última pela qual a organização de toda a experiência se torna compreensível ${ }^{8}$.

\footnotetext{
${ }^{6}$ Merleau-Ponty espera que "aplicável igualmente aos três campos que acabam de ser definidos, [a noção de forma] os integraria como três tipos de estruturas, ultrapassando as antinomias do materialismo e do espiritualismo, do materialismo e do vitalismo" (SC, 141). A forma alimenta uma caracterização do ser da natureza nem materialista nem espiritualista ou vitalista. Desse modo, a Gestalt fomenta uma reforma das noções básicas da ontologia.

${ }^{7}$ Segundo Merleau-Ponty, cada organismo "é um conjunto significativo para uma consciência que o conhece, não uma coisa que repousa em si" (SC, 172). Mais à frente, afirma: "nossa experiência externa é aquela de uma multiplicidade de estruturas, de conjuntos significativos. Uns, que constituirão o mundo físico, encontram em uma lei matemática a expressão suficiente da sua unidade interior. Outras, chamadas de seres vivos, oferecem a particularidade de ter um comportamento" (SC, 172-3).

${ }^{8}$ Daí Merleau-Ponty afirmar que "o que chamamos natureza é já consciência da natureza, o que chamamos vida é já consciência da vida e o que chamamos psiquismo é ainda um objeto diante da consciência" (SC, 199).
} 
Conforme vimos há pouco, a percepção das Gestalten não é uma mera projeção subjetiva; há uma interação entre capacidades perceptivas e materiais sensíveis de modo que o sujeito perceptivo apreende um sentido já esboçado na ordenação dos próprios eventos do universo. Essa tese implica que o domínio transcendental circunscrito por Merleau-Ponty, contrariamente ao que prega a tradição neokantiana, não se distingue totalmente dos dados empíricos, ou seja, as formas nas quais os fenômenos mundanos se manifestam são aquelas que exprimem um contato efetivo com a natureza percebida. Seria errôneo, segundo essa perspectiva, supor um domínio transcendental autônomo, composto por puras Gestalten humanas, já que tais formas percebidas nada realizam senão apresentar um sentido latente na própria natureza.

Retomemos o exemplo da melodia para comentar a inseparabilidade entre o caráter transcendental das formas perceptivas de manifestação fenomênica e os materiais empíricos sobre os quais tal caráter se exerce: uma melodia é uma forma cujo sentido não se reduz à soma das notas particulares que a compõem, visto que tal forma pode se manter em diferentes tonalidades. A melodia pode ser concebida tal qual uma unidade de significação que atribui funções aos dados sonoros parciais que a compõem, e, nesse sentido, exerceria um "papel transcendental" na organização de uma experiência musical. Mas a melodia não se constitui como uma forma abstrata que subsiste independentemente de quaisquer notas reais; embora a melodia exiba propriedades que excedem aquelas das notas particulares, sua forma geral pressupõe que haja notas numa certa relação. Do mesmo modo, as estruturas perceptivo-motoras humanas não são poderes puros, mas capacidades polarizadas pelas situações mundanas, de modo que o estudo da atividade transcendental do sujeito perceptivo implica considerar sua inserção atual num tecido de fenômenos concretos ${ }^{9}$. Segue-se daí que a análise transcendental esboçada por A Estrutura do Comportamento, e que MerleauPonty desenvolverá em seu segundo livro, não se prestará a descrever condições formais da experiência (tal como sugere a tradição neokantiana), mas se dedicará a explorar as vivências particulares em que os parâmetros perceptivos de organização dos dados são exercidas por um sujeito engajado nas situações mundanas ${ }^{10}$.

\footnotetext{
${ }^{9} \mathrm{Na}$ Fenomenologia da Percepção, Merleau-Ponty afirma que "nós só apreendemos a unidade de nosso corpo naquela da coisa e é com base nas coisas que nossas mãos, nossos olhos, todos nossos órgãos dos sentidos nos aparecem como tantos instrumentos substituíveis" (PhP, 372). Dessa maneira, os sistemas perceptivos do corpo só se revelam como capacidades exploradoras de um meio, capacidades pelas quais o próprio meio adquire seus limites significativos, quando solicitados pelas situações mundanas.

${ }_{10}$ "Seria necessário definir novamente a filosofia transcendental de maneira a nela integrar até o fenômeno do real (SC, 241).
} 


\section{A Fenomenologia da Percepção}

A Estrutura do Comportamento concebe a natureza como um conjunto de estruturas organizadas segundo parâmetros perceptivos. Haveria, assim, um nível em que o mundo (e o universo em geral) se apresentaria não como reunião de objetos e eventos determinados segundo rígidas categorias intelectuais (por exemplo, causalidade, quantidade, medida), mas como um campo organizado segundo uma lógica perceptiva $^{11}$. Essa tese sugere um tipo de redução fenomenológica (cf. SC, 235-6), entendida como suspensão da validade ontológica do mundo objetivo tal como tratado pelas ciências, e explicitação desse nível em que o mundo se manifesta de maneira préobjetiva (conforme os parâmetros da percepção ingênua ou cotidiana). Na Fenomenologia da Percepção, Merleau-Ponty desenvolve essa redução ao defender primeiramente que a camada pré-objetiva de fenômenos é original em relação ao mundo objetivo tratado pelas ciências, ou seja, que os parâmetros de organização de tal camada não seguem as relações objetivas estudadas cientificamente, mas exibem uma inteligibilidade própria ${ }^{12}$. Além disso, Merleau-Ponty defende que a camada préobjetiva é originária em relação ao mundo objetivo, o qual seria, então, um constructo cultural tardio decorrente da experiência pré-objetiva.

Quanto a esse último ponto, Merleau-Ponty sustenta que naturalmente a consciência perceptiva se dirige para coisas autônomas, já que a experiência corporal só adquiriria unidade por meio de um pólo mundano (Cf. nota 6). Desse modo, espontaneamente a consciência perceptiva apresenta seus fenômenos como coisas, como manifestação de um mundo dela independente. As doutrinas objetivistas ignoram que essa manifestação de algum modo depende dos poderes da consciência e tomam o mundo objetivo como anterior e determinante dos resultados percebidos. Por sua vez, Merleau-Ponty defende que não há um ser objetivo puro, mas sim um ser inseparável

\footnotetext{
${ }^{11}$ Merleau-Ponty supõe que a experiência perceptiva não se submete à exatidão das categorias intelectuais objetivas: "nós nos encontramos em presença de um campo de percepção vivida anterior ao número, à medida, ao espaço, à causalidade e que entretanto só se dá como uma visão perspectiva sobre objetos dotados de propriedades estáveis, sobre um mundo e um espaço objetivos" (SC, 235-6). Essa tese é mantida na Fenomenologia da Percepção: "há uma significação do percebido que é sem equivalente no universo do entendimento, um mundo perceptivo que ainda não é o mundo objetivo, um ser perceptivo que ainda não é o ser determinado" (PhP, 58).

${ }^{12}$ Merleau-Ponty dá alguns exemplos da lógica perceptiva pela qual o campo pré-objetivo se organiza: "a força do som sob certas condições faz perder altura, a junção de linhas auxiliares torna diferentes duas figuras objetivamente iguais" (PhP, 14).
} 
das estruturas perceptivas pelas quais tudo se manifesta, ser cujo caráter objetivo é um atributo determinado posteriormente à sua manifestação fenomenal originária ${ }^{13}$.

Uma das principais metas da Fenomenologia da Percepção é descrever esse ser ainda não objetivado e nem puramente subjetivo (no sentido em que uma idéia, uma representação criada cognitivamente o é). Para tanto, Merleau-Ponty desenvolve uma reflexão em três partes. Em primeiro lugar, o filósofo defende que o corpo fenomenal, ou seja, o corpo como agente nas situações mundanas, é um exemplo desse tipo de ser pré-objetivo: o corpo não se reduz a um conjunto de eventos determinados cegamente pelo ambiente, pois dispõe de uma intencionalidade própria, que projeta sobre os estímulos formas típicas de apreender o ambiente (Cf. PhP, 130). Além disso, a atividade corporal não depende de regras cognitivas a priori, uma vez que a intencionalidade do corpo não é representacional (como aquela da consciência), mas um repertório de possibilidades perceptivo-motoras em correlação direta com as situações dadas (Cf. PhP, 169). Dessa maneira, o corpo fenomenal, nem puramente objetivo ou subjetivo, apresenta-se como um terceiro tipo de ser (Cf. $\mathrm{PhP}, 402)$, o qual é originário em relação ao corpo tomado como reunião de órgãos e tecidos, tal qual o estudo da anatomia o considera (Cf. PhP, 403-4).

Em segundo lugar, Merleau-Ponty defende que o mundo percebido também não corresponde às categorias auto-excludentes de sujeito e objeto. $\mathrm{O}$ mundo apresentado pela percepção ingênua não é um conjunto de eventos absolutamente independentes das estruturas perceptivas, mas um campo de situações que se manifestam como Gestalten que a percepção humana pode apreender. Essa tese não reduz o mundo percebido, acredita Merleau-Ponty, a um mero correlato de atos perceptivos, pois o mundo se manifesta como repousando em si próprio, e a organização dos seus eventos, embora se harmonize exatamente com as estruturas do corpo, ocorre nas próprias coisas e situações e não na subjetividade humana (Cf. PhP, 305). Por conseguinte, o mundo percebido não é nem mundo objetivo em-si (cujo ser não seria apreendido diretamente pela percepção) nem mundo para-nós (uma construção subjetiva); ele é em-si-para-nós (Cf. PhP, 372), ou seja, o mundo possui um caráter autônomo (em-si), ao qual a experiência perceptiva tem pleno acesso (para nós) (Cf. PhP, 86). O caráter em-si do mundo, segundo essa perspectiva, não se deve a um conjunto de eventos que não se doa

\footnotetext{
13 “O que me é dado não é somente a coisa, mas a experiência da coisa, uma transcendência em um rastro de subjetividade, uma natureza que transparece através de uma história” (PhP, 376).
} 
para as capacidades perceptivas, mas apenas ao fato de que a ordenação, o sentido e a subsistência de tais eventos não é criada pela atividade subjetiva.

Em terceiro e último lugar, a fim de que as ambigüidades da experiência préobjetiva (tal como aquela do mundo percebido, o qual é ao mesmo tempo em-si e paranós) não se reduzam a uma coletânea de paradoxos, Merleau-Ponty procura desvelar um padrão de racionalidade que fundamente as descrições da atividade corporal e do mundo percebido (Cf. PhP 419). Esse padrão é encontrado na temporalidade, compreendida por Merleau-Ponty como uma estrutura existencial complexa: um fenômeno geral de escoamento, um fluxo indiviso de passagem (tempo constituinte) se realiza como uma multiplicidade de instantes sucessivamente organizados como momentos passados, presentes e futuros (tempo constituído). Entre esses momentos constituídos, Merleau-Ponty acentua o privilégio do presente, descrito como um foco estável por meio do qual os demais instantes podem ser reconhecidos como tais ${ }^{14}$. O filósofo francês se serve da imagem de um jato d'água para esclarecer esse privilégio: o jato tem uma forma que permanece constante devido à sucessão contínua do fluxo de água (Cf. PhP, 482). Da mesma maneira, o fluxo de passagem do tempo sustenta uma forma estável (a consciência presente) em relação à qual diferentes instantes são discernidos (os momentos passados e futuros).

A distinção entre o foco presente (que se confunde com a perspectiva subjetiva consciente) e os demais instantes constituídos (que aparecem como eventos autônomos) permite esclarecer as ambigüidades anteriormente reconhecidas no corpo e no mundo percebido $^{15}$. Segundo Merleau-Ponty, na experiência presente, o mundo se manifesta conforme os parâmetros das estruturas perceptivas, mas sem se reduzir a um correlato subjetivo. Tal irredutibilidade é garantida por uma densidade temporal inerente à manifestação fenomênica: o mundo percebido abarca os instantes passados em que se manifestou e anuncia instantes em que se manifestará, ou seja, se estende para o passado

\footnotetext{
${ }^{14}$ Deve-se notar que Merleau-Ponty não define o presente como um instante pontual, mas como um campo denso, que espontaneamente se abre para o passado e para o futuro. Na verdade, não é possível determinar com exatidão qual a densidade desse campo presente. Para o filósofo, "meu presente é, se se quer, esse instante, mas é também esse dia, esse ano, minha vida inteira" (PhP, 481). Essa falta de precisão quanto aos limites do presente se explica porque "nós consideramos como fazendo parte de nosso presente tudo o que tem uma relação de sentido com nossas ocupações do momento" ( $\mathrm{PhP}, 484$ ).

15 "É pelo tempo que se pensa o ser, pois é pelas relações entre o tempo sujeito e o tempo objeto que se pode compreender aquelas do sujeito e do mundo" (PhP, 492).
} 
e para o futuro, dimensões que excedem a apreensão subjetiva atual das situações mundanas ${ }^{16}$.

A temporalidade, sustenta Merleau-Ponty, também esclarece a integração entre os aspectos psíquicos e fisiológicos da existência humana, ou seja, resolve o clássico problema das relações entre a alma e o corpo. A vida psíquica confunde-se com o foco presente, e os processos fisiológicos anônimos remetem a uma multiplicidade de instantes passados sedimentados na história corporal. Dado que o foco presente não é um instante pontual, mas sim, tal qual Merleau-Ponty insiste, um campo que envolve aberturas ao passado e ao futuro, as estereotipias da vida fisiológica nunca são totalmente estranhas ao sujeito e se integram à vida psíquica como dimensões por meio das quais essa última se realiza. Por sua vez, visto que a consciência presente jamais apreende totalmente o passado e o futuro, a vida fisiológica associada a essas dimensões não se submete plenamente às intenções subjetivas e, por vezes (como no caso das doenças), fragmenta a unidade da consciência subjetiva presente ${ }^{17}$.

Como se vê, Merleau-Ponty espera que o apelo à temporalidade forneça o critério de inteligibilidade para seu projeto de apresentar a ambígua camada da experiência pré-objetiva como originária em relação ao ser objetivo.

\section{B) As críticas ao projeto filosófico de Merleau-Ponty}

\section{Um estudo psicológico}

Em 1946, Merleau-Ponty é convidado para expor suas idéias num encontro da Sociedade Francesa de Filosofia, o qual foi publicado com o título $O$ Primado da Percepção e suas Conseqüências Filosóficas. Nesse encontro, após retomar algumas das principais teses da Fenomenologia da Percepção (publicada no ano anterior), Merleau-Ponty recebe diferentes críticas. Uma delas, formulada de maneira diferente por Émile Bréhier e Jean Hyppolite, procura desconectar as descrições da atividade perceptiva e a conseqüência, pretendida por Merleau-Ponty, de que a percepção envolve um modo originário de apresentação do ser. Para Bréhier, a reflexão filosófica surge exatamente para escapar dos paradoxos alimentados pela percepção vulgar e não deve, sob o risco de cair em incoerência, tomar a descrição da atividade perceptiva como

\footnotetext{
16 "A coisa e o mundo existem apenas vividos por mim ou por sujeitos tais como eu, pois são o encadeamento de nossas perspectivas, mas elas transcendem todas as perspectivas porque esse encadeamento é temporal e inacabado" (PhP, 385).

17 "A fusão da alma e do corpo no ato, a sublimação da existência biológica em existência pessoal, do mundo natural em mundo cultural é tornada ao mesmo tempo possível e precária pela estrutura temporal da nossa existência" (PhP, 100).
} 
critério ontológico (Cf. PP, 73). Já Hyppolite não vê nenhuma conexão teórica entre as descrições da percepção e as consequiências ontológicas buscadas por Merleau-Ponty (Cf. PP, 97). Ambos os filósofos separam, assim, atividade perceptiva e caracterização do ser do mundo, de maneira a reduzir a análise da experiência pré-objetiva a um registro de processos psicológicos, e a Fenomenologia da Percepção (em que tal análise foi exercida), a uma compilação de impressões subjetivas.

Merleau-Ponty responde a esse tipo de crítica em diversos momentos da sua carreira. Em uma nota de fevereiro de 1959, publicada em O Visível e o Invisível, o filósofo afirma que a Fenomenologia da Percepção não é um livro de psicologia, pois nela já há ontologia (VI, 228). Essa nota condensa uma reflexão longamente maturada. Em um texto menos conhecido, o manuscrito da primeira aula do curso $O$ mundo sensível e o mundo da expressão, ministrado no Collège de France em 1953, MerleauPonty explicita o tema apresentado sucintamente pela nota de $O$ Visível e o Invisível. No texto de 1953, o filósofo reconhece que a tese do primado da percepção pode ser interpretada de maneira errônea como fruto de um mero exercício de "fenomenologia", entendida como uma "introdução que deixava intacta a questão do ser" ${ }^{\text {". Merleau- }}$ Ponty rejeita tal interpretação ao afirmar: "eu não faço diferença entre ontologia e fenomenologia; (...) em nossa maneira de perceber está implicado tudo o que nós somos" ${ }^{19}$. Esse texto confirma que a intenção de Merleau-Ponty ao descrever a percepção em seus primeiros livros não era coletar dados psicológicos, mas sim explicitar um modo originário de manifestação do ser (o ser percebido).

A descrição da atividade perceptiva, na Fenomenologia da Percepção, longe de expor o exercício de uma função psíquica, tenta explicitar como as propriedades e relações constitutivas das coisas e eventos mundanos se manifestam sensivelmente. Há, por conseguinte, apesar de Hyppolite não o notar, uma clara conexão teórica entre descrições fenomenológicas e teses ontológicas no projeto de Merleau-Ponty: o modo como as coisas aparecem sensivelmente qualifica o modo como elas são. Além disso, se os resultados de tais teses parecem, à primeira vista, incoerentes (tal qual a caracterização do mundo como em-si-para-nós), não se trata de abandonar o domínio da sensibilidade em prol de uma suposta clareza racional, tal como Bréhier parece sugerir. Esse abandono significaria ignorar o problema da manifestação originária do ser para a subjetividade e, por conseguinte, mutilar injustificadamente a reflexão ontológica. Em

\footnotetext{
${ }^{18}$ Merleau-Ponty, M. Le monde sensible et le monde de l'expression, apud Saint Aubert, E. Op. cit., p.24.

${ }^{19}$ Id., ibid.
} 
vez disso, tal como sugere Merleau-Ponty ao estudar a temporalidade, basta encontrar um padrão de inteligibilidade pelo qual os resultados das descrições perceptivas possam ser logicamente assimilados.

Como se vê, o quadro teórico da própria Fenomenologia da Percepção contém argumentos que rejeitam as críticas de psicologismo endereçadas a tal obra. MerleauPonty confirma essa rejeição em $O$ Visível e o Invisível, texto em que, como vimos, reconhece explicitamente a intenção ontológica da Fenomenologia da Percepção. Apesar de tal reconhecimento, em $O$ Visível e o Invisível Merleau-Ponty também admite a necessidade de oferecer uma explicitação ontológica para os resultados da Fenomenologia da Percepção (Cf. VI, 234, fev. 1959), de modo a afastar os equívocos de se considerar esse texto como uma investigação psicológica. Cabe perguntar por que o autor levanta suspeitas acerca da eficiência de a Fenomenologia da Percepção veicular explicitamente suas intenções ontológicas. Em outra nota de $O$ Visível e $o$ Invisível, Merleau-Ponty admite o caráter insolúvel de alguns problemas da Fenomenologia da Percepção porque eles são formulados com base na distinção entre consciência e objeto (Cf. VI, 250, julho 1959). Essa nota fornece uma pista importante para entender as inquietudes do filósofo em relação à Fenomenologia da Percepção, as quais de fato já se exprimem nas notas do curso A Passividade, de 1954-1955. Nesse texto, Merleau-Ponty expõe a raiz das dificuldades do entendimento do projeto filosófico da Fenomenologia da Percepção: esse livro teria sido mal compreendido porque "a análise do percebido começa na ontologia comum. Ela se ultrapassa do interior. Mas o leitor não se dá conta” (IP, 174). Além disso, afirma Merleau-Ponty referindo-se a si mesmo, "o próprio autor, preso na ontologia comum, descobre o percebido como resíduo, exceção, resistência a essa ontologia" (Ibid.), o que geraria uma descrição redutora do campo fenomenal.

A ontologia comum a que Merleau-Ponty se refere em A Passividade é justamente aquela que cinde sujeito ou consciência e objeto, tal como $O$ Visível e o Invisível havia atribuído à Fenomenologia da Percepção. De fato, no livro de 1945 Merleau-Ponty admite partir do pensamento objetivo (o qual defende a existência de um mundo formado por propriedades independentes das funções sensoriais/cognitivas humanas e não apreensíveis diretamente por elas) para explicitar, dadas as deficiências internas a tal pensamento, a experiência fenomenal que o fundaria ( $\mathrm{Cf} . \mathrm{PhP}, 13$, nota 1). Essa explicitação legitima o tom otimista de A Passividade, segundo o qual a ontologia comum foi ultrapassada pela reflexão fenomenológica. Tal tom não mais figura na nota 
de $O$ Visível $e$ o Invisível, que simplesmente aponta para a incapacidade de a Fenomenologia da Percepção resolver a cisão entre consciência e objeto. Dessa maneira, $O$ Visível e o Invisível sugere que o ultrapassamento da ontologia comum pela Fenomenologia da Percepção (tal como descrito por A Passividade) não basta para livrar a doutrina fenomenológica de sérias dificuldades. Nós expusemos na seção anterior as linhas gerais desse ultrapassamento (Merleau-Ponty propõe o retorno do mundo determinado estudado cientificamente para a experiência pré-objetiva, de modo a acentuar o caráter secundário da objetividade em relação à vivência do mundo percebido pelo corpo. Assim, os fenômenos percebidos não são considerados conteúdos psicológicos, mas um modo de manifestação do próprio ser do mundo). Resta saber por que tal estratégia, segundo o próprio filósofo, não é plenamente eficaz.

\section{Merleau-Ponty idealista}

Além das críticas recebidas no debate promovido pela Sociedade Francesa de Filosofia, Merleau-Ponty também foi alvo de textos filosóficos que tentaram revelar limitações intrínsecas a seu projeto filosófico. Dois artigos se destacam pela agudeza com que expõem um ponto similar, a saber, supostas consequiências idealistas da filosofia de Merleau-Ponty. Trata-se de um artigo de Ferdinand Alquié ${ }^{20}$, o qual discutiremos nesta sub-seção, e outro de Jean Desanti ${ }^{21}$, comentado na próxima. Servimo-nos desses textos somente como um recurso para tornar visível a ineficácia do projeto da Fenomenologia da Percepção, tal como nós a interpretamos. Quer dizer que não os analisaremos em detalhe, mas apenas extrairemos algumas formulações argumentativas úteis para nossa exposição geral.

Em seu texto, Alquié sugere que Merleau-Ponty teria confundido os fenômenos percebidos, os quais são cronologicamente primeiros na ordem do conhecimento humano, com as propriedades daquilo que existe, as quais seriam primeiras na ordem do ser do mundo ${ }^{22}$. Ao atribuir alcance ontológico às descrições da atividade perceptiva, Merleau-Ponty teria submetido ilegitimamente o ser do mundo e do universo em geral às capacidades humanas de apreensão perceptiva, e só reconheceria como existente

\footnotetext{
${ }^{20}$ Alquié, F. "Une philosophie de l'ambiguïté. L'existentialisme de Merleau-Ponty". Fontaine Vol. IX, n.59, 1947, p.47-70.

${ }^{21}$ Desanti, J. T. "Merleau-Ponty et la décomposition de l'idealisme". La Nouvelle Critique, n.37, 1951, p.63-82.

${ }^{22}$ Alquié questiona: "Merleau-Ponty não confunde análise psicológica e análise metafísica, investigação do que é cronologicamente e psicologicamente primeiro e investigação do que é logicamente e metafisicamente primeiro?" (Alquié, art. cit., p.52-3).
} 
aquilo que pode se manifestar ao sujeito. Por conseguinte, Merleau-Ponty teria assumido um tipo de idealismo subjetivista ${ }^{23}$, uma postura filosófica incapaz de admitir a hipótese de que possa existir algo que exceda o campo de fenômenos apreensíveis perceptivelmente, hipótese essa que parece confirmada pelas teorias científicas acerca de radiações, raios ultravioletas, vírus e muitos outros eventos inobserváveis diretamente.

Antes de expor a resposta de Merleau-Ponty à hipótese dos entes inobserváveis, avaliemos a correção da crítica de Alquié. Para tanto, explicitaremos com mais detalhe o projeto filosófico da Fenomenologia da Percepção. Nesse livro, Merleau-Ponty defende o caráter originário da experiência pré-objetiva em relação à idéia de mundo objetivo como um conjunto de eventos independentes da subjetividade e que determinariam causalmente o conteúdo da percepção. A fim de legitimar tal tese, Merleau-Ponty tenta descrever aquilo que a experiência perceptiva efetivamente nos apresenta, ou seja, o mundo percebido (sobre o qual, posteriormente, o mundo objetivo é construído por meio de teorias e técnicas científicas). Os fenômenos pelos quais o mundo percebido se manifesta não são tomados por Merleau-Ponty como meros conteúdos psicológicos (como interpretações de um mundo formado por propriedades que, em si mesmas, não se doam sensivelmente), mas sim como a apresentação desse próprio mundo percebido. Quer dizer que a descrição fenomenológica da experiência não se limita a registrar uma representação psicológica, mas pretende desvelar as próprias coisas como são, o ser do mundo percebido. Por conseguinte, ao recusar a prioridade do mundo objetivo em prol do mundo percebido, Merleau-Ponty pretende oferecer uma caracterização do ser que está na origem da percepção.

Notemos que, para Merleau-Ponty, rejeitar o ser objetivo não significa rejeitar que a percepção seja resposta à solicitação de um mundo do qual o próprio sujeito surge e no qual permanece sempre engajado (Cf. PhP, 253). Na verdade, segundo o filósofo, a atividade perceptiva ocorre como uma sincronização de atitudes perceptivo-motoras com estímulos que solicitam a atenção corporal (Cf. PhP, 248). Dessa maneira, o funcionamento da percepção supõe um ser exterior com o qual o sujeito se comunica (Cf. PhP, 247). Merleau-Ponty chega mesmo a reconhecer, no início do capítulo "O sentir", que esse ser fundante da experiência não se limita ao ser sensível, mas envolve "uma profundidade do objeto que nenhuma antecipação sensorial esgotará" (PhP, 250),

\footnotetext{
${ }^{23}$ Cf. Ibid., p.64.
} 
um "horizonte de coisas vistas ou mesmo não visíveis" (PhP, 251). Aqui Merleau-Ponty considera rapidamente a idéia de um excesso do ser em relação ao aparato perceptivo humano, ou seja, admite que aquilo que existe ultrapassa o que pode ser sensivelmente discriminado pelos sujeitos humanos. No entanto, essa breve menção a tal idéia será mesmo recusada no decorrer da Fenomenologia da Percepção, conforme veremos.

A assunção de que há um ser exterior que motiva a percepção não justifica, segundo Merleau-Ponty, a teoria de que os episódios perceptivos são efeitos passivos de um mundo objetivo alheio às estruturas subjetivas. Conforme afirmamos acima, o filósofo descreve a experiência perceptiva como fruto de uma sincronização dos poderes perceptivo-motores do corpo com as situações factuais, que solicitam a atenção subjetiva. O sujeito não é invadido por um ser completamente estranho, mas assume uma postura perceptiva por meio da qual os dados percebidos se determinam e manifestam algo significativo. Dessa maneira, mais do que efeito do ser exterior, a percepção é, para Merleau-Ponty, reapresentação do mundo, quer dizer, exibição de fenômenos que expõem diretamente os eventos pelos quais o mundo existe ${ }^{24}$.

Tal descrição da atividade perceptiva implica que o mundo não é algo alheio à subjetividade e sim um campo de eventos cujos padrões de organização são esposados harmonicamente pelos poderes do corpo. Tal harmonia é fundada, segundo a Fenomenologia da Percepção, em um pacto ou contrato estabelecido naturalmente entre corpo e mundo (Cf. PhP, 251, 293, 359), de modo que a percepção sempre apreende significativamente os eventos mundanos com que se depara. Toda configuração particular de dados sensíveis exige e recebe uma sincronização corporal correspondente pela qual se apresenta como um fenômeno significativo, quer dizer, como reconstituição de um evento mundano. Esse resultado ocorre porque o corpo próprio, sistema de funções pré-pessoais, porta um projeto geral do mundo, um repertório perceptivo-motor capaz de sincronizar-se com toda situação factual possível $^{25}$. Vale notar que Merleau-Ponty não oferece nenhuma justificativa para a tese desse pacto natural entre corpo e mundo, o qual é apresentado como um fato último não remissível a nenhuma condição explicativa. Como veremos em nosso sexto capítulo, o

\footnotetext{
${ }^{24}$ A percepção "não se dá primeiramente como um evento no mundo ao qual se poderia aplicar, por exemplo, a categoria de causalidade, mas como uma re-criação ou uma re-constituição do mundo a cada momento" (PhP, 240).

25 "Há uma lógica do mundo que meu corpo inteiro esposa e pela qual coisas intersensoriais tornam-se possíveis para nós (...). Ter um corpo é possuir uma montagem universal, uma típica de todos os desenvolvimentos perceptivos e de todas as correspondências intersensoriais para além do segmento de mundo que nós percebemos efetivamente" (PhP, 377).
} 
filósofo busca uma resposta diferente ao problema da coordenação da atividade perceptiva com o ser do mundo em $O$ Visível e o Invisível, e, por meio da noção de reversibilidade, tenta elaborar uma justificativa de cunho ontológico para tal coordenação.

O reconhecimento de um pacto natural entre corpo e situações mundanas como fundamento da conformidade entre atividade percebida e ser do mundo não implica, segundo Merleau-Ponty, a redução desse ser a uma mera projeção subjetiva, a um correlato corporal. Desse modo, o filósofo rejeita a postura intelectualista segundo a qual haveria um poder geral subjetivo que portaria antecipadamente o sentido de toda experiência possível e atribuiria ativamente esse sentido aos fenômenos percebidos ${ }^{26}$. Conforme vimos na subseção anterior, Merleau-Ponty afirma que o sentido dos fenômenos percebidos aparece como uma propriedade intrínseca aos eventos mundanos e não como uma criação do sujeito. A percepção apenas exprimiria significações inerentes aos fenômenos, mas não as constituiria ativamente (Cf. PhP, 305). A idéia de pacto natural entre corpo e mundo somente afirma que o sujeito perceptivo porta a capacidade de reconhecer todas as configurações dos eventos mundanos. Mas o sentido dessas configurações não é criado pelo sujeito, pois faz parte dos próprios fenômenos mundanos: as coisas e o mundo se manifestam como portadoras de um sentido autônomo, como independentes da subjetividade (Cf. PhP, 372).

Poder-se-ia aqui objetar que o simples fato de que as coisas percebidas aparecem como existentes em si mesmas não basta como garantia de sua independência em relação à atividade perceptiva, já que esse aparecer é sustentado por tal atividade. Com efeito, Merleau-Ponty não se limita a reconhecer que as coisas surgem para a subjetividade como dela independentes, mas tenta esclarecer porque seu aparecer ocorre dessa maneira. Em nossa interpretação, o filósofo apresenta ao menos duas justificativas para o fato de que na própria experiência as coisas se manifestem como independentes do sujeito.

Antes de explorar essas justificativas, vale notar que Merleau-Ponty não apresenta como evidência para a irredutibilidade do ser do mundo a um correlato corporal a tese de que o ser motivador da percepção excede a manifestação sensível e contém camadas não diretamente acessíveis à subjetividade humana (tal como mencionado no início do capítulo "O sentir”). Na verdade, esse fato, reconhecido

\footnotetext{
${ }^{26}$ Essa postura intelectualista é explicitamente criticada no capítulo "O cogito", da Fenomenologia da Percepção.
} 
rapidamente naquele capítulo ao se investigar a gênese da percepção, perde qualquer relevância no interior da Fenomenologia da Percepção. Merleau-Ponty explica esse desprezo pelo excesso de ser em relação ao que é perceptível, anos mais tarde, no curso A Passividade. Ali, o filósofo esclarece que seu projeto na Fenomenologia da Percepção era "tomar como ser não o 'em-si', mas o que se manifesta"27. Lembremos que na Fenomenologia da Percepção, Merleau-Ponty defende que a percepção realmente apresenta o ser das coisas e não uma camada de qualidades secundárias projetadas sobre um mundo em si mesmo diferente daquilo que aparece sensivelmente. Admitir um excesso do ser em relação ao que aparece significaria, no quadro teórico desse livro, admitir que a realidade das coisas seria um em-si distinto de seu manifestarse, ou seja, um conjunto de propriedades objetivas que as capacidades perceptivas não conseguem captar. Quer dizer que na Fenomenologia da Percepção, a única alternativa à manifestação do mundo tal e qual pela atividade perceptiva é a idéia de um em-si completamente alheio às capacidades subjetivas. Daí que Merleau-Ponty se esforce, nesse livro, para esclarecer a existência autônoma do mundo sem apelar para um possível excesso do ser em relação ao seu aparecer. Veremos na conclusão desta tese, que em sua ontologia final, Merleau-Ponty rejeita o dilema entre conceber o ser como percebido (plenamente acessível pelo sujeito) ou como ser em-si (ser objetivo, inacessível para a sensibilidade). O filósofo francês desenvolverá a idéia de um ser que excede o aparecer fenomênico sem com isso retomar a idéia de um em-si formado por qualidades absolutamente alheias à subjetividade humana. Por ora, vejamos como ele defende a tese da existência autônoma do mundo sem apelo a um excesso do ser em relação ao aparecer.

Retornemos às duas justificativas pelas quais Merleau-Ponty tenta provar que o ser do mundo não se reduz a um correlato da experiência perceptiva. Como primeira delas, o filósofo assevera que o espetáculo percebido contém uma infinidade de relações constitutivas, que em muito ultrapassam aquelas apreendidas atualmente pelo corpo e que exigiriam um tempo interminável para serem devidamente exploradas (Cf. $\mathrm{PhP}, 373-4)$. Podemos, por exemplo, observar os contornos irregulares e o brilho fosco de uma pedra sem nos dar conta dos laivos delicados no seu interior. Se quebrarmos a pedra, perceberemos então os desenhos que escapavam à nossa primeira visada sobre

\footnotetext{
${ }^{27}$ Merleau-Ponty, M. La Passivité apud Saint Aubert, E. Op. cit., p.7.
} 
ela e que, ainda assim, dela faziam parte. Dessa maneira, as coisas e o mundo envolvem uma riqueza de detalhe e articulação que supera a experiência atual do corpo.

Merleau-Ponty reconhece que essa definição da coisa como infinidade de características é problemática, pois inesgotáveis aspectos constituintes das coisas jamais podem ser apreendidos por um sujeito finito, quer dizer, por um sujeito que conta com um tempo limitado e que só lida com perspectivas parciais dos fatos mundanos. Assim, se a confirmação da realidade de uma coisa depende da constatação de seus incontáveis atributos, então parece que tal confirmação nunca poderia ser feita ${ }^{28}$. A fim de superar esse problema, Merleau-Ponty expõe a segunda justificativa para a tese da existência autônoma das coisas para além da sua correlação com o corpo. Trata-se do caráter temporal da existência dos entes e do mundo em geral. Embora as coisas envolvam infinitos atributos, não é preciso considerar todos eles de uma só vez para confirmar a sua existência autônoma. Na verdade, se a totalidade dos atributos constituintes das coisas percebidas pudesse ser apreendida por um só ato subjetivo, então tais coisas seriam possuídas por inteiro pelo sujeito. Nesse sentido, as coisas seriam de fato reduzidas a um correlato de tal ato cognitivo (Cf. $\mathrm{PhP}, 269-70$ ). O apelo à temporalidade pretende esclarecer que não é a totalidade dos atributos constituintes das coisas a marca da sua realidade, mas sim a parcialidade pela qual eles se manifestam. Segundo Merleau-Ponty, as coisas se manifestam como uma série aberta, instaladas em um passado que o sujeito recolhe apenas parcialmente e suscetíveis a apreensões perceptivas futuras. Dessa maneira, a manifestação fenomênica das coisas será sempre inacabada, pois o sujeito apreende somente uma fase de uma história que ultrapassa aquilo que atualmente se doa. Justamente é esse inacabamento das coisas tal como manifestadas o que lhes garante sua realidade: as coisas percebidas dispõem de uma espessura passada e de uma abertura ao futuro que não são plenamente assimiláveis pela consciência presente. É verdade que essa consciência, tal como a concebe MerleauPonty, envolve uma abertura intencional ao futuro e ao passado; no entanto, o encadeamento dos instantes passados e futuros na experiência presente jamais implica a posse simultânea de todas as perspectivas e características que compõem a coisa. Os instantes passados e futuros são referidos à distância pela consciência presente, ou seja,

\footnotetext{
28 “Assim, parece que somos conduzidos a uma contradição: a crença na coisa e no mundo - só pode significar a presunção de uma síntese acabada, - e entretanto esse acabamento é tornado impossível pela própria natureza das perspectivas a religar, já que cada uma delas reenvia indefinidamente por seus horizontes a outras perspectivas" ( $\mathrm{PhP}, 381)$.
} 
são dimensões que lateralmente compõem a espessura da consciência atual, mas que não são direta e totalmente abarcadas pela vivência presente.

Cabe agora perguntar se as justificativas de Merleau-Ponty ao problema da independência do ser do mundo em relação aos sujeitos perceptivos são suficientes para afastar a acusação de idealismo subjetivista. Julgamos que não. O apelo para características e perspectivas temporais que escapam à sincronização presente do corpo significa somente que no plano da atualidade a estrita correlação entre os poderes do corpo e o ser do mundo não se concretiza. Porém, no nível da potencialidade, tal correlação é mantida. Afinal, Merleau-Ponty sustenta que o corpo porta a lógica do desenvolvimento de todo evento mundano ( $\mathrm{Cf}$. $\mathrm{PhP}, 377$ ), de modo que, embora as características e as perspectivas não percebidas atualmente excedam as posturas envolvidas na sincronização corporal presente, tais características consistem apenas em manifestações fenomênicas potencialmente apreensíveis pela percepção humana. De fato, o corpo não apreende todas as características e perspectivas das coisas simultaneamente, mas, em todo caso, não era por meio dessa totalidade inapreensível que Merleau-Ponty julgava estabelecer a independência do mundo ante a subjetividade, e sim por meio da parcialidade e inacabamento da manifestação mundana. No entanto, em nenhum momento o filósofo considera que as perspectivas parciais não sejam perfeitamente apreensíveis pelo corpo ${ }^{29}$. Cada uma delas permanece organizada segundo configurações materiais reconstituíveis pelo repertório perceptivo-motor corporal, o qual é caracterizado como "uma típica de todo ser possível, uma montagem universal em relação ao mundo" ( $\mathrm{PhP}, 490)$. O simples fato de que a organização dos eventos do mundo ocorra segundo um desenvolvimento temporal parece, assim, não bastar como prova da irredutibilidade do ser do mundo a um correlato corporal. Essa insuficiência se torna ainda mais clara se se retoma a teoria do tempo defendida pelo filósofo.

Segundo a Fenomenologia da Percepção, não há temporalidade (ou seja, eventos ordenados como presentes, passados ou futuros) no mundo considerado em si mesmo. A sucessão entre as dimensões do tempo (por exemplo, o tornar-se passado de um evento outrora futuro) surge pela relação entre sujeito e mundo. Os eventos mundanos recebem um sentido temporal porque são antevistos como protensões, são

\footnotetext{
29 "Não é necessário (...) perguntar se percebemos verdadeiramente um mundo, deve-se dizer, ao contrário: o mundo é aquilo que nós percebemos" (PhP, XI).
} 
apreendidos pela consciência presente e então retidos como instantes passados ${ }^{30}$. O caráter temporal das coisas (o fato de que elas fazem parte de uma história e são assim apreendidas de maneira inacabada) decorre da estrutura temporal da subjetividade e não pode, portanto, servir para provar a independência do mundo e das coisas ante tal subjetividade.

Os dois parágrafos anteriores pretendem mostrar que as razões apresentadas por Merleau-Ponty para justificar a impressão de que as coisas se manifestam como repousando em si mesmas não rompem com a limitação do ser do mundo àquilo que as capacidades perceptivas podem apreender. É verdade que o filósofo defende que as coisas contêm relações e perspectivas temporais que excedem a tomada de posição atual do corpo sobre o ambiente. No entanto, tais relações são apenas casos da lógica sensível dos eventos mundanos, a qual é partilhada totalmente pelo corpo, já que esse não só pode assumir as atitudes perceptivo-motoras necessárias para apreender qualquer manifestação fenomenal possível como também é responsável pela atribuição de um caráter temporal aos fatos do mundo. Parece, assim, que Alquié tinha razão em explicitar a posição de Merleau-Ponty como idealismo subjetivista.

É importante esclarecer o alcance da crítica de Alquié. Seria descabido acusar Merleau-Ponty de imaterialismo, pois claramente ele admite que a percepção responde a um ser exterior, que a solicita e que não é mera projeção humana. Também não seria correto atribuir a Merleau-Ponty a doutrina solipsista, como se o ser fosse aquilo que se manifestasse apenas para o narrador da Fenomenologia da Percepção. Nesse livro, a percepção é tratada como uma habilidade natural cujos padrões de funcionamento em princípio valeriam para todos os sujeitos humanos de igual constituição corporal, independentemente da diversidade cultural $^{31}$, uma habilidade que ligaria todos esses sujeitos a um mundo único e partilhável ${ }^{32}$. Os fenômenos percebidos não são, desse ponto de vista, eventos privados, mas acessíveis por qualquer consciência perceptiva humana. É claro que, ante uma mesma paisagem, dois sujeitos, localizados em posições

\footnotetext{
30 “O tempo não é um processo real, uma sucessão efetiva que eu me limitaria a registrar. Ele nasce de minha relação com as coisas" ( $\mathrm{PhP}, 471)$.

${ }^{31}$ Merleau-Ponty dá o exemplo da noção de permanência dos objetos apesar das oscilações do campo visual (quando da mudança do olhar) como uma habilidade que "não é aprendida, ela faz parte das montagens naturais do sujeito psicofísico" ( $\mathrm{PhP}, 59)$. No geral, as capacidades perceptivas descritas por Merleau-Ponty na Fenomenologia da Percepção são desse tipo, ou seja, são capacidades de um nível “que não é somente aquele de minha vida individual, mas aquele de 'todo homem"” (PhP, 505).

32 "Meu corpo, que assegura por meus hábitos minha inserção no mundo humano, só o faz justamente me projetando primeiramente em um mundo natural que sempre transparece sobre o outro" (PhP, 339). "As funções sensoriais e perceptivas depositam diante delas um mundo natural" (PhP, 400).
} 
diferentes, experimentam perspectivas diferentes. Mas tais diferenças estão previamente subsumidas ao horizonte perceptivo de cada um deles como possibilidades de eventos futuros. Cada perspectiva perceptiva, acredita Merleau-Ponty, deve ser concebida como partilhável por todos os sujeitos, de modo que nenhuma manifestação fenomênica se reduz a um espetáculo exclusivo de uma só subjetividade ${ }^{33}$.

Embora Merleau-Ponty admita um ser exterior que motiva a percepção e o caráter público dos fenômenos percebidos, julgamos que sua concepção ontológica geral limita tal ser a propriedades sensíveis que o corpo humano é capaz de reconhecer. Com efeito, há uma passagem em que Merleau-Ponty admite explicitamente a delimitação do ser àquilo que se manifesta à subjetividade:

as leis do nosso pensamento e nossas evidências são bem fatos, mas inseparáveis de nós, implicados em toda concepção que nós possamos formar do ser e do possível. Não se trata de nos limitar aos fenômenos, de fechar a consciência em seus próprios estados reservando a possibilidade de um outro ser além do ser aparente, nem de tratar nosso pensamento como um fato entre os fatos, mas de definir o ser como aquilo que nos aparece e a consciência como fato universal (PhP, 455, grifo nosso)

Aqui, Merleau-Ponty define o ser do mundo (ser exterior, que motiva a percepção) como ser sensível, ou seja, como um conjunto de atributos apreensíveis pelas capacidades perceptivas do corpo humano. O filósofo assume, como vimos, que tais atributos não são constituídos por atos subjetivos, e, por conseguinte, aparecem como repousando em si. Esses atos apenas reconstituiriam estruturas de organização próprias ao ser mundano. Porém, na doutrina da Fenomenologia da Percepção, tais estruturas são aquelas passíveis de reconhecimento subjetivo, de modo que em decorrência de um pacto originário o mundo é exatamente aquilo que se manifesta para o repertório perceptivo-motor do corpo ${ }^{34}$.

\footnotetext{
33 “As experiências dos outros ou aquelas que eu obteria me deslocando apenas desenvolvem o que está indicado pelos horizontes de minha experiência atual e a ela não acrescentam nada" (PhP, 390). Para Bimbenet, conforme vimos na introdução desta tese, essa certeza de que há uma concordância intersubjetiva no nível perceptivo explicitaria tendências intelectualistas na Fenomenologia da Percepção.

${ }^{34}$ Não é verdade, assim, tal como julga Madison, que "a análise de Merleau-Ponty acerca da coisa e do mundo natural levanta e deixa em suspenso a questão que é de fato a "besta negra" [bête noire] da fenomenologia. É a questão do estatuto ontológico do mundo, do ser do mundo" (Madison, G. B. Op. cit., p.32). Para Madison, Merleau-Ponty "não tem sucesso em elucidar (...) a velha questão da relação entre ser e aparecer, ser e fenômeno" (Ibid., p.36). Porém, Merleau-Ponty oferece claramente em seu livro de 1945 uma posição quanto às relações entre ser e aparecer: o fenomenólogo toma o que se fenomenaliza como ser, e, desse modo, identifica o ser do mundo ao seu aparecer. Pode-se questionar se essa resposta é
} 


\section{O problema do passado do mundo}

A circunscrição do ser do mundo àquilo que se manifesta para o repertório perceptivo-motor humano exclui a hipótese de que possa existir algo que exceda o campo de fenômenos apreensíveis subjetivamente. No entanto, muitos eventos que claramente extrapolam as capacidades perceptivas humanas foram reconhecidos por diversas teorias científicas. Pensemos, por exemplo, nas radiações, na fissão de partículas, nos genes, nos processos que geraram o universo e em tantos outros entes ou eventos inobserváveis diretamente, mas que podem ser apreendidos por meio de seus efeitos, esses sim compatíveis com as estruturas perceptíveis humanas. Qual estatuto ontológico é atribuído por Merleau-Ponty à categoria de entes ou eventos inobserváveis? O filósofo não aborda diretamente esse problema em seu caráter geral, mas discute um caso que esclarece sua postura filosófica ante tal gênero de dificuldade. Trata-se do tema da anterioridade de nosso planeta em relação à vida humana. A seguir, vamos enfatizar consideravelmente esse caso, pois vemos nele uma consequiência extraída por Merleau-Ponty de sua concepção ontológica geral, conseqüência por meio da qual será possível explicitar as limitações dessa concepção.

A concepção científica comumente aceita assevera que a Terra é um corpo celeste que em muito precedeu os seres humanos e, por conseguinte, as capacidades perceptivas segundo as quais os fenômenos mundanos são subjetivamente apreendidos. Merleau-Ponty avalia tal concepção ao analisar a hipótese do matemático e astrônomo Laplace (1749-1827), segundo a qual a Terra surgiu de uma nebulosa extremamente condensada e quente. O fenomenólogo interpreta essa hipótese da seguinte maneira: “cada uma dessas palavras como cada uma das equações da física pressupõe nossa experiência pré-científica do mundo e essa referência ao mundo vivido contribui para constituir sua significação válida" (PhP, 494). Quer dizer que a compreensão dos termos em que a hipótese de Laplace é formulada exige o apelo à experiência perceptiva ${ }^{35}$. Por exemplo, Merleau-Ponty defende que "nada me faria alguma vez compreender o que poderia ser uma nebulosa que não seria vista por ninguém" ( $\mathrm{PhP}, 494)$. O entendimento

adequada ou suficiente, tal como Alquié faz, mas não ignorar que ao menos há uma resposta ao problema em questão.

${ }^{35}$ Daí que para Merleau-Ponty "não há mundo sem uma Existência que lhe traga a estrutura” (PhP, 494). 
daquilo a que o termo "nebulosa" se refere supõe um testemunho perceptivo, ou seja, supõe imaginar o ente referido de um certo ponto de vista, manifestando-se de uma certa maneira para um suposto observador. Por conseguinte, para se referir ao passado do mundo ou mesmo para crer que tal passado existiu é necessário um campo perceptivo presente (Cf. PhP, 240). Nesse sentido, para Merleau-Ponty, esse passado não é algo que excede as estruturas perceptivas do corpo. Na verdade, o conjunto de fatos de que o passado do mundo se compõe só pode ser revelado, segundo essa perspectiva, por meio de constructos teóricos erigidos segundo as delimitações conceituais fornecidas pela percepção. Qual estatuto teórico conceder então aos eventos que compuseram esse passado? Eis a resposta de Merleau-Ponty: "a nebulosa de Laplace não está atrás de nós, em nossa origem, ela está diante de nós, no mundo cultural" (PhP, 494). Dado que para o filósofo todo ser concebível deve se moldar segundo os parâmetros do ser percebido, segue-se que os entes que pretensamente excedem essa estrita correlação são na verdade meras criações culturais que, embora tentem descrever eventos independentes e anteriores ao ser humano, decorrem das potencialidades cognitivas humanas.

Em um virulento artigo, Jean Desanti critica essa resposta ao problema dos entes e situações inobserváveis. Desanti interpreta a posição do fenomenólogo da seguinte maneira: “a terra, a natureza passam para o 'mundo cultural': elas não são mais 'seres', mas significações adquiridas sobre o fundo inalienável de uma experiência original e estritamente minha"36. Merleau-Ponty teria limitado aquilo que existe àquilo que se manifesta para o sujeito. Por conseguinte, os eventos que excedem tais capacidades seriam então concebidos como meras construções culturais. Assim, por exemplo, o passado do mundo não consistiria em um conjunto de fatos ocorridos de maneira autônoma, conforme advoga a visão científica, mas se reduziria a uma significação tardiamente construída com base nos fenômenos percebidos. Para Desanti, trata-se de uma tese inaceitável, já que os eventos astronômicos que deram origem à Terra ocorreram de maneira independente da experiência humana (a qual nem mesmo existia quando da sua realização) e não podem, portanto, ser reduzidos a construções da cultura humana.

Nas notas do curso A Passividade, Merleau-Ponty tenta responder às críticas recebidas de Desanti. Nesse texto, o filósofo esclarece que ao localizar a nebulosa da

\footnotetext{
${ }^{36}$ Desanti, J. T. Op. cit., p.71.
} 
hipótese de Laplace no mundo cultural, apenas rejeitava que tal ente fizesse parte de um em-si completamente independente da subjetividade humana. Para Merleau-Ponty, essa concepção de em-si não pode nem mesmo ser pensada (já que todo ser concebível supõe um testemunho perceptivo), de maneira que é impossível atribuí-la à nebulosa (Cf. IP, 172). Além disso, vale notar que Merleau-Ponty não defende que o ser do mundo é contemporâneo à percepção humana. Na Fenomenologia da Percepção, o filósofo esboça uma noção de passado do ser sem se comprometer com a idéia de um em-si independente da subjetividade. Segundo esse livro, o mundo se manifesta como já aí porque a própria percepção é um processo temporal que não só se abre para possibilidades futuras mas também reúne em sua visada atual as perspectivas passadas. Esse encadeamento de perspectivas passadas remeteria ao ser exterior na origem do processo perceptivo ${ }^{37}$. Dessa maneira, a percepção atestaria um ser sensível anterior a ela e que a alimentaria.

Serão essas respostas suficientes para sustentar as teses acerca do passado do mundo e, no geral, acerca dos entes inobserváveis? Primeiramente, avaliemos a tentativa de caracterizar o passado do mundo por meio da remissão da percepção ao ser exterior que a motivaria. Tal esforço nos parece insuficiente, pois apenas atesta que o ser que atualmente motiva a percepção não é constituído por ela, mas nada esclarece acerca da história desse ser antes de se apresentar como percebido, justamente o que está em questão com a hipótese da nebulosa. Em segundo lugar, quanto à réplica contida em A Passividade, ela somente repete a estratégia básica da Fenomenologia da Percepção (rejeitar a noção de ser em-si e conceber o ser do mundo com base na aparição fenomênica), mas não acrescenta nenhuma nova evidência contra as objeções de Desanti.

Vamos desenvolver por nossa conta a crítica de Desanti, a fim de tornar clara a insuficiência da posição de Merleau-Ponty acerca do problema dos entes ou eventos inobserváveis. Tal insuficiência decorre da confusão entre a concepção do ser como X e a existência do ser concebido como X. Merleau-Ponty defende que qualquer concepção possível do ser pressupõe um testemunho perceptivo e que, nesse sentido, qualquer concepção ontológica é relativa à nossa experiência pré-objetiva, a qual fornece os

\footnotetext{
37 "O ato de olhar é indivisivelmente prospectivo, pois o objeto está no termo de meu movimento de fixação, e retrospectivo, pois vai se dar como anterior à sua aparição, como o 'estímulo', o motivo ou o primeiro motor de todo o processo desde o seu início" ( $\mathrm{PhP}, 276-7)$.
} 
padrões últimos de compreensão dos eventos e coisas componentes do mundo ${ }^{38}$. Daí Merleau-Ponty afirmar que o passado do mundo não pode ser pensado como algo independente das estruturas perceptivas atuais humanas (Cf. PhP, 240). No entanto, julgamos que não se segue do fato de as concepções ontológicas serem relativas às estruturas perceptivas humanas que a existência do ser assim concebida ocorra em virtude dessas estruturas perceptivas ${ }^{39}$. Assim, embora Merleau-Ponty insista em que o passado do mundo só é concebível relativamente às estruturas perceptivas atuais, não se segue daí que a existência desse passado decorra dessas estruturas ou que seja delas dependente, tal como o filósofo parece inferir. Com efeito, Merleau-Ponty não admite explicitamente que não é em virtude das estruturas perceptivas que o ser do mundo se organiza, se sustenta e se modifica. Pelo contrário, o fato de que uma nebulosa deva ser concebida segundo parâmetros perceptivos basta para ela ser localizada no mundo cultural. O fenomenólogo não considera que tal nebulosa pudesse ser um ente que existiu no universo físico bem antes de qualquer mundo cultural ter sido criado. Em suma, ele não reconhece a existência autônoma e anterior do mundo para além da sua concepção segundo as estruturas da atividade perceptiva.

É importante observar que nenhum filósofo tem a obrigação de reconhecer tal autonomia e de, por conseguinte, desenvolver uma postura realista. No decorrer da história da filosofia, diversas posturas anti-realistas foram assumidas coerentemente. Aliás, notamos que Merleau-Ponty parece estar comprometido com uma delas, o idealismo subjetivista. No entanto, ele jamais admitiu tal postura. Assim, sua filiação ao idealismo não foi uma opção teórica, mas uma consequiência extraída por seus críticos ante algumas teses expostas na Fenomenologia da Percepção. Uma vez que MerleauPonty não distingue claramente entre a concepção do ser (dependente dos parâmetros perceptivos) e a existência do ser (independente de tais parâmetros), ele parece se comprometer, na Fenomenologia da Percepção, com a redução de tudo o que existe àquilo que se concebe segundo os parâmetros da percepção. Como acabamos de mencionar, Merleau-Ponty se nega a admitir tal conseqüência e tenta responder a seus críticos (Cf. IP, 172). Porém, conforme pretendemos mostrar a seguir, tal é o modo

\footnotetext{
${ }^{38} \mathrm{O}$ fenomenólogo concorda, nesse ponto específico, com a posição berkeleyana: “como dizia Berkeley, mesmo um deserto nunca visitado tem pelo menos um espectador, e este somos nós mesmos quando pensamos nele, quer dizer, quando fazemos a experiência mental de percebê-lo" (PhP, 370).

${ }^{39}$ Servimo-nos aqui da distinção entre ser relativo a um esquema conceitual e existir em virtude de um esquema conceitual, apresentada por Ernst Sosa em "Putnam's Pragmatic Realism". In: The Journal of Philosophy, Vol. 90, n.12, 1993.
} 
como o filósofo arma seu projeto na Fenomenologia da Percepção que é bastante plausível a interpretação dessa última como um projeto idealista.

\section{A correlação perceptiva}

Vimos que ao realizar o projeto de reconduzir o ser objetivo à sua gênese na experiência pré-objetiva, Merleau-Ponty define o ser do mundo como um conjunto de eventos e coisas cujas características constitutivas são exatamente aquelas apreendidas pela percepção. Dessa maneira, o filósofo exclui a possibilidade de que algo exceda a manifestação perceptiva. Aqueles eventos ou propriedades que aparentemente ultrapassam tal manifestação são considerados como constructos culturais tardios. Investigaremos, nesta subseção, as razões teóricas que comprometem Merleau-Ponty com tais teses.

O projeto filosófico da Fenomenologia da Percepção se enraíza em A Estrutura do Comportamento, mais especificamente na tentativa de transformar a correlação entre Gestalten (físicas, vitais ou psíquicas) e experiência perceptiva em um novo modelo para esclarecer as relações entre natureza e consciência. Essa tentativa implica uma interpretação transcendental dos resultados da Gestalttheorie, ou seja, implica abandonar a perspectiva materialista que, segundo Merleau-Ponty, caracteriza toda investigação psicológica (Cf. SC, 143), e trazer à luz o problema da constituição do mundo objetivo por meio da experiência das Gestalten. Dessa maneira, o filósofo se serve das pesquisas psicológicas para realizar uma redução fenomenológica moderada, que não culmina em um sujeito transcendental puro como condição da experiência e sim no corpo fenomenal entrelaçado em um campo de situações concretas. Tendo em vista esse campo concreto, Merleau-Ponty tenta descrever a constituição da objetividade.

Em que medida essa estratégia geral vincula o filósofo às conseqüências idealistas extraídas por seus críticos? Na apresentação de Merleau-Ponty à Sociedade Francesa de Filosofia em 1946, Jean Beaufret aponta um problema contrário àquele explicitado por Bréhier e Hyppolite. Vimos que esses autores não concordavam com a derivação de consequiências ontológicas das descrições da atividade perceptiva. Beaufret, por sua vez, não rejeita tal derivação, mas lamenta que ela não tenha sido bem realizada por Merleau-Ponty, que teria ficado preso ao vocabulário idealista de Husserl (Cf. PP, 103). Seria, assim, a filiação ao idealismo husserliano a razão das dificuldades de Merleau-Ponty. A pista oferecida por Beaufret nos parece profícua. Cabe agora 
examinar se realmente a apropriação da fenomenologia husserliana por Merleau-Ponty compromete-o com o idealismo.

Retomemos rapidamente alguns aspectos do projeto husserliano, a fim de avaliar como Merleau-Ponty se serve do instrumental desenvolvido pelo filósofo alemão. Ao menos a partir do texto A Idéia da Fenomenologia, composto por cinco palestras ministradas em 1907, Husserl desenvolve a fenomenologia transcendental, uma investigação filosófica que visa esclarecer de que maneira a possibilidade de conhecer eventos e objetos mundanos se funda nas estruturas da consciência. Nesse texto, a fim de delimitar tal vida subjetiva em seu caráter transcendental, Husserl primeiramente propõe a suspensão da crença na existência do mundo e do sujeito humano empírico (existência que compõe o que Husserl chama de transcendência). Em seguida, o filósofo se dedica a estudar o puro fluxo de vivências da consciência (denominado de imanência transcendental), ao qual não atribui nenhuma interpretação ontológica (por exemplo, se tal fluxo é efeito de processos fisiológicos, se é manifestação de um espírito, etc.). Uma vez executada tal redução fenomenológica, iniciam-se as investigações acerca da constituição da objetividade por meio das vivências fenomênicas. Cumpre notar que a análise dessas vivências, da imanência transcendental, não se limita aos conteúdos internos da consciência. O critério pelo qual Husserl delimita os temas a serem examinados é aquele da evidência, entendida como doação clara à apreensão subjetiva $^{40}$. Esse critério permite que os fenômenos mundanos sejam tematizados pela fenomenologia transcendental. Por exemplo, quando se observa um cubo, sempre duas ou três faces desse objeto se manifestam, e tais perspectivas são apreendidas com evidência. O cubo aparece para a consciência humana como uma manifestação fenomênica parcial, a qual não se confunde com a existência transcendente do cubo (definida como sólido de seis faces iguais), a qual não se doa de uma maneira fenomenologicamente evidente.

Embora os fenômenos apresentem os objetos mundanos, não se deve confundilos com tais objetos entendidos como entidades autônomas. Segundo Husserl, os fenômenos são os modos de apresentação de objetos, perspectivas parciais pelas quais coisas e eventos são apreendidos ${ }^{41}$. Tais modos de apresentação são subjetivos, no sentido em que eles sempre remetem ao ponto de vista do observador; mas eles não são

\footnotetext{
${ }^{40}$ Cf. Husserl, E. Die Idee der Phänomenologie - Fünf Vorlesungen. Hua. II, Haag: Martinus Nijhoff, 1950, p.17-18.

${ }^{41}$ Cf. Ibid., $\S 44-46$.
} 
internos à consciência, como, por exemplo, um ato de imaginação e seu conteúdo são. Na verdade, para Husserl, os modos de manifestação fenomênicos delimitam um campo neutro em relação à cisão entre interioridade mental e exterioridade mundana, delimitam um campo em que o mundo se manifesta de maneira subjetiva sem ser uma mera criação da consciência.

A primeira caracterização desse campo aberto após a redução fenomenológica é o seu estrito caráter correlacional em relação à atividade subjetiva. Segundo Husserl, todo fenômeno se relaciona a algum tipo de ato subjetivo pelo qual se manifesta e vice versa. Explicita-se aqui o a priori da correlação, a regra segundo a qual na investigação fenomenológica todo dado fenomenal deve ser remetido a um ato subjetivo e todo ato subjetivo deve ser estudado em seu caráter intencional, ou seja, enquanto se dirige para ou visa algo ${ }^{42}$. Essa regra direciona o desenrolar da investigação fenomenológica, a qual pretende mostrar como os fenômenos se manifestam por meio dos atos subjetivos e como, por meio do campo transcendental de fenômenos, a noção de objetividade é constituída.

Cumpre notar que a investigação husserliana não se dedica a estudar fenômenos particulares, mas sim a essência, ou seja, os aspectos invariantes que definem classes de fenômenos ${ }^{43}$. Assim, por exemplo, não interessa examinar as características de um cubo ou de uma casa percebida, mas sim a maneira pela qual fenômenos de objetos materiais, com formas reconhecíveis visual ou tactilmente e que duram no tempo (quer dizer, fenômenos com tais características eidéticas) se organizam em correlação com as capacidades perceptivas humanas. Além disso, Husserl não pretende teorizar acerca do ser dos objetos transcendentes, já que o domínio fenomenológico só abarca a manifestação de tais objetos, mas não a sua existência transcendente. Dessa maneira, Husserl mantém uma nítida distinção entre o objeto considerado como um ente existente por si próprio e o objeto como conjunto de modos de doação subjetivos (objeto intencional). Um exemplo de A Crise das Ciências Européias e a Fenomenologia Transcendental deixa clara a restrição da fenomenologia ao estudo da aparição do ser, sem se enveredar pela teorização acerca do próprio ser: "de uma árvore, pode-se enunciar que ela queima, mas uma árvore percebida 'enquanto tal' não pode queimar"44. Husserl exemplifica aqui a diferença entre fenômeno e objeto: o primeiro é um

\footnotetext{
${ }^{42}$ Ibid., p.73.

${ }^{43}$ Id., ibid.

${ }^{44}$ Husserl, E. Die Krisis der europäischen Wissenschaften und die transzendentale Phänomenologie. Hua. VI. Haag: Martinus Nijhoff, 1962, § 70, p.245.
} 
componente da correlação fenomenológica entre pólo subjetivo e objeto intencional e só se sustenta enquanto vigora tal correlação; já o segundo é um ente autônomo submetido a modificações físico-químicas. Atribuir tais modificações ao fenômeno seria confundir o domínio da atitude fenomenológica com o domínio dos entes naturais estudados pelas ciências empíricas.

É claro que Husserl não almeja duplicar o mundo, como se houvesse os objetos neles mesmos e, diferentes desses, os objetos intencionais ou fenomenais. Os fenômenos são justamente a manifestação do objeto transcendente. No entanto, Husserl parece considerar que nem todas as propriedades que se sabe pertencer aos objetos transcendentes podem ser verificadas por meio dos modos de doação fenomênico (conforme mencionamos quanto ao exemplo do cubo). Quer dizer que o objeto puro e simples pode envolver um complexo de propriedades não necessariamente apreensíveis fenomenalmente. Daí a necessidade de manter a diferença entre objeto puro e simples ou transcendente e manifestação fenomênica. É verdade que o objeto intencional não é um outro objeto, completamente diferente do objeto transcendente, e sim o modo como esse objeto se manifesta. Mas essa tese não implica que a totalidade das propriedades objetivas de direito se manifestará como fenômeno.

Voltemos agora ao projeto fenomenológico de Merleau-Ponty. Certamente esse filósofo herda e reconfigura vários temas da fenomenologia husserliana, estabelecendo com essa última uma relação complexa, cuja amplitude tentaremos delinear no quinto capítulo. Mas que dizer especificamente do a priori da correlação? Merleau-Ponty mantém tal princípio? Certamente não há, em seus textos, a assunção de regras universais a priori, que dirigem todas as descrições particulares. Trata-se, nesses textos, justamente de descrever diferentes casos concretos para explicitar as maneiras típicas pelas quais o corpo humano se insere no mundo percebido. No entanto, à medida que se expõem seus resultados, as descrições fornecidas por Merleau-Ponty instauram uma rígida correlação entre o mundo percebido e os poderes perceptivo-motores do corpo humano. Por um lado, o filósofo defende que "é essencial à minha visão se referir não somente a um pretenso visível, mas ainda a um ser atualmente visto" (PhP, 429). Dessa maneira, a análise dos episódios perceptivos sempre envolve a exposição de alguma situação mundana efetiva. Por outro lado, lembremos que as capacidades perceptivas humanas portam "o projeto de todo ser possível" (PhP, 411), de maneira que a investigação de qualquer evento do mundo remete a alguma capacidade perceptiva. Por conseguinte, ao menos no nível das funções perceptivas, Merleau-Ponty assume uma 
estrita correlação entre pólo subjetivo e mundano, de modo que, nessa esfera, vigora um princípio descritivo semelhante ao a priori da correlação husserliano, chamado por nós de correlação perceptiva.

Deve-se notar que a correlação perceptiva transforma significativamente a idéia de a priori da correlação, formulada por Husserl. A mútua relação acentuada por Merleau-Ponty não ocorre entre puras essências e puros atos subjetivos (tal como sugeria Husserl ao menos em A Idéia da Fenomenologia), mas entre fenômenos concretos e o corpo fenomenal. Esses fenômenos concretos não são, para o filósofo francês, representações de um ser que em si mesmo poderia divergir daquilo que aparece, mas sim, conforme sua teoria da atividade perceptiva, a reconstituição do modo pelo qual os eventos e entes materiais existem ${ }^{45}$. Vimos que para Merleau-Ponty o que se manifesta fenomenalmente é uma perfeita reconstituição do ser do mundo, reconstituição decorrente das sincronizações de atitudes perceptivo-motoras ante as solicitações sensíveis. Tal perfeição seria fundada em um pacto natural segundo o qual as propriedades pelas quais as coisas e eventos se organizam são exatamente aquelas apreendidas pela subjetividade. E uma vez que aquilo que se manifesta para a percepção é o próprio ser das coisas (ainda que numa progressão interminável), de direito a correlação perceptiva proposta por Merleau-Ponty apreende o mundo em sua total complexidade. Assim, a idéia de a priori da correlação (a qual Husserl formulara como critério de demarcação epistemológica do campo fenomenológico) passa a servir de princípio de delimitação ontológica, pelo qual se decide sobre aquilo que é: tudo o que pode existir deve ser apreensível pelas capacidades perceptivas.

Para Merleau-Ponty, o ser das coisas e do mundo é exatamente o que se manifesta fenomenalmente (Cf. $\mathrm{PhP}, 455)$. Ele não considera que possa haver propriedades que não sejam apreensíveis diretamente pela percepção. Dessa maneira, a diferença entre objeto puro e simples e fenômenos é dissolvida. O estudo desses últimos pretende esgotar as propriedades do primeiro. Essa postura é confirmada no texto "O metafísico no homem", de 1947. Ali, o filósofo assevera que há um "fato metafísico fundamental", ou seja, uma base sobre a qual toda sua teoria ontológica se erige. Esse fato fundamental se exprime na dupla afirmação: “eu estou certo de que há ser - sob a

\footnotetext{
45 Por exemplo, Merleau-Ponty afirma que "a perspectiva não me aparece como uma deformação subjetiva das coisas, mas ao contrário como uma das suas propriedades, talvez sua propriedade essencial" (SC, 201). Assim, o fato de que as coisas se manifestam parcialmente, segundo uma determinada perspectiva, deve ser considerado um fator componente do ser de tais coisas, então definidas como intrinsecamente parciais, inacabadas.
} 
condição de não buscar outro tipo de ser que o ser-para-mim" (SnS, 114). Dessa maneira, a investigação ontológica deve se limitar a estudar o ser passível de apreensão subjetiva. Dada essa tese, acreditamos que dificilmente Merleau-Ponty pode recusar a consequiência de ter se filiado a um certo tipo de idealismo, conforme Alquié já apontara.

Vimos que Jean Beaufret suspeitava que as dificuldades na doutrina da Fenomenologia da Percepção vinham de certos princípios da obra de Husserl. Porém, não é verdade que Merleau-Ponty simplesmente se filiou ao idealismo transcendental husserliano. O filósofo francês o modifica em uma doutrina própria, com a qual dificilmente Husserl concordaria. Husserl mantém uma distinção entre atitude transcendental e atitude natural, entre objeto intencional e objeto puro e simples. Já Merleau-Ponty parece unificar os domínios da atitude transcendental (referente à manifestação do ser) com aquele da atitude natural (referente à caracterização do ser). Dessa maneira, faltam instrumentos teóricos para reconhecer qualquer tipo de ser que exceda aquilo que é apreensível diretamente pelas capacidades perceptivas.

O fato de que Merleau-Ponty parece não dispor de meios teóricos, nos anos quarenta, para anular as conseqüências idealistas de seu projeto filosófico pode ter motivado a avaliação tardia de que certos problemas da Fenomenologia da Percepção eram insolúveis (Cf. VI, 250, julho 1959). Vimos que Merleau-Ponty admitira partir, nessa obra, da ontologia comum (que opõe sujeito e objeto) e buscar um meio ontológico neutro, anterior à tal cisão. Porém, como resultado, parece ter favorecido excessivamente as estruturas subjetivas, as capacidades perceptivas humanas. Assim, o meio ontológico a que o filósofo efetivamente chega se limita a uma expressão dos poderes da subjetividade encarnada. É verdade que Merleau-Ponty, nos anos quarenta, rejeitou a idéia de um ser objetivo completamente alheio às estruturas subjetivas mas não consegue conceber o mundo senão como subjetivo, quer dizer, como limitado às estruturas perceptivas humanas ${ }^{46}$. Daí a incapacidade de a Fenomenologia da Percepção superar a cisão entre sujeito e objeto: tal obra somente favorece um dos termos dessa cisão, mas, dessa forma, ainda se submete a ela. É essa incapacidade inerente ao projeto da Fenomenologia da Percepção que os textos seguintes de Merleau-Ponty tentarão corrigir, como veremos no decorrer desta tese.

\footnotetext{
46 “O sujeito é ser-no-mundo e o mundo permanece 'subjetivo' pois sua textura e articulações são desenhadas pelo movimento de articulação do sujeito" (PhP, 491-2).
} 


\section{C) $O$ desenvolvimento da ontologia de Merleau-Ponty}

Tentamos expor, na seção anterior, de que modo a investigação fenomenológica de Merleau-Ponty já envolve teses sobre o ser do mundo e mesmo do universo em geral. Essa exposição nos leva a rejeitar a interpretação de que a Fenomenologia da Percepção é apenas uma obra preliminar em relação ao desenvolvimento de uma ontologia por Merleau-Ponty ${ }^{47}$. Também acompanhamos que certas posições defendidas naquele livro implicam conseqüências idealistas, as quais o filósofo reluta em assumir. É importante notar, tal como comenta Emmanuel de Saint Aubert, que as críticas recebidas por Merleau-Ponty repercutiram nas reflexões posteriores do filósofo: ele não só retorna várias vezes ao conteúdo de tais críticas para tentar respondê-las mas também insiste na necessidade de esclarecer o alcance ontológico dos resultados da Fenomenologia da Percepção, de maneira a evitar interpretações como aquelas de Alquié e Desanti (Cf. VI, 228, 234, fev. 1959) ${ }^{48}$. Haverá, por conseguinte, um esforço da parte de Merleau-Ponty para elucidar e desenvolver suas teses ontológicas, o qual tentaremos acompanhar em detalhe ${ }^{49}$. Veremos que Merleau-Ponty formulará uma concepção não idealista do ser que motiva a percepção, sem, no entanto, definir tal ser como em-si objetivo.

A fim de facilitar metodologicamente a exposição desse resultado final da ontologia de Merleau-Ponty, identificamos três linhas de reflexão pelas quais ele se realiza $^{50}$. Na primeira delas, Merleau-Ponty retoma alguns temas esboçados na Fenomenologia da Percepção a fim de retificar algumas das teses ali expostas. Esse percurso se compõe principalmente dos cursos $A$ Instituição, $A$ Passividade e $A$ Natureza; nós o exploramos no terceiro capítulo. Na segunda linha, Merleau-Ponty aprimora a idéia de que a investigação ontológica deve ser indireta, princípio que já está em funcionamento em A Estrutura do Comportamento e Fenomenologia da Percepção. Os principais textos que servem a tal propósito são Notas de Cursos 1959-1961 e O

\footnotetext{
${ }^{47}$ Posição defendida por R. Barbaras em De l'être du phénomène. Sur l'ontologie de Merleau-Ponty. Ed. supra, p.12.

48 Após expor as críticas de Alquié a Merleau-Ponty, Saint Aubert comenta: “como se pode imaginar, esse retrato de idealista, mais ainda que os outros, acabou por desconcertar o interessado, que ruminará a crítica de Alquié até os últimos manuscritos envolvendo O Visível e o Invisível e Ser e Mundo" (Saint Aubert, E. Op. cit., p.29). Em seguida, para legitimar seu comentário, Saint Aubert transcreve diversos textos inéditos em que Merleau-Ponty analisa as críticas de Alquié.

${ }^{49}$ Rejeitamos, assim, a tese de M. C. Dillon, segundo a qual toda a ontologia ulterior Merleau-Ponty é apenas uma explicitação de teses já prefiguradas na Fenomenologia da Percepção. Cf. M. C. Dillon, Merleau-Ponty's Ontology. Evanston: Northwestern Univ. Press, 1997, p.155.

${ }^{50}$ Merleau-Ponty não distingue, tal como as exporemos, tais linhas. No entanto, tal distinção é bastante útil para reconhecer nos diversos textos e cursos do autor uma progressão rumo à sua ontologia final.
} 
Olho e o Espírito, os quais serão estudados no capítulo quarto. Na terceira linha, Merleau-Ponty elabora uma longa reflexão crítica, espalhada em diversos textos, acerca da fenomenologia, e tenta extrair dessa doutrina uma noção ampliada do ser, não mais limitada às capacidades subjetivas de discriminação de fenômenos. Essa reflexão será exposta em nosso quinto capítulo. Tentaremos, com tal divisão temática, levar em conta os principais momentos da elaboração da ontologia de Merleau-Ponty, que culmina com o texto inacabado $O$ Visível e o Invisível, o qual analisaremos no sexto capítulo desta tese.

Antes de expor os três caminhos pelos quais acreditamos que a ontologia de Merleau-Ponty se desenvolve, vamos nos dedicar a um outro tema, em nosso segundo capítulo, com repercussões claras sobre a reflexão ontológica. Trata-se da investigação da linguagem. No curso A Passividade, o filósofo admite que na Fenomenologia da Percepção havia acentuado demasiadamente a experiência sensível de coisas e deixado de lado os aspectos culturais imediatamente envolvidos na doação fenomênica (Cf. IP, 174). A Fenomenologia da Percepção concebe a atividade perceptiva como um contato com um fundo de natureza universalmente partilhado sob as diferentes culturas (Cf. PhP, 339-340). Mas, conforme Merleau-Ponty defende nos anos cinqüenta, essa concepção oculta o fato de que toda coisa natural se manifesta por meio de algum contexto cultural e de que, de certo modo, a percepção se desenvolve historicamente (Cf. IP, 178). Em um texto de 1951, intitulado "Titres et Travaux", o filósofo já admite o caráter artificial do âmbito da percepção sensível tal como descrita pelo Fenomenologia da Percepção ${ }^{51}$. Não haveria, segundo tal texto, um puro campo de fenômenos sensíveis a ser descrito, já que o sujeito da percepção só pode fixar os dados percebidos por meio dos recursos lingüísticos (Cf. PII, 23). Daí a preocupação de Merleau-Ponty em investigar o papel da linguagem na constituição do campo fenomenal e em tornar explícita, de um modo geral, a contribuição da cultura na inserção humana no mundo (Cf. IP, 175) ${ }^{52}$.

A investigação da cultura complexifica a reflexão ontológica de Merleau-Ponty. O filósofo reconhece uma crise nas inter-relações humanas e em suas expressões

\footnotetext{
51 "É por uma abstração metódica que fingimos, começando, nos encontrar no mundo mudo da percepção". (PII, 22).

52 A linguagem já é tema de um capítulo da Fenomenologia da Percepção, intitulado "O corpo como expressão e a fala". Mas ali se trata principalmente de apresentar a linguagem como uma intencionalidade do corpo e não como fator cultural constituinte do campo fenomênico. Em todo caso, o caráter corporal da fala, tese discutida naquele capítulo, ecoará nos demais textos de Merleau-Ponty sobre o tema, conforme veremos no próximo capítulo.
} 
artísticas, a qual abala as categorias filosóficas básicas (tais como sujeito, objeto, sentido - Cf. VI, 219, jan. 1959) e sugere uma renovação do discurso ontológico. A crise da cultura é, assim, uma oportunidade para forjar categorias que melhor exprimam o contato humano com o real. A meta de Merleau-Ponty é explicitar filosoficamente uma nova noção de ser que já se deixaria entrever em meio às convulsões da vida cultural contemporânea (Cf. NC, 37). Desse modo, como veremos no decorrer de nossos capítulos, a formulação de uma ontologia por Merleau-Ponty não é uma tarefa que se limita a sanar alguns problemas teóricos de seus primeiros textos, mas um empreendimento que visa renovar as bases dos sistemas simbólicos e das relações interpessoais da civilização contemporânea. 


\section{Capítulo II - Investigações sobre a linguagem}

\section{Sinopse}

Neste capítulo, contrastamos a relação entre atividade lingüística e perceptiva tal qual apresentada pela Fenomenologia da Percepção (baseada na tese do sentido gestual ou emotivo das palavras) com aquela desenvolvida após a apropriação da lingüística de Saussure. A postura final de Merleau-Ponty quanto a essa relação servirá de princípio metodológico pelo qual a sua ontologia será desenvolvida.

\section{A) Expressividade e consciência silenciosa}

\section{O papel da linguagem}

A partir dos anos cinqüenta, Merleau-Ponty almeja alargar suas pesquisas fenomenológicas de modo a incluir o campo do conhecimento e da cultura em geral entre os temas estudados (Cf. PII, 41). A Fenomenologia da Percepção, julga o filósofo em 1954, permanece excessivamente centrada na análise da apreensão sensível solitária de coisas ou situações e não atribui o devido peso às inter-relações culturais, as quais, como veremos, interferem na doação fenomênica (Cf. IP, 174). No livro de 1945, Merleau-Ponty simplesmente considera a atividade perceptiva como fundante de todos os demais atos subjetivos (Cf. PhP, V) e, na medida em que admite que tal atividade liga todos os sujeitos a um mundo natural aquém de toda particularidade antropológica (Cf. PhP, 381), também a considera fundante das relações intersubjetivas. Porém, nos anos cinqüenta, o filósofo admite que as capacidades perceptivas são ao menos parcialmente moldadas pelo contexto social e cultural em que se desenvolvem ${ }^{1}$. A percepção não ofereceria, dessa maneira, conteúdos pré-culturais disponíveis a quaisquer sujeitos; a atividade perceptiva seria parte de uma experiência global composta por diversos elementos civilizacionais (tais como hábitos, crenças, e conhecimentos técnicos).

Uma consequiência dessa nova delimitação da atividade perceptiva é a ausência de uma passagem direta entre a vivência sensível e as inter-relações sociais. $\mathrm{Na}$ Fenomenologia da Percepção, a atividade perceptiva é descrita não como um poder ligado à individualidade de cada corpo, mas como um conjunto de operações anônimas universalmente partilhadas por todos os humanos de mesma constituição

\footnotetext{
1 “A ‘coisa natural’ só aparece como tal a uma cultura. Há uma história da percepção” (IP, 178).
} 
psicofisiológica (Cf. PhP, 45-6, 59, 505). Além disso, os conteúdos percebidos, longe de serem concebidos como eventos privados, são apresentados como perspectivas do mundo acessíveis aos diferentes sujeitos perceptivos ${ }^{2}$. Tais conteúdos não são átomos singulares, sem comum medida com a experiência alheia, mas cristalizações de situações típicas pelas quais o mundo se apresenta a todos os sujeitos perceptivos, os quais, por conseguinte, não estão jamais isolados em vivências perceptivas absolutamente individuais ${ }^{3}$. Desse modo, segundo a Fenomenologia da Percepção, as experiências sensíveis não implicam privacidade e já são organizadas como um campo intersubjetivamente partilhável. Porém, se, tal como Merleau-Ponty admite nos anos cinqüenta, a percepção envolve parâmetros culturais e sociais em suas capacidades discriminativas, então ela deixa de valer como instância imediata de mútua compreensão silenciosa.

É verdade que Merleau-Ponty não descarta o caráter partilhável da vida sensível nos anos cinqüenta. Em A Prosa do Mundo (de 1951-1952), Merleau-Ponty defende que "há uma universalidade do sentir - e é sobre ela que repousa (...) a generalização do meu corpo, a percepção de outrem" (PM, 191). Assim, o sujeito, considerado como corpo que percebe, é um organismo anônimo que não exclui a perspectiva de outros sujeitos perceptivos. No entanto, tal como pretendemos mostrar, nessa época, o filósofo parece reconhecer que a universalidade do sentir não se impõe por si própria e não pode valer, isoladamente, como garantia de compreensão intersubjetiva. O estudo das relações intersubjetivas e culturais efetivas, tal como pretendido por Merleau-Ponty para alargar as análises da Fenomenologia da Percepção, exige a exploração detalhada de um outro tópico, a saber, o da linguagem. Como veremos, será apenas por meio da linguagem que a experiência sensível, marcada pelo contexto histórico-cultural, poderá realmente valer como universalidade sensível ${ }^{4}$.

Não pretendemos, neste capítulo, reproduzir toda a complexidade das análises elaboradas por Merleau-Ponty sobre a linguagem. Apenas tentaremos esboçar os traços

\footnotetext{
2 "As experiências de outrem ou aquelas que eu obteria me deslocando apenas desenvolvem o que está indicado pelos horizontes de minha experiência atual e a ela não acrescentam nada" (PhP, 390).

3 "Consideremos por exemplo o sentir. (...) Entre essa experiência do vermelho que eu tenho e aquela de que os outros me falam nenhuma confrontação direta será alguma vez possível. (...) Entretanto, a individualidade dessas experiências não é pura. (...) $\mathrm{O}$ vermelho concreto se destaca então sobre um fundo de generalidade e é por isso que, mesmo sem passar ao ponto de vista de outrem, eu me apreendo em minha percepção como um sujeito perceptivo e não como uma consciência sem igual" (PhP, 514-5).

${ }^{4}$ Em um texto de 1951, em que apresenta um projeto de ensino por ocasião de sua candidatura ao Collège de France, Merleau-Ponty afirma que "nos é necessário ver como nossa própria encarnação, pelo uso lingǘstico que fazemos do nosso corpo, é o que nos permite, de uma certa maneira de não permanecer confinados nos limites de nosso ponto de vista tal como ele é definido pelo corpo 'natural"' (PII, 24).
} 
gerais de duas concepções de linguagem presentes em sua obra, a primeira exposta na Fenomenologia da Percepção e a segunda elaborada no início dos anos cinqüenta. Nossa principal meta será esclarecer que ao desenvolver sua segunda concepção de linguagem (a qual implica uma autocrítica quanto a alguns aspectos da primeira), Merleau-Ponty formula as bases da estratégia metodológica pela qual se dedicará à sua ontologia madura.

\section{A expressividade da fala}

Antes de expor as teses maduras de Merleau-Ponty sobre a linguagem e suas relações com a percepção, vamos acompanhar suas reflexões iniciais sobre o tema, de modo a tornar explícitas, em seguida, as modificações propostas nos anos cinqüenta. No capítulo da Fenomenologia da Percepção intitulado "O corpo como expressão e a fala", Merleau-Ponty defende a tese de que o pensamento não preexiste à sua expressão lingüística. $\mathrm{O}$ argumento para tal é um modus tollens, irrecusável quanto à sua forma: se a fala pressupusesse um pensamento anterior, então sempre haveria clareza antecipada sobre aquilo que vai ser dito. Porém não há essa clareza. Logo, não há um pensamento prévio condicionando a fala. Para garantir a verdade da segunda premissa, MerleauPonty evoca uma situação bastante habitual para oradores e escritores: a tomada de consciência de certas idéias apenas quando da sua formulação explícita (Cf. PhP, 206). Essa situação revela que, longe de ser um veículo exterior de significações intelectuais prévias, a fala realiza o pensamento.

Pode-se apresentar como exceção à evidência fornecida por Merleau-Ponty as situações em que os sujeitos têm plena clareza da sua intenção intelectual bem antes de a formularem explicitamente (quando se quer saber as horas ou pedir alguma informação, por exemplo). De fato, o filósofo admite a existência desse tipo de situação lingüística, em que a fala somente repete um sentido já sedimentado, sem nenhuma intenção criativa. Trata-se, nesse caso, da fala secundária, a qual traduz um pensamento já delineado anteriormente (Cf. PhP, 446). É preciso distinguir desse uso reprodutivo da linguagem, uma fala originária, a qual, formula um sentido inédito. É no caso dessa fala originária que o sujeito não pensa previamente o sentido daquilo que diz, pois o seu pensamento será justamente produzido pelo ato de expressão. Não há, nesse caso, o apelo a idéias já estabelecidas (tais como "as horas" ou “o caminho", no caso de questões sobre horários e localizações), que são então meramente representadas por vocábulos, mas sim a aplicação de um poder de criar sentido por meio das próprias 
palavras. A fala se aproxima, assim, da intencionalidade gestual, a qual também dispensa uma representação intelectual prévia do fim a ser alcançado pelo corpo. Os gestos seguem uma inteligibilidade espontânea do corpo, que sabe se pôr em situação sem calcular intelectualmente os ângulos e distâncias envolvidos em seus movimentos. Para Merleau-Ponty, tanto a fala quanto os gestos são casos de um poder geral pelo qual o corpo utiliza suas capacidades para organizar um meio significativo (Cf. $\mathrm{PhP}, 221$ ).

Merleau-Ponty considera que a operação expressiva da fala difere em ao menos um ponto das demais intencionalidades corporais. Trata-se do fato de que a fala se sedimenta e institui um saber intersubjetivo. As significações criadas pela fala originária de um sujeito podem ser retomadas por outros e se tornarem um recurso expressivo disponível a vários falantes. $\mathrm{Na}$ verdade, crê Merleau-Ponty, todas as significações já cristalizadas e repetidas pela fala secundária foram em algum momento significações pronunciadas pela primeira vez e que fixaram um sentido inexistente outrora (Cf. $\mathrm{PhP}, 226)$. Desse ponto de vista, a fala originária alimenta a fala secundária. Porém, o filósofo nota que o contrário também ocorre: a fala originária supõe um sistema lingüístico devidamente estabelecido, composto por um vocabulário e uma sintaxe definida, o qual serve de base para que uma significação inédita seja criada. Há assim uma circularidade inerente ao processo da fala: cada ato veiculando um novo sentido se ergue de um sistema lingüístico previamente disponível, o qual, por sua vez, não é senão uma sedimentação de inúmeros atos que outrora criaram um sentido inédito (Cf. PhP, 229).

Merleau-Ponty expõe duas conseqüências da sedimentação da linguagem. A primeira delas é a idéia de que há um pensamento independente da expressão lingüística. Dado que a maior parte das falas cotidianas apenas reitera formas expressivas cujas significações já são mutuamente partilhadas e não exigem nenhum esforço compreensivo, parece então que a atividade lingüística decorre de um pensamento conceitual anterior às palavras. Cria-se assim a ilusão de que há uma vida conceitual da consciência independente das habilidades expressivas. Contudo, o pensamento, entendido como posse de idéias claras, é, segundo Merleau-Ponty, um resultado da fala originária e não sua condição (Cf. $\mathrm{PhP}, 446)$.

A segunda conseqüência da sedimentação da fala é a idéia de verdade, no sentido de desvelamento de uma realidade independente dos sujeitos. Por meio da linguagem, teorias explicativas dos eventos do mundo e da história do universo são formuladas. No entanto, para Merleau-Ponty, a tentativa de apresentar pela linguagem 
um estado de coisas dela completamente independente é uma expectativa gerada pela própria atividade expressiva, a qual se faz esquecer em prol daquilo que é significado (Cf. PhP, 459). A linguagem nos dirige diretamente para os referentes dos termos usados e apaga o fato de que a delimitação de tais referentes ocorre por meio dos recursos lingüísticos disponíveis. Para Merleau-Ponty, não se tem acesso a um universo pura e simplesmente independente dos sujeitos, mas sempre a uma apresentação particular da realidade decorrente de um determinado uso das significações lingüísticas.

As duas conseqüências da sedimentação da linguagem (as idéias de um pensamento e de uma verdade independentes dos meios de expressão) devem ser matizadas como ilusões necessárias do processo de funcionamento da linguagem. Afinal, segundo a Fenomenologia da Percepção, não há um pensamento transcendente à fala (que essa tentaria traduzir) nem acesso teórico a uma realidade absolutamente independente da referência lingüística. Em suma, essas duas idéias devem ser tomadas como resultados da atividade expressiva e devem remeter a essa atividade como sua condição de possibilidade.

\section{O problema do sentido gestual das palavras}

A subseção anterior mostra que a Fenomenologia da Percepção já antecipa o estudo da linguagem como fundante do saber intersubjetivo e da noção de verdade, tal como Merleau-Ponty desenvolve nos anos cinqüenta. No entanto, tal análise padece de dificuldades reconhecidas pelo próprio autor. No Visível e o Invisível, o filósofo afirma que a ligação entre os capítulos sobre o cogito e sobre a linguagem da Fenomenologia da Percepção não foi bem feita (Cf. VI, 227, fev. 59). Tentemos entender tal juízo. Segundo a Fenomenologia da Percepção, sob a atividade subjetiva exprimida em formulações predicativas (pelas quais o sujeito pode se referir linguisticamente a si mesmo), há um contato pré-reflexivo da consciência perceptiva consigo própria anterior à linguagem. Na Fenomenologia da Percepção, esse contato é imprescindível para que o sujeito unifique todos os seus atos perceptivos particulares, pelos quais se engaja nas situações mundanas. Se o sujeito "se ignorasse, ele seria, com efeito, uma coisa, e nada poderia fazer com que ele em seguida se tornasse consciência" ( $\mathrm{PhP}, \mathrm{p} .463)$, defende o filósofo. Desse modo, todos os atos perceptivos são remetidos a um pensamento geral tácito (Cf. PhP, 459), ou, do contrário, não haveria subjetividade (no sentido de um foco de ações presentes a si mesmas), já que essa se reduziria a um agregado de eventos 
causais $^{5}$. Desse ponto de vista, o cogito tácito (compreendido como uma experiência silenciosa de si mesmo enquanto ser consciente) funda todos os engajamentos particulares da consciência. Desde então, a expressão lingüística somente continua a atividade perceptiva e a esta remete como seu fundamento ${ }^{6}$. Merleau-Ponty sugere, dessa maneira, que todas as significações linguiísticas decorrem da experiência perceptiva silenciosa ${ }^{7}$. Dessa perspectiva, a linguagem se torna um veículo secundário, uma tradução de uma apreensão imediata do sentido das vivências pela consciência perceptiva $^{8}$.

Essa análise do cogito tácito soa incompatível com o capítulo "O corpo como expressão e a fala", segundo o qual a linguagem condiciona a referência da consciência a si mesma. Nesse capítulo, Merleau-Ponty repudia a idéia de um pensamento geral tácito, pois defende que todo pensamento se constitui pela mobilização das significações disponíveis rumo a um sentido novo ${ }^{9}$. A idéia de que haveria um tal pensamento tácito, um contato imediato de si consigo é, desse ponto de vista, uma ilusão decorrente do acesso imediato aos pensamentos já sedimentados. Mas esse acesso não implica haver uma síntese dos pensamentos prévia à linguagem. Na verdade, conforme tal perspectiva, o sujeito toma contato paulatinamente com seus pensamentos, à medida que os constrói por meio do exercício interminável da expressão, e esse contato não tem seu sucesso antecipado por uma consciência silenciosa geral que garantiria de antemão o sentido de todos os atos expressivos particulares.

Como se vê, por um lado, Merleau-Ponty defende que um pensamento silencioso funda a linguagem e atribui sentido às palavras; por outro, o autor expõe que é a expressividade lingüística que possibilita tal pensamento silencioso. Cabe aqui perguntar por que o autor chega a esse tratamento paradoxal da linguagem na Fenomenologia da Percepção. Para responder, notemos que o filósofo defende haver na linguagem diferentes níveis especializados de significação. Seria assim possível, por

\footnotetext{
5 "Minha visão, por exemplo, é bem 'pensamento de ver' se por isso se quer dizer que ela não é simplesmente uma função como a digestão ou a respiração, um feixe de processos recortados em um conjunto que acontece ter um sentido, mas que ela mesma é este conjunto e este sentido, essa anterioridade do futuro em relação ao presente, do todo em relação às partes" (PhP, 463).

6 "Temos a experiência de nós mesmos, desta consciência que somos, é sobre essa experiência que se medem todas as significações da linguagem e é ela que faz com que a linguagem justamente queira dizer algo" (PhP, X).

7 A linguagem "pressupõe uma consciência da linguagem, um silêncio da consciência que envolve o mundo falante e no qual primeiramente as palavras recebem configuração e sentido" (PhP, 462).

${ }^{8} \mathrm{Na}$ consciência perceptiva, "vê-se aparecer não somente o que as palavras querem dizer, mas também o que as coisas querem dizer" ( $\mathrm{PhP}, \mathrm{X})$.

9 "O pensamento não é nada de 'interior'. Ele não existe fora do mundo e das palavras" (PhP, 213).
} 
exemplo, diferenciar o puro material sonoro, a intenção verbal (ou a "fisionomia" pela qual a palavra é apreendida) e o conceito veiculado pelos vocábulos (Cf. $\mathrm{PhP}, 227)$. Essa distinção torna compreensível certas patologias em que os doentes conseguem ler um texto embora não o entendam (Cf. PhP, 212). Nesse caso, embora tenham perdido a camada conceitual da linguagem, esses doentes ainda contam com a fisionomia existencial da linguagem. Essa fisionomia das palavras seria a camada originária de significação, camada pela qual as palavras podem ser reconhecidas por seu valor emotivo ou por induzirem uma certa mímica gestual da sua pronúncia ( $\mathrm{Cf}$. $\mathrm{PhP}, 212)$. Merleau-Ponty defende que é por meio desse sentido gestual ou emotivo que a expressividade criadora da fala se manifesta ${ }^{10}$. Assim, a criação de sentido não ocorre diretamente sobre os conceitos, mas no nível da significação gestual ou emotiva da linguagem, a qual é diretamente modulada pela fala e transformada então em resultados inéditos.

Como tal significação gestual ou emotiva se forma? Segundo Merleau-Ponty, trata-se da expressão verbal de situações vividas pelo corpo. A palavra "granizo", exemplifica o filósofo (Cf. PhP, 461-2), exige uma determinada modulação do aparelho fonador para ser pronunciada. O sentido de tal palavra, correlato a tal "gesticulação" verbal, não é senão o modo como o objeto referido é apreendido pela experiência humana $^{11}$. Por conseguinte, o sentido gestual das palavras (aquele que permite a produção de significações inéditas) corresponde a padrões da experiência muda do corpo.

Merleau-Ponty estende essa análise e julga resolver o espinhoso problema da origem histórica da linguagem por meio do sentido gestual. Cada língua teria surgido de "um sistema de expressão muito reduzido mas tal que, por exemplo, não seria arbitrário chamar de luz a luz se se chama de noite a noite" (PhP, 218). Esses vocábulos primitivos da linguagem exprimiriam a essência emocional de experiências típicas com que o corpo se defronta. Assim, ao menos em seu início, as línguas não seriam formadas por vocábulos arbitrários, mas por palavras que figurariam diretamente as situações vividas.

\footnotetext{
10 "Nós descobrimos sob a significação conceitual das palavras uma significação existencial, que não é somente traduzida por elas, mas que as habita e é delas inseparável" (PhP, 212). "A significação conceitual se forma por antecipação a partir de uma significação gestual que, ela, é imanente à fala" (PhP, 209).

${ }^{11}$ Merleau-Ponty cita o "espanto diante destes grãos duros, friáveis e dissolventes que caem prontos do céu" (PhP, 462) como componentes do sentido de "granizo".
} 
Dificilmente essa hipótese da origem das línguas pode ser testada, uma vez que não há registros que comprovem se as línguas realmente se originaram como um reduzido sistema expressivo ligado diretamente à experiência. Os exemplos apresentados por Merleau-Ponty pouco convencem, já que "luz" e "noite" são vocábulos contemporâneos cujas transformações lingüísticas podem ser acompanhadas, e não palavras originárias, pelas quais os primeiros falantes exprimiram sua vivência do mundo. Permanece, ao menos, a sugestão geral de Merleau-Ponty de que certas palavras, ainda que posteriormente modificados pelo uso, podem exprimir diretamente certas experiências típicas do corpo. As experiências assim exprimidas comporiam o sentido gestual ou emotivo das palavras. Julgamos tal tese bastante problemática, pois, segundo ela, a camada de significação a que se atribui a capacidade expressiva (capacidade que não seria condicionada por nenhum pensamento anterior à linguagem) é justamente aquela que depende da consciência silenciosa do corpo para ser formada. Assim, a propriedade de criação de pensamentos concedida por Merleau-Ponty à expressividade lingüística não pode ser coerentemente compreendida, já que o meio pelo qual tal expressividade realizar-se-ia (o sentido gestual ou emotivo) é apresentado como uma tradução do pensamento silencioso da consciência perceptiva. Daí o caráter paradoxal da análise da linguagem pela Fenomenologia da Percepção: Merleau-Ponty oscila entre a autonomia do poder expressivo e seu condicionamento pela consciência silenciosa porque atribui essas duas características incompatíveis à mesma camada da linguagem, aquela do sentido gestual ou emotivo.

Julgamos que a dificuldade da Fenomenologia da Percepção (apontada por $O$ Visível e o Invisível) em harmonizar expressividade lingüística e consciência silenciosa não se resolve. Em nossa leitura, Merleau-Ponty só chega a formular uma reflexão coerente acerca das relações entre ambas após estudar a lingüística de Saussure, como veremos em seguida.

\section{B) Apropriação da lingüística de Saussure}

\section{O escopo da expressividade}

Ao acentuar o poder da expressividade lingüística e conceber de uma nova maneira (não como tradução direta) o enraizamento sensível da linguagem, os estudos desenvolvidos por Merleau-Ponty nos anos cinqüenta dissolvem o paradoxo das análises 
da Fenomenologia da Percepção sobre a atividade lingüística ${ }^{12}$. Nesta seção, acompanharemos essa ênfase na expressividade, e na próxima exporemos como Merleau-Ponty articula linguagem e experiência silenciosa.

Em 1951, o filósofo anuncia que escreve um livro sobre o poder expressivo da linguagem na literatura (Cf. PII, 44). Com essa opção, Merleau-Ponty apela a um âmbito em que a expressividade criadora é bastante visível, de modo a ser mais fácil caracterizá-la. No resumo do curso Investigação sobre o uso literário da linguagem, ministrado em 1952-3, o filósofo lamenta que a maioria das reflexões sobre a linguagem considere excessivamente os enunciados prontos e ignore, por conseguinte, a função criativa da linguagem, pela qual uma significação nova se instala e reorganiza o uso dos signos antigos (Cf. RC, 22). Dado que tais enunciados são o registro sedimentado dessa função criativa, se se limita a estudá-los, perde-se então o fenômeno central da atividade lingüística. Por sua vez, tal fenômeno se manifesta de modo patente na literatura, já que longe de se limitar a enunciar idéias pré-concebidas, os escritores, crê Merleau-Ponty, realizam uma intenção expressiva que só se estabelece de fato posteriormente à escrita. Desse modo, ao estudar a expressão literária, o filósofo pretende exibir claramente a expressividade lingüística, a qual poderia ser subestimada caso se estudasse apenas os enunciados exatos. Pretende-se partir do âmbito em que a instauração expressiva de sentido é inegável para então revelar a vigência de tal expediente mesmo em usos lingüísticos aparentemente alheios à criação expressiva, tais como aquele do algoritmo matemático. Esse é o projeto a que Merleau-Ponty se dedica em A Prosa do Mundo, escrito entre 1951-2, mas só publicado postumamente.

Como as obras literárias realizam a virtude expressiva da linguagem? Por um lado, julga Merleau-Ponty, os próprios escritores não dominam previamente aquilo que escreverão, mas delimitam paulatinamente um novo campo de significações pelo uso criativo da linguagem: das expressões sedimentadas extraem-se novas significações. Por outro, esse uso também vigora quando da leitura das obras. Obviamente os leitores estão inseridos na língua em que a obra foi escrita. Começa-se a leitura com base no sentido comum das palavras. Porém, ao menos na leitura das grandes obras literárias, lentamente ocorre um desvio da designação ordinária das palavras, e o livro atribui um sentido inédito a alguns vocábulos. Muitas palavras ou expressões comuns que

\footnotetext{
${ }^{12}$ Em uma nota de $O$ Visível $e$ o Invisível, Merleau-Ponty resume a sua solução final ao paradoxo da linguagem presente na Fenomenologia da Percepção: "o que eu chamo cogito tácito é impossível. Para ter a idéia de 'pensar' (no sentido de 'pensamento de ver e de sentir') (...), para voltar à imanência e à consciência de... é necessário ter palavras" (VI, 222, jan. 59).
} 
estabelecem a comunicação banal entre os falantes sofrem, por meio do trabalho do escritor, um tipo de torção expressiva. Esboça-se, por conseguinte, um sentido que jamais tinha sido formulado, de modo que, por fim, a leitura amplia o campo significativo do leitor ${ }^{13}$.

Merleau-Ponty nota que, uma vez realizado, o processo expressivo se apaga. As novas significações se sedimentam e são assimiladas de tal forma pelo leitor que nele pode surgir a ilusão de que o livro foi compreendido com seu sistema de significações prévio àquela leitura. De fato, essa ilusão é alimentada pelo movimento expressivo da linguagem, o qual elimina seus traços em prol das significações constituídas, as quais passam a ser referidas de maneira imediata, independentemente do processo pelo qual foram criadas (Cf. PM, 15). O esquecimento de que a expressão é a matriz dos vocábulos disponíveis leva a uma concepção da linguagem como mero instrumento de um sistema de significações puramente intelectuais, que seriam somente traduzidas pelos signos lingüísticos (mas não criadas por meio do seu uso). Segundo tal concepção, o leitor de uma obra literária (ou mesmo o participante de um diálogo) conta previamente com o sistema de significações que permite decodificar todas as combinações de vocábulos apresentadas pelo texto (ou pelo interlocutor). Por conseguinte, só se compreenderia aquilo que já se sabia antecipadamente, e a linguagem não seria senão um meio para veicular significações já claramente possuídas pelos sujeitos (Cf. PM, 12-13).

Para Merleau-Ponty, a noção de algoritmo, tal como ela é comumente apresentada pelas ciências exatas, exemplifica essa concepção de uma linguagem que prescinde do processo expressivo. O algoritmo seria um conjunto de procedimentos de cálculo para solucionar certos problemas típicos. A fim de alcançar tais soluções, partirse-ia de definições iniciais claras dos dados ou relações em questão, os quais seriam associados a signos arbitrariamente escolhidos. Em seguida, seriam definidas as operações necessárias para a solução dos problemas em vista e estabelecer-se-ia um método claro para sua aplicação. Parece aqui não haver nada de implícito no uso da linguagem, já que todo novo resultado seria deduzido dos princípios assumidos anteriormente de maneira explícita. Desse modo, parece não haver, no caso do algoritmo, possibilidades expressivas nos signos em questão, já que supostamente eles

\footnotetext{
${ }^{13}$ Merleau-Ponty dá o seguinte exemplo, extraído da leitura de Sthendal: "eu sei, antes de ler Stendhal, o que é um patife e, portanto, eu posso compreender o que ele quer dizer quando escreve que o fiscal Rossi é um patife. Mas quando o fiscal Rossi começa a viver, não é mais ele que é um patife, é o patife que é um fiscal Rossi” (PM, 19).
} 
não poderiam veicular nada além daquilo que lhes foi associado convencionalmente. $\mathrm{O}$ sistema de signos do algoritmo seria somente um veículo de significações cujo escopo já estaria definido independentemente de tal sistema (Cf. PM, 169). Além disso, as consequiências a serem obtidas pela aplicação do algoritmo (novas significações metodicamente derivadas do sistema inicial) parecem se relacionar somente de maneira contingente com os signos usados em sua descoberta. Uma vez que se supõe que tais signos são meramente convencionais, pouco importam os termos pelos quais as novas significações são exprimidas. Essas últimas parecem subsistir independentemente de sua veiculação pelo sistema convencional algorítmico, como se fossem essências inteligíveis cujas propriedades intrínsecas seriam não construídas mas reveladas pelo instrumental lingüístico (Cf. PM, 166).

Merleau-Ponty avalia que essa interpretação essencialista do procedimento algorítmico reproduz inconscientemente uma operação própria da atividade perceptiva. Sempre limitado a perspectivas parciais dos objetos e eventos, o sujeito perceptivo não hesita em crer espontaneamente na existência de coisas independentes da percepção. Dessa maneira, a atividade perceptiva como instituição precária da abertura para as coisas é ignorada, e o sujeito se dirige diretamente para elas. Por sua vez, a suposição de que o algoritmo apenas extrai consequiências de um campo de significações ideais que preexistiria à sua formulação repõe no nível do conhecimento intelectual o movimento espontâneo perceptivo, que organiza os fenômenos como um mundo independente das perspectivas parciais pelas quais se manifesta ${ }^{14}$.

O mundo de coisas independentes anunciado pela percepção, crê Merleau-Ponty, jamais se impõe completamente aos sujeitos, pois sempre aparece de maneira parcial e limitada às estruturas da percepção humana. Por conseguinte, sempre há a possibilidade de retornar das coisas (às quais a consciência espontaneamente se dirige) aos fenômenos, ou seja, explicitar o caráter irremediavelmente subjetivo da organização da experiência. Na Fenomenologia da Percepção, tal possibilidade legitima a investigação fenomenológica da vida perceptiva (Cf. PhP, 376). Do mesmo modo, a suposição de que há um mundo de essências a ser revelado pelo algoritmo deve dar lugar à explicitação das contribuições criativas da linguagem na resolução dos problemas em causa.

\footnotetext{
${ }^{14}$ A noção de essência seria formada "no contato com e pela imitação da coisa percebida tal como a percepção nos apresenta" (PM, 173). Vale notar que Merleau-Ponty já defendia essa idéia na Fenomenologia da Percepção: "não que o pensamento geométrico transcenda a consciência perceptiva, é do mundo da percepção que eu empresto a noção de essência" $(\mathrm{PhP}, 444)$.
} 
Para realizar tal explicitação, Merleau-Ponty sugere descrever o trabalho algorítmico matemático não como desvelamento de essências autônomas, mas como exploração paulatina, por meio da aplicação de regras formais, de conjuntos de relações ${ }^{15}$. Os objetos matemáticos devem ser concebidos, assim, como séries de relações que abrem um horizonte de investigação (Cf. PM, 177). Longe de serem essências de antemão prontas, tais séries comportam transformações propiciadas por operações expressivas pelas quais o conjunto de relações iniciais seria englobado em um sistema mais amplo. Embora as futuras relações não estejam efetivamente contidas nas iniciais, o horizonte aberto por essas indica um campo de soluções pelas quais os problemas em pauta poderão ser reestruturados, quer dizer, assimilados em conjuntos relacionais mais complexos. Esse desdobramento do saber matemático (e algorítmico em geral) supõe a reordenação ou ampliação do sentido de certos signos em estruturas mais vastas, o que indica que o poder expressivo da linguagem se exerce mesmo no domínio dos signos formais matemáticos ${ }^{16}$.

\section{A expressividade e a lingüística de Saussure}

Vimos que em A Prosa do Mundo Merleau-Ponty estende o fenômeno da expressão, no qual de significações adquiridas se produz um sentido inédito, a todos os âmbitos da linguagem. Não só na fala ou na escrita literária, mas mesmo na produção de conhecimentos exatos a linguagem exerce seu poder criativo ${ }^{17}$. Merleau-Ponty pretende que a descrição das operações expressivas da linguagem não seja um conjunto de relatos subjetivos que em nada contribuem para caracterizar as propriedades objetivas da atividade lingüística. Sua estratégia para garantir o interesse ontológico das descrições fenomenológicas da linguagem é explicitar a concordância dessas análises com um estudo científico sobre o tema (no caso, a lingüística desenvolvida por Ferdinand de Saussure).

\footnotetext{
15 "Em vez de dizer que constatamos certas propriedades dos seres matemáticos, dir-se-ia mais exatamente que constatamos a possibilidade de princípio de enriquecer e de precisar as relações que serviram para definir nosso objeto, de prosseguir com a construção de conjuntos matemáticos coerentes somente esboçados por nossas definições" (PM, 171).

${ }^{16}$ Segundo Merleau-Ponty, "o essencial do pensamento matemático está nesse momento em que a estrutura se descentra, se abre a uma interrogação e se reorganiza segundo um sentido novo que, entretanto, é o sentido dessa mesma estrutura" (PM, 178).

${ }^{17}$ A Prosa do Mundo não se refere mais à fala falada e à fala falante, mas sim a uma linguagem falada, "aquela que é adquirida, e que desaparece ante o sentido do qual ela tornou-se portadora" (PM, 17), e a uma linguagem falante, "aquela que se faz no momento da expressão, que vai me fazer escorregar dos signos ao sentido" (Ibid.). Desse modo, Merleau-Ponty expande para a totalidade da vida lingüística a idéia, presente na Fenomenologia da Percepção, de uma atividade criadora de significações e de um uso reprodutivo de tais significações.
} 
Aqui Merleau-Ponty utiliza para seus estudos da linguagem um argumento semelhante aquele, exposto no capítulo anterior, pelo qual defendia haver conseqüências ontológicas inerentes à sua descrição da percepção. Quanto à percepção, Merleau-Ponty afirma que todo acesso ao ser e toda concepção teórica do ser deve passar pela experiência sensível, de modo que as estruturas perceptivas contribuem para a compreensão da realidade e não são meros efeitos de um mundo independente delas. Analogamente, crê Merleau-Ponty, a descrição da experiência da linguagem e a sua teorização pela lingüística não são independentes ${ }^{18}$. Assim, por um lado, a vivência do fenômeno lingüístico já implica certa caracterização do ser da linguagem, caracterização útil para o trabalho do lingüista. Por outro, as análises teóricas do lingüista ajudam a esclarecer alguns equívocos que poderiam desvirtuar a descrição concreta da linguagem. Vejamos nesta e na próxima subseção como as descrições fenomenológicas da expressividade favorecem a teorização lingüística. Em seguida, na subseção "crítica ao sentido gestual ou emotivo das palavras", veremos como algumas teses da lingüística auxiliam as descrições fenomenológicas.

Já acompanhamos como Merleau-Ponty estende a expressão criadora para diversos domínios da linguagem, de modo a não limitá-la apenas ao campo dos atos verbais. Notemos agora que, dessa maneira, o filósofo francês altera o sentido de uma famosa distinção proposta por Saussure, entre fala e língua. Para Saussure, a língua é um conjunto de signos depositado passivamente nos falantes e que lhes permitem exercer sua faculdade natural de linguagem ${ }^{19}$. Já a fala é um ato individual, fruto da vontade dos sujeitos, os quais se servem da língua para exprimirem verbalmente suas idéias (Cf. CLG, 30). Segundo Saussure, língua e fala são interdependentes, uma vez que o sistema lingüístico é necessário para a articulação da fala e essa é a atividade pela qual a língua é criada (CLG, 37). Desse modo, o lingüista reconhece que todas as modificações da língua se originam em criações individuais que, posteriormente assimiladas pela comunidade falante, alteram a fisionomia do sistema lingüístico (Cf. CLG, 37, 138, 231-2). Saussure descarta, entretanto, que as alterações deliberadas tenham melhor chance de serem incorporadas pela língua que aquelas casuais. Permanecem apenas as modificações assimiladas pelo uso, o qual lentamente

\footnotetext{
${ }^{18}$ No artigo "Sobre a fenomenologia da linguagem", de 1951, Merleau-Ponty assevera que o resultado das descrições fenomenológicas da linguagem "não é somente uma curiosidade psicológica", mas sim uma "nova concepção do ser" (S, 110).

${ }^{19}$ Cf. Saussure, F. de Cours de Linguistique Genérale. Edition critique. Paris: Payot, 1985, p.30, doravante citado como CLG.
} 
transforma um estado da língua em outro. Uma vez que os falantes sempre estão diante de um estado da língua e normalmente não podem coordenar mudanças que se prolongam muito além do tempo de suas vidas, para Saussure, os sucessivos estados da língua não são instrumentos em vista de alguma meta expressiva, mas sim o arranjo casual dos elementos que os constituem (Cf. CLG, 117).

Saussure rejeita que o caráter fortuito dos estados da língua implique a redução de tais estados a uma somatória incoerente de acasos históricos. Na verdade, esse autor distingue duas perspectivas sobre a língua: a diacrônica, que considera as modificações da língua no decorrer do tempo, e a sincrônica, que considera um estado sistemático da língua. Assim, para além das fatalidades diacrônicas que constituem os vocábulos, é possível considerar a língua como um sistema ordenado cujos componentes portam um sentido delimitável e coerente ${ }^{20}$.

Merleau-Ponty concorda com a tese da autonomia do sentido sincrônico em relação à sucessão diacrônica. Para ele, "a linguagem não é, no instante em que funciona, simples resultado do passado que ela arrasta atrás de si” (PM, 32). Há uma ordenação sistemática que se impõe sobre os acasos pelos quais a linguagem se organiza. Mas a concordância de Merleau-Ponty é extraída de premissas diferentes daquelas de Saussure. O fenomenólogo associa explicitamente a fala à sincronia, de modo que, para ele, o estudo de um estado sistemático da língua não é senão a análise de falas individuais sedimentadas e partilhadas pelos falantes (Cf. PM, 35) ${ }^{21}$. Ora, se um estado sincrônico é o conjunto ordenado das falas de um determinado período, então tal estado não será assim tão fortuito quanto Saussure julgava. Afinal, mesmo ele admite que cada ato de fala tem um caráter intencional irrecusável (Cf. CLG, pp.30-31). Merleau-Ponty simplesmente estende a intenção expressiva que governa as falas individuais para o sistema sincrônico em geral. Assim, para o filósofo, a mútua vontade de compreensão dos falantes coordenaria, ao menos em certa medida, as alterações aleatórias diacrônicas. Os acasos objetivos que rompem a unidade de um estado

\footnotetext{
${ }^{20}$ Embora acentuasse que a oposição entre essas perspectivas "se impõe o mais imperiosamente" (CLG, p.116), Saussure jamais deixou de notar a dinâmica entre elas: "a cada instante, a linguagem implica ao mesmo tempo um sistema estabelecido e uma evolução; a cada momento ela é uma instituição atual e um produto do passado" (CLG, 24).

${ }^{21}$ Trata-se de uma tese já esboçada na Fenomenologia da Percepção, em que Merleau-Ponty já parece reformular a distinção entre língua e fala segundo a sua tematização do problema: "poderíamos dizer, retomando uma distinção célebre, que as linguagens, quer dizer, os sistemas constituídos de vocabulário e de sintaxe (...) são o depósito e a sedimentação de atos de fala nos quais o sentido não formulado não apenas encontra o meio de traduzir-se no exterior, mas ainda adquire a existência para si mesmo, e é verdadeiramente criado como sentido" (PhP, p.229).
} 
sincrônico seriam retomados pela intenção expressiva dos falantes, que organizaria tais acasos em um novo sistema ${ }^{22}$. Haveria, por conseguinte, uma racionalidade implícita à sucessão de estados sincrônicos, a qual seria sustentada pela intenção coletiva de manter um certo nível expressivo ${ }^{23}$.

Merleau-Ponty oferece um exemplo da ordenação expressiva dos acasos lingüísticos: na passagem do latim para o francês os elementos desagregadores do primeiro (tais quais a queda da última sílaba das palavras) se tornam elementos expressivos do segundo (a tônica na última sílaba, tão marcante no francês). Dessa maneira, a dissolução de um certo sistema de falas gera um outro, ainda mais eficaz que o anterior, julga o filósofo (Cf. PM, 49). Esse exemplo ilustra que para Merleau-Ponty as modificações do sistema sincrônico não são geradas por fatos aleatórios, mas são motivadas pela decadência de um estado sistemático da língua, cujos escombros valem como fatos brutos sobre as quais a intenção expressiva dos falantes reconstrói a sistematicidade da língua. As mudanças sincrônicas não seriam, desse modo, fortuitas, mas respostas à perda de expressividade de uma língua.

Deve-se notar que Merleau-Ponty não propõe que desde a origem das línguas os seres humanos mantêm o mesmo nível expressivo ou o aumentam progressivamente. A tese defendida é que há uma "história interior que de sincronia em sincronia dá um sentido comum ao menos a certos ciclos de desenvolvimento" (PM, 36). Assim, somente durante determinados períodos históricos, como a passagem do latim ao francês, seria possível notar a composição de um novo sistema que recupera e mesmo expande o potencial expressivo do anterior. Nesses ciclos históricos auspiciosos, cada um dos momentos sincrônicos suceder-se-ia projetando seu nível expressivo de maneira a definir um campo de transformações prováveis pelas quais o novo sistema sustentaria ou até mesmo ampliaria a capacidade expressiva dos anteriores (Cf. PM, 34) ${ }^{24}$.

\footnotetext{
22 "O que sustenta a invenção de um novo sistema de expressão é o impulso dos sujeitos falantes que querem se compreender e que retomam como uma nova maneira de falar os escombros usados de um outro modo de expressão" (PM, p.50).

23 "A linguagem seria então não uma Gestalt do instante, mas uma Gestalt em movimento, evoluindo para um certo equilíbrio e capaz aliás, uma vez obtido esse equilíbrio, de perde-lo em seguida como que por um fenômeno de desgaste e de buscar um novo equilíbrio em uma nova direção" (PPE, 85).

${ }^{24}$ Essa manutenção do equilíbrio expressivo por meio de uma retomada (sempre falível) dos acasos desagregadores em novas formas de racionalidade sugere, segundo Merleau-Ponty, uma noção geral de história. O desenvolvimento histórico não seria, assim, nem a manifestação de uma lógica oculta nem uma sucessão de acasos sem nexo, mas a instauração de certas linhas de força conforme uma vontade geral difusa de coexistir (Cf. PPE, 86).
} 


\section{Dois problemas da lingüística saussuriana}

Merleau-Ponty considera, vimos há pouco, que uma intenção comunicativa coordena, ao menos em certos períodos, as mudanças nas línguas. Tentaremos mostrar agora que com tal concepção é possível esboçar uma solução para dois problemas da lingüística de Saussure.

a) O primeiro se refere ao papel das falas individuais nas mudanças da língua. Saussure enumera alguns processos pelos quais as modificações linguiísticas ocorrem no decorrer do tempo. Há as mudanças fonéticas, que, por um lado, enfraquecem os laços entre as palavras e apagam seus elementos formadores (e. g., em latim inimicus pode ser analisado como junção do prefixo in a imicus; já o termo francês ennemi, derivado por alteração fonética do primeiro, não comporta análise semelhante). Por outro lado, tais mudanças por vezes aproximam grupos de vocábulos pela formação de correlações entre determinados sons (e. g., em alemão há a alternância e:i, que marca a passagem de algumas formas verbais infinitivas para suas respectivas formas passadas: beissen biss; leiten - litt). Há também a etimologia popular, deformação forçada das palavras para acomodá-las aos elementos que se crê nelas encontrar (e. $g .:$ do francês aventure surge o alemão Abenteuer, logo equivocadamente associado a Abend, noite). Outro processo é a aglutinação ou solidificação de dois termos frequentemente pronunciados em seqüência (e. g.: tous jours - toujours) (Cf. CLG, p.218).

Cumpre agora analisar o papel da analogia, aparente fonte de criatividade da língua, já que por meio dela um número indefinido de sintagmas (termos a serem proferidos) pode ser forjado. Um sintagma analógico seria formado à imagem de outro conforme uma regra determinada (e. g., oratorem $:$ orator $=$ honorarem $: \mathrm{X}$; esse $\mathrm{X}$ será honor). Para Saussure, a analogia favorece a regularidade na produção de vocábulos, de modo a compensar a desorganização da língua gerada por certas variações fonéticas e pela etimologia popular (Cf. CLG, 222). Saussure afirma, entretanto, que os fenômenos analógicos "não são mudanças" (CLG, p.223), pois a inovação surgida não é exatamente uma alteração de algo anterior, como ocorre nas variações fonéticas, mas somente a explicitação de um vocábulo por meio de uma regra vigente na língua. É verdade que Saussure considera a analogia como um fenômeno ao menos parcialmente psicológico, pois seus resultados são da ordem da fala. No entanto, para ele, trata-se primordialmente de um fenômeno gramatical, independente da consciência subjetiva. Assim, quanto aos resultados da analogia (o aspecto psicológico, subjetivo desse fenômeno), Saussure os considera como mera vocalização de 
sintagmas. Essa vocalização é considerada insignificante se comparada com o processo gramatical inconsciente que a precede e a torna possível (Cf. CLG, 227). Nesse processo, os tipos sintagmáticos em vigor na língua servem de modelo para a expressão de idéias (por exemplo, em português o prefixo "in” e o sufixo "vel” geralmente indicam ação ou evento que não pode ser realizado, tal como se nota nos vocábulos “indelével”, “incoercível”, “impossível”). Assim, para Saussure, a intenção expressiva individual se molda inconscientemente aos parâmetros lingüísticos disponíveis (e. g.: para expressar que um plano econômico de governo era inalterável, um antigo ministro brasileiro denominou-o "imexível”, seguindo, desse modo, os princípios morfológicos em vigor no português). Segundo o lingüista, essa necessária acomodação das intenções expressivas às possibilidades gramaticais disponíveis indica que a produtividade analógica ocorre na própria língua enquanto sistema sedimentado inconscientemente nos falantes, como se tal sistema pré-determinasse as linhas gerais da sua evolução. As falas são, desse ponto de vista, realizações contingentes do sistema da língua, o qual acaba por delimitar antecipadamente todas as possibilidades da expressão individual.

Como ocorreria tal delimitação? Saussure defende que simultaneamente a cada fala subsistem diversas séries inconscientes, em que os vocábulos pronunciados são associados a inúmeros outros (Cf. CLG, 178). Ao se pronunciar qualquer palavra, haveria, dessa maneira, relações inconscientes que a associariam a diferentes vocábulos, seja por analogia de significado ou de imagem acústica, ainda que esses últimos nunca tenham sido realmente pronunciados e nem jamais o sejam. Essas relações associativas não dependem da fala e, virtualmente, contêm todas as suas futuras criações. Assim, Saussure considera que a analogia não altera o sistema sincrônico (Cf. CLG, 223), pois, de fato, todas as futuras associações já valem como possibilidades inconscientemente ligadas aos sintagmas efetivamente falados. Desse ponto de vista, as "criações" analógicas são, na verdade, meras atualizações de virtualidades pré-determinadas. Por conseguinte, Saussure, que de início afirmara que a fala é a fonte pela qual a língua é criada (Cf. CLG, 37), acaba por defender que no caso da analogia (em que aparentemente havia criação subjetiva e não somente contingências de pronúncia ou confusões, como nos respectivos casos de mudanças vocálicas e etimologia popular) a fala nada produz e não é senão o veículo de manifestação de virtualidades do sistema lingüístico, as quais já delimitam previamente a amplitude significativa de todos os vocábulos possíveis. Ficamos, desse modo, sem entender como a fala realiza a sua virtude criadora. 
b) O segundo problema é aquele da compreensão entre os falantes. Saussure defende que o sentido dos termos não é uma propriedade inerente a cada palavra, mas sim fruto das relações entre os diversos vocábulos de uma língua. Essa é a hipótese do caráter diacrítico dos signos lingüísticos, a qual exporemos com mais detalhe na próxima seção. Essa apresentação sumária do diacrítico nos basta ao menos para apresentar uma dificuldade que de imediato dele decorre. Se o sentido de cada termo depende da sua relação com os demais, então parece ser necessário que haja uma coincidência perfeita do conjunto de oposições lingüísticas dos falantes para que eles verdadeiramente se entendam. A língua deveria ser uniformemente partilhada de modo a evitar que alguns indivíduos se sirvam de oposições semânticas que faltam a outros, o que equivaleria a encerrá-los em dialetos individuais ${ }^{25}$. Porém, com efeito, facilmente se comprova que existe uma enorme diferença de patrimônio lexical tanto entre os falantes de um mesmo idioma quanto entre as diversas fases da vida de um mesmo indivíduo. Se o sentido depende estritamente das relações opositivas de um sistema sincrônico, então falantes com sistemas levemente diferentes não se compreendem totalmente, e nenhum deles pode ter certeza de entender suas expressões de outrora, quando sabiam menos palavras.

Saussure não oferece uma resposta clara para esse problema. Uma possível solução baseada nas suas teses seria apelar para as associações inconscientes de cada falante: as analogias virtuais (que recobrem toda a potencialidade do sistema lingüístico) seriam levadas em conta na compreensão dos sintagmas proferidos e preencheriam inconscientemente os termos ausentes no léxico dos sujeitos, de maneira a permitir que todos se compreendessem. Apesar da amplitude desigual dos sistemas diacríticos individuais explícitos, todos esses sistemas individuais se igualariam em potencialidade expressiva. Inconscientemente, todos os falantes se serviriam das mesmas oposições diacríticas e, por conseguinte, se entenderiam adequadamente.

Tal solução implica que toda novidade expressiva já estaria antecipada em um pensamento inconsciente. Conseqüentemente, não haveria efetiva criação lingüística e toda comunicação seria mera ocasião para atualizar significações preexistentes. Essa concepção da linguagem se aproxima daquela, combatida por Merleau-Ponty desde a Fenomenologia da Percepção, que supõe um pensamento transcendente à fala, o qual essa última apenas traduziria. As descrições da expressividade criadora contidas nesse

\footnotetext{
${ }^{25}$ Essa dificuldade da lingüística saussuriana é apresentada por Tullio de Mauro em Une Introduction à la Sémantique. Paris: Payot, 1969, cap. V.
} 
livro e em A Prosa do Mundo são fortes contra-exemplos a esse tipo de concepção, e sugerem que um outro tipo de solução deve ser buscada para o problema da mútua compreensão entre os falantes.

A ênfase de Merleau-Ponty na expressividade lingüística aponta para uma resposta aos dois problemas expostos acima. Quanto ao primeiro, lembremos que, para Saussure, quaisquer novos sintagmas estão antecipados nas associações potenciais que constituiriam, juntamente com aqueles sintagmas efetivos, o caráter sincrônico da língua. Isso deixa a fala numa situação paradoxal: por um lado ela é apresentada como fonte das criações da língua; por outro, (se se exclui as variações fonéticas contingentes e as distorções da etimologia popular) ela meramente atualiza um sentido já antecipado pelo sistema lingüístico. Merleau-Ponty escapa desse paradoxo ao atribuir de fato função criativa à fala. Para ele, os novos vocábulos e seu ganho de expressividade são fundados pela produtividade da fala. Desse ponto de vista, dizer que todas as possibilidades expressivas já estão antecipadas inconscientemente na língua é uma ilusão retrospectiva que em nada esclarece por que alguns sintagmas são pronunciados e outros não. Na verdade, segundo a concepção de Merleau-Ponty, em vez de ser insignificante vocalização de um sistema pré-arranjado, a fala cria os sintagmas, os quais supõem como base do fenômeno expressivo outros sintagmas cristalizados na língua, mas não todos os sintagmas possíveis ordenados inconscientemente. Do contrário, como entender que apenas alguns dos supostos sintagmas já inconscientemente formados se manifestam? O que tornaria a manifestação desses mais provável que a de outros? A tese de Merleau-Ponty escapa dessas dificuldades: os sintagmas proferidos não figuravam em alguma camada inconsciente mas são verdadeiramente produzidos pela fala, e só então passam a fazer parte do sistema da língua.

Quanto ao segundo problema, Merleau-Ponty defende que a fala dirigida por um sujeito a outro não é significativa apenas porque o ouvinte associa os termos a significações que ele já porta. Se a comunicação se reduzisse a essa remissão da experiência a um quadro de significações prévias, então nada de novo poderia ser apreendido por meio dela. Tal como aparece já na Fenomenologia da Percepção, o sentido veiculado pelas falas é "uma certa carência que procura preencher-se" ( $\mathrm{PhP}$, 214), ou seja, não está contido em seu veículo expressivo. Segundo essa concepção, o sentido não é imanente aos signos e nem mesmo ao sistema da língua considerado como 
conjunto de sintagmas em oposição ${ }^{26}$. Assim, não é preciso supor a identidade do patrimônio diacrítico dos falantes para que haja compreensão. Essa identidade pode ser, quando muito, um telos regulador, já que, para Merleau-Ponty, cada pensamento veiculado pela língua tenta justamente se fazer universalmente compreensível (Cf. PII, 43-4). O sucesso de tal tentativa não está garantido previamente por virtualidades portadoras de todas as significações possíveis de uma língua. Pelo contrário, se se devesse partir de um sistema de significações já completo de antemão, então a comunicação seria supérflua. No entanto, os sujeitos se motivam a comunicar-se justamente porque há diferentes ordenações dos vocábulos, que veiculam idéias não possuídas por todos. Comunica-se porque é possível aprender novas significações e não somente para confirmar ou meramente explicitar que virtualmente já se sabia. As significações são, desse ponto de vista, intenções esboçadas em direção às quais os falantes se dirigem, de maneira a exceder, por vezes, seu repertório semântico e a criar novos recursos expressivos. Esse processo expressivo não exige a coincidência prévia das oposições diacríticas dos falantes para ocorrer, embora possa tender para uma tal coincidência. Não se trata, assim, de supor que de início os falantes se entendem (fato para o qual há inúmeros contra-exemplos), mas sim de reconhecer que eles buscam se compreender e que tentam, para tanto, aproximar os seus sistemas de significação. Desse modo, a ausência de uma comum medida dos sistemas diacríticos individuais não é somente um empecilho para a comunicação, mas também, e principalmente, um motivador para que essa última seja construída ativamente.

\section{Crítica ao sentido gestual ou emotivo das palavras}

Acompanhamos nas duas últimas subseções como Merleau-Ponty se aproxima da lingüística de Saussure de modo a salientar o interesse teórico de suas descrições fenomenológicas da fala. $\mathrm{Na}$ verdade, longe de simplesmente filiar-se à doutrina saussuriana, o fenomenólogo a desenvolve enquanto investigação da expressividade da fala, investigação que permite resolver ao menos dois problemas da teoria saussuriana. Não se trata, porém, de criar uma ciência lingüística própria, e sim de explicitar como o estudo objetivo da linguagem pode ser beneficiado ao se enfatizar o papel da expressividade criadora.

\footnotetext{
26 “A linguagem, considerada parte por parte, não contém seu sentido, (...) toda comunicação supõe, naquele que escuta, uma retomada criativa do que é ouvido" (PII, 43).
} 
Mas não só a teorização sobre a linguagem é favorecida pelas descrições fenomenológicas da experiência. Outrossim, tal teorização auxilia a corrigir alguns equívocos que obsedavam a descrição fenomenológica do funcionamento da linguagem. De fato, Saussure oferece uma explicação para o modo como a linguagem significa que muito repercutirá na obra de Merleau-Ponty. Trata-se da hipótese, mencionada rapidamente acima, do caráter diacrítico dos vocábulos. Com tal hipótese, Saussure se opõe à concepção da linguagem como nomenclatura, ou seja, como um conjunto de termos ligados a referentes previamente determinados ${ }^{27}$. De certa maneira, MerleauPonty defendia uma concepção nomenclaturista da linguagem na Fenomenologia da Percepção. O sentido gestual ou emotivo das palavras, camada primeira de significação, da qual o sentido conceitual se derivaria, era apresentado como uma expressão direta de certas atitudes típicas do corpo ante o meio ambiente. Tais vivências silenciosas fundariam a linguagem e permitiriam que os falantes de diferentes línguas pudessem se traduzir (Cf. $\mathrm{PhP}, 462)$.

A hipótese do caráter diacrítico dos vocábulos leva à rejeição de que as palavras significam por rotulação de um significado delas autônomo, seja esse significado uma coisa percebida, um conceito ou mesmo uma essência emotiva apreendida pelo corpo. Segundo tal hipótese, cada palavra (e mesmo cada fonema) significa e é reconhecível por meio de suas relações com as demais palavras (ou fonemas) do sistema lingüístico. Assim, mesmo os significados dos vocábulos são determinados por relações opositivas e não correspondem a uma camada independente e pré-determinada, à qual simplesmente se atribuiria "rótulos". Saussure ilustra essa tese com o seguinte exemplo: geralmente se diz que o termo francês "mouton" ("carneiro") corresponde ao termo inglês "sheep"; mas não se trata de uma correspondência exata, como se ambos os termos nomeassem a mesma realidade independente das línguas em que são usados. Afinal, argumenta o lingüista, em inglês, "sheep" se opõe a "mutton" ("carne de carneiro preparada e servida à mesa"), uma relação entre termos que não ocorre em francês. Nessa língua, "mouton" significa tanto o animal carneiro quanto sua carne já pronta para alimentação humana. Desse modo, a extensão significativa de "mouton" e

\footnotetext{
${ }^{27}$ Vale notar que em um certo momento do Curso de Lingüística Geral, Saussure ainda se mantém preso à concepção nomenclaturista, ainda que transportada para o nível psíquico: o autor apresenta o signo lingüístico como unidade entre significante (som) e significado (conceito). Em seguida dá o seguinte exemplo: ao significado "boi" corresponderiam diferentes significantes conforme a língua ("boeuf" em francês, "ochs" em alemão, etc.) (Cf. CLG, 100). Aqui, Saussure ainda sustenta a concepção segundo a qual os vocábulos apenas rotulam uma realidade preexistente.
} 
"sheep" não é a mesma; eles não se referem a uma realidade apreendida de maneira idêntica pela língua inglesa e francesa (Cf. CLG, 160).

Para Saussure, esse exemplo evidencia que os vocábulos lingüísticos significam não por meio de algum conteúdo próprio, mas sim por causa das oposições com outros termos da língua, oposições pelas quais o seu campo semântico é determinado ${ }^{28}$. Assim, longe de ser uma coletânea de "rótulos" aplicáveis a uma realidade pré-determinada, cada língua é um sistema de oposições que impõe uma discriminação particular à experiência, discriminação que não encontra paralelo perfeito em outra língua.

Se se aceita que toda língua funciona como um sistema diacrítico, então qual o estatuto teórico do sentido gestual ou emotivo das palavras? Segundo a hipótese do sentido gestual, as palavras (ou ao menos algumas palavras) significam porque veiculam certas atitudes típicas do corpo ante o mundo. Conforme a lingüística saussuriana, esse tipo de associação de conteúdos pessoais às palavras não é o que atribui a sua significação. Afinal, o sentido emotivo dos vocábulos decorreria das vivências particulares de cada indivíduo. Ora, nada impede que os indivíduos confiram associações emotivas diversas a determinados vocábulos, conforme a singularidade de cada experiência individual. Dessa maneira, não haveria como garantir uma base de compreensão mínima para a comunicação. Para Saussure, o significado dos vocábulos não decorre de tal fonte, tão passível de discrepâncias, mas sim de sua delimitação opositiva no interior do sistema lingüístico. Vimos que as oposições diacríticas também não são uniformemente partilhadas. No entanto, os discrepantes sistemas de relações opositivas podem ser ao menos aproximados pelo aprendizado de vocábulos específicos. Já a discrepância de sentido emotivo exigiria a partilha da intensidade e especificidade de experiências individuais, o que parece bastante improvável.

Segundo a lingüística de Saussure, o sentido gestual ou emotivo se reduz a um conjunto de associações secundárias pelas quais os indivíduos relacionam determinadas vivências particulares a certos vocábulos. Mas não é por meio de tais associações que os vocábulos portam algum significado lingüístico. Nos anos cinqüenta, Merleau-Ponty parece concordar com tal tese. Em A Prosa do Mundo, a camada primordial da linguagem não é mais apresentada como o sentido gestual, conforme defendia a Fenomenologia da Percepção, mas sim como o princípio de diferenciação dos vocábulos que atua na cadeia verbal (por meio do qual as relações opositivas se

\footnotetext{
${ }^{28}$ Saussure acredita que "um termo pode ser modificado sem que se toque seja no seu sentido seja nos seus sons, unicamente pelo fato de um termo vizinho ter sofrido uma modificação" (CLG, 166).
} 
formam) (Cf. PM, 45-6). Desse ponto de vista, o sentido lingüístico se origina não da associação de um vocábulo a uma certa essência afetiva de experiências de que o corpo guarda o estilo, mas da diferenciação dos próprios vocábulos pela fala, diferenciação pela qual os campos extensionais de significação dos vocábulos são delimitados.

Para Saussure, essa diferenciação primordial dos vocábulos ocorre de maneira arbitrária. Por arbitrário, o lingüista se refere ao caráter aleatório do laço entre os significantes e os significados no sistema da língua. Os vocábulos não são fundados nem em aspectos do mundo percebido nem no privilégio de certos fonemas, e devem sua feição somente a relações opositivas casuais com os demais ${ }^{29}$. Por exemplo, diferenças fônicas ignoradas em uma língua servem para constituir relações opositivas em outra (e. g.: o "i” longo ou curto no italiano "mite” [suave] não faz diferença. Já em alemão, ele pode distinguir "Mitte" [centro] e "miete" [flexão do verbo louvar] $)^{30}$. O mesmo fenômeno ocorre em relação aos significados: os jovens humanos que em português são designados por vocábulos de gêneros diferentes, "menino" ou "menina", em alemão são indicados por uma única palavra, "Kind", de gênero neutro. Tais exemplos ilustram que a formação das palavras não responde a nenhuma exigência natural advinda quer dos sons das palavras quer dos seus referentes. A delimitação opositiva dos vocábulos se baseia somente no seu uso por uma comunidade linguiística. As línguas são arranjos contingentes de palavras, os quais revelam diferentes modos pelos quais as sociedades humanas se referem à realidade.

O caráter arbitrário do signo não deve ser compreendido como convencional. $\mathrm{Na}$ verdade, a hipótese de que as palavras se delimitam arbitrariamente é contrária à idéia de que elas tenham surgido por convenção. Afinal, se o sentido das palavras fosse estabelecido por convenção, então ele responderia a exigências racionais tais como simplicidade, ausência de equívocos, etc. (conforme ocorre na definição convencional de termos técnicos, por exemplo). Ora, não se observa que tais exigências, que regem o estabelecimento de línguas artificiais, coordenem a delimitação do sentido dos termos usados nas línguas naturais. Nessas últimas, os vocábulos são instituídos apenas por oposições mútuas casualmente estabelecidas, oposições que não excluem equívocos,

\footnotetext{
${ }^{29}$ Claro que Saussure considera uma motivação relativa quanto aos signos derivados. Por exemplo, no sistema decimal, o termo "dezenove" não é completamente arbitrário, pois segue-se de "dez" e "nove", já esses últimos termos foram forjados arbitrariamente.

${ }^{30}$ Outra evidência em favor da arbitrariedade fônica dos signos é o fato de a capacidade articulatória espontânea das crianças ser mais vasta que aquela de pronúncia dos vocábulos, a qual deve se limitar aos fonemas utilizados por sua língua. Assim, não são as possibilidades articulatórias que determinam as regras fônicas das línguas, mas o contrário, ou seja, certas regras, já arbitrariamente constituídas, delimitam a amplitude articulatória dos falantes (Cf. PPE, 24).
} 
obscuridades e que não circunscrevem os referentes segundo padrões prévios de racionalidade (os quais, por exemplo, exigiriam que os referentes devessem ser coisas individuais ou fatos isolados, etc.), mas segundo resultados fortuitos das relações opositivas ente os termos. Assim, por exemplo, não só coisas individuais são referidas pelas línguas naturais, mas situações complexas, processos, impressões fugazes, etc., ou seja, não se segue nenhum padrão racional de discriminação dos entes, mas justamente os padrões de discriminação são formados pelos vocábulos. Além disso, a hipótese de que o sentido das palavras é instaurado convencionalmente é insatisfatória, uma vez que o estabelecimento de convenções supõe alguma linguagem em funcionamento (por meio da qual os sujeitos chegariam ao acordo em vista), e, desse modo, o apelo a convenções não explica a origem do sentido dessa linguagem que possibilita as próprias convenções.

\section{C) Percepção e linguagem}

\section{A percepção enformada culturalmente}

Em diversos textos, Merleau-Ponty assimila a idéia do sentido lingüístico como fruto de relações opositivas entre vocábulos formados arbitrariamente. No artigo "A linguagem indireta e as vozes do silêncio", o filósofo afirma: "o que aprendemos em Saussure, é que os signos um a um não significam nada, que cada um entre eles menos exprime um sentido que marca um desvio de sentido entre ele mesmo e os outros" (S, 49). Em A Natureza, Merleau-Ponty admite que a linguagem se opõe "a toda predestinação dos signos a um significado: o laço não é dado (imitação), ele é criado por um princípio interno de diferenciação dos signos em uma língua” (N, 289). Essa assimilação da idéia da linguagem como sistema diacrítico implica alterar o papel da atividade perceptiva (tal como defendido pela Fenomenologia da Percepção) no funcionamento da linguagem. Afinal, longe de traduzir ou registrar uma realidade autonomamente percebida, conforme esse livro parecia defender com a tese do sentido emotivo, as línguas, segundo a concepção diacrítica, fornecem os instrumentos pelos quais determinados eventos ou coisas podem ser referidos, de modo a direcionar as capacidades discriminativas inerentes à percepção.

Merleau-Ponty chega a reconhecer essa modelação das capacidades perceptivas pela linguagem em raras passagens da Fenomenologia da Percepção. Ele afirma, por exemplo, que "a denominação dos objetos não vem depois do reconhecimento, ela é o próprio reconhecimento (...), a palavra traz o sentido e, impondo-o ao objeto, tenho 
consciência de atingi-lo" (PhP, 207). Em seguida, retoma um exemplo de A Estrutura do Comportamento (Cf. SC, 184) ao defender que "para a criança o objeto só é conhecido quando é nomeado, o nome é a essência do objeto e reside nele do mesmo modo que sua cor e que sua forma" (PhP, 207). No entanto, de modo geral, o filósofo apresenta, na Fenomenologia da Percepção, o campo percebido como um conjunto de fenômenos organizado "segundo regras próprias" $(\mathrm{PhP}, 46)$, as quais, por decorrerem de capacidades naturais (Cf. PhP, 59), produziriam conteúdos partilháveis por todos os sujeitos independentemente da língua ou cultura (Cf. $\mathrm{PhP}, 505)$.

Por sua vez, nos anos cinqüenta, Merleau-Ponty admite um certo nível de enformação cultural do campo perceptivo, em concordância, como veremos logo a seguir, com a tese saussuriana do caráter arbitrário dos signos lingüísticos. As considerações mais claras do filósofo a respeito dessa enformação se referem à pintura. Em “A linguagem indireta e as vozes do silêncio", Merleau-Ponty critica a idéia de que a perspectiva planimétrica, muito utilizada na pintura clássica, se impõe aos artistas por meio da percepção. Na verdade, tal perspectiva não seria a apresentação direta do mundo sensível, mas uma certa maneira, determinada culturalmente, de apreendê-lo, maneira que não é necessariamente exigida pelo mundo percebido, já que esse também faculta outras decodificações do campo fenomenal (expressadas, por exemplo, pelos trabalhos de Matisse, Klee e outros pintores modernos que, em muitos casos, dispensam a perspectiva planimétrica). Por conseguinte, a percepção não se limita a veicular padrões naturais de organização do campo fenomenal, mas atualiza determinados parâmetros de manifestação fenomênica culturalmente carregados (Cf. S, 61). Desse modo, mais do que revelar conteúdos universalmente partilháveis, a atividade perceptiva "projeta no mundo a assinatura de uma civilização" (PM, p.97). Quer dizer que os poderes discriminativos do aparato perceptivo não fornecem, ao menos de imediato, dados idênticos para todos os seres humanos, já que tais poderes, pelo menos até certo grau, favorecem certas discriminações no campo fenomenal decorrentes do meio cultural em que se desenvolvem. Dado que a linguagem é um dos componentes mais marcantes da cultura humana, podemos inferir que Merleau-Ponty admite, nos anos cinqüenta, que as línguas intensificam diferenças nas capacidades discriminativas de sujeitos perceptivos de contextos histórico-culturais diversos ${ }^{31}$.

\footnotetext{
${ }^{31}$ Ao expor o caráter diacrítico das línguas, Merleau-Ponty usa o seguinte exemplo: "há em certas línguas duas palavras para designar o sol, conforme se fale do sol nele mesmo ou de sua radiação sobre a Terra"
} 


\section{A articulação entre vida perceptiva e atividade lingüística}

Vimos que Merleau-Ponty reconhece a importância da linguagem e da cultura em geral na organização do campo fenomenal. No entanto, conforme relatam as atas do Colóquio de Bonneval (1960) sobre o inconsciente, para Merleau-Ponty "a abertura ao ser não é lingüística: é na percepção que ele vê o lugar natal da fala" (PII, 274). Dessa maneira, mesmo em seus anos finais, o filósofo não considera que a linguagem é a responsável pela inserção do sujeito no mundo, mas sim que ela se estabelece sobre uma abertura originalmente perceptiva. Essa posição, antes de se opor, na verdade complementa aquela defendida nos anos cinqüenta, exposta há pouco: Merleau-Ponty havia reconhecido que a vida perceptiva sempre veicula a marca de uma civilização, marca que provavelmente incluía certos padrões discriminativos favorecidos por determinados vocábulos ou expressões lingüísticas. No entanto, tal como o filósofo acentua em 1960, essa veiculação não é absolutamente autônoma e depende da abertura perceptiva ao ser. Vamos tentar esclarecer o que significa tal dependência e, no geral, como vida perceptiva e vida lingüística se articulam.

É preciso notar, de início, que Merleau-Ponty sempre considera a linguagem um tipo de intencionalidade corporal. Essa tese, exposta já na Fenomenologia da Percepção, permanece no decorrer dos anos cinqüenta ${ }^{32}$. Lembremos do exemplo da passagem do latim para o francês. Não se trata de um decreto dos sujeitos falantes, pois tais eventos são por demais hesitantes para assim se definirem. Porém, são também muito sistemáticos para que se reduzam a uma justaposição de acontecimentos aleatórios. Ocorre que os diversos acasos pelos quais uma língua se desarticula, tais como a queda da última sílaba das palavras, organizam-se como elementos de um novo sistema expressivo (no caso, a tônica na última sílaba das palavras), que restabelece ou mesmo amplia as possibilidades comunicativas ameaçadas pela decadência da primeira. Ora, a retomada de acasos factuais e sua transformação em um campo significativo é o modo como Merleau-Ponty descreve a atividade corporal (Cf. PhP, 226). O corpo responde às situações mundanas projetando uma forma significativa sobre os estímulos.

(PPE, 83). Assim, certas línguas contribuem para a percepção do sol como um fator agente sobre o planeta, enquanto outras favorecem sua apreensão como um objeto.

${ }^{32}$ Cf. S, 111. Assim, mesmo com a apropriação da lingüística de Saussure, Merleau-Ponty mantém o enraizamento corporal da linguagem. (Cf. Thierry, Y. Du corps parlant. Le langage chez Merleau-Ponty. Bruxelles: Ousia, 1987, p.34). 
Do mesmo modo, a intencionalidade expressiva responde aos acasos lingüísticos ao constituir novas maneiras de se comunicar.

Apesar de a linguagem ser considerada por Merleau-Ponty uma intencionalidade corporal, tal qual a percepção, não é possível afirmar que ambas forneçam conteúdos homogêneos. Surge daí o problema da articulação entre vida perceptiva e expressão lingüística. Certamente é preciso haver dados perceptivos, uma experiência do mundo, para que o princípio discriminativo da fala atue de modo a elaborar um sistema de oposições lingüísticas. No entanto (conforme ensina a linguiística saussuriana, que Merleau-Ponty, ao menos nesse ponto, parece seguir ${ }^{33}$ ), a experiência perceptiva não determina quais signos serão formulados e nem o seu significado. Se se aceita a tese do arbitrário do signo, então as vivências sensíveis (e mesmo afetivas) não condicionam os significados lingüísticos e a articulação entre esses e as primeiras não ocorre como simples tradução ou registro dessas vivências nos vocábulos, conforme a Fenomenologia da Percepção parecia propor por meio da tese do sentido gestual das palavras. A auto-organização do campo fenomenal e as vivências corporais não determinam o sentido das palavras, pois essas se formam segundo um princípio de mútua oposição que é indeterminado em relação aos conteúdos percebidos. Não há, assim, homogeneidade entre conteúdo percebido e falado, já que as diferentes línguas instituem diferentes possibilidades referenciais em relação ao campo perceptivo. $O$ problema é então esclarecer como a vida perceptiva e a vida expressiva do sujeito podem se conciliar. A dificuldade, como Merleau-Ponty admite até em seus textos finais, é que por meio de um simbolismo arbitrário, a linguagem instaura um contato com o mundo aparentemente heterogêneo àquele instituído pela percepção ${ }^{34}$. No entanto, embora os sistemas lingüísticos não sejam determinados pela organização dos conteúdos do campo fenomenal, eles pressupõem essa última (conforme a fala de Merleau-Ponty no colóquio de Bonneval), de modo que alguma relação de continuidade entre ambos deve haver.

Uma vez rejeitada que a articulação entre percepção e linguagem se dê por um tipo de tradução direta dos conteúdos da primeira pela segunda, como esclarecer a relação entre ambas? Mauro Carbone defende que a relação entre percepção e

\footnotetext{
${ }^{33}$ Tal como a citação de $A$ Natureza nas páginas setenta e cinco confirma.

${ }^{34}$ Segundo as notas de $O$ Visível e o Invisível, é o mesmo sujeito encarnado "que percebe e que fala" (VI, 252 , set. 59). No entanto, as diferenças entre ambas as funções levam Merleau-Ponty a afirmar o seguinte: “o que é preciso esclarecer: a perturbação introduzida pela fala no Ser pré-lingüístico” (VI, 252, set. 59).
} 
linguagem é aquela de uma homogeneidade formal entre ambas ${ }^{35}$. Progressivamente, Merleau-Ponty teria interpretado que a estrutura figura/fundo, pela qual a percepção se organiza, funciona tal qual uma série de oposições diacríticas. Analogamente aos vocábulos, cada figura percebida só se delimitaria por sua relação opositiva com os elementos do fundo do qual ela é segregada. Segundo Carbone, essa interpretação "é o que permite [a Merleau-Ponty] abandonar a tendência (...) de conceber a vida irrefletida e silenciosa da consciência como fundo positivo de sentido em relação ao qual a linguagem se apresenta como segunda e derivada" 36 . Na verdade, haveria uma "forma diacrítica comum"37 à experiência silenciosa e à linguageira; ambas organizam similarmente os seus dados, de modo a constituir uma experiência significativa por meio de relações opositivas entre seus respectivos dados ${ }^{38}$.

A tese de uma homologia estrutural entre percepção e linguagem garante que a primeira não funciona de maneira completamente diferente da segunda. Ambas atualizam um modo típico pelo qual o corpo organiza uma experiência significativa, a saber, não por atribuição direta de sentido a conteúdos autônomos, mas por um princípio de diferenciação relacional de dados que atua seja nas habilidades perceptivas seja na cadeia verbal. Tal tese revela, assim, a unidade formal de diferentes intencionalidades corporais. No entanto, ela não esclarece como percepção e linguagem de fato se relacionam. A homologia estrutural entre ambas por si só não explica como os conteúdos percebidos são exprimidos lingüisticamente. Que a percepção se organize indiretamente, por um conjunto de oposições entre tema percebido e fundo, pouco elucida o funcionamento da linguagem em relação a ela, já que as diferenciações arbitrárias da cadeia verbal não correspondem exatamente a nenhum padrão de diferenciações perceptivas. O simples fato de que há diferentes línguas cujas oposições internas não são equivalentes revela que elas não seguem alguma diferenciação diacrítica fundante supostamente oferecida pela percepção. Assim, mesmo que se admita que a atividade lingüística e a perceptiva signifiquem por meio de conjuntos de

\footnotetext{
${ }^{35}$ Cf. Carbone, M. "La dicibilité du monde. La période intermédiaire de la pensée de Merleau-Ponty à partir de Saussure". In: VV.AA. Merleau-Ponty - le philosophe et son langage. Paris: Vrin, 1993.

${ }^{36}$ Ibid., p.98.

${ }^{37}$ Ibid., p.99.

38 A interpretação de Carbone é consistente com os textos de Merleau-Ponty. O filósofo afirma, por exemplo, que "a análise saussuriana das relações entre significantes e das relações de significantes à significados e de significações como diferenças de significações confirma e reencontra a idéia da percepção como desvio em relação a um nível" (VI, 252, set. 59). Assim, para Merleau-Ponty, a percepção é "sistema diacrítico, relativo, opositivo" (VI, 263, out. 59), e, nesse sentido, como afirma em A Natureza, "a vida da linguagem reproduz em um outro nível as estruturas perceptivas" (N, 274).
} 
oposições, não se segue que tais conjuntos se recubram perfeitamente ou se codeterminem harmoniosamente. Resta ainda esclarecer como o campo perceptivo e a atividade lingüística efetivamente se articulam.

\section{A fixação dos dados sensíveis pela linguagem}

Como notamos na subseção anterior, Merleau-Ponty caracteriza a ordenação própria à vida perceptiva como diacrítica. Quer dizer que a experiência sensível não é a assimilação de significações silenciosas positivas. Concebida como estrutura diacrítica, a experiência não fornece senão um conjunto de desvios, de intervalos e de descontinuidades entre os componentes sensíveis dos objetos percebidos, e entre esses e o horizonte sobre o qual se perfilam. Assim, os dados percebidos não portam em si mesmos um sentido, mas o constituem por mútua oposição. Essa tese traz consequiências para a investigação ontológica pretendida por Merleau-Ponty: a experiência perceptiva não oferece um acesso direto ao ser sensível que motiva a percepção, tal como a Fenomenologia da Percepção parecia supor. Nesse livro, Merleau-Ponty admite que a percepção reconstitui o ser exterior que a motiva (Cf. PhP, 240). Tal reconstituição manifestava de maneira bastante satisfatória as propriedades e estruturas do mundo. Com a interpretação diacrítica da percepção, Merleau-Ponty parece admitir que a reconstituição do ser pela experiência não expõe diretamente as propriedades do ser, mas depende de relações opositivas entre os dados sensíveis. Essas relações, por sua vez, não são sempre as mesmas para todos os sujeitos em todos os tempos, já que podem ser favorecidas por hábitos culturais não partilhados universalmente, tal como sugerimos há pouco.

Vimos que a percepção ordena a apresentação do mundo sensível de modo indireto. Além disso, deve-se considerar que os conteúdos percebidos não são simplesmente traduzidos pela linguagem, mas expressos por esse outro sistema diacrítico, ou seja, pelas oposições lingüísticas (responsáveis pelas significações linguageiras). Como essa expressão ocorre? Para Merleau-Ponty, a relação efetiva entre percepção e linguagem é de fixação da última pela primeira. "Falar ou escrever é bem traduzir uma experiência, mas que só se torna texto pela fala que ela suscita" (RC, 41), afirma o filósofo no resumo do curso O Problema da fala, ministrado em 1953-4. Quer dizer que embora a linguagem suponha a abertura perceptiva originária, essa última não deve ser concebida como um núcleo de vivências duráveis e diretamente disponíveis aos sujeitos perceptivos. Afinal, a própria percepção, conforme já acentuamos, se ordena 
como sistema de significações indiretas. Os conteúdos percebidos não são significações silenciosas simples às quais se aplicaria rótulos verbais; tais conteúdos só são delimitados enquanto tais por meio de sua expressão em signos lingüísticos partilháveis e sedimentáveis. Assim, não basta afirmar que a linguagem é fundada pela experiência perceptiva; é preciso também acentuar que a linguagem é um poder intencional que transfigura as fugidias experiências sensíveis (que estão em sua base) em idealidades culturais. A expressão da experiência sensível por meio de vocábulos sedimentados e partilhados torna possível a um sujeito tanto desvelar a sua vida silenciosa particular aos demais sujeitos que comungam do mesmo código lingüístico quanto apreender a experiência sensível dos outros falantes (Cf. PM, 122).

É só dessa maneira que a universalidade do sentir, admitida por Merleau-Ponty em A Prosa do Mundo (conforme mencionamos no início deste capítulo), de fato se realiza. Por meio das palavras, um sujeito transmite a outros a sua experiência perceptiva e desperta nesses a partilha sensível daquilo que é comunicado. A descrição verbal de uma paisagem longínqua, por exemplo, expõe a um ouvinte que a desconhece uma experiência que ele mesmo poderia ter se diante dela estivesse. O caráter eminentemente partilhável da visão de tal paisagem é confirmado por meio do diálogo. Em si mesma, como evento silencioso, a vivência sensível da paisagem se confundiria com a perspectiva individual, aparentemente intransferível, que cada sujeito apreende do mundo. Porém, por meio da linguagem, tal como afirma Merleau-Ponty, "a totalidade privada fraterniza com a totalidade social" (PM, 202), quer dizer, a perspectiva subjetiva em que cada sujeito está confinado se revela não como ponto de vista inacessível, mas como um foco de experiências eminentemente partilháveis. Destarte, o exercício da linguagem permite que a universalidade tácita do sentir (o fato de que todos os sujeitos de mesma constituição psicofisiológica experimentam perspectivas intercambiáveis do mesmo mundo) seja reconhecida como verdadeiramente universal (Cf. PM, 197, 202) . $^{39}$.

\footnotetext{
${ }^{39} \mathrm{Em}$ nossa leitura, a universalidade do sentir pode ser reconhecida explicitamente apesar das diferenças culturais e lingüísticas que favorecem determinadas maneiras de apreender os dados fenomênicos. Afirmamos, na subseção "A percepção enformada culturalmente" que, dada a enformação cultural da atividade perceptiva, os conteúdos sensíveis não são de imediato diretamente partilháveis. Porém, supomos que por meio do aprendizado de uma língua e de uma cultura diferente, um sujeito pode confirmar em sua própria experiência uma maneira de discriminar certos dados no campo fenomenal a qual não era possuída de início por ele. Assim, embora não haja um só modo de apreender os dados perceptivos, os diferentes parâmetros culturais de discriminação de dados fenomênicos são potencialidades que todo sujeito perceptivo, como portador de uma função universal, a saber, o sentir, em princípio poderia atualizar.
} 
Deve-se notar que a linguagem comunica a experiência por palavras gerais, que não foram talhadas para exprimir essa ou aquela vivência particular. Por exemplo, as cores e as formas figuradas no campo fenomenal são apresentadas por vocábulos públicos (verde, cônico, etc.), que, em princípio, não se referem a nenhuma experiência em particular. A linguagem explicita o caráter geral da vivência sensível, e ao fazê-lo, parece que as vivências perdem qualquer conteúdo singular e se explicitam apenas em seus aspectos abstratos. No entanto, para Merleau-Ponty, essa aparente limitação pode ser compensada pelo fenômeno da expressividade. Segundo o filósofo, "a linguagem pode ser tratada como uma gesticulação de tal modo variada, precisa, sistemática e capaz de recortes tão numerosos, que a estrutura interna do enunciado só pode finalmente convir à situação mental à qual ela responde e dela se torna o signo sem equívoco" (PII, 43). Não se trata de defender que haja, de início, vocábulos que diretamente traduzem a particularidade de cada experiência. Mas, indiretamente, por meio de torções expressivas impostas às palavras, ao menos existe a possibilidade de que o caráter único das experiências silenciosas seja comunicado ${ }^{40}$.

Essa capacidade de fixação e desvelamento indireto da experiência silenciosa será um dos principais recursos pelos quais Merleau-Ponty elaborará a sua ontologia final. Como veremos em nosso sexto capítulo, a investigação do ser bruto pretendida por $O$ Visível $e$ o Invisível não se realiza como uma designação simples dos componentes da realidade, como se se pudesse enumerar diretamente as propriedades do ser. Conforme vimos, dois sistemas diacríticos impedem o acesso direto ao ser: primeiramente, a percepção já ordena os dados como uma série de oposições, as quais podem ser motivadas por fatores culturais particulares. Em seguida, a linguagem fixa a experiência perceptiva de maneira indireta, servindo-se de um sistema de oposições de termos arbitrários em relação aos conteúdos percebidos. Ante a impossibilidade de um acesso direto ao ser, Merleau-Ponty, em sua investigação ontológica madura, tenta aplicar o potencial indireto da linguagem para explicitar a camada ontológica da qual o próprio sujeito surgiria. Dessa maneira, as longas reflexões sobre o tema da linguagem não só ampliam o escopo das análises fenomenológicas iniciais, mas também instituem a orientação metodológica pela qual a investigação ontológica futura deve se cumprir:

\footnotetext{
40 Para Merleau-Ponty, na literatura essa expressão extremamente refinada da experiência ocorre regularmente. Afinal, para ele, o escritor é justamente alguém que tenta "colocar em circulação não apenas os aspectos estatísticos e comuns do mundo, mas até a maneira pela qual [o mundo] toca um indivíduo e se introduz em sua experiência" (RC, 39).
} 
expressão indireta, por meio de capacidades expressivas lingüísticas, do ser silencioso que funda tal expressividade.

Mas não se deve pensar que os dados sobre os quais a ontologia, de uma maneira indireta, será formulada, provenham somente da percepção. É verdade que neste capítulo acentuamos o problema da articulação entre vida perceptiva e atividade lingüística. Mas a solução oferecida por Merleau-Ponty (reconstrução expressiva da experiência), a qual fornece a diretiva principal do uso da linguagem na empreitada ontológica, não se aplica somente aos dados obtidos pelas descrições da percepção ingênua. No geral, com as reflexões sobre a linguagem do início dos anos cinqüenta, Merleau-Ponty reconhece que não há via de acesso imediato ao ser e que a percepção, assim como a linguagem (e suas manifestações particulares seja na ciência seja nas artes), se relaciona com o ser indiretamente. Assim, conforme veremos nos capítulos a seguir, uma das principais marcas da ontologia madura de Merleau-Ponty será não condicionar a caracterização ontológica do mundo ao comentário dos dados advindos da percepção ingênua, tal como parecia ocorrer na Fenomenologia da Percepção. Ao assumir o caráter indireto da expressão (seja perceptiva ou lingüística), Merleau-Ponty deixa de favorecer os conteúdos percebidos como parâmetro pelo qual se pode delimitar diretamente a amplitude do ser, e concebe um novo tipo de abordagem ao problema ontológico. Neste segundo capítulo, apenas tentamos mostrar como a orientação geral para essa nova abordagem se forma na obra de Merleau-Ponty. Mas cumpre ainda expor como tal abordagem será efetivamente utilizada. 


\section{Capítulo III - Rumo ao ser primordial}

\section{Sinopse}

Neste capítulo, analisamos trechos dos cursos A Instituição, A Passividade $e$ A Natureza em que Merleau-Ponty esboça uma concepção do ser que não supõe a atividade subjetiva para sustentar suas características (ser primordial). De A Instituição, acompanhamos a descrição de estruturas significativas que não se ordenam como objetos intencionais. De A Passividade, acompanhamos como a investigação dos estratos passivos da subjetividade sugere a existência de camadas mundanas que escapam à apreensão ativa do sujeito. Finalmente, dos cursos de A Natureza, acompanhamos a descrição do ser natural como conjunto de estruturas que autonomamente se ordenam como sensíveis, embora não se reduzam aquilo que é perceptivel.

\section{Introdução}

No capítulo anterior, expusemos um dos principais tópicos pelos quais MerleauPonty realiza a ampliação do escopo temático de sua análise fenomenológica nos anos cinqüenta, a saber, aquele da linguagem. Essa ampliação visava corrigir alguns problemas localizados pelo próprio Merleau-Ponty na Fenomenologia da Percepção (Cf. IP, 174-178). Além disso, o resultado de tal ampliação oferece um direcionamento metodológico para a investigação ontológica anunciada. Por sua vez, neste terceiro capítulo, acompanharemos como, no decorrer de alguns de seus cursos ministrados nos anos cinqüenta (A Instituição, A Passividade e A Natureza), Merleau-Ponty avança no desenvolvimento de tal investigação ontológica, de maneira a apontar soluções para alguns dos impasses da Fenomenologia da Percepção. Interessa-nos principalmente explicitar os esforços de Merleau-Ponty para elaborar uma noção de ser que escape das acusações de idealismo subjetivista, recebidas por ele em relação ao seu livro de 1945 , conforme vimos em nosso primeiro capítulo.

\section{A Instituição}

No curso A Instituição, ministrado em 1954-1955 no Collège de France, Merleau-Ponty pretende apreender em diferentes âmbitos um mesmo padrão de articulação significativa de fatos. Trata-se de explicitar como se elabora um sentido por meio de acúmulo e reorganização de experiências sedimentadas. Esse tipo de sentido se 
manifestaria tanto na vida animal ou na puberdade humana quanto no avanço do saber teórico. O conceito de instituição será apresentado como chave para compreender a ordenação dos fenômenos dessas diferentes áreas.

No início de seu curso, Merleau-Ponty rejeita a análise intelectualista da subjetividade (a qual antepõe a toda experiência vivida uma apreensão conceitual [Cf. IP, 33]) em favor da descrição da consciência como primordialmente inserida no sensível. Conforme tal descrição, as capacidades conceituais subjetivas se ordenam sobre os processos anônimos da vida sensível, os quais impõem restrições gerais para o posterior estabelecimento da subjetividade ${ }^{1}$. Assim, ao defender que as capacidades conceituais subjetivas (de caráter originário, segundo o intelectualismo) na verdade derivam de um processo instituinte anterior, Merleau-Ponty minimiza a força da doutrina intelectualista e abre caminho para sua própria posição, segundo a qual os processos de instituição do sentido (e não mais de constituição ativa) são verdadeiramente primários em várias áreas, inclusive naquela que se refere à formação da subjetividade.

Em seguida, Merleau-Ponty expõe diversos âmbitos em que a instituição (entendida como processo de ordenação de fatos anterior à apreensão conceitual) ocorre. Segundo o filósofo, a instituição já se faz notar no comportamento animal. Em muitos animais, a gestualidade não é totalmente pré-determinada por estruturas inatas, mas moldada conforme o contato com as situações vividas. A manifestação de alguns instintos, por exemplo, não é estritamente ligada a certos objetos ou situações estabelecidos inatamente, e pode, por conseguinte, ser destravada ante estímulos diferentes daqueles a que normalmente os animais deveriam responder. Existe, então, a possibilidade de que certas condutas sejam deflagradas não por determinação biológica, mas pela simples busca de prazer, por exemplo. Nesses casos, ocorre a instituição de um simbolismo primitivo entre os animais: uma estrutura originária (os sistemas orgânicos) permite a sedimentação de diferentes padrões pelos quais eventos ou situações mundanas são assimilados (Cf. IP, 53).

No que concerne aos seres humanos, a instituição é mais complexa que a animal, uma vez que não há só o desvio de algumas funções para novos usos, mas também a reintegração das estruturas existenciais passadas em configurações mais recentes (Cf.

\footnotetext{
${ }^{1}$ Merleau-Ponty já sustentava essa tese na Fenomenologia da Percepção. Segundo tal livro, nós devemos "nos alimentar e respirar antes de perceber e de ter acesso à vida de relação, ser para cores e para luzes pela visão, para os sons pela audição, para o corpo de outrem pela sexualidade, antes de ter acesso à vida de relações humanas" (PhP, 186).
} 
IP, 54). Um dos exemplos de tal complexidade provém da análise da puberdade. Nessa fase do desenvolvimento humano, ocorre a reativação das fantasias sexuais infantis; porém, essa reativação não acontece apenas no nível da imaginação, pois agora o corpo está hormonalmente maduro para vivenciar o que fora antecipado como fantasia. Assim, a instituição da sexualidade humana não se reduz a um amadurecimento linear de funções biológicas, mas implica a reintegração em um nível mais amplo de vivências outrora antecipadas pela imaginação (Cf. IP, 56).

Segundo Merleau-Ponty, a instituição também torna compreensível a ordenação do sentido no nível das relações humanas. O filósofo usa como exemplo a história da pintura: cada pintor, ao definir seu estilo, retoma ao menos algumas obras historicamente relevantes. Há, assim, uma assimilação do passado artístico, o qual serve de base para que novas soluções estéticas sejam buscadas. Por sua vez, as novas obras produzidas podem se sedimentar e servir como ponto de partida para o trabalho de outros pintores futuros (Cf. IP, 78-9). Essa lógica de sedimentação e retomada não estaria limitada às atividades artísticas, mas se reproduziria no âmbito do saber exato. Para Merleau-Ponty, a formulação de uma verdade matemática, por exemplo, decorre de um processo de generalização e integração dos saberes anteriores: um conhecimento matemático é adquirido quando novas fórmulas, além de exprimirem novas relações, subsumem parte ou mesmo a totalidade do conhecimento passado sob um novo modelo (IP, 95).

No último trecho de seu curso, Merleau-Ponty almeja mostrar que os processos instituintes também se encontram na história pública. Por exemplo, alguns povos se questionam pelo problema da sociedade verdadeira e, por conseqüência, tentam retomar sua história sedimentada a fim de extraírem dela alguma direção a seguir. Quanto a esse tópico da história pública, vale mencionar que Merleau-Ponty não pretende transformar a reflexão consciente sobre a história em critério de superioridade. Há certamente sociedades que não demonstram a preocupação de "se instituírem", no sentido de fomentar um determinado arranjo social em contraste com seu passado. Isso não significa que tais sociedades são inferiores ou primitivas. A comparação entre sociedades, se possível, deveria levar em conta diferentes parâmetros e não só a capacidade de auto-reflexão ou autotransformação ${ }^{2}$. Reconhecer a instituição em certas

\footnotetext{
${ }^{2}$ Merleau-Ponty assevera quanto às sociedades em que não se encontra a instituição do seu futuro sobre a retomada do passado: "o que não quer dizer que sob certas relações elas não sejam mais belas" (IP, 122).
} 
sociedades não implica, assim, atribuir a elas valor em detrimento de outros agrupamentos humanos.

Após expor os diversos âmbitos em que Merleau-Ponty encontra processos instituintes, cumpre-nos questionar pelo sentido filosófico da instituição. Com esse conceito, forja-se uma rubrica geral para o processo de estabelecimento de sentido por reordenação de estruturas sedimentadas. Esse processo não é coordenado ativamente pela consciência humana, já que ocorre em níveis que escapam a esse poder de ação direto, tais como a instituição do simbolismo primitivo entre os animais ou a instituição da história do conhecimento científico (um processo cuja duração excede em muito aquela vivenciada por uma consciência subjetiva). Deve-se acentuar o fato de que a instituição supõe uma espessura temporal própria, já que a retomada de configurações passadas e a instauração de linhas de força pelas quais os eventos futuros se ordenam não se reduzem ao desdobramento da temporalidade imanente à subjetividade, pois, como acabamos de ver, tais processos instituintes excedem aquilo que é ordenado pela consciência subjetiva (CF. IP, 102). Dessa maneira, a instituição não pode ser definida como um objeto intencional, o qual se manifestaria exatamente conforme os poderes cognitivos ou perceptivos do sujeito. A instituição não é correlata das visadas subjetivas, seus processos não são transparentes para a subjetividade, mas formam como que um horizonte sobre o qual a atividade consciente se exerce.

O conceito de instituição é um dos primeiros marcos pelos quais Merleau-Ponty tenta sistematizar o tema dos padrões de significação que não supõem uma correlação estrita com a subjetividade humana. O aprofundamento da reflexão em torno desse tema marcará os avanços da sua ontologia final em relação às posições da Fenomenologia da Percepção expostas por nós no primeiro capítulo. Tal avanço se faz notar de maneira ainda mais notória nos cursos A Passividade e A Natureza.

Somente acentuemos, antes de analisar tais cursos, que ao ser reconhecida em diversos âmbitos da existência, a instituição corrige a análise empobrecida da Fenomenologia da Percepção, por demais limitada à relação muda entre o sentir e a coisa material ${ }^{3}$. Assim, a investigação fenomenológica se amplia e inclui certas estruturas significativas atuantes também no mundo cultural, sem com isso abandonar as

\footnotetext{
${ }^{3}$ No curso A Passividade, Merleau-Ponty explicita sua intenção de ampliar o escopo da investigação fenomenológica: é necessário descrever "na ordem do percebido, não somente Dingwahrnehmung [percepção de coisa], mas Verhalten [comportamento] do qual ela é um caso particular; não somente um campo sensorial, mas campos ideológico, imaginário, mítico, práxico, simbólico - ambiente histórico e percepção como leitura desse ambiente" (IP, 175).
} 
bases sensíveis da experiência, ambos os tópicos recobertos pelo vasto escopo da instituição.

\section{A Passividade}

No curso A Passividade, também ministrado em 1954-1955, Merleau-Ponty busca explicitar os níveis em que a experiência humana não pode ser definida como um fluxo de vivências ativamente ordenadas. Com a noção de passividade, o filósofo tenta apreender as dimensões da existência anteriores ou independentes das decisões voluntárias. Daí que nesse curso, se estude o sono, os sonhos, o inconsciente e a memória. Trata-se de mostrar por meio desses eventos ou estados que a subjetividade humana comporta diversas camadas constitutivas, e que a atividade consciente é apenas parte de um campo existencial mais vasto.

A investigação de camadas passivas no interior da subjetividade instaura a questão de saber como ocorre a integração entre tais camadas e as capacidades ativas do sujeito. Merleau-Ponty analisa e rejeita, no início do seu curso, a solução a esse problema oferecida por Lachièze-Rey (Cf. IP, 157-8). Segundo esse autor, o sujeito humano transforma as situações em que é passivamente afetado ao assimilá-las de modo voluntário: é verdade que o sujeito se encontra inserido em um contexto sócio-histórico não constituído pelos poderes da consciência; no entanto, por meio da sua decisão, o sujeito apreende e se insere ativamente em tal contexto. Para Merleau-Ponty, a posição de Lachièze-Rey contém apenas uma solução aparente ao problema da integração entre passividade e atividade (Cf. IP, 157), pois somente constata haver, por um lado, a inserção no mundo prévia às decisões subjetivas (passividade), e, por outro, as decisões que se voltam sobre tal inserção (atividade). Ora, essa constatação de duas esferas autônomas na subjetividade apenas repõe o problema da integração de ambas, mas não o soluciona.

Cumpre notar que a posição de Lachièze-Rey muito se assemelha àquela do próprio Merleau-Ponty na Fenomenologia da Percepção. Segundo esse livro, inicialmente o sujeito se encontra engajado passivamente em contextos não constituídos por ele (Cf. $\mathrm{PhP}, 500)$. Porém, o sujeito pode exercer sua liberdade e assumir resolutamente essas condições casuais pelas quais existia até então (Cf. PhP, 520). Desse modo, Merleau-Ponty parece admitir, no livro de 1945, a coexistência de dois princípios distintos na subjetividade (o passivo e o ativo), sem se questionar adequadamente pela possibilidade da sua integração. Como a atividade surge em um 
sujeito originariamente passivo? Será tal atividade uma transformação da passividade ou um princípio independente dessa última? Se se trata de uma transformação, como é possível que a passividade se metamorfoseie em seu contrário? E se se trata de um princípio independente, qual sua fonte e qual seu estatuto ontológico? $\mathrm{Na}$ Fenomenologia da Percepção essas questões não são claramente respondidas. Desse modo, julgamos que a crítica a Lachièze-Rey no curso A Passividade vale tanto como auto-crítica implícita à posição insuficiente da Fenomenologia da Percepção no que concerne a esse tema quanto como estímulo para que se formule uma nova concepção de subjetividade.

\section{Exemplos de passividade}

Vamos expor, em suas linhas gerais, os temas que Merleau-Ponty subsume ao conceito de passividade em seu curso de 1954-1955. O primeiro deles é aquele do sono e do sonho. Quanto a esse tema, o filósofo desenvolve sua análise em contraposição àquela de Sartre. Segundo Merleau-Ponty, para Sartre dormir "é como estar na vigília, é ter consciência de alguma coisa, com simples diferença na estruturação hilética: adequação em um caso, inadequação em outro" (IP, 195). Sartre conceberia a entrada no sono e/ou sonho (ele não teria distinguido adequadamente entre esses dois estados) como desligamento do mundo e livre exercício da consciência imageante, cujas significações produzidas nesse estado não precisariam se adequar à matéria sensível (tal como ocorre na percepção). Para Merleau-Ponty, essa concepção acentua demasiadamente o papel ativo da consciência como produtora dos sonhos, e, desse modo, ignora a especificidade do sono, do qual a atividade onírica é derivada.

O sono supõe, assim nos conta Merleau-Ponty, o afrouxamento dos sistemas discriminativos da percepção, os quais nos oferecem, na vigília, a paisagem estável do mundo. Dormir não implica um desligamento total em relação ao meio ambiente (do contrário não haveria como explicar o retorno à vigília por meio de ruídos, toques, ou seja, por meio de estímulos mundanos que despertam o corpo), mas supõe certamente uma redução significativa, ao menos temporariamente, das capacidades perceptivomotoras. É sobre essa regressão dos poderes subjetivos imposta pelo sono que os sonhos, com sua lógica bastante peculiar, ocorrem. "O sonho não é o sono, é o compromisso do sono com a vigília" (IP, 197), afirma Merleau-Ponty. No sono, a situação geral da vida subjetiva não é aniquilada; porém, como os sistemas diacríticos do corpo estão entorpecidos, o sujeito se relaciona com tal situação não por uma tomada 
de posição efetiva, mas pelo sonho, ou seja, por uma ordenação frouxa do seu drama individual num campo de presença montado espontaneamente com fragmentos da vigília e da memória. Assim, o sonho não decorre da atividade de uma consciência imageante, mas da passividade do corpo. Daí que os sonhos se ordenem por uma linguagem por vezes confusa (fruto do adormecimento dos sistemas discriminativos da percepção), a qual não é ativamente criada pelo sujeito, mas a qual justamente exprime a passividade do estado corporal do sono.

Merleau-Ponty estende para o tema do inconsciente seu esforço de conceber o simbolismo do sonho como expressão de um nível existencial anterior à atividade subjetiva. Segundo o filósofo, com a noção de inconsciente a tradição psicanalítica busca compreender aquelas situações que são vividas pelo sujeito sem um saber explícito, embora elas sejam passíveis de reconhecimento posterior. Uma viúva solitária, por exemplo, arruma distraidamente a mesa do café com duas xícaras. Em seguida, dá-se conta de seu engano e nele reconhece uma tentativa de superar os sofrimentos da solidão. Nesse caso, a arrumação da mesa com duas xícaras teria ocorrido de modo inconsciente: a viúva não sabia explicitamente que assim agia. No entanto, a intenção de superar a solidão não era totalmente ignorada pela mulher, que em seguida a reconhece como uma preocupação incômoda e constante. Esse exemplo simples ilustra a ambigüidade entre um não saber e uma não ignorância, ambigüidade que justamente se tenta apreender pela noção de inconsciente.

Merleau-Ponty rejeita conceber o inconsciente como uma segunda consciência no interior da subjetividade. Segundo essa interpretação rejeitada, haveria um saber explícito das intenções do sujeito (em nosso exemplo, a insatisfação com a viuvez), o qual, diante de mecanismos de repressão, só poderia se manifestar seja numa linguagem cifrada seja em lapsos comportamentais (arrumar a mesa com duas xícaras, no exemplo acima). Deve-se supor, segundo tal interpretação, um sujeito do inconsciente, que, de um ponto de vista privilegiado, sabe antecipada e adequadamente a verdade das experiências do sujeito consciente. Por sua vez, Merleau-Ponty propõe uma interpretação alternativa, que dispensa a suposição de dois sujeitos na mesma pessoa. Para ele, as ambigüidades do inconsciente se tornam compreensíveis se remetidas à percepção. A atividade perceptiva não apenas apreende conteúdos positivos, mas também envolve a não percepção de diversos elementos que compõem o horizonte perceptivo (partes dos objetos e da paisagem que não são vistas, vários ruídos de fundo que não são registrados, etc.). Os dados sensíveis compõem uma situação complexa, da 
qual o sujeito perceptivo não se dá conta completamente, embora, se necessário, possa estender sua atenção para certas configurações do campo que compunham a paisagem geral percebida, porém não de maneira explícita. A abertura perceptiva para o mundo seria, assim, o modo pelo qual o inconsciente originariamente se ordenaria (Cf. IP, 212).

Segundo Merleau-Ponty, a abertura perceptiva institui matrizes simbólicas por meio das quais as situações vividas são apreendidas. Certas situações, por exemplo, são imediatamente percebidas como tensas ou agradáveis sem que se tenha explicitamente avaliado os elementos que as compõem. Ocorre que as experiências particulares são assimiladas a certos padrões pelos quais a percepção discerne seus dados. Em nosso exemplo da viúva, os gestos de arrumação da mesa naturalmente envolviam ressonâncias do convívio com o marido, e espontaneamente reproduziram uma situação habitual que, no entanto, não podia mais se repetir. Não é preciso supor um sujeito oculto que ativamente tenha orquestrado o lapso comportamental; basta reconhecer a eficácia passiva de um modo geral de perceber e se inserir no mundo, o qual por vezes se sobrepõe àquilo que a especificidade da situação em questão exigira, tal como a arrumação de uma mesa com duas xícaras por uma viúva exemplifica. A situação particular requeria não mais de uma xícara. Porém, o caráter típico ou familiar que compunha tal situação, e que estava associado a duas xícaras, se impõe sobre a vivência atual.

O exemplo da viúva nos ajuda a entender de que maneira Merleau-Ponty pretende que sua noção de inconsciente se aplique ao caso das vivências traumáticas, as quais, segundo certas interpretações, seriam recalcadas mas mesmo assim coordenariam algumas atitudes dos indivíduos. Segundo o filósofo, não é preciso supor um reservatório de representações inacessíveis à consciência senão de maneira distorcida ou figurativa (mas plenamente explícitas para o suposto sujeito do inconsciente). $\mathrm{Na}$ verdade, os eventos traumatizantes instituíram matrizes simbólicas e sugeririam condutas estereotipadas ante as situações particulares que remetem a tais matrizes. Não haveria, desse ponto de vista, uma causalidade oculta, provinda de representações reprimidas, a determinar certas atitudes subjetivas, mas sim marcos gerais, atuantes na percepção, que delimitam a apreensão dos eventos mundanos ${ }^{4}$.

\footnotetext{
${ }^{4}$ Em A Natureza Merleau-Ponty relativiza o papel do inconsciente do recalque, o qual seria "uma formação secundária, contemporânea da formação de um sistema percepção-consciência" (N, 381). Por sua vez, o "inconsciente primordial seria o deixar-ser, o ser inicial, a indivisão do sentir" (Ibid.). O
} 
A reflexão de Merleau-Ponty sobre o inconsciente se desenvolve em um questionamento acerca da memória, ou seja, da conservação do passado na vida atual. É no presente que o reconhecimento de algo como passado ocorre; no entanto, para o filósofo, não é por meio da consciência presente que o passado é constituído enquanto tal. Se assim fosse, o conteúdo ao qual se atribuiria a significação "passado" seria na verdade um conteúdo presente, e, desse modo, não haveria acesso verdadeiro ao passado (Cf. IP, 269). Para Merleau-Ponty, a memória não se limita a recriar ativamente conteúdos sensíveis que deixaram de existir. Há uma presença do passado que passivamente se impõe ao sujeito. Essa presença ocorre por meio do corpo: "lembrar-se de qualquer coisa é lembrar-se do modo como se tinha acesso a esse qualquer coisa (...), é então lembrar-se de uma certa maneira de ser corpo" (IP, 269). O problema da memória se inverte: não é mais a conservação da imagem e a capacidade mental de recriá-la que faz com que haja passado para nós, mas é porque o corpo passivamente adquire uma espessura temporal e assim nos liga diretamente com o passado que as lembranças podem ser conservadas e ressurgir para a consciência presente.

Ao atribuir uma espessura temporal ao corpo, Merleau-Ponty se afasta da doutrina da temporalidade tal como exposta na Fenomenologia da Percepção. Segundo esse livro, o tempo é um fluxo contínuo de passagem, que se marca como instantes diferenciados. Esse fluxo se confunde com a própria vida da consciência subjetiva, e é apenas por meio dela que, de um modo derivado, pode-se atribuir um caráter temporal aos eventos do mundo (Cf. PhP, 471). Já em A Passividade, baseado em algumas descrições de Proust, Merleau-Ponty afirma que o tempo "se lê no esquema corporal" (IP, 255). Dessa maneira, não são estruturas subjetivas aquelas pelas quais ocorre a temporalidade, mas sim estrutura anônimas, oriundas do corpo, as quais passivamente ordenam o fluir temporal. “Uma grande fadiga e seu ‘deslocamento orgânico’ pode nos

inconsciente do recalque seria somente uma modulação particular (referente a eventos traumáticos) do modo geral pelo qual as matrizes simbólicas funcionam normalmente na percepção. Além disso, MerleauPonty questiona a concepção do conteúdo do inconsciente do recalque como repositório de representações traumáticas vividas na primeira infância e então conservadas. $O$ filósofo sugere que essa concepção projeta sobre a vida infantil o modo adulto de compreender e assimilar as vivências. Afinal, a noção de representações cujo sentido (incompatível com a consciência) deve ser reprimido supõe justamente uma consciência de si já plenamente estabelecida, em oposição à qual determinado conteúdo deve permanecer inconsciente. Ora, por sua vez, o eu infantil "não se fala nem se pensa" (N, 352), e dificilmente classificaria tais vivências com o mesmo peso pelo qual alguns psicólogos as tacham de traumáticas. Em suma, a consciência infantil não disporia dos mecanismos de defesa pelos quais o inconsciente do recalque seria constituído. Aquilo que muito posteriormente os adultos sob tratamento psicanalítico reconhecem como recalques infantis seriam então projeções tardias das supostas causas dos conflitos atuais na infância, mas não explicitações de um conteúdo que desde o início da vida porta o mesmo caráter traumático. 
recolocar no nível das fadigas da infância e nos dá a infância” (IP, 276), exemplifica Merleau-Ponty.

Vale notar que na Fenomenologia da Percepção Merleau-Ponty admite rapidamente a existência de um tempo generalizado anterior à temporalidade subjetiva. "Esse tempo é aquele de nossas funções corporais, que são cíclicas como ele, é também aquele da natureza com a qual nós coexistimos" ( $\mathrm{PhP}, 517)$. No entanto, naquele livro, essa tese de um tempo generalizado, partilhado pelo corpo e pela natureza, não é desenvolvida, já que vigora a concepção que identifica temporalidade e subjetividade. Por sua vez, no decorrer dos anos cinqüenta, Merleau-Ponty busca "dessubjetivar" o tempo, de modo a associá-lo primeiramente ao corpo e posteriormente ao próprio ser (como veremos em nossa análise dos cursos sobre a natureza, logo a seguir, e em nossa conclusão) $)^{5}$.

Uma vez retomados os estudos pelos quais Merleau-Ponty explicita a passividade, tentemos sintetizar o interesse filosófico de tal empreitada. Trata-se, sem dúvida, de explicitar estruturas existenciais que antecedem a e/ou são independentes da atividade subjetiva. Essas estruturas estabelecem um contato com o mundo diferente daquele obtido pela compreensão ativa das situações vividas. Nesse sentido, o reconhecimento de estruturas passivas da existência humana sugere uma renovação ontológica: essas estruturas nos abrem para o mundo não como um conjunto de objetos delimitados pelas capacidades cognitivas, mas como campo denso de eventos, que mobiliza a subjetividade de uma maneira que ela mesma não coordena totalmente. Assim, por exemplo, as matrizes simbólicas captadas pela percepção, longe de ser projeções da subjetividade, parecem exprimir uma articulação de sentido inerente ao mundo sensível. Por sua vez, a temporalidade, não mais concebida como expressão da subjetividade, parece se caracterizar como registro corporal de um fluxo de passagem que pertence à própria natureza. Desse modo, os sistemas passivos do corpo sugerem a investigação do mundo não como correlato dos poderes da subjetividade, mas como uma infra-estrutura sobre a qual a subjetividade se erige. É o estudo dessa infraestrutura que os três cursos de Merleau-Ponty sobre a natureza oferecem.

\footnotetext{
${ }^{5}$ Deve-se também notar que Merleau-Ponty já se refere na Fenomenologia da Percepção a excertos de Proust para defender o papel constitutivo do corpo na ordenação das memórias (Cf. PhP, 211). No entanto essa menção ocorre no capítulo "O corpo como expressão e a fala"; no capítulo referente à temporalidade, o corpo tem pouco ou nenhum papel na ordenação do fluir temporal.
} 


\section{A Natureza}

Merleau-Ponty ministra três cursos sobre a natureza (entre 1956 e 1960). No primeiro deles (1956-1957), avalia as principais concepções filosóficas sobre a natureza à luz de algumas teorias da física contemporânea. No segundo (1957-1958), apresenta reflexões sobre a animalidade e a vida em geral. Finalmente, no terceiro (1959-1960), esboça uma passagem do mundo animal ao mundo da cultura por meio de considerações acerca do corpo humano. Com tais cursos, o filósofo explora detalhadamente a infraestrutura ontológica da qual o ser humano se erige (vislumbrada no curso $A$ Passividade). Essa exploração implica significativas alterações em sua perspectiva teórica, tal como indica o seguinte excerto do resumo do primeiro curso sobre a natureza: "se nós não nos resignamos a dizer que um mundo de onde seriam retiradas as consciências não é nada, que uma Natureza sem testemunhos não teria sido e não seria, nos é necessário de algum modo reconhecer o ser primordial que não é ainda o ser sujeito nem o ser objeto, e que desconcerta a reflexão em todos os sentidos" (N, 357).

Nesse trecho, Merleau-Ponty se esforça por não mais limitar o ser do mundo àquilo que é passível de apreensão pela consciência humana. Vimos, em nosso primeiro capítulo, que na Fenomenologia da Percepção o ser é definido como aquilo que se manifesta sensivelmente (Cf. PhP, 455). Essa perspectiva ainda era defendida no curso A Passividade, segundo o qual "o homem jamais pode pensar uma natureza sem o homem" (IP, 172). É verdade que no curso de 1954-1955, Merleau-Ponty admite uma relativização da atividade perceptiva ${ }^{6}$. Mas essa relativização se refere apenas ao reconhecimento de que certos conteúdos percebidos decorrem de limitações da perspectiva subjetiva e não correspondem ao modo como a situação está de fato ordenada (por exemplo, a percepção de que o sol se move). No que tange à concepção de ser em geral, a percepção permanecia como principal critério ontológico ${ }^{7}$, no sentido em que o ser ainda era definido como ser perceptível. Por sua vez, nos cursos sobre a natureza, conforme o excerto citado acima expõe, Merleau-Ponty parece relativizar até mesmo esse último privilégio da consciência perceptiva, pois admite um ser primordial que existe independentemente de qualquer apreensão subjetiva. Dessa maneira, o filósofo recusa a tese de que o ser supõe um testemunho subjetivo tácito que o delimite

\footnotetext{
${ }^{6} \mathrm{Na}$ Fenomenologia da Percepção, Merleau-Ponty apresentava a percepção como "acesso à verdade" (PhP, XI), e, por conseguinte, defendia: “o levantar do sol e em geral o percebido é 'real"” (PhP, 396). Já em A Passividade, admite que "seria falso crer no sol móvel" (IP, 173) tal como manifestado pela percepção ingênua.

7 "Há, na ordem do ser e não do ente, uma verdade da percepção que permanece" (IP, 173).
} 
de antemão como ser percebido. Trata-se, sem dúvida, de uma recusa desconcertante para a reflexão de cunho fenomenológico, tal como desenvolvida nas obras anteriores de Merleau-Ponty. Lembremos, por exemplo, que no artigo "O metafísico no homem", de 1947, Merleau-Ponty reconhecia como fato metafísico fundamental que só existe o ser-para-mim e que fora da correlação com a subjetividade não havia sentido em prosseguir com uma investigação ontológica (Cf. SnS, 114). Por sua vez, nos anos cinqüenta, o filósofo parece abandonar tal concepção e reconhecer que a investigação ontológica deve buscar o ser anterior à correlação subjetiva, ou seja, deve deixar de focar o ser que dela resulta (ser-para-mim) e explicitar o ser que a funda e a torna possível (ser primordial) ${ }^{8}$. Vejamos em que medida os cursos sobre a natureza fornecem subsídios para essa tarefa.

\section{Uma abordagem histórica}

$\mathrm{Na}$ parte inicial de seu curso de 1956-1957, Merleau-Ponty apresenta uma história conceitual da idéia de natureza tal como exposta por diversos filósofos. Por meio dessa história, o filósofo pretende mostrar que a concepção da natureza como autoprodução de um sentido independente e anterior à atividade subjetiva por diversas vezes figurou como alternativa teórica às idéias tradicionais mecanicistas ou intelectualistas acerca do mundo natural. Porém, tal alternativa jamais foi desenvolvida adequadamente pelos filósofos em pauta, os quais oscilam entre ela e tais idéias tradicionais da natureza.

Descartes, por exemplo, define, por um lado, a natureza como um produto do poder divino, produto sem interioridade própria. A natureza teria sido criada como total positividade, como atualização plena de todas as suas possibilidades, de modo a não haver nenhuma finalidade a ser atingida. Por conseguinte, o mundo natural deve ser estudado como um mecanismo ordenado por um sistema eterno de leis (Cf. N, 26-33). Por outro lado, ao considerar o composto humano de alma e corpo, Descartes hesita em submetê-lo às mesmas regras mecanicistas que regeriam o restante da natureza material. Parece mesmo haver uma tentativa de conceder à extensão corporal atributos da substância espiritual, tal como a unidade interna de todas as suas funções. Assim como

\footnotetext{
${ }^{8}$ Não é verdade, assim, tal como julga Madison, que "a questão referente àquilo que o Ser poderia ser sem o homem ou antes dele não parece ter muito sentido para Merleau-Ponty" (Madison, G. B. The Phenomenology of Merleau-Ponty. A search for the limits of consciousness. Ed. supra, p.221). Talvez essa questão não fizesse muito sentido na época da Fenomenologia da Percepção, mas certamente é bastante significativa nas suas reflexões dos anos cinqüenta.
} 
no espírito a imaginação, a vontade e demais atos estão subsumidos ao autoreconhecimento do sujeito como base da vida psíquica, do mesmo modo no corpo, a motricidade, a percepção e demais funções não seriam sistemas mecânicos separados, mas sim expressões de uma unidade de princípio, aquela das intenções corporais (Cf. N, 38). No entanto, Descartes não avança em uma reflexão acerca da existência encarnada, cujas aparentes peculiaridades são remetidas às idéias confusas da vida cotidiana. Uma vez assumido o método que busca idéias claras e distintas, é a concepção mecanicista da natureza que vigora.

Também há oscilação na definição da natureza por Kant. Por um lado, o filósofo alemão concede poder constituinte às categorias do entendimento humano, de modo que a natureza se reduz aos objetos da experiência ordenados conforme os poderes da subjetividade humana. Por outro lado, essa concepção depende da existência de uma natureza prévia, a qual fornece os dados sensíveis sobre os quais a atividade constituinte subjetiva se exerce. Haveria assim uma natureza fáctica que sustentaria os poderes da subjetividade. No entanto, uma vez que a doutrina kantiana se limita a estudar os fenômenos tais como constituídos pelas categorias cognitivas, tal natureza fáctica não é devidamente explicitada (Cf. N, 40-47).

É possível encontrar também em Husserl uma dupla tendência na reflexão sobre a natureza. No início de Idéias II, Husserl apresenta a natureza como esfera das meras coisas (blosse Sachen), quer dizer, das coisas abstraídas de quaisquer significados subjetivos e consideradas apenas em sua materialidade. Essa concepção seria aquela da atitude teórica, na qual o conhecimento científico é produzido. Porém, ao lado dessa concepção, Husserl desenvolve a noção de natureza como um campo primordial que estaria na origem da noção de meras coisas materiais. Esse campo primordial seria ordenado não pelas categorias do entendimento, mas conforme as capacidades corporais. Somente após um longo processo de objetivação (que envolve um esforço conjunto de diversos sujeitos) surgiria a idéia de meras coisas materiais. Inicialmente, na experiência concreta, a natureza se apresentaria como um ser pré-objetivo que torna possível e sustenta os poderes subjetivos ${ }^{9}$. No entanto, Husserl intitula essas análises de

\footnotetext{
${ }^{9}$ Segundo Merleau-Ponty, Schelling foi o filósofo que começou a articular uma concepção de natureza anterior à sua apreensão intelectual. "O que Schelling quer dizer é que se redescobre a natureza em nossa experiência perceptiva antes da reflexão" (N, 63), defende o fenomenólogo. Schelling teria buscado, ao estudar a percepção, uma unidade primordial do sujeito com a natureza: "o que se chama de eu e o que se chama de ser vivo têm uma raiz comum no Ser pré-objetivo" (N, 64).
} 
preparatórias, feitas ainda sob a atitude natural, excluindo seus resultados do nível transcendental puro (Cf. N, 102-113).

\section{Ciência e natureza}

A história conceitual apresentada por Merleau-Ponty no início de seu curso sobre a natureza é bem mais complexa do que os tópicos apontados por nós na subseção passada. Interessou-nos somente expor as tensões encontradas por Merleau-Ponty na reflexão de alguns autores. Essas tensões são significativas, pois anunciam a concepção que o filósofo francês desenvolverá, a saber aquela de uma natureza fáctica, cuja produtividade (que os autores estudados apenas entreviram sem assumi-la explicitamente) é anterior ao uso ativo das capacidades subjetivas.

Merleau-Ponty busca apoio na ciência contemporânea para desenvolver tal concepção. As teorias físicas do início do século vinte não corroboram a concepção de natureza como um mecanismo perfeitamente comandado por leis eternas ou perfeitamente determinado por categorias do entendimento. A mecânica quântica, acredita o filósofo, ensina que, ao menos no nível subatômico, não há um conhecimento determinado pleno, pois nesse nível a probabilidade se manifesta como uma propriedade constituinte do ser (Cf. N, 125-132). Além disso, a ciência contemporânea sugere uma compreensão renovada do espaço e do tempo. Quanto ao primeiro, as métricas não euclidianas mostram que a geometria clássica não possui nenhum privilégio ontológico, quer dizer, não espelha o ser de um modo mais ou menos adequado que outras geometrias. Haveria um espaço polimorfo, que aceita diversas métricas sem privilegiar nenhuma em particular. Quanto ao tempo, a idéia de que há uma sucessão de instantes objetiva, válida para todo o universo (em relação à qual cada objeto exibiria uma única localização temporal) é rejeitada pela física relativista. Segundo essa última, o tempo não é um fenômeno indiferente aos acontecimentos que nele se desenrolam, nem aos pontos de vista subjetivos (Cf. N, 139-152).

Essa renovação das noções básicas da física (determinação, espaço e tempo) sugere uma idéia de natureza não mecanicista e não intelectualista. Merleau-Ponty se serve das reflexões de Whitehead para dar forma a essa nova idéia decorrente das teorias científicas contemporâneas. Segundo Whitehead, a natureza era concebida pela maior parte dos cientistas e filósofos modernos (por exemplo, por Laplace) como conjunto de objetos espaço-temporais existentes em instantes sucessivos que deixam de existir tão logo se tornem passados e que ainda não existem enquanto instantes futuros. 
Quer dizer que a natureza existiria como uma seqüência de instantes presentes que se sucedem como flashes descontínuos (Cf. N, 154). Whitehead rompe com essa definição. Para ele, a natureza não é um conjunto de objetos inertes submetidos a uma sucessão de instantes descontínuos. Haveria uma atividade interna de passagem no interior da natureza, ou seja, espontaneamente o mundo natural se ordenaria em conjuntos de relações que desdobram uma espacialidade e uma temporalidade próprias (Cf. N, 155$165)$.

Merleau-Ponty passa a considerar, com base nas reflexões de Whitehead, a existência de um tempo cósmico (Cf. N, 181), quer dizer, de um tempo inerente à natureza, o qual não é atribuído aos eventos pelas formas da sensibilidade humana, como julga o kantismo. Com essa idéia de um tempo inerente à natureza, MerleauPonty dá prosseguimento à reformulação, iniciada no curso A Passividade, de sua própria idéia de temporalidade. Ao analisar esse curso, vimos que o filósofo não mais identificava a temporalidade com a subjetividade, mas sim com os ciclos anônimos da história corporal. Essa tese permanece válida em A Natureza ${ }^{10}$; porém, nesse último texto, Merleau-Ponty esclarece que o tempo vivido pelo corpo é um processo que participa de um tempo inerente ao próprio mundo natural ${ }^{11}$. Haveria, assim, um desenrolar temporal mais amplo que aquele da temporalidade humana, um desenrolar da própria natureza, o qual tornaria possível a estruturação da temporalidade subjetiva. Essa assunção de um tempo natural fundante em relação ao tempo vivido implica um rompimento considerável com as posições da Fenomenologia da Percepção. Nessa obra, Merleau-Ponty afirma que "não há tempo natural, se se entende por isso um tempo das coisas sem subjetividade" (PhP, 516). A justificativa para tanto é que "se eu considero esse próprio mundo [objetivo] não há senão um só ser indivisível e que não muda" (PhP, 470). O tempo, desse ponto de vista, não seria um processo real, já que só existiria enquanto referido à subjetividade humana.

Em A Natureza, Merleau-Ponty critica explicitamente toda a tradição filosófica, que, de Santo Agostinho até Sartre, teria definido a natureza como um eterno presente e concebido o passado ou o futuro como dimensões ligadas à subjetividade humana (Cf. $\mathrm{N}, 161$ ). Essa longa tradição defenderia que cada instante do mundo ao deixar de ser

\footnotetext{
10 "A passagem do tempo está inscrita em nosso corpo" (N, 162).

${ }^{11}$ Deve-se notar, entretanto, que "falando assim não se fala de um tempo da natureza em si, mas de um tempo da natureza enquanto nós nela participamos" (N, 162). Não se trata, desse modo, de inserir o corpo no tempo medido objetivamente, mas de retraçar a gênese da temporalidade numa camada inerente ao próprio ser.
} 
presente não mais existiria senão como memória subjetiva. Por conseqüência, "se se pudesse abolir em pensamento todas as consciências, só restaria um brotamento de ser instantâneo, aniquilado assim que se manifestasse" (N, 357), já que toda duração temporal (o que supõe a passagem do presente em passado e a sua conservação ou sedimentação) só ocorreria em virtude da consciência. Ora, tal como vimos no parágrafo anterior, Merleau-Ponty bem poderia ter incluído nessa longa tradição filosófica a Fenomenologia da Percepção, pois nesse livro o mundo natural também é definido pela instantaneidade, e as dimensões temporais, associadas à subjetividade. Desse modo, as posições assumidas em A Natureza servem como autocrítica implícita e preparam o desenvolvimento de uma nova concepção de ser, a qual incluirá a temporalidade entre seus atributos.

Embora aponte para uma noção de ser cujos atributos são fundantes daquilo que a subjetividade pode experimentar (sem que necessariamente se reduzam àquilo que está em correlação com os poderes subjetivos), o primeiro curso de Merleau-Ponty sobre a natureza não despreza o ser percebido, ou seja, o ser tal como se manifesta em correlação com as capacidades perceptivas humanas. Ocorre que tal ser percebido recebe um papel mais modesto se comparado com aquele de definição geral do ser, exercido na Fenomenologia da Percepção. Retomemos o tema dos entes e eventos inobserváveis, exposto no primeiro capítulo, para esclarecer esse novo papel.

Conforme vimos, Merleau-Ponty, na Fenomenologia da Percepção, parecia definir os entes ou eventos inobserváveis como constructos culturais, pois não haveria verdadeiramente ser para além daquilo que se manifesta sensivelmente. Já em $A$ Natureza, o filósofo parece admitir que aquilo que existe não é somente o que se manifesta perceptivelmente, embora ainda sustente que o que quer que exista deve ser assimilado subjetivamente de maneira perceptiva. Essa mudança de perspectiva se torna patente quando Merleau-Ponty se refere aos temas estudados pela microfísica contemporânea. É em relação a eles que o ser percebido exercerá o seu novo papel, a saber, de parâmetro de inteligibilidade ou modelo analógico ${ }^{12}$. Para Merleau-Ponty, alguns problemas da física contemporânea, tais como a dualidade na interpretação de certas medidas (que podem ser analisadas como o registro do comportamento seja de partículas seja de ondas, conforme o observador interfira ou não no experimento), se aproximam do modo ambíguo como a percepção ordena seus dados. Na percepção, de

\footnotetext{
12 "O campo perceptivo nos oferece o primeiro modelo do Ser sobre o qual a ciência trabalha a fim de dar uma visão articulada do Ser” (N, 144).
} 
um campo global alguns dados são segregados e apreendidos como coisas. Quer dizer que as coisas percebidas não são núcleos duros de ser determinado, mas modulações do campo perceptivo conforme a atenção do sujeito. Ora, os microfenômenos estudados pela mecânica quântica parecem se organizar como o campo perceptivo, ou seja, tal qual um campo polimorfo que sustenta diversos eventos prováveis, os quais se individuam segundo a interferência subjetiva (Cf. N, 144). A física contemporânea não implicaria, por conseguinte, um desmentido da experiência ingênua, mas a confirmaria ao menos como inserção em um campo de eventos anterior aos sistemas clássicos de medida. A seguinte afirmação de Merleau-Ponty exprime essa perspectiva: "poder-se-ia dizer que a atitude do homem que percebe (...) simboliza com a atitude científica, nesse sentido que o homem de antes da ciência está tão pouco afundado no espaço euclidiano quanto o homem posterior à ciência" (N, 144). Importa aqui salientar que a atribuição do papel de modelo à percepção (quanto aos temas da microfísica) implica reconhecer algo modelado, que em si mesmo não é perceptível (embora partilhe de algumas características também encontradas no campo perceptivo, o que justamente permite a relação de modelagem conceitual). Assim, em A Natureza, Merleau-Ponty parece ter desenvolvido instrumentos teóricos para reconhecer a existência de X para além da concepção de X segundo os parâmetros perceptivos. Não é porque só se pode conceber $\mathrm{X}$ como percebido que $\mathrm{X}$ exista em si mesmo como necessariamente perceptível. Os eventos microfísicos, por exemplo, não são neles mesmos perceptíveis, mas não são, por isso, meros constructos culturais, tais quais ficções ou lendas. Trata-se, ao menos pretensamente, de eventos que compõem a natureza, embora só sejam compreendidos pelos seres humanos conforme as restrições perceptivas desses últimos.

Notemos, no entanto, que modelo ou guia para o entendimento de alguns temas da física contemporânea não será o papel final atribuído por Merleau-Ponty ao ser percebido. No segundo e terceiros cursos de A Natureza, de fato o ser percebido caracteriza uma camada ou estrato do ser do mundo, embora não mais a sua totalidade, conforme veremos no restante do capítulo.

\section{O ser sensível}

Em seu segundo curso sobre a natureza, Merleau-Ponty deixa de se centrar nos fenômenos físicos e se dedica a estudar alguns temas das ciências biológicas em geral. Entre os muitos tópicos discutidos, destaca-se aquele do mimetismo, cuja análise fornece elementos cruciais para a configuração de uma nova postura ontológica. No 
mimetismo, constata o filósofo, os organismos se confundem com o meio ambiente, o qual é anterior e indiferente a eles. Assim, por meio de certas estruturas orgânicas, alguns animais se assemelham a determinadas configurações geográficas. Há aqui uma dupla camada de eventos. Em primeiro lugar, o ambiente geográfico se manifesta de uma certa maneira, faz-se sensível em cores, formas e texturas determinadas. Em seguida, o modo como o corpo de alguns animais se desenvolve é tal que esses animais se manifestam, ou seja, fazem-se sensíveis, de maneira a confundir-se com o meio. Quer dizer que tanto o meio ambiente como os animais se organizam como sensibilidade potencial, sua forma é aquela para uma percepção possível, a qual, no caso do mimetismo, confunde as cores e formas dos seres vivos com aquelas da paisagem (Cf. N, 240-248).

Como conclusão da análise do mimetismo, Merleau-Ponty afirma: "o comportamento só pode se definir por uma relação perceptiva e que o Ser não pode ser definido fora do Ser percebido" (N, 247). Aqui vemos claramente que o ser percebido não se limita a mero padrão de inteligibilidade dos fenômenos físicos (como concluíra o primeiro curso sobre a natureza), mas constitui uma camada autônoma do ser. O mundo natural e os seres vivos incluem em seu existir uma referência a uma percepção possível, eles se ordenam como ser sensível. Deve-se notar que essa tese não significa um retorno à perspectiva teórica da Fenomenologia da Percepção, mas justamente uma importante alteração dessa última. Não se trata mais de partir de uma análise das capacidades perceptivas e então definir o ser como aquilo que aparece para o sujeito (tal qual aquela obra propunha). Trata-se, por sua vez, de reconhecer que o mundo, antes e independentemente de sua apreensão pelo sujeito perceptivo, organiza-se como sensibilidade iminente, de modo que as capacidades perceptivas podem então se exercer. Não é, assim, em decorrência da atividade perceptiva que se deve definir o ser como percebido (não é por se restringir o ser ao aparecer que se deve atribuir estatuto de realidade às manifestações sensíveis), mas sim porque em sua própria arquitetônica a natureza é sensível e se abre para visadas perceptivas.

\section{O corpo sensível}

Em seu terceiro curso sobre a natureza, Merleau-Ponty passa a considerar não apenas o corpo dos animais que se mimetizam como inseridos no ser sensível, mas também o próprio corpo humano, o qual porta em si um duplo aspecto. Por um lado, o corpo é medida de todas as coisas sensíveis (Cf. N, 273). Esse atributo não traz 
nenhuma novidade para os leitores de Merleau-Ponty, uma vez que a Fenomenologia da Percepção o acentuara vigorosamente. Segundo esse livro, a presença ou ausência das manifestações sensíveis decorre do modo como os sistemas corporais atribuem uma forma significativa aos estímulos (Cf. PhP, 89). Tais sistemas fornecem, assim, a medida daquilo que pode ser experimentado. Em A Natureza, Merleau-Ponty não rejeita essa capacidade transcendental do corpo, mas contrabalança esse atributo com um segundo aspecto, a saber, o fato de o corpo ser uma coisa sensível entre outras coisas sensíveis do mundo (Cf. N, 273).

Esse segundo aspecto do corpo implica novidades em relação às análises da Fenomenologia da Percepção. Nesse livro, Merleau-Ponty se esforça por caracterizar a absoluta singularidade do corpo próprio ante os objetos do mundo. O filósofo se serve do exemplo de duas mãos que se tocam para tanto. "Se eu posso apalpar com minha mão esquerda minha mão direita enquanto ela toca um objeto, a mão direita objeto não é a mão direita tocante" (PhP, 108). Há, assim, uma ambivalência inerente ao corpo: a mesma mão pode ser ativa (poder de exploração) e passiva (pacote inerte de ossos e carne). No entanto, essas características são mutuamente excludentes: em sua função exploratória o corpo não se reconhece como massa passiva e vice versa. Essa mútua exclusão implica que o corpo como veículo de intenções ativas, o corpo-sujeito que organiza o ambiente, jamais se confunde com um objeto. O corpo ativo é a medida pela qual as coisas as experiências se ordenam, e ele não se assemelha a nenhuma dessas $\operatorname{coisas}^{13}$.

Já em A Natureza, o corpo ativo não mais é considerado como excludente do corpo sensível (o qual seria semelhante, nesse aspecto, às coisas). O exemplo das mãos que se tocam é reutilizado por Merleau-Ponty, agora em favor de uma nova tese. "Minha mão é coisa sobretudo para a outra mão que a toca" $(\mathrm{N}, 285)$, constata o filósofo. Não se trata mais de reconhecer a absoluta irredutibilidade entre esses dois aspectos. Pelo contrário, Merleau-Ponty admite que "há um tipo de identidade do tocante e do tocado" (Ibid.), sustentada pelo fato de que a mão que toca poderia se tornar tocada e vice versa. O filósofo continua a defender que a identidade plena entre esses aspectos não se verifica: "no momento em que a mão tocada se torna tocante, ela cessa de ser tocada" (Ibid.). Mas sua conclusão geral não é em favor da singularidade do

\footnotetext{
13 "Enquanto vê ou toca o mundo, meu corpo não pode ser visto ou tocado [por si mesmo]. O que o impede de ser alguma vez um objeto, de ser alguma vez 'completamente constituído', é que ele é isso pelo que há objetos" (PhP, 108).
} 
corpo-sujeito em relação às coisas; na verdade, o exemplo das mãos que se tocam permite apreender "meu corpo em sua duplicidade, como coisa e veículo de minha relação com as coisas. São os dois 'lados' de uma experiência, conjugados e incompossíveis, complementares" (Ibid.). Assim, Merleau-Ponty acentua que o corposujeito não é completamente distinto das coisas, já que seu poder exploratório somente revela uma face da existência corporal, a qual também se define por seu caráter sensível, caráter partilhado pelas coisas do mundo.

É por meio dessa comunidade sensível entre corpo e mundo que se esclarece a gênese das capacidades perceptivas. O modo como Merleau-Ponty expõe esse tema parece sugerir, por vezes, que a reflexividade corporal (a referência do corpo a si próprio, de modo a assumir os papéis reversíveis de tocante e tocado) é a responsável por tornar possível a relação com o mundo: "o corpo como tocante-tocado, videntevisto, lugar de um tipo de reflexão e por aí capaz de se remeter a outra coisa que sua própria massa, de fechar seu circuito sobre o visível" (N, 270-1). Parece, assim, que a relação do corpo consigo é condição necessária e suficiente para qualquer reconhecimento dos dados exteriores, como se, ao se tocar, o corpo instaurasse uma capacidade que então poderia se aplicar ao mundo ${ }^{14}$. Essa é a interpretação defendida por Raphaël Gély em La Genèse du Sentir - Essai sur Merleau-Ponty ${ }^{15}$. Para esse autor, "a abertura do corpo ao mundo não tem nada de imediato" ${ }^{16 "}$. Como então ela surge? "É na medida em que o corpo humano é constituído de modo tal que um processo de gênese do sentir pode advir nele que esse mesmo corpo pode se estender a isso que o envolve" ${ }^{17}$. Segundo Gély, a experiência das mãos que se tocam é o modelo da criação de um espaço do sentir. "No seio de nossa experiência, o sentir se deixa descrever como um espaço de integração que é uma dupla explosão estabilizada das duas mãos uma para outra" ${ }^{\prime 18}$. Com essa metáfora da explosão, Gély expõe que o sentir surge como esforço para integrar os papéis incompossíveis das mãos (tocante/ tocada), de maneira a se estabelecer uma dimensão de interação do corpo com as coisas.

Essa interpretação parece, como vimos, abonada pelo próprio Merleau-Ponty. No entanto, defenderemos que ela não é completa. É verdade que a relação entre tocante/tocado garante ao corpo a instauração de um espaço ou dimensão na qual pode

\footnotetext{
14 "Como [o corpo] tem essa referência a outra coisa que si? Ele está aberto em circuito com o mundo porque ele está aberto: ele se vê, ele se toca" (N, 279).

${ }^{15}$ Bruxelles: Ousia, 2000.

${ }^{16}$ Ibid., p.79.

${ }^{17}$ Id., ibid.

${ }^{18}$ Ibid., p.70.
} 
sentir a si mesmo. Desse modo, o corpo obtém estados afetivos e toma consciência de si próprio. Mas como explicar a passagem da instauração do espaço do sentir intracorporal para a relação com o meio? Parece-nos que a instauração da reflexividade tocante/tocado não é condição suficiente para a entrada em vigor de tal relação. É preciso afirmar mais do que a reflexividade corporal para compreender o circuito com o mundo; trata-se de reconhecer que as coisas partilham do mesmo estofo sensível que o corpo e então se manifestam para seus poderes ativos (Cf. N, 280). É porque as coisas são sensíveis (assim como a mão tocada é sensível para a tocante) que o poder exploratório do corpo pode se aplicar sobre elas. Mas que as coisas sejam sensíveis e que o corpo carregue em si esse parentesco com elas não é ocasionado pela reflexividade entre tocante/tocado. Trata-se de características ontológicas oriundas da própria estrutura do mundo.

Explicitemos um pouco mais nossa tese: o corpo pode perceber outra coisa que si próprio não apenas porque há a instauração de uma interioridade senciente pela relação entre seus aspectos passivos e ativos, mas principalmente porque as coisas a que o corpo se dirige são sensíveis e se abrem aos poderes sencientes. Notemos que em relação à reflexividade corporal, a atividade exploratória do corpo não é senão a outra face de seu caráter sensível, passivo. A mão tocante, ativa, também é mão passiva, oferecida ao toque. Da mesma maneira, em relação à percepção do mundo, há também uma duplicidade passivo/ativo: as coisas devem ser sensíveis (como se a sensibilidade passiva do corpo se estendesse para o mundo), e então o poder exploratório se aplica sobre elas. Revela-se, por conseguinte, que o corpo não é só abertura aos fenômenos, mas também coisa sensível incrustada no mundo. Quer dizer que a percepção do mundo ocorre porque corpo e coisas partilham da mesma natureza, fazem parte da mesma carne sensível. O sentir não é, então, produzido apenas pela reflexividade corporal, pois também depende da organização do ser como camada sensível partilhada por coisas e corpo. Na verdade, mesmo a referência do corpo a si próprio pelas mãos que se tocam depende de certo arranjo do mundo sensível: a mão tocante descobre a localização da mão tocada por meio das referências espaciais do ambiente manifestadas no campo perceptivo ${ }^{19}$. Desse modo, "a relação com o mundo já está incluída na relação do corpo consigo mesmo" (N, 287), ou seja, para que o corpo se refira a si é necessária alguma

19 "Eu encontro minha mão a partir de seu lugar no mundo" (N, 346). 
orientação em relação ao ambiente sensível, e não que essa última se origine totalmente da reflexividade corporal.

\section{O ser negativo}

Tentamos mostrar que conforme os cursos sobre a natureza a experiência não apenas se torna possível por meio das capacidades perceptivas do corpo, tal como a Fenomenologia da Percepção acentuava, mas também, e principalmente, por meio da sensibilidade inerente às coisas e ao corpo. O seguinte trecho do segundo curso sobre a natureza exprime bem essa perspectiva:

admitir a existência de um órgão do sentido é admitir um milagre tão notável quanto admitir uma semelhança entre a borboleta e o meio, já que, no órgão do sentido, a matéria é disposta de tal modo que ela é sensível a um meio no qual o órgão não está. É assim que a fisiologia do aparelho visual é tal que a estrutura física desse aparelho permite atingir estruturas de perspectiva correspondendo a formas do ambiente $(\mathrm{N}$, 243).

Segundo esse excerto, a sensibilidade partilhada por órgãos corporais e por coisas mundanas sustenta a experiência. O corpo pode perceber algo porque sua estrutura sensível e aquela das coisas são comuns; não há assim nenhuma incompatibilidade entre o ser do mundo e aquele do corpo: ambos são arquitetônicas sensíveis que se ordenam como visíveis ou tocáveis, quer dizer, que se organizam para uma percepção possível (justamente aquela que o poder senciente do corpo exerce).

Já notamos que essas conclusões não estavam contidas na Fenomenologia da Percepção. Nesse livro, tal como vimos em nosso primeiro capítulo, a existência do mundo era delimitada conforme o repertório perceptivo do sujeito perceptivo, o qual portaria um projeto de todo ser possível (Cf. PhP, 411). Por sua vez, em A Natureza, Merleau-Ponty considera que é pela organização interna ao próprio ser, tal como o fenômeno do mimetismo exemplifica, que o mundo se faz sensível e se abre para a percepção. Nesse texto, o filósofo não parte dos poderes do corpo próprio para concluir acerca dos componentes ontológicos do mundo, mas se baseia nesses componentes para então justificar a atuação de tais poderes. No entanto, apesar das diferentes perspectivas teóricas assumidas na Fenomenologia da Percepção e em A Natureza, pode-se alegar que os resultados de ambas as obras convergem. Renaud Barbaras nos ajuda a explicitar esse ponto de vista. Segundo esse autor, as análises de A Natureza que reconhecem uma 
sensibilidade inerente ao ser implicariam que não há diferença entre realidade e manifestação sensível, pois a ordenação natural do mundo não é senão aquela que implica uma percepção possível:

A realidade não é nada mais que essa aparência, mas a aparência é uma realidade original e específica; ela existe 'em si' como aparência e assim não depende da consciência. A realidade, então, não é fenomenal porque se refere à consciência (essa ainda era a posição de $A$ Estrutura do Comportamento e da Fenomenologia da Percepção); antes, a realidade se refere à consciência porque ela é em si mesmo fenomenal ${ }^{20}$.

Barbaras resume, desse modo, sua interpretação das alterações no pensamento de Merleau-Ponty: de início, em A Estrutura do Comportamento e na Fenomenologia da Percepção, o filósofo partia da consciência perceptiva e concluía que o ser era idêntico a seu aparecer; já em A Natureza, Merleau-Ponty parte do próprio ser, mas também conclui que esse ser não se distingue do seu aparecer.

Defenderemos que essa interpretação não é correta, já que as análises de Merleau-Ponty acerca das estruturas do mundo (consideradas de maneira autônoma e não em sua correlação com a consciência perceptiva) não se limitam a concluir que o ser se abre a uma percepção possível e é completamente fenomenal ou apreensível pelas capacidades perceptivas. É verdade, Merleau-Ponty admite que é "a partir do sensível que podemos compreender o Ser" (N, 335), ou seja, que é por meio da camada ontológica organizada para uma percepção possível que temos acesso direto às estruturas do mundo. Mas isso não significa que o ser se reduza a essa camada que se fenomenaliza. Com efeito, Merleau-Ponty também sustenta a "inclusão do Ser visível em um Ser mais vasto" (N, 335), de modo a admitir que o ser perceptível não é a totalidade do ser. O ser do mundo se compõe, assim, não só de eventos ou coisas que se fenomenalizam; há também estruturas invisíveis, que não se doam à percepção humana senão como ausência e que, mesmo assim, participam da ordenação dos eventos mundanos. Alguns estudos contemporâneos de biologia, retomados pelo filósofo, exemplificam essa negatividade operante no interior do ser.

Em seu segundo curso sobre a natureza, Merleau-Ponty se dedica longamente a expor alguns estudos de embriologia conduzidos por Coghill $^{21}$ e por Gesell ${ }^{22}$, os quais

\footnotetext{
${ }^{20}$ Barbaras, R. "A phenomenology of life". In: Carman, T., Hansen M. (eds.). The Cambridge Companion to Merleau-Ponty. Cambridge: Cambridge Univ. Press, 2005, p.226.

${ }^{21}$ Coghill, G. E. Anatomy and the Problem of Behaviour. New York/London, Macmillan, 1929.

${ }^{22}$ Gesell, A., L'Embryologie du Comportement. Paris: PUF, 1945.
} 
tentam articular de uma maneira inovadora o desenvolvimento anatômico e comportamental. Com base nesses autores, o filósofo formula uma concepção de ontogênese mais vasta que aquela reducionista, segundo a qual decorrem da maturação de estruturas fisiológicas os comportamentos, concebidos como padrões de reação determinadas previamente ${ }^{23}$. Por um lado, Merleau-Ponty acentua que no desenvolvimento embrionário ocorrem certas reações comportamentais que se antecipam aos dispositivos nervosos que os facultariam. Por exemplo, o feto humano, antes mesmo de dispor dos sistemas neurais que coordenam os batimentos cardíacos, apresenta, em algumas situações (ao menos após nove semanas e meia de gestação), sinais cardíacos que se assemelham àqueles de adultos em situações parecidas (Cf. N, 197). Há, assim, potencialidades comportamentais intrínsecas ao embrião que antecedem a especialização anatômica dos centros fisiológicos coordenadores das ações corporais. Para explicar essa antecipação comportamental em relação à maturação neural, Coghill cunha a noção de gradientes: diferentes níveis de suscetibilidade dos tecidos embrionários a impulsos elétricos ou bioquímicos (Cf. N, 191). Por meio desses gradientes, desenvolvem-se as oposições morfológicas do embrião, de maneira a se distinguir, por exemplo, um pólo vegetativo ou posterior e um pólo animal ou anterior. Essa distinção possibilita a distribuição de certas funções correlacionadas com tais pólos morfológicos, e, por conseguinte, torna possível a manifestação de certos comportamentos embrionários pré-neurais. Tais comportamentos não se limitam a manifestar a ativação de estruturas fisiológicas determinadas, uma vez que eles estão inscritos em fases da morfogênese embrionária prévias ao funcionamento de tais estruturas.

Por outro lado, Merleau-Ponty expõe que o desenvolvimento local anatômico do embrião também antecipa a manifestação do seu comportamento. No feto humano com oito semanas, por exemplo, já ocorre o afastamento entre o polegar e os demais dedos das mãos, de modo a configurar um certo padrão anatômico cujo efetivo uso só se manifestará vários meses após o nascimento, quando o bebê aprender a pegar objetos pela oposição entre o polegar e os outros dedos (Cf. N, 197). Esse exemplo evidencia que o corpo, ao menos em seu estado embrionário, se define por uma referência a comportamentos possíveis. A base material do corpo é, assim, aberta a possibilidades ulteriores, que justificam as estruturas anatômicas atuais.

\footnotetext{
23 "O interesse de uma noção como aquela de comportamento é que ela nos permite remontar aquém da estrutura fixa que a anatomia revela" $(\mathrm{N}, 201)$.
} 
Tal como expusemos nos dois parágrafos anteriores, os organismos, julga Merleau-Ponty, devem ser concebidos como sistemas dinâmicos que em seu desenvolvimento, ora por meio dos comportamentos ora por meio da anatomia, antecipam possibilidades sobre seu próprio ser atual, de modo a instaurar um desequilíbrio entre funções comportamentais e aparato orgânico (Cf. N, 207). Esse desequilíbrio revela que os organismos, ao menos no caso do embrião, são como que obsedados por suas possibilidades, no sentido de que seus padrões atuais de organização não se esgotam em si mesmos e impõem uma referência a uma totalidade futura ainda ausente $^{24}$.

No que concerne à nossa discussão acerca do excesso do ser em relação ao ser sensível, importa notar que na ontogênese animal a coesão do organismo se forma por referência a uma totalidade invisível (Cf. N, 303). Existe uma negatividade operante na ordenação da vida, quer dizer, o organismo não se reduz àquilo que pode ser positivamente apreendido pela percepção. É verdade que o exemplo do mimetismo mostrara que o organismo se ordena para uma percepção possível, e que, por conseguinte, ao menos parte de seu ser é sensibilidade iminente. No entanto, os estudos da embriologia mostram que o organismo não se reduz àquilo que se manifesta perceptivelmente; pois há nele uma referência a estruturas anatômicas ou padrões comportamentais futuros, ordenados como uma Gestalt ausente, cuja totalidade não está em correlação com nenhuma percepção possível. Essa totalidade ausente pela qual os desequilíbrios inerentes ao desenvolvimento ontogenético se rearranjam em equilíbrios futuros parece funcionar como um princípio ou dimensão invisível pela qual a vida se ordena. Como veremos em nossa conclusão, será por meio da noção de dimensões invisíveis, ou seja, de eixos inaparentes pelos quais uma multiplicidade de fenômenos se organiza, que Merleau-Ponty defenderá uma diferença irredutível entre o ser e o ser percebido ${ }^{25}$.

\footnotetext{
24 "Em virtude de sua iniciativa endógena, o organismo traça o que será sua vida futura, ele desenha seu meio (Umwelt); ele contém um projeto em referência ao todo de sua vida" (N, 202).

${ }^{25}$ As análises acerca da embriologia exemplificam essa diferença, a qual é tratada de maneira mais explícita nas notas de trabalho de $O$ Visível e o Invisível. Deve-se notar que as análises dos organismos como entes que envolvem uma negatividade não apreensível diretamente implicam uma mudança de concepção em relação a algumas teses de A Estrutura do Comportamento. Nesse livro, o organismo era definido como "um conjunto significativo para uma consciência que o conhece, não uma coisa que repousa em si" (SC, 172). Já em A Natureza, embora não seja definido como uma coisa em si, o organismo, em sua totalidade, não está em correlação com alguma consciência perceptiva, pois é entrecortado por elementos negativos, que excedem aquilo que é apreensível positivamente.
} 
Conforme nossa interpretação, não é correto afirmar que Merleau-Ponty identifica o ser a estruturas sensíveis que se manifestam para a percepção humana, tal como Barbaras propõe. A identificação entre o ser e o aparecer sensível tornaria difícil a compreensão da negatividade operante pela qual se tenta esclarecer o desenvolvimento ontogenético. E, de fato, notamos dificuldades na exposição de Barbaras sobre esse tema. Como vimos, em sua interpretação de Merleau-Ponty, esse autor define a realidade em termos de fenomenalidade: o ser não é nada mais que aquilo que se manifesta para a percepção. Isso não ocorreria porque o ser dependeria da consciência, mas porque em si mesmo o ser é sensibilidade iminente ${ }^{26}$. Embora não dependa da consciência, o ser, porque se constitui como sensibilidade, é "correlativo com o sentido subjetivo",27, ou seja, sua organização é exatamente aquela apreendida pela percepção, defende Barbaras. Ora, não parece possível definir a totalidade ausente do organismo (já que ela envolve possibilidades que não são perceptíveis atualmente) como fenomenal. No entanto, é o que Barbaras sugere; para ele o organismo enquanto totalidade que excede suas partes atuais "existe para alguém, envolve referência a um ponto de vista" ${ }^{28}$. Qual justifica Barbaras fornece para sua interpretação? Segundo esse autor, a totalidade ausente do organismo "é fenomenal no sentido que é irredutível a eventos microscópicos (físico-químicos); ela pressupõe um ponto de vista" ${ }^{29}$. Assim, para rejeitar a redução da totalidade do organismo a eventos objetivos dever-se-ia aceitar que ela se manifesta para uma percepção possível. Barbaras parece supor aqui um dilema (ou o ser é objetivo, conjunto de múltiplos eventos em si, ou é fenomenal, voltado para uma percepção subjetiva) com o qual Merleau-Ponty, ao menos em seus textos maduros, não concorda. Parece-nos que o filósofo define a totalidade do organismo como uma negatividade que não se manifesta e que não se dirige a nenhum ponto de vista privilegiado que a apreenderia, embora, mesmo assim, regule o desenvolvimento orgânico. Desse modo, a totalidade ausente do organismo, ainda que não se reduzindo a uma reunião de processos físico-químicos atuais, não confirma o caráter fenomenal do ser, mas, antes, rompe a identificação entre ser e manifestar-se.

Aqui poderia nos ser objetado que os aspectos que formam essa totalidade ausente são potencialmente apreensíveis pela percepção humana. Na Fenomenologia da Percepção, defendia-se que embora a totalidade do ser do mundo não seja atualmente

\footnotetext{
${ }^{26}$ Cf. Barbaras, R. “A phenomenology of life”. Ed. supra, p.226.

${ }^{27}$ Id., ibid.

${ }^{28}$ Ibid., p.224.

${ }^{29}$ Ibid., p.225.
} 
voltada para a apreensão subjetiva, aquilo que escapa a tal apreensão atual em nada excede as estruturas subjetivas, já que caso tais elementos excedentes se atualizassem, se ordenariam de forma plenamente apreensível pelas capacidades perceptivas (Cf. PhP, 269-70, 377). A objeção em pauta tenta fazer valer a noção de projeto de todo ser possível, que Merleau-Ponty atribuía às capacidades perceptivas na Fenomenologia da Percepção, para as análises de A Natureza. Assim, as estruturas futuras que obsedam o campo presente do embrião seriam plenamente apreensíveis pela percepção humana, o que se confirmaria, por exemplo, quando da sua maturação, na idade adulta do organismo. Nesse estágio, comprovar-se-ia facilmente que os comportamentos ou sistemas fisiológicos que apenas potencialmente coordenavam o embrião são ordenados de maneira sensível. De nosso ponto de vista, a objeção em questão supõe 1) que todas as possibilidades que incitam o desenvolvimento orgânico vão se atualizar, e 2) que aquelas possibilidades que de fato se atualizam são ordenadas de modo a serem perfeitamente apreendidas pela subjetividade.

Quanto à primeira suposição, não é obvio que tal atualização plena ocorra. Podese admitir razoavelmente que o aparato orgânico possibilita diferentes padrões comportamentais (dos quais nem todos se atualizam), e que os comportamentos sempre podem antecipar alterações fisiológicas não perceptíveis e nem mesmo previsíveis (tais como no caso de mutações genéticas), e isso no decorrer de toda a vida orgânica, devido à exposição a inúmeros fatores ambientais. Assim, a maturação do embrião, a passagem à fase adulta, não valeria como prova de que a totalidade ausente que o obsedava de fato se tornou estrutura manifesta. $\mathrm{O}$ excesso de possibilidades sobre o ser atual pode definir a existência inteira do organismo, de modo que mesmo os indivíduos adultos nunca se reduziriam àquilo que sensivelmente aparece. O organismo sempre envolveria uma latência invisível (ou seja, desequilíbrios inaparentes entre seu aparato anatômico e comportamental) pela qual sua existência se ordenaria.

Quanto à segunda suposição, não é óbvio que todas as estruturas anatômicas ou comportamentais que se atualizam na existência do organismo se ordenem de um tal modo que seu ser se identifica com aquilo que a percepção humana deles apreende. Por exemplo, Merleau-Ponty apresenta a organização dos pólos morfológicos do embrião por meio dos gradientes, os quais são concebidos como processos de diferenciação invisível (Cf. N, 307). Provavelmente, o filósofo considera que os processos de reconhecimento dos limiares bioquímicos ou elétricos pelos tecidos embrionários não são fenômenos perceptíveis no mesmo sentido em que o levantar do sol ou o quebrar 
das ondas são. Nesses últimos casos, trata-se de eventos macroscópicos que se manifestam para a percepção ingênua antes mesmo de qualquer reflexão acerca da sua veracidade. Por sua vez, a "percepção" do funcionamento dos gradientes envolve inúmeros pressupostos teóricos e só se torna possível após a elaboração de complexas hipóteses e pelo uso de poderosos artefatos técnicos que traduzem eventos microscópicos em dados compreensíveis cientificamente. Não é, assim, claro que todos os processos do desenvolvimento ontogenético sejam de fato diretamente perceptíveis e estejam em correlação com o sentido subjetivo, tal como parece propor Barbaras.

Com efeito, Merleau-Ponty não exige tal correlação. Afinal, seu estudo da embriologia não foi desenvolvido como extração de conseqüências de certos dados sensíveis fornecidos imediatamente pela percepção. Ao discutir a ontogênese animal, o filósofo não parece descrever eventos percebidos, assim como a Fenomenologia da Percepção descrevia a apreensão imediata de um cinzeiro ou de uma chaminé. Os dados obtidos pela análise dos organismos não provêm dos conteúdos da percepção, e nem servem, desse modo, para uma confirmação do caráter eminentemente perceptível da totalidade do ser. Na verdade, ao citar a embriologia, Merleau-Ponty parece ter suspendido as evidências da percepção e apelado a outra fonte de dados para sua reflexão. Não se trata mais de descrever aquilo que se manifesta para a consciência perceptiva, mas de se servir de dados científicos para esclarecer os temas em questão. Entrevê-se aqui uma mudança significativa de metodologia. A Fenomenologia da Percepção sugeria como gesto filosófico por excelência o retorno à experiência perceptiva pré-objetiva, a qual deveria ser descrita sem distorções objetivistas ${ }^{30}$. Por sua vez, em A Natureza, Merleau-Ponty assume um método por meio do qual tenta caracterizar o ser não por uma descrição dos conteúdos apreendidos pela percepção (e então definidos como medida de tudo o que existe), mas por uma análise de diferentes resultados científicos. Vamos expor, no próximo capítulo, as alterações teóricas implicadas por tal método em comparação com as teses da Fenomenologia da Percepção.

\footnotetext{
30 "O primeiro ato filosófico seria então retornar ao mundo vivido aquém do mundo objetivo, já que é nele que poderemos compreender os direitos e os limites do mundo objetivo" (PhP, 69).
} 


\section{Capítulo IV - O método indireto da ontologia madura de Merleau-Ponty}

\section{Sinopse}

De início, retomamos como Merleau-Ponty, desde suas primeiras obras, desenvolve sua reflexão com base em dados fornecidos pelas ciências. Em seguida, mostramos que, no final dos anos cinqüenta, Merleau-Ponty generaliza esse método de circunscrição indireta dos temas filosóficos e se serve da análise de fatos históricos e produções culturais como fonte de dados para sua investigação. Por fim, esclarecemos de que maneira, segundo o filósofo estudado, a escrita filosófica deve desenvolver suas teses com base em tais dados obtidos indiretamente.

\section{A) Filosofia e ciência}

\section{Convergências}

No capítulo anterior, vimos que Merleau-Ponty recorreu a resultados científicos acerca de diferentes âmbitos da natureza para esboçar uma investigação do ser primordial, o qual é anterior à e independente das capacidades humanas. Neste capítulo, pretendemos esclarecer a legitimidade desse recurso a dados científicos e acompanhar como Merleau-Ponty formula e justifica o método indireto pelo qual desenvolve sua última ontologia. Vamos expor, de início, como o filósofo, no decorrer de sua obra, se relaciona com as ciências.

É possível reconhecer uma dupla atitude de Merleau-Ponty no que concerne às ciências. Por um lado, o filósofo sempre sustentou um diálogo fecundo com as disciplinas científicas de seu tempo, e sempre se serviu dos resultados dessas últimas para alimentar sua reflexão. Por outro, essa proximidade amistosa jamais implicou a redução da filosofia seja a um comentário acerca dos resultados obtidos pelas doutrinas científicas seja a uma discussão dos métodos de produção de conhecimento, os quais seriam exclusivamente utilizados pelas ciências. Merleau-Ponty defende, assim, haver tarefas eminentemente filosóficas, que não poderiam ser realizadas pelas ciências (ao menos não pelas ciências tais quais tradicionalmente exercidas, como veremos). Explicitemos com mais detalhes os dois lados da posição do filósofo.

Devemos notar, primeiramente, que o recurso às ciências não é um procedimento esporádico ou secundário na obra de Merleau-Ponty. O debate com as doutrinas científicas percorre, por exemplo, toda A Estrutura do Comportamento, seu primeiro livro. Ali, o filósofo censura a abordagem que reduz o comportamento à 
fisiologia dos reflexos. Tal censura não decorre de um ponto de vista puramente filosófico; é a Gestalttheorie, outra doutrina científica, que fornece as bases para a crítica às teorias reducionistas e para o estabelecimento de uma nova concepção do comportamento. A abordagem metodológica da Gestalttheorie possibilita uma investigação que não reduz o comportamento a reações físico-químicas corporais. Não se trata, por sua vez, de apelar à interioridade da consciência para salvaguardar a irredutibilidade do comportamento. Na verdade, contrário a esse último apelo, MerleauPonty reconhece na Gestalttheorie o advento de um método objetivo de apreensão da atividade comportamental, o qual prescinde do recurso a dados inobserváveis, obtidos por introspecção. Esse método busca fixar a estrutura da conduta, quer dizer, o sentido manifestado pelos fenômenos em causa. Esse sentido pode ser apreendido seja pela notação das respostas comportamentais ante os estímulos seja pelos relatos verbais, que interpretam as próprias reações. Assim, em um teste psicológico, tanto uma criança que deve falar quais cores são semelhantes quanto um símio que separa as fichas de cor idêntica em pires diferentes explicitam uma mesma conduta comportamental (Cf. SC, 198). Por meio de palavras ou de gestos, interessa, no caso, avaliar a capacidade de distinção cromática. Para tanto, não é preciso apelar para vivências privadas. A realidade psíquica a ser investigada se manifesta na conduta observável, crê MerleauPonty.

Na Fenomenologia da Percepção, o método enaltecido por A Estrutura do Comportamento é assumido como resposta às possíveis objeções de que as descrições de experiências percebidas se limitariam ao registro de vivências privadas. Na verdade, em tais descrições, trata-se de explicitar o sentido pelo qual espontaneamente os fenômenos se ordenam (Cf. PhP, 70). Esse sentido é apreendido do mesmo modo como os psicólogos anotam a conduta dos sujeitos investigados: em ambos os casos, registrase uma ordenação pública de dados. A fenomenologia, assim como a psicologia que estuda as estruturas concretas, não descreve dados introspectivos, mas eventos observáveis.

Nos cursos reunidos em Psicologia e Pedagogia da Criança, Merleau-Ponty reconhece que a apreensão de estruturas significativas observáveis não é uma meta exclusiva da fenomenologia, uma vez que certos cientistas também a buscam. MerleauPonty cita o estudo de Köhler sobre o comportamento de macacos (Cf. PPE, 13-14). Esse cientista não apresenta os resultados de suas pesquisas apenas em termos quantitativos, mas utiliza termos que exprimem o modo como certas situações estudadas 
são apreendidas qualitativamente pelos observadores. Por exemplo, os macacos estudados podiam não apenas chegar aleatoriamente à solução dos problemas; por vezes eles "resolviam ativamente" o desafio em questão, ou por vezes ocorria o "bom erro" com o qual eles aprendiam. Esses resultados exprimidos com termos qualitativos parecem padecer de um certo antropomorfismo, uma vez que supõem o modo como a subjetividade do cientista apreende a situação em pauta. No entanto, segundo MerleauPonty, esse aparente antropomorfismo é, na verdade, uma característica indispensável de uma pesquisa que se preocupa em exprimir a situação investigada tal como ela se mostra. A investigação de Köhler não ignora a estrutura fenomenal dos casos estudados, ou seja, o modo como eles se manifestam para a subjetividade cognoscente. Köhler, assim como Merleau-Ponty na Fenomenologia da Percepção, admite que a manifestação fenomenal dos eventos estudados não é uma mera camada subjetiva que se poderia dispensar em prol de uma suposta objetividade puramente quantitativa. É necessário registrar o sentido contido em tal manifestação como componente irredutível dos eventos estudados.

O exemplo de Köhler confirma que para Merleau-Ponty a ciência, quando estuda o sentido manifestado nas estruturas fenomênicas, se aproxima da filosofia. Tal como o filósofo francês afirma em Titres et Travaux, texto editado em Parcours II: o método da filosofia concreta "está bem longe de ser reservado apenas aos filósofos, sobretudo na ciência de hoje, mais afastada do que nunca de se limitar à indução empírica" (PII, 25). Ocorre, dessa maneira, uma extraordinária convergência entre as pesquisas desenvolvidas pelos pesquisadores de tais estruturas e as intenções da filosofia fenomenológica, pois esta última visa circunscrever um campo subjetivo por meio do qual o acesso ao mundo objetivo tornar-se-ia possível (Cf. PhP, 69-71). Com tal convergência como pano de fundo, Merleau-Ponty chega mesmo a afirmar em um debate de 1952 que "distinguir aqui entre o cientista e o filósofo é fazer uma distinção que não corresponde a nada de efetivo" (PII, 375). Com essa afirmação, Merleau-Ponty rejeita que haja alguma incompatibilidade de princípio entre ciência e filosofia. A filosofia não é um encadeamento de puras idéias, mas tentativa de explicitar o sentido das situações em que o ser humano está inserido. Por sua vez, a ciência não é mera reunião de dados empíricos, pois implica uma elaborada reflexão conceitual acerca dos problemas de que trata. Desse modo, ciência e filosofia, compreendidas como tentativa de elucidação da experiência concreta, podem se ajudar consideravelmente. 


\section{Divergências}

Apesar do entusiasmo com as pesquisas científicas que se aproximam da fenomenologia, de maneira a praticamente reconhecer a indistinção entre ambas em certos casos privilegiados, Merleau-Ponty resguarda a autonomia da filosofia ante a ciência: a reflexão filosófica não deve se limitar a assimilar ou comentar dados positivos das pesquisas científicas. E assim como o recurso a tais dados se faz notar já nas primeiras obras de Merleau-Ponty, do mesmo modo o filósofo sempre manteve uma postura crítica ante certos compromissos teóricos que viciam os resultados científicos.

Merleau-Ponty não defende que a ciência padece de deformações congênitas irremediáveis, como se por princípio não pudesse reconhecer a complexidade dos fenômenos do mundo. Já no início de A Estrutura do Comportamento, o filósofo admite que a física utiliza "indiferentemente modelos mecânicos, dinâmicos ou mesmo psicológicos, como se, liberada de pretensões ontológicas, ela se tornasse indiferente às antinomias clássicas do mecanicismo e do dinamismo, que supõem uma natureza em si” (SC, 1). Aqui a física exemplifica que, ao menos em princípio, as investigações científicas não estão presas a nenhuma concepção metafísica em particular. A atividade científica busca explicar determinados conjuntos de eventos por meio de modelos teóricos, os quais não estão de antemão comprometidos com nenhuma ontologia. Como afirma o resumo do primeiro curso sobre a natureza, "é impossível recusar [a ciência] antecipadamente sob o pretexto de que ela trabalha na linha de certos prejuízos ontológicos" (N, 368). Os cientistas, ao menos idealmente, contam com uma tal liberdade na formulação das teorias que nenhuma concepção metafísica (a qual poderia obscurecer a apreensão de certos aspectos da realidade) é antecipadamente favorecida.

A ciência porta idealmente, reconhece Merleau-Ponty, a possibilidade de explorar a complexidade do mundo sem desqualificar, por preconceito metafísico, nenhum fenômeno. $\mathrm{O}$ fato de que algumas pesquisas psicológicas praticamente se identifiquem às descrições fenomenológicas, tal como vimos na subseção anterior, exemplifica essa plasticidade ontológica inerente à atividade científica. No entanto, e aqui a divergência de Merleau-Ponty em relação à ciência se explicita, historicamente a maior parte das pesquisas cientificas se desenvolveu conforme uma metodologia que favorece uma concepção metafísica bastante discutível. Essa metodologia busca isolar os componentes materiais dos fenômenos, os quais supostamente formariam uma infraestrutura compreensível apenas matematicamente. Os dados visados por tal metodologia são considerados inacessíveis pelas capacidades perceptivas, as quais seriam então 
incapazes de desvendar a realidade última dos eventos. Anuncia-se aqui a tese ontológica vinculada a tal metodologia científica: a realidade deve ser considerada como um conjunto de eventos ou propriedades cuja ordenação é completamente independente de e inacessível para as capacidades perceptivas humanas.

Chamemos tal opção metodológica e suas conseqüências ontológicas de objetivismo, ou seja, uma postura teórica segundo a qual a realidade última do mundo é independente de seu modo de manifestação para a subjetividade. É essa opção metodológica que impede uma maior integração entre ciência e filosofia, pois a ciência praticada de maneira objetivista não abarca todos os problemas vislumbrados pela filosofia, de maneira a tornar legitimo o desenvolvimento de uma investigação filosófica autônoma. A postura objetivista tende a ignorar o sentido das estruturas concretas percebidas, o qual é reduzido a um mero efeito psicológico da ordenação real dos dados. Por sua vez, tal ordenação só seria desvelada ao se formular leis gerais que descreveriam as propriedades inobserváveis do mundo, aquelas que verdadeiramente constituiriam os eventos estudados. Dessa maneira, a investigação objetivista da natureza atribui um caráter secundário à manifestação sensível em relação $a$ uma infraestrutura plenamente abstraída da apreensão subjetiva das situações vividas. Se os resultados da ciência são tomados como único acesso seguro aos componentes do mundo e única fonte confiável para a elaboração de uma ontologia (tal como MerleauPonty julga que eles assim foram tomados na época do Pequeno Racionalismo, século XIX), então, sob regime objetivista, o ser é concebido como infra-estrutura destituída de qualidades sensíveis ${ }^{1}$. Contra tal conseqüência, Merleau-Ponty rejeita a definição da realidade tal como fornecida pela ciência objetivista, e, inspirado pelo Grande Racionalismo do século XVII (em que ciência e metafísica conviviam harmonicamente), esforça-se por formular uma nova noção de ser, a qual, sem se reduzir ao ser objeto da ontologia objetivista, inclua toda a riqueza dos fenômenos percebidos.

Vimos, ao citar o exemplo da Gestalttheorie, que certas pesquisas científicas tentam romper com o objetivismo ao considerar o sentido inerente às estruturas percebidas como elemento ontológico irredutível a uma infra-estrutura puramente

\footnotetext{
${ }^{1}$ Husserl já havia notado esse corolário ao comentar a matematização da Física moderna. Para ele, o procedimento de obtenção de formas geométricas ideais (exatas) sobre os dados sensíveis sugeriu uma interpretação metafísica errônea, a qual toma "pelo Ser verdadeiro o que é método" (Husserl, E. Die Krisis der europäischen Wissenschaften und die transzendentale Phänomenologie. Ed. supra, § 9h, p.52), quer dizer, a qual supõe a existência de um mundo plenamente objetivo por trás das formas sensíveis dadas na percepção.
} 
quantitativa. Porém, essas iniciativas são bastante restritas, quase que se limitando em sua totalidade à psicologia ou a algumas áreas da fisiologia. Elas não implicam, assim, a elaboração de uma alternativa metodológica geral ao objetivismo. Além disso, tal como já aparece em A Estrutura do Comportamento, tais iniciativas não estão completamente livres dos pressupostos objetivistas. Nesse livro, Merleau-Ponty lamenta que as conclusões da Gestalttheorie tendam para um tipo de objetivismo materialista (Cf. SC, 144). Isso ocorreria porque os cientistas da Gestalttheorie defendem que a organização gestáltica dos eventos biológicos em geral e aqueles da consciência humana são redutíveis à organização gestáltica de eventos físicos. Dessa maneira, os fenômenos ligados à vida e ao pensamento seriam efeitos de uma infra-estrutura material, passível, em princípio, de ser estudada objetivamente. Ante essa postura reducionista, MerleauPonty lamenta que "as categorias da ciência não são feitas para os fenômenos que ela mesma colocou em evidência" (SC, 33). O filósofo salienta que embora muitas pesquisas científicas ofereçam resultados que poderiam fomentar uma renovação acerca do entendimento mais geral sobre os eventos mundanos, tais resultados são normalmente interpretados segundo os cânones da ontologia objetivista, de maneira que quaisquer novidades ontológicas neles contidas não são adequadamente desenvolvidas. A tarefa filosófica é justamente conceber as novas categorias pelas quais os fenômenos que não se conformam aos padrões objetivistas (embora a eles sejam arbitrariamente reduzidos) possam ser compreendidos em toda a sua complexidade (Cf. SC, 84).

Esse é o caso dos fenômenos de Gestalt. Para Merleau-Ponty, os próprios cientistas da Gestalttheorie insistiram em que nenhuma Gestalt pode ser remetida a causas exteriores externas à sua ordenação imanente (Cf. SC, 144). Ora, para que se assuma efetivamente tal tese, é necessário rejeitar a redução das Gestalten de eventos biológicos ou da consciência humana à Gestalten físicas. Por sua vez, essa rejeição implica assumir a especificidade do nível em que as primeiras se manifestam. As Gestalten da percepção humana, por exemplo, não devem, então, ser reconduzidas a eventos físicos no cérebro do sujeito perceptivo. Merleau-Ponty não nega a importância do substrato neuronal para a percepção; porém, o filósofo defende que os padrões de organização perceptiva se devem a processos de segregação inerentes ao próprio campo fenomenal ${ }^{2}$. Assim, de maneira geral, a compreensão de certos eventos exige que as

\footnotetext{
${ }^{2}$ Segundo Merleau-Ponty, "o funcionamento nervoso que distribui aos diferentes pontos do campo sensorial seus valores espaciais ou cromáticos e que, por exemplo, nos casos normais torna impossível a diplopia, não é concebível sem referência ao campo fenomenal e a suas leis de equilibro interior" (SC,
} 
estruturas manifestadas pela percepção sejam tomadas como constituintes últimos da realidade, e não como efeitos de uma infra-estrutura objetiva. Na Fenomenologia da Percepção, Merleau-Ponty desenvolve a idéia de que o ser fenomenal é irredutível ao ser objetivo. Esse último seria composto por atributos unívocos e exatos; já o ser fenomenal seria em si mesmo indeterminado (sem limites ou medidas precisas) e ambíguo (comporta diferentes sentidos) (Cf. $\mathrm{PhP}, 12,18$ ). Essas características implicam que os eventos fenomenais não são assimiláveis pelos padrões das investigações estritamente objetivas: não é possível isolar sua infra-estrutura material sem a correspondente perda de algumas de suas propriedades mais importantes. E por salientar essa originalidade do ser fenomenal ou percebido como constituinte irredutível da realidade, a filosofia desenvolvida por Merleau-Ponty mantém sua autonomia em relação à ciência, a qual, em sua maior parte, se realiza segundo uma metodologia objetivista.

\section{O método indireto}

A investigação do ser fenomenal, a qual oferece uma nova base teórica para a compreensão de certos eventos explicitados pela ciência (tais como os fenômenos de Gestalt), garante, nas primeiras obras de Merleau-Ponty, a irredutibilidade da filosofia à ciência. Além disso, tal investigação atesta que a obtenção indireta de dados para a reflexão ontológica (ou seja, obtenção por meio da referência às disciplinas nãofilosóficas) já está presente em A Estrutura do Comportamento, primeira obra de Merleau-Ponty ${ }^{3}$. Conforme acabamos de expor, nesse livro, o autor se apropria de alguns resultados obtidos pela Gestalttheorie para rejeitar as concepções reducionistas do comportamento e da vida perceptiva. Em seguida, na Fenomenologia da Percepção, tenta desenvolver a noção de ser fenomenal ou percebido como uma categoria que proporciona uma renovação das concepções ontológicas clássicas e permite compreender adequadamente os fenômenos de Gestalt.

Vale notar que no livro de 1945, Merleau-Ponty continua a utilizar um método indireto de reflexão. A explicitação de algumas das principais características do corpo próprio ocorre por meio do estudo de casos patológicos, os quais permitem revelar por

207). Além disso, o filósofo sustenta que “o espetáculo de uma coisa vista através de seus 'perfis', essa estrutura original não é nada que possa ser 'explicado' por algum processo fisiológico ou psicológico real" (SC, 209).

${ }^{3}$ Luiz Damon Moutinho explicita esse tema no início de seu livro Razão e Experiência - Ensaio sobre Merleau-Ponty. Ed. supra, conforme mencionamos na introdução. 
contraste os componentes do funcionamento normal das intencionalidades corporais ${ }^{4}$. No entanto, parece-nos haver uma diferença crucial entre a reflexão indireta contida na Fenomenologia da Percepção e aquela realizada nos escritos mais tardios, nos quais o filósofo explicitamente admite usar um "método indireto". No livro de 1945, o escopo da reflexão indireta parece delimitado por uma concepção de ser formulada de maneira direta. Como vimos em nosso primeiro capítulo, Merleau-Ponty define o ser, nesse livro, como ser percebido, e restringe aquilo que pode existir àquilo que pode se manifestar à consciência $(\mathrm{Cf} . \mathrm{PhP}, 455)$. Notemos que essa definição não resulta da aplicação de uma reflexão indireta, ou seja, da análise de dados oriundos de disciplinas não-filosóficas. Merleau-Ponty parece tê-la obtido por confiar em que a percepção apresenta o mundo tal como é, e que, conversamente, o ser do mundo não excede aquilo que a percepção apresenta $(\mathrm{Cf} \text {. } \mathrm{PhP}, \mathrm{X}-\mathrm{XI})^{5}$. Desse modo, a reflexão indireta contida na Fenomenologia da Percepção ocorre conforme os limites de uma concepção do ser que não é derivada de tal reflexão. Já nos textos finais, o método indireto será utilizado justamente para elaborar a própria noção geral de ser. Nesses textos, como veremos, não há uma delimitação prévia daquilo que é o ser, no interior da qual o apelo às disciplinas não-filosóficas somente auxiliaria a desvendar alguns fenômenos. O apelo a tais disciplinas será fundamental para compreender o que é o próprio ser do mundo.

Vimos, no capítulo anterior, que ao menos a partir do primeiro curso sobre a natureza (1956), Merleau-Ponty não mais limita aquilo que existe àquilo que é apreensível pela atividade perceptiva, mas passa a considerar um ser primordial, cuja ordenação é anterior às capacidades subjetivas e delas independente. Essa consideração decorre do uso generalizado do método indireto, quer dizer, da sua aplicação para construir a própria idéia de ser (e não como técnica que supõe uma definição prévia do ser como ser percebido). Na Fenomenologia da Percepção, Merleau-Ponty supunha que o sujeito perceptivo portava um projeto de todo ser possível, de modo que as

\footnotetext{
${ }^{4}$ Ao observar as abundantes referências de Merleau-Ponty a estudos psicológicos, pode-se mesmo sugerir que toda a primeira parte da Fenomenologia da Percepção, dedicada ao corpo, e boa parte da segunda, dedicada ao mundo, foram construídas com base numa reflexão indireta.

${ }^{5}$ Nas poucas vezes em que se refere a conhecimentos que excederiam aqueles apreensíveis pela percepção, Merleau-Ponty atribui caráter secundário a tais dados ante a experiência perceptiva direta: "o sol 'se levanta' tanto para o cientista quanto para o ignorante, e nossas representações científicas do sistema solar permanecem da ordem do dizem que, assim como as paisagens lunares, nas quais nós nunca acreditamos no sentido em que acreditamos no nascer do sol" (PhP, 396). Desse modo, o saber acerca da astronomia heliocêntrica permanece secundário ante a experiência perceptiva. É que na Fenomenologia da Percepção, Merleau-Ponty defende que "a experiência dos fenômenos (...) é a explicitação (...) da vida pré-científica da consciência, que é a única a dar sentido completo às operações da ciência e à qual essas sempre reenviam" ( $\mathrm{PhP}, 71)$. Por conseguinte, nenhum dado científico poderia desmentir ou mesmo relativizar o veredicto da percepção, já que dependeria desse último para fazer sentido.
} 
articulações encontradas nos eventos mundanos eram exatamente aquelas reconstituídas pelos poderes perceptivos humanos (Cf. $\mathrm{PhP}, 411)$. No entanto, ao investigar o ser primordial, o filósofo parece não mais assumir essa suposição. É verdade que ainda é afirmado que em sua própria organização o ser se abre para uma percepção possível e, assim, confirma-se como eminentemente sensível. Porém, conforme vimos em relação aos dados da embriologia, também é verdade que Merleau-Ponty reconhece uma negatividade operante no interior do ser, a qual não se doa de maneira positiva à percepção. A investigação do ser primordial, por conseguinte, não se limita à descrição de estruturas mundanas perceptíveis em correlação com poderes subjetivos.

Para o estudo do ser primordial, o apelo aos dados científicos se torna crucial. Muitos eventos, tal como a ordenação de tecidos embrionários por meio de gradientes bioquímicos exemplifica, nem mesmos seriam notados se não se recorresse a pesquisas científicas e se se confiasse somente na descrição da experiência perceptiva ingênua. Daí que, para descrever o ser em toda a sua complexidade, não basta se limitar àquilo que é apreendido perceptivelmente de maneira imediata. É necessário recorrer a uma abordagem indireta para que certas propriedades sejam apreendidas, quer dizer, referirse a hipóteses científicas e aos respectivos testes que confirmam as conseqüências por elas previstas. Mas ainda que o apelo a dados científicos seja indispensável para caracterizar um ser que não se restringe ao que é perceptível imediatamente, a reflexão indireta de Merleau-Ponty não se reduz a um comentário de determinadas teorias. Em seus textos finais, o filósofo volta a criticar a opção objetivista pela qual as pesquisas científicas normalmente são realizadas e volta a afirmar a autonomia da filosofia.

Essa perspectiva crítica se explicita, por exemplo, em $O$ Olho e Espírito, texto publicado em 1961. Ali, Merleau-Ponty critica os procedimentos metodológicos científicos que tratam "todo ser como 'objeto em geral', isto é, ao mesmo tempo como se ele nada fosse para nós, e, no entanto, se achasse predestinado aos nossos artifícios" (OE, 9). Por um lado, a metodologia objetivista afirma que a realidade mundana se compõe de uma infra-estrutura material independente da assimilação subjetiva da experiência. Por outro, reconhece que tal infra-estrutura pode ser apreendida pela linguagem matemática e pelos instrumentos técnicos, sem se questionar em que medida tal linguagem e tais instrumentos também não são somente diferentes formas subjetivas de se relacionar com o mundo. Segundo Merleau-Ponty, ao definir a realidade como conjunto de objetos, isto é, entes compostos por propriedades determináveis matematicamente, o pensamento objetivista tende para um "artificialismo absoluto" 
(OE, 12), pois concebe a realidade como plenamente apreensível por procedimentos técnicos, quer dizer, como redutível àquilo que as teorias científicas nela distinguem.

Merleau-Ponty recusa conceber o mundo como um conjunto de propriedades manipuláveis pelas técnicas científicas. Anuncia-se aqui novamente uma tarefa ontológica para a filosofia. Assim como em A Estrutura do Comportamento a distorção interpretativa dos dados científicos fomentava a busca filosófica por uma renovação conceitual, nos últimos textos de Merleau-Ponty o pensamento operatório ou objetivista pelo qual a ciência se realiza (o qual reduz a realidade a um conjunto de objetos submetido a técnicas de manipulação) deixa espaço para a investigação de um ser que não se reduz a propriedades manipuláveis tecnicamente. Deve-se notar que não se trata mais, nesses últimos textos, de marcar a distância entre ciência e filosofia porque a primeira ignora a especificidade do ser fenomenal ou percebido, tal como MerleauPonty fizera na Fenomenologia da Percepção. Afinal, o ser primordial que MerleauPonty pretende descrever em seus textos finais não se limita àquilo que pode estar em correlação direta com as capacidades perceptivas. O ponto de discordância com a ciência, nesses textos, é que essa última só reconhece como ser aquilo que é objeto manipulável pelo instrumental técnico disponível, uma restrição a que o ser primordial, composto por dimensões negativas que escapam mesmo à apreensão perceptiva, não se submete.

\section{O duplo papel da ciência}

Deve-se notar que a ciência será não somente meio pelo qual essa nova investigação ontológica se realizará mas também tema a ser tratado por ela. Vejamos com mais detalhes ambos os papéis neste e no próximo parágrafo. Como meio, a ciência oferece dados para a reflexão filosófica, tal como os cursos de A Natureza, analisados no capítulo anterior, exemplificaram ${ }^{6}$. Quanto a esse aspecto, Merleau-Ponty sustenta em algumas passagens que as contribuições mais relevantes da ciência para a reflexão filosófica são negativas, no sentido de refutar algumas das concepções clássicas dos temas em questão ${ }^{7}$. A física relativista e a mecânica quântica, por exemplo, invalidam a concepção determinista da natureza formulada por Laplace. Desse modo, as doutrinas científicas eliminam teses metafísicas que distorcem os fenômenos. No entanto, vimos

\footnotetext{
${ }^{6}$ Segundo Merleau-Ponty, todo filósofo deveria pensar seus temas "com base na experiência sob sua forma mais rigorosa, quer dizer, com base na ciência" $(\mathrm{N}, 120)$.

7 A ciência "tem somente o poder de destituir as pseudo-evidências do seu pretenso caráter de evidência" $(\mathrm{N}, 145)$
} 
no capítulo anterior que Merleau-Ponty parece se servir de alguns dados positivos oriundos de investigações científicas, tais como aqueles fornecidos pelo estudo do mimetismo e da embriologia. Estaria assim Merleau-Ponty sendo infiel ao seu próprio princípio segundo o qual a ciência só auxilia a compreender o que o ser não é, mas nunca $o$ que ele é? Julgamos que não. Merleau-Ponty se serve dos dados científicos para descobrir "no desenvolvimento do saber os sintomas de uma nova tomada de consciência da Natureza" (N, 357), ou seja, para aí encontrar os índices de uma renovação ontológica por se fazer. Mas esses índices, esses sintomas não são teses ontológicas prontas, que o filósofo simplesmente recolheria nas doutrinas científicas. Merleau-Ponty alerta: "certamente, não se deve pedir à ciência uma nova concepção da Natureza, toda feita" (N, 120). Os dados extraídos dos estudos sobre o mimetismo e a embriologia não são em si mesmos asserções ontológicas, mas informações que apontam para certas idéias que o filósofo desenvolve por sua própria conta. Por exemplo, a teoria do mimetismo não afirma que uma certa camada do mundo é eminentemente sensível (propriedade partilhada por pelo corpo humano), mas somente descreve o fenômeno em questão e dele oferece explicações em conformidade com as teorias gerais aceitas em biologia. A tese ontológica de que há um estofo sensível comum ao mundo e aos corpos se deve à reflexão filosófica. Do mesmo modo, as teorias da embriologia não defendem que há dimensões negativas do ser; essa é uma tese filosófica erigida sobre alguns dados fornecidos por tais teorias, mas uma tese já exterior a tais doutrinas. Assim, é verdade que Merleau-Ponty localiza índices importantes para uma nova ontologia em alguns resultados científicos; porém, tais índices não são por si mesmos teses ontológicas, de maneira que ainda é possível sustentar, mesmo utilizando tais índices, que a ciência não oferece verdades ontológicas positivas.

Como tema da investigação ontológica, a ciência é, para Merleau-Ponty, um conjunto particular de procedimentos lingüísticos e técnicos pelos quais os seres humanos estabelecem alguns padrões de contato com o mundo. Entre esses padrões, destacam-se aqueles da busca por infra-estruturas puramente materiais dos fenômenos, as quais são remetidas a leis gerais exprimidas matematicamente. Por meio dessas leis, não só o conhecimento é obtido, mas também a capacidade de intervenção na cadeia causal fenomênica, de maneira a se dominar tecnicamente os eventos em questão. Interessa a Merleau-Ponty, desse ponto de vista, analisar como as pesquisas científicas, que qualificam os sistemas estudados como objetos, erigem-se do ser primordial e se 
tornam possível por meio desse próprio ser. Em O Olho e o Espírito, Merleau-Ponty recomenda que "o pensamento da ciência - pensamento de sobrevôo, pensamento do objeto em geral - volte-se a colocar num 'há prévio' (...), no solo do mundo sensível” (OE, 12). Os procedimentos científicos devem ser analisados como um modo particular de se relacionar com o mundo, modo cuja legitimidade e limite devem ser esclarecidos.

A ausência de reflexão acerca da especificidade lingüística e técnica da ciência gera mistificações sobre a atividade científica, conforme Merleau-Ponty explicita no artigo Einstein e a Crise da Razão. Segundo o filósofo, Einstein dizia que a conformidade entre a inteligência humana e a própria estrutura do real, ou seja, o fato de que os eventos da natureza sejam compreensíveis pelo instrumental científico, é um mistério (Cf. S, 243). A atividade científica ganha, assim, um ar de revelação mística, de acesso mágico a realidades ocultas. O cientista se torna portador de um poder quase sobrenatural de desvendar a verdade, a qual não está ao alcance das pessoas comuns (limitadas às aparências sensíveis). Uma vez que a posição epistemológica einsteiniana não esclarece como a capacidade heurística da ciência decorre de um certo uso especializado da linguagem e da aplicação de métodos de verificação de hipóteses, essa posição fomenta a interpretação pela qual se atribui tal capacidade ao gênio individual dos cientistas. Assim, por vezes, os cientistas são figurados pela opinião pública como taumaturgos capazes de opinar com autoridade mesmo sobre questões que excedem aquelas de seu domínio técnico (Cf. S, 245). Segundo Merleau-Ponty, faz-se necessária uma reflexão acerca do modo como a linguagem e as técnicas científicas se relacionam com o mundo; dessa maneira será possível oferecer uma imagem menos mistificadora da ciência.

Deve-se notar que uma das conseqüências da concepção epistemológica que atribui um caráter quase milagroso ao funcionamento da ciência é reproduzir desprezo objetivista pela experiência sensível. Afinal, o cientista revelaria, segundo tal concepção, verdades que, por se ocultarem para além das aparências sensíveis, não se doam para os comuns mortais. Essa tendência se explicita mais claramente no debate entre Einstein e Bergson acerca da teoria da relatividade. Para Einstein, julga MerleauPonty "é apenas à ciência que se deve perguntar a verdade sobre o tempo como sobre todo o resto" ( $\mathrm{S}, 248)$. A experiência subjetiva do tempo e do próprio mundo pouco ou nada ensina acerca dos componentes da realidade, os quais seriam desvelados pela aplicação da matemática às estruturas do universo. Ora, o problema é que os resultados 
obtidos pela teoria da relatividade destroem as noções comuns de futuro ou passado ${ }^{8}$. Por conseguinte, tal como Bonan exprime de maneira lapidar, "a física se encontra nessa situação paradoxal de só ela ter o privilégio de descrever a realidade e dessa última dar uma imagem incoerente" ". Segundo a perspectiva de Merleau-Ponty, essa consequiência poderia ser minimizada se se explicitasse que os resultados da física decorrem da aplicação de uma linguagem especializada na interpretação de certos fenômenos, e não são, assim, uma revelação direta da realidade última do mundo (Cf. S, 248). Se se apresenta a física como tal revelação, os resultados paradoxais da teoria da relatividade implicam que a aparente coerência da experiência vivida é somente uma ilusão, um véu de hábitos injustificados que recobrem uma verdade absoluta só acessível aos "iniciados" nas técnicas científicas. Por sua vez, se se compreende a física como uma empreitada técnica particular no interior das relações humanas com o mundo, então seus resultados podem ser compreendidos como exploração de possibilidades contidas no mundo sensível. Longe de destruir a pertinência da experiência vivida, tal exploração pode explicitar as complexidades do campo polimorfo apresentado pela percepção, o qual, para Merleau-Ponty (conforme vimos no capítulo anterior), está tão pouco submetido a localizações espaço-temporais unívocas e rígidas quanto os sistemas físicos estudados pela teoria da relatividade.

\section{B) Generalização do método indireto}

\section{Análise de alguns fatos históricos}

Merleau-Ponty não se limita a utilizar a ciência como fonte de dados para sua reflexão indireta acerca do ser. No curso “A filosofia hoje” (1958-1959), ministrado entre o segundo e o terceiro cursos sobre a natureza, o filósofo investiga outros empreendimentos culturais (arte, psicanálise) e mesmo fatos históricos, a fim de obter mais dados para a caracterização do ser primordial. Assim, não só os resultados científicos sugerem uma renovação da ontologia, mas também o movimento da história e da cultura em geral. No curso de 1958-1959, Merleau-Ponty almeja dar "existência oficial" (NC, 37) a um tipo de ser que escapa às categorias tradicionais da filosofia (tais como matéria, espírito, objeto e sujeito), mas com o qual manteríamos contato indireto, "por nossa ciência e nossa vida privada e pública" (Ibid.). Trata-se aqui de reafirmar a

\footnotetext{
8 "Essa razão física abunda em paradoxos, e se destrói, por exemplo, quando ela ensina que meu presente é simultâneo com o futuro de um outro observador bastante afastado de mim, e assim arruína o próprio sentido de futuro" (S, 248).

${ }^{9}$ Bonan, R. Qu'est-ce qu'une Philosophie de la Science? Dijon-Quitigny: CNDT, 1997, p.59.
} 
perspectiva filosófica de renovação das categorias mais gerais pelas quais nos referimos à realidade, perspectiva já assumida desde A Estrutura do Comportamento (conforme apontamos na primeira seção deste capítulo). Porém, em sua fase madura, essa perspectiva não se realiza por um apelo ao campo fenomenal, tal como a Fenomenologia da Percepção propunha, mas pela investigação de diversas áreas da cultura.

Vejamos com mais detalhe o potencial de renovação ontológica contido em três temas históricos, conforme apresentado no curso "A filosofia hoje":

1) Crise na avaliação marxista dos conflitos humanos: Merleau-Ponty busca avaliar criticamente a tese marxista de que a sociedade capitalista é entrecortada por contradições que só seriam superadas por uma revolução comunista. Para tanto, analisa diretamente a obra de Marx. Segundo Merleau-Ponty, Marx ainda se fiaria num princípio clássico de universalidade racional, exprimido na crença em uma sociedade sem divisão de classes. Tal sociedade seria realizada por uma classe social com potencial universalizante, "liberada em potência de todas as contradições" (NC, 40), a saber, o proletariado. Para Merleau-Ponty, essa idéia de uma sociedade sem contradições é abalada por alguns fatos históricos. Nos países em que ocorreu, a revolução comunista, que deveria justamente produzir tal sociedade universalista, instaurou sistemas sociais totalitários, em que a elite militar, repleta de privilégios, reproduzia os vícios sectaristas da sociedade burguesa. Por sua vez, nos países altamente industrializados (onde, conforme a teoria marxista, a revolução, com maior probabilidade, ocorreria), o proletariado passa a defender interesses particulares e se afasta do ideal universalista. Esses fatos impõem a seguinte questão: "saber se há mesmo de direito compossibilidade dos homens - possibilidade de uma sociedade orgânica" (Ibid.). A análise marxista do problema histórico-social humano apontava para uma civilização mundial comunista como solução para os conflitos capitalistas. No entanto, o movimento da história revela o caráter contingente de tal proposta, a qual não conseguiu se firmar. Decorre daí uma crise da compreensão marxista do convívio humano, crise que exige uma renovação conceitual sobre a história e as sociedades humanas.

A análise exposta no parágrafo anterior reflete os resultados da longa meditação política de Merleau-Ponty, a qual, como vemos, também se torna estímulo para a interrogação ontológica. De início, nos anos quarenta, o filósofo defendera um marxismo filtrado pela fenomenologia, o qual ofereceria um estudo concreto da história 
(Cf. PhP, 200). Merleau-Ponty acreditava que o marxismo ampliava significativamente os estudos sobre as instituições sociais ao revelar as relações sobre as quais a coexistência social efetivamente se sustenta. Essas relações seriam de ordem econômica, a qual não deve ser compreendida como uma infra-estrutura separada das demais dimensões da existência humana, mas como um nível das relações humanas em que o caráter exploratório ou emancipador das sociedades se cristaliza de maneira visível. As relações econômicas revelam as estruturas de uma sociedade mais do que sua legislação formal, assim como "se conhece melhor um homem por sua conduta que por seus pensamentos" ( $\mathrm{SnS}, 131)$. Mas o privilégio da ordem econômica no marxismo é interpretado por Merleau-Ponty apenas como um privilégio epistemológico. De modo algum os temas econômicos constituem, nessa interpretação, algum substrato ontológico das sociedades humanas, do qual se poderia deduzir leis necessárias do progresso histórico.

Ainda nos anos quarenta, em Humanismo e Terror, Merleau-Ponty avalia a alternativa prática oferecida pelos marxistas contra os conflitos da sociedade capitalista, a saber, o uso da violência revolucionária, cuja legitimidade seria dada por sua meta: a instauração de uma humanidade livre das contradições sociais (Cf. HT, 205). Merleau-Ponty reconhece o risco de essa violência tornar-se um recurso exageradamente habitual para os comunistas, os quais, em nome da nova humanidade, usariam dela para aniquilar divergências políticas, tal como o filósofo já vislumbrava na sociedade soviética. No entanto, nessa época, o possível fracasso do comunismo soviético não implicava, para Merleau-Ponty, nenhum abalo na doutrina marxista em geral. Afinal, tal comunismo teria sido realizado sem respeitar as condições enunciadas por tal doutrina ${ }^{10}$, de maneira que suas consequiências não serviriam para refutá-la.

Já em textos posteriores de Merleau-Ponty, o fato de que o comunismo real, tal como configurado na Rússia ou China, tenha divergido consideravelmente daquele previsto pela teoria marxista não serve mais de pretexto para isentar essa última das distorções sociais encontradas nesses sistemas políticos empíricos. Na verdade, Merleau-Ponty censura a doutrina marxista por não prever aquele tipo de deturpação feita em seu próprio nome, a saber, a cristalização de um estado intermediário entre a sociedade capitalista e a comunista, em que alguns vícios da primeira persistiam sob a miragem da segunda (Cf. AD, 125, epílogo).

\footnotetext{
${ }^{10}$ A revolução deveria ser organizada pelo proletariado de sociedades altamente industrializadas, cláusula que não pôde ser satisfeita pela Revolução Russa.
} 
Essa negligência do marxismo, avalia Merleau-Ponty no curso "Filosofia e não filosofia a partir de Hegel" (1960-1961), se explicaria por alguns dos pressupostos ontológicos vigentes já na obra de seu inventor, o próprio Marx.. A doutrina do jovem Marx não reduz os seres humanos a substâncias com atributos positivamente determináveis, mas reconhece neles múltiplas possibilidades de se desenvolverem conforme as diferentes relações estabelecidas com a natureza e conforme a instituição de uma história em princípio indeterminada (Cf. NC, 346). Não haveria, assim, uma natureza humana que pudesse ser positivamente descrita. Eis um dos princípios básicos da dialética de Marx: recusa de definições determinadas em favor da descrição de relações opositivas dinâmicas entre os temas estudados. Não seria possível, segundo a dialética, oferecer uma definição tal do ser humano da qual decorresse necessariamente o curso da história, por exemplo. A subjetividade humana e a história se determinam reciprocamente e cabe à reflexão dialética explicitar as cristalizações parciais de ambas e as passagens entre os diversos períodos históricos correlacionados a determinadas formas de subjetivação.

No entanto, Merleau-Ponty julga que as concepções tardias de Marx supõem uma idéia positiva de natureza humana, a qual se realizaria plenamente quando da instauração do comunismo (Cf, NC, 350). Desse modo, a caracterização negativa da subjetividade seria apenas um preâmbulo circunstancial (dada a ausência factual do comunismo) para a verdadeira exposição dos atributos constituintes da natureza humana. A proposta prática de Marx, a revolução, seria o meio para a completa explicitação dessa natureza humana positiva, que subjazeria à negatividade dialética (a qual seria somente efeito das condições materiais capitalistas). Dessa maneira, a concepção tardia de Marx associa a revolução à realização de um estado em que a natureza humana se afirmaria plenamente, e subestima, assim, a imprevisibilidade histórica dos movimentos revolucionários, os quais factualmente tenderam a consolidar Estados totalitários, em que sob a roupagem comunista vigoram as contradições capitalistas.

A fim de sanar a incapacidade marxista de prever esse risco inerente às revoluções (incapacidade fundada em uma concepção ontológica, presente já no próprio Marx, a qual descreve a natureza humana como livre de contradições), Merleau-Ponty já sugeria em Os papéis de Yalta (texto de 1955), que, para ser coerente com seus princípios dialéticos, um marxismo rigoroso não favorece a crença no fim das contradições sociais. Afinal, tal crença supõe aceitar uma noção positiva de natureza 
humana, a qual o próprio método dialético rejeita. No entanto, Merleau-Ponty admite que, com tal mudança, o marxismo "se transforma em outra filosofia" ( $S, 345)$, na qual não é óbvio nem mesmo se o próprio Marx se reconheceria. Em As Aventuras da Dialética, Merleau-Ponty aponta para uma filosofia interrogativa da história, a qual, ao recusar uma descrição direta da suposta natureza humana realizada, exprimiria esse marxismo renovado. Tal filosofia deveria reconhecer o caráter contingente das mudanças históricas e questionar, tal como o curso "A filosofia hoje" explicita, se a condição humana permite uma boa solução para os problemas advindos do convívio social. Esse questionamento contém ressonâncias ontológicas, uma vez que as categorias pelas quais tradicionalmente se compreende a intersubjetividade e as relações com o meio devem ser, por meio dele, renovadas (Cf. AD, 128, 132).

2) Crise nas relações dos seres humanos com a natureza (o micro-mundo): para Merleau-Ponty a distinção entre objeto natural e artefato é embaralhada na ciência contemporânea. No nível subatômico, os fenômenos não são simplesmente verificados, mas produzidos por complexos aparelhos. Revela-se assim uma ambigüidade entre forças naturais e culturais. Tome-se como exemplo a energia atômica transformada em artefato bélico. Essa energia, embora inobservável, compõe o mundo tal como o conhecemos, e poderia mesmo ser usada para destruí-lo (Cf. NC, 42). No entanto, devese considerar que a aniquilação da humanidade por essa energia natural só se torna possível pela domesticação técnica dos seus poderes. Dessa maneira, as forças naturais parecem condicionadas pelos recursos culturais. Para Merleau-Ponty, esse exemplo ilustra a situação geral da ciência física: muitos dos seus objetos não são simplesmente encontrados no mundo, mas derivados das teorias aplicadas. A natureza estudada pelas ciências e apresentada como objetiva é, assim, construída historicamente com a ajuda das técnicas de observação e manipulação disponíveis. Essa ambigüidade, julga Merleau-Ponty, abre a possibilidade de formular uma noção não objetivista de natureza.

3) Crise nas relações entre os seres humanos e a natureza (o macro-mundo): a exploração técnica do espaço sideral abre a possibilidade, ainda remota é verdade, de colonizar outros planetas. A Terra perderia, assim, o privilégio de solo da experiência humana (Cf. NC, 44), já que o desenvolvimento das civilizações humanas na Terra se mostraria um fato contingente, que poderia ser reproduzido em planetas com condições semelhantes. Em contraste com essa relativização da Terra como base necessária para a 
vida humana, Merleau-Ponty considera que o possível acesso técnico a outros planetas e civilizações não abala o caráter central da Terra para a existência humana, mas somente o estende a todos os outros planetas colonizáveis. Haveria assim algo como um estilo terreno de existência que seria levado aos demais planetas (Cf. NC, 45) ${ }^{11}$. No entanto, de maneira geral, Merleau-Ponty reconhece que a exploração técnica do espaço fomenta o questionamento ontológico acerca da pretensa singularidade da vida humana e das possibilidades disponíveis a ela no universo físico.

\section{Análise da arte e da psicanálise}

Não só o movimento histórico e o impacto factual das técnicas científicas sugerem a renovação dos parâmetros ontológicos clássicos. Além desses temas, Merleau-Ponty, em "A filosofia hoje", explora quatro fenômenos culturais, que, por meio de seu caráter intrinsecamente renovador, permitem vislumbrar certos aspectos das relações gerais entre sujeitos e mundo que não são devidamente tratados pelas ontologias clássicas e que fomentam, assim, uma profunda renovação conceitual.

a) Literatura: Merleau-Ponty inicia sua exposição pela poesia contemporânea. Por meio de recursos expressivos aparentados, Mallarmé e Rimbaud ultrapassam a distinção clara entre aspecto subjetivo (a significação) e objetivo (o significado visado) da enunciação. Mallarmé, por exemplo, concebe o significado como circunscrito pelos sons da significação que o enuncia. Assim, as palavras não são mero veículo para se dirigir a objetos autônomos, mas condicionantes do modo como os próprios referentes são determinados. E a poesia, ao jogar com as possibilidades sonoras do idioma em que é produzida, funda uma nova maneira de discriminar os componentes do mundo (Cf. NC, 47). Rimbaud, por sua vez, também teria reconhecido uma unidade primordial entre som e sentido e, dessa maneira, desvelado pela poesia uma camada de experiências que não pode ser adequadamente reconhecida de maneira prévia à sua denominação poética. Desse modo, a compreensão tradicional do sentido (referência a um mundo préordenado) entra em crise ante a experiência poética contemporânea. Porém, alerta Merleau-Ponty, os poetas contemporâneos correm o risco de, em vez de fomentar uma nova compreensão da expressividade lingüística, aprofundarem a crise gerada pelo abalo da concepção clássica de sentido. Buscando romper com o modo tradicional de

\footnotetext{
${ }^{11}$ Merleau-Ponty retoma, assim, a posição defendida por Husserl em Umsturz der kopernikanischen Lehre: die Erde als Urarche bewegt sich nicht. In: M. Farber (org.), Philosophical Essays in Memory of Edmund Husserl, Cambridge: Harvard U.P., 1940.
} 
conceber a referência ao mundo, os poetas podem se limitar à obsessão por invenções léxico-gramaticais, as quais os tornam incapazes de comunicar para além de um restrito círculo de escritores vanguardistas (Cf. NC, 47). Assim, se é verdade que MerleauPonty toma a crise da noção tradicional de sentido como ocasião para uma renovação das categorias ontológicas, o filósofo também avalia lucidamente os riscos que a decomposição das categorias clássicas gera.

Em relação à prosa, Merleau-Ponty nota que os autores contemporâneos romperam com a distinção clássica entre ponto de vista objetivo e subjetivo. Assim, muitos romances do século vinte exprimem uma implicação mútua entre o eu, os outros e o mundo, e, dessa forma, põem em questão a concepção de sujeito como ente separado do meio em que existe (Cf. NC, 48-50).

b) Pintura: segundo Merleau-Ponty, a pintura moderna ${ }^{12}$, assim como a literatura, abala a concepção tradicional de expressividade artística. Os quadros clássicos (século XVI-XVII) eram considerados, por autores e teóricos daquela época, uma representação da realidade, uma imitação daquilo que a percepção normal ofereceria (Cf. NC, 50). Por meio de recursos expressivos tais como a perspectiva planimétrica, muitos artistas clássicos pensavam reconstituir os elementos sensíveis de maneira reconhecível por todo aparelho perceptivo, e, assim, comunicar universalmente o conteúdo representado pelos quadros.

Já os artistas modernos reconhecem que a natureza só pode ser figurada como "produto sedimentado [pela] cultura" (NC, 51), e rejeitam o projeto de uma representação objetiva do mundo. Os recursos expressivos, tais como a perspectiva planimétrica, não são mais concebidos como procedimentos para ordenar os elementos sensíveis como signos universalmente reconhecíveis de uma realidade plenamente determinada. Tais recursos são tomados como técnicas culturalmente desenvolvidas que extraem diferentes aspectos de uma espacialidade polimorfa, cujas possibilidades internas não se esgotam segundo sua representação por uma ou outra técnica em particular. A compreensão moderna da relação entre as linhas pelas quais se desenha e a tela, suporte das linhas, exemplifica a nova concepção de pintura a que Merleau-Ponty se refere. De modo geral, os pintores modernos partem de linhas coloridas como

\footnotetext{
${ }^{12}$ Entendemos por pintura moderna aquela praticada pelo último Cézanne, por Matisse, por Klee e por outros que, como esses, valorizaram os elementos básicos da pintura (linhas, cores, etc), e não apenas seu caráter representativo.
} 
princípio gerador do tema a ser pintado. Essas linhas iniciais funcionam como uma deformação em um campo homogêneo, a qual gera tensões perceptivas, que, para serem solucionadas, exigem que se avance coerentemente na pintura até que se encontre o equilíbrio. Por sua vez, esse equilíbrio final não exprime necessariamente a representação fiel de um referente, mas, antes, a relação das possibilidades perceptivomotoras do pintor com a tela. Não se trata, assim, na pintura contemporânea, de apresentar uma cópia do mundo, mas de compor um mundo-para-si (Cf. NC, 52), ou seja, de tornar as tensões pelas quais a pintura ocorre o tema das próprias pinturas. Por conseguinte, na arte moderna, a explicitação dos referentes escolhidos como temas das pinturas é indireta, já que mediada pela tematização do campo de possibilidades motoras e perceptivas do pintor.

Merleau-Ponty julga que a arte moderna não pretende retratar fielmente uma pretensa realidade objetiva, mas interrogar os elementos pelos quais a própria pintura se faz. Um problema decorrente de sua interpretação é explicar como as pinturas, elaboradas conforme deformações coerentes pelas quais cada artista se relaciona com seu meio, podem comunicar um conteúdo válido para outros sujeitos e almejar um valor universal no sistema da cultura. A interpretação clássica da pintura respondia facilmente ao problema do valor intersubjetivo das obras: cada pintura pretende reproduzir o mundo objetivo, o qual seria percebido de maneira homogênea por todos os sujeitos de constituição psicofísica semelhante. Assim, a pintura bem sucedida apenas reproduziria os signos sensíveis que ativam a capacidade universal de perceber a natureza verdadeira. Porém, no caso da pintura moderna, tal como interpretada por MerleauPonty, as obras não são mais concebidas como reprodução de situações reconhecíveis de imediato por todos os sujeitos, mas como expressão do contato particular do pintor com o mundo. Como o sentido exprimido por tal contato pode ser efetivamente comunicado?

No decorrer de sua obra, Merleau-Ponty oferece respostas diferentes a esse problema. Em “A dúvida de Cézanne”, texto de 1945, o artista é apresentado como alguém que retoma todos os acidentes constitutivos de sua existência empírica e se serve deles como instrumentos para produzir uma obra que exprima o caráter único de sua situação no mundo. A obra de arte é formada, assim, pelos gestos livres de uma subjetividade que tenta ordenar e direcionar os atributos contingentes da sua vida. Não há nenhuma garantia de que o produto de tais esforços, que busca transcender os acidentes da história individual, exceda tal base e seja reconhecido como obra de 
intrínseco valor histórico-cultural. Todas as pinturas portam igualmente a possibilidade de comunicar seu sentido para outros sujeitos. Porém, aquelas que o conseguem dependem da apreciação do público para tanto ${ }^{13}$.

Já no início dos anos cinqüenta, Merleau-Ponty concebe uma nova resposta ao problema da comunicabilidade do sentido artístico ${ }^{14}$. A obra artística não seria mais fruto de gestos motivados somente pela esfera privada da liberdade, pelos quais cada artista, isoladamente, exprimiria sua situação mundana. Em "A linguagem indireta e as vozes do silêncio", texto publicado em 1952, Merleau-Ponty considera que a criação artística, pela qual o sujeito exprime as singularidades da sua existência, encontra-se enraizada em uma universalidade prévia. Ao pintar, o artista parte de sua situação contingente, mas ele o faz segundo as técnicas e os procedimentos sedimentados pelo contexto cultural. Há, assim, um estado geral da cultura que delimita as possibilidades expressivas e mesmo direciona as inovações que podem ser realizadas. Desse modo, a experiência subjetiva da criação revela um vir-a-ser do próprio sentido pictórico e se insere em uma história que em muito a excede ${ }^{15}$.

As obras artísticas, considera Merleau-Ponty em 1952, não são criações contingentes que podem ou não se sedimentar como bens culturais segundo as veleidades dos apreciadores, mas manifestações de possibilidades inseridas no campo cultural previamente partilhado por artistas e espectadores. Assim concebidas, as obras não dependem mais da "complacência do público" (S, 92) para comunicar seu sentido. $\mathrm{O}$ artista explicita e resolve tensões internas ao campo geral da cultura; ao realizar sua obra, ele retoma e faz avançar uma história que forra o seu próprio ato criador. Desse modo, as obras de arte não são resultados contingentes de liberdades isoladas, mas expressão e modificação do estado geral da própria arte, e, dessa maneira comunicam seu sentido e se instauram como patrimônio humano. Ainda que não compreendidas de imediato, as obras se inserem de tal modo no movimento histórico da arte que suscitam seu próprio público. Quer dizer, não que o reconhecimento do público atribua valor universal às criações artísticas, mas essas se impõem de tal forma como retomada e

\footnotetext{
13 "O artista lança sua obra como um homem lançou a primeira palavra, sem saber se ela será outra coisa que um grito, se ela se poderá se destacar do fluxo de vida individual no qual ela nasce e apresentar (...) a existência independente de um sentido identificável" (SnS, 25).

${ }^{14}$ Luiz Damon Moutinho comenta com detalhe essa passagem. Cf. Razão e Experiência - Ensaio sobre Merleau-Ponty. Ed. supra, cap. IX "Pintura e linguagem".

15 "Há uma historicidade de vida (...), aquela que habita o pintor em seu trabalho, quando ele enlaça com um só gesto a tradição que ele retoma e a tradição que ele funda, aquela que o reúne de um só golpe a tudo o que já fora alguma vez pintado no mundo, sem que ele tenha de deixar seu lugar, seu tempo" (S, 79).
} 
transformação da cultura que o público deve reconhecê-las como obras cujo sentido diz algo para todos que partilham daquele contexto sócio-histórico (Cf. S, 92-3).

No curso "A filosofia hoje", já no final dos anos cinqüenta, Merleau-Ponty acrescenta mais um elemento à sua resposta ao problema da comunicabilidade e universalização da arte. Como vimos há alguns parágrafos, o filósofo interpreta a empreitada artística contemporânea não como reprodução do mundo objetivo e sim como explicitação do próprio processo expressivo. Não que a pintura abandone a figuração dos temas mundanos; na verdade, ela os apresenta sem a obsessão da verossimilhança fotográfica. A pintura moderna não almeja mais copiar ou imitar uma pretensa realidade objetiva, mas, avalia o filósofo, "dar a essência" (NC, 54) dos temas figurados. Por "essência", Merleau-Ponty entende as matrizes sensíveis mais gerais pelas quais os temas figurados são reconhecíveis como tais, e não uma fórmula abstrata na qual se registraria os atributos necessários de um tipo de objeto. Por exemplo, com poucas pinceladas coloridas, um pintor apresenta uma pessoa ou uma fruta. Dessa maneira, a essência colorida partilhada por esses temas, anterior às distinções que os classificam como representantes de reinos bem diferentes (o animal e o vegetal), é revelada. Parece que em seus anos finais, Merleau-Ponty defende que uma das razões pelas quais a arte contemporânea comunica seu sentido é a sua capacidade de explicitar as matrizes ou dimensões sensíveis gerais pelas quais, no geral, a experiência é ordenada $^{16}$.

Essa empreitada de explicitação de matrizes sensíveis serve como crivo normativo para guiar a arte contemporânea. Embora não queira "impor nenhum limite à liberdade do pintor" (NC, 54), Merleau-Ponty toma a tarefa de explicitação dessas dimensões sensíveis como o horizonte mais geral ao qual o pintor deveria se referir para ainda comunicar. Para além desse limiar, há o risco de a pintura apenas expor as estruturas ou elementos de que se serve para figurar algo (texturas, relevos, manchas, volumes), mas que em si mesmos nada figuram e são como coisas fechadas em si mesmas. Tal qual ocorria na literatura, a nova concepção de expressividade pictórica pode tanto conduzir a arte para um domínio no qual a relativização dos cânones clássicos permite uma expressão do laço originário com o ser quanto anular toda

\footnotetext{
${ }^{16}$ Nessa explicitação, não se trata de apelar para os elementos sensíveis (cor, forma, etc.) como signos que universalmente desvelariam a realidade objetiva do mundo, tal como, por vezes, a pintura clássica pretendeu. No entanto, a pretensão de apresentar a natureza das coisas aproxima os modernos dos clássicos, embora esses últimos estivessem presos a uma concepção ontológica objetivista, e os primeiros vislumbrem uma noção ampliada de ser, a qual cumpre à filosofia formular.
} 
comunicação efetiva. A fim de evitar essa última possibilidade, a pintura não deveria almejar uma coincidência com os princípios gerais pelos quais as coisas existem independentemente de sua classificação posterior. Essa coincidência anularia a pintura como sistema de significação, pois a reduziria a um caso desses princípios (a um fragmento de superfície com textura, a um conjunto de manchas, etc.). Reduzida a mero exemplo dos elementos pelos quais a figuração ocorre, a pintura deixaria justamente de figurar e não mais revelaria como os entes se constituem pela combinação de tais princípios. Segundo o filósofo, é Paul Klee quem oferece uma "solução" (NC, 55) para o impasse entre a comunicação da arte contemporânea e o rompimento com os cânones representativos clássicos. Klee nunca deixou de se considerar em profunda relação com a natureza à sua volta, a qual ele buscava apresentar em suas telas. $\mathrm{O}$ caráter abstrato de suas obras não romperia o contato com o mundo da experiência cotidiana, mas exprimiria a fibra interna do mundo natural, como que expondo os eixos ou essências sensíveis das quais as coisas e eventos são compostos. Segundo Merleau-Ponty, é por meio da busca dessas essências que a arte contemporânea pode manter algum potencial comunicativo e, além disso, servir à reflexão ontológica.

c) Música: para Merleau-Ponty, a música contemporânea integra as formas tonais privilegiadas historicamente em sistemas atonais mais amplos. Desse modo, revela-se o caráter contingente das normas clássicas de expressão musical, o que, por sua vez, permite que diferentes possibilidades de criação sejam experimentadas. Merleau-Ponty alerta, também no caso da música, para o risco de perda do potencial comunicativo. A excessiva ênfase em colagens de sons sobre os escombros dos sistemas clássicos de significação musical pode retirar da música a possibilidade de veicular algum sentido para além da reprodução, aleatória ou planejada, de ruídos. O filósofo sugere que, para escapar de tal risco, os músicos poderiam buscar os "germes das coisas, e [as] cifras dos sentimentos" (NC, 65, nota), ou seja, usar os recursos expressivos da arte musical para explicitar a unidade pré-lógica de diferentes situações vividas, as quais mostrariam sua proximidade pelo potencial de uma mesma peça musical despertar as ressonâncias de todas elas no ouvinte. Desse modo, os músicos contemporâneos não somente caracterizariam sua arte de maneira negativa, como rompimento com os cânones expressivos clássicos. A liberdade adquirida com as novas possibilidades expressivas seria voltada para tratar de aspectos despercebidos do próprio 
ser, tal como a irmandade sensível de diversas situações tradicionalmente classificadas em categorias distintas.

d) Psicanálise: segundo Merleau-Ponty, a psicanálise, compreendida como um saber terapêutico acerca das relações humanas (Cf. NC, 65), rompe com a concepção clássica de subjetividade. Tal concepção, que vigorou até o início da século $\mathrm{XX}$, se exprime na crença de que a subjetividade se identifica com os atos de posição explícita de sentido ou de fins desejáveis. Com o surgimento da psicanálise, passou-se a considerar que essa atividade autônoma não esgota a amplitude do campo subjetivo. A investigação de sonhos ou de lapsos comportamentais traz à tona processos subjetivos que não são voluntariamente constituídos. E a psicanálise não se limita a reconhecer uma região de passividade no seio da vida subjetiva. Seus estudos pretendem mostrar que mesmo o domínio dos atos volitivos supõe por vezes motivações inconscientes. $\mathrm{O}$ estudo dessas motivações sugere uma noção ampliada de subjetividade, a qual envolveria camadas de representações ou afetos não acessíveis diretamente pela consciência, mas com poder para determinar os atos dessa última.

A psicanálise desintegra a concepção clássica de subjetividade, baseada na idéia de um eu plano em plena posse de si mesmo, e passa a investigar domínios tradicionalmente negligenciados de existências subjetivas, tais como aqueles de comportamentos irracionais, desejos e memórias, domínios que não se submetem às decisões ativas dos sujeitos ${ }^{17}$. Merleau-Ponty considera que tal investigação, em vez de apontar para uma renovação de alguns dos conceitos basilares de nossa cultura (tais como "sujeito", "intenção", "consciência”), pode agravar a crise gerada pela dissolução dos cânones conceituais clássicos. Esse agravamento decorreria de uma certa interpretação da prática psicanalítica: após recensear os principais mecanismos pelos quais as camadas inconscientes influenciam o agir subjetivo, desenvolver-se-ia técnicas de intervenção gerais para desarticular ou minimizar tal influência. Desse modo, julga Merleau-Ponty, a psicanálise reproduz os vícios do objetivismo, pois se dirige para um pretenso objeto autônomo (o inconsciente), o qual seria adequadamente apreendido pelas técnicas terapêuticas. Já vimos no capítulo anterior as sugestões de Merleau-Ponty para a correta compreensão do inconsciente (não como um objeto inobservável, mas como matriz simbólica). Cabe acrescentar agora que, no curso "A filosofia hoje", o

\footnotetext{
${ }^{17} \mathrm{O}$ próprio Merleau-Ponty se enveredou em tal investigação ao explorar a noção de passividade em seu curso de 1954-1955. Cf. capítulo anterior.
} 
filósofo sugere que em vez de delimitar seu campo de ação por imitação das estratégias objetivistas, os psicanalistas deveriam acentuar o potencial de renovação ontológica contido em seus temas. Assim, em vez de constituir uma nova disciplina objetiva, a tematização do inconsciente, da libido e de outros tópicos psicanalíticos deveria propiciar um saber interpretativo das relações inter-humanas não determinado por esquemas prévios extremamente rígidos da vida psíquica e, ao menos parcialmente, fundado por dados empíricos fornecidos pelos resultados clínicos (Cf. NC 149-152).

\section{A ontologia cartesiana da visão}

Como vimos, Merleau-Ponty explicita aspectos semelhantes na arte contemporânea e na psicanálise. Em ambos os casos, o conjunto de definições clássicas que fixava a identidade de um domínio e seus procedimentos práticos (por exemplo, a definição da pintura e de como se pinta, ou da subjetividade e de como ela se comporta) é abalado ante as criações ou teorizações contemporâneas. Tal conjunto se mostra então como contingente, quer dizer, não como modo único de se obter resultados artísticos ou de se compreender a subjetividade, mas como modelos privilegiados durante certa fase histórica. A crise de tais modelos ante os novos sistemas expressivos oferece a ocasião para renovar o entendimento das categorias ontológicas gerais que subjazem a tais modelos, tais como aquelas de sentido ou sujeito. No curso "A ontologia cartesiana e a ontologia de hoje", ministrado em 1960-1961, Merleau-Ponty pretende "formular filosoficamente nossa ontologia que permanece implícita" (NC, 166), quer dizer, pretende sistematizar teoricamente a renovação ontológica que já ocorre nos domínios da arte e da psicanálise, como seu curso anterior evidenciou. Desse modo, é por meio do domínio da não-filosofia, ou seja, de maneira indireta, que a filosofia pode avançar na formulação de uma nova ontologia ${ }^{18}$.

Notemos que no curso de 1960-1961, Merleau-Ponty pretende formular uma ontologia contemporânea "por contraste com a ontologia cartesiana" (NC, 166). Dessa maneira, o filósofo assume que os estudos acerca de autores e temas clássicos são úteis para a compreensão dos problemas atuais. Não que a filosofia contemporânea deva se limitar a tais estudos (de maneira a se tornar história da filosofia). Na verdade, o

\footnotetext{
${ }^{18}$ A expressão "não-filosofia" é ambígua nos textos de Merleau-Ponty. Por vezes, ela indica um estado de crise da filosofia acadêmica, a qual não conseguiria exprimir a complexidade da ontologia contemporânea e se prenderia excessivamente ao estudo de tópicos do passado (Cf. NC, 39; VI, 217, jan. 59). Em outras ocasiões, tal como mencionamos acima, essa expressão indica o conjunto das artes e de disciplinas não filosóficas que implicitamente se desenvolvem sob uma nova concepção de ser, a qual deve ser explicitada pela filosofia.
} 
passado da filosofia deve ser considerado em relação com as circunstâncias presentes, para que assim se instaure um campo geral de interrogação, em que os temas de outrora auxiliem no esclarecimento dos problemas contemporâneos. É o que Merleau-Ponty pretende ao retomar a análise cartesiana da visão, desenvolvida na Dióptrica.

Para explicar a ação da luz na visão, Descartes utiliza o exemplo do bastão pelo qual os cegos reconhecem objetos. Desse modo, a visão é aproximada do tato. Nesse último caso, objetos resistentes se impõem à ação exploratória corporal, a qual deve então reconhecer a existência de algo com que se defrontou. Por sua vez, no caso da visão, os dados captados pelos olhos seriam signos sensíveis a serem posteriormente interpretados como imagens da realidade (Cf. NC, 176-7). Em O Olho e o Espírito, texto escrito concomitantemente ao curso que analisamos e em que o contraste entre análise cartesiana e pintura moderna é explorado, Merleau-Ponty julga que Descartes concebe a visão como "um pensamento que decifra estritamente os signos dados no corpo" (OE, 41). Descartes defenderia que a ação mecânica da luz sobre os olhos, tal como a ação de um bastão sobre objetos, impõe rigidamente sensações que representariam as características do ser exterior. Além disso, Descartes definiria a pintura como reprodução artificial da visão: a tela, bidimensional, imita, por meio de certas técnicas de ilusionismo tais como a perspectiva planimétrica, os conteúdos que a visão obteria caso estivesse diante das coisas representadas nas pinturas (Cf. OE, 44-5).

A explicação cartesiana da visão por meio do modelo do toque é recusada por Merleau-Ponty. Esse modelo despoja a luz "de sua distância, de sua transcendência" (NC, 177), ou, como bem formula $O$ Olho e o Espírito, "da ação à distância e da sua ubiqüidade que fazem toda a dificuldade da visão" (OE, 37). Quer dizer que, para Merleau-Ponty, a visão não se limita a oferecer signos sensíveis positivos que caracterizam diretamente o ser exterior. Na verdade, a visão supõe estruturas complexas tais como a iluminação do ambiente ou a profundidade, as quais não são exatamente dados positivos, embora colaborem de maneira essencial na ordenação do espetáculo visível. Segundo Merleau-Ponty, a teoria cartesiana se restringiu a fornecer uma explicação mecanicista da percepção visual; ela não se dispôs a interrogar as complexidades envolvidas na visão (Cf. NC, 176). Se assim o tivesse feito, talvez Descartes tivesse concluído por uma noção do ser cujos atributos não seriam plenamente atuais e determináveis objetivamente. 


\section{As dimensões invisíveis}

Em contraste com a análise cartesiana da visão, Merleau-Ponty volta a expor, no curso "A ontologia cartesiana e a ontologia de hoje", de 1960-1961, os resultados da pintura moderna (tal como fizera em “A filosofia hoje”). Porém, no curso de 1960-1961, o filósofo acentua de maneira mais substancial as inovações ontológicas implícitas em tal pintura. Na seção intitulada “O pensamento fundamental na arte" (NC, 167-175), por exemplo, Merleau-Ponty retoma uma famosa afirmação de Cézanne como emblema da direção expressiva assumida pela arte moderna: "o que eu tento traduzir-vos é mais misterioso, emaranha-se nas próprias raízes do ser, na fonte impalpável das sensações" (NC, 167). Com essa referência à Cézanne no contexto da obtenção de dados indiretos para a formulação de uma nova ontologia, Merleau-Ponty parece realizar uma sutil autocrítica. O filósofo já havia recorrido às pinturas de Cézanne na Fenomenologia da Percepção, de 1945. Ali, tais pinturas, as quais, segundo o filósofo, pretendiam exprimir mesmo o odor das paisagens retratadas, exemplificavam que a realidade consistia em uma infinidade de relações entre os atributos perceptíveis. Assim, uma paisagem não se comporia somente de elementos visíveis, mas desses últimos entrelaçados a certos elementos audíveis, tangíveis, etc (Cf. PhP, 368, 373). No ensaio "A dúvida de Cézanne", publicado no mesmo ano, Merleau-Ponty caracteriza a pintura de Cézanne como tentativa de captar esse sentido complexo inerente aos fenômenos mundanos, sentido que seria "o berço das coisas" ( $\mathrm{SnS}, 23)$. Deve-se notar que a expressão "berço das coisas" também é usada por Merleau-Ponty para caracterizar o campo fenomenal que teria sido desvelado pela Fenomenologia da Percepção (Cf. PhP, 71). Dessa maneira, nos anos quarenta, a pintura de Cézanne servia a Merleau-Ponty como confirmação das descrições fenomenológicas de um campo de sentido originário, campo por meio do qual se poderia ter acesso aos objetos. Por sua vez, ao retomar Cézanne no início dos anos sessenta, Merleau-Ponty parece sugerir que o escopo de tais descrições ainda era muito limitado e que a compreensão do sentido da obra do pintor exige o desenvolvimento de uma reflexão ontológica, a qual, conforme pretendemos mostrar, excederá em alguns pontos essenciais a doutrina fenomenológica. Essa sugestão estaria contida no comentário que Merleau-Ponty acrescenta à citação do pintor já mencionada acima: Cézanne buscaria "algo que só se oferece através das sensações, mas que está além, na raiz, na fonte, oculto-revelado" (NC, 167). Assim, mais do que explicitar a infinidade de relações constitutivas dos fenômenos, MerleauPonty julga, nos anos sessenta, que a pintura de Cézanne é um exercício para tornar 
visíveis dimensões que transcendem a própria visibilidade. E, no geral, é justamente porque aponta para tais dimensões que a pintura moderna contribui para a reflexão ontológica, como veremos a seguir.

A percepção ingênua acentua aquilo que é percebido. Embora reconheça, conforme expusemos no segundo capítulo, que a ordenação do campo perceptivo é diacrítica (isto é, depende mais da oposição entre dados que da veiculação de um sentido positivo), Merleau-Ponty parece admitir, mesmo em seus textos finais, que a visão profana (tal como se refere à percepção ingênua em $O$ Olho e o Espírito [Cf. $\mathrm{OE}$, 27]) valoriza o espetáculo que se doa. Em O Visível e o Invisível, Merleau-Ponty comenta que há uma visibilidade primeira ou ordinária, que se centra na enumeração das coisas e qualidades positivamente manifestadas. Essa seria a visibilidade apreendida pela percepção ingênua. Além dela, o filósofo afirma haver uma visibilidade segunda, que atentaria para as dimensões gerais que tornam possível tal visibilidade primeira (Cf. VI, 192). Em O Olho e o Espírito e no curso de 1960-1961, fica claro que é a pintura que realiza essa visão em segunda potência, visão que parece não ocorrer espontaneamente na percepção ingênua ${ }^{19}$. Ao pintar o artista moderno não apenas reproduz os temas percebidos, mas repete a própria ordenação das coisas no mundo ${ }^{20}$. Dessa maneira, a pintura explicita aquilo que a percepção ingênua não percebe, aquilo que se mantém invisível para ela (Cf. OE, 27). Eis por que nas reflexões sobre a pintura do final de sua obra, Merleau-Ponty, longe de somente confirmar as descrições fenomenológicas do mundo percebido, esboça uma nova noção do ser. O apelo à arte vem justamente complementar aquilo que uma descrição direta dos conteúdos da percepção ingênua por si mesma não revelaria. A pintura contemporânea mostra não somente o que se doa, mas principalmente as estruturas inaparentes pelas quais a doação sensível ocorre. Uma vez que a pintura rejeita a tarefa de reprodução ou imitação da realidade e passa a exprimir o modo como as possibilidades perceptivomotoras do artista apreendem o mundo (tal como vimos ao analisar o curso "A filosofia hoje"), ela se torna uma empreitada privilegiada para acompanhar a emergência da

\footnotetext{
${ }^{19}$ Não só a pintura excede a visibilidade ingênua. No texto "O metafísico no homem”, de 1947, MerleauPonty defende que algumas teses das ciências humanas (acerca do tema das estruturas) auxiliam a filosofia a superar os limites dos dados fornecidos pela percepção ingênua: "as ciências do homem, em sua orientação presente, são metafísicas ou transnaturais no sentido em que elas nos fazem redescobrir, com a estrutura e a compreensão das estruturas, uma dimensão de ser e um tipo de conhecimento que o homem esquece na atitude que lhe é natural" ( $\mathrm{SnS}, 113)$.

20 "Pintura é segregação do Ser em que primeiramente somos e não construção de 'traços do Ser' que dele dariam a ilusão ou a analogia" (NC, 169).
} 
visão no interior do ser e, no geral, as condições ontológicas pressupostas pelo exercício ingênuo da percepção.

A pintura moderna, assim como os estudos da embriologia (conforme vimos no capítulo anterior), sugere a existência de dimensões (ou princípios de ordenação dos dados) que são invisíveis, mas que costuram a visibilidade, ou seja, que são condições gerais pelas quais a visibilidade é apreendida pelo sujeito perceptivo (Cf. NC, 173). Ao afirmar que tais dimensões são invisíveis, Merleau-Ponty não as concebe como parte de um mundo em-si ou realidade objetiva oculta sob as aparências. As dimensões são os componentes gerais do mundo sensível, aqueles por meio dos quais tal mundo se prepara do seu interior para ser percebido. Porém, ao atuar como dimensões, tais componentes não se doam diretamente. Anuncia-se aqui uma formulação da idéia de sensível como um campo não identificável àquilo que é direta ou imediatamente perceptível. No artigo "O filósofo e sua sombra", de 1959, Merleau-Ponty afirma, ao interpretar Husserl: "o sensível não é somente as coisas, é também tudo o que aí se desenha, mesmo implicitamente, tudo o que aí deixa seu traço, tudo o que aí figura, mesmo a título de desvio [écart] e como uma certa ausência" (S, 217). Dessa acepção larga de sensível fazem parte as dimensões, as quais, embora inaparentes para uma apreensão direta, atuam como condições pelas quais a própria sensibilidade se torna possível $^{21}$.

Uma dessas condições explicitadas pela pintura dos modernos é a profundidade, a qual não é representada como a largura dos objetos vista de perfil. Nas obras modernas, a profundidade não é obtida por recursos ilusionistas, mas, julga MerleauPonty, pela explicitação de um mútuo entrelaçamento entre as coisas, as quais se ocultam parcialmente uma às outras e instituem, assim, uma densidade no campo visual (Cf. OE, 64; NC, 167). A profundidade deriva das relações das coisas entre si; ela é uma condição da visibilidade inerente ao próprio sensível. É porque as coisas estão naturalmente ofuscadas umas pelas outras que a percepção não as apreende de maneira plena e não as reduz a simples correlatos de suas visadas particulares (Cf. VI, 268, nov. 59). Essa afirmação se aproxima de certas fórmulas da Fenomenologia da Percepção, pelas quais se apelava a um excesso fenomenal como garantia da irredutibilidade do mundo a um correlato corporal (Cf. cap. I). Porém, nesse livro, a profundidade era tratada como uma dimensão existencial, ou seja, derivada da relação do sujeito com o

\footnotetext{
${ }^{21}$ Veremos na conclusão as conseqüências dessa ampliação do sensível em relação ao perceptível.
} 
mundo ${ }^{22}$. Já segundo os textos tardios de Merleau-Ponty, mais do que decorrer da relação do sujeito com o meio, a profundidade se organiza no interior do próprio ser. Interessa ao filósofo, nesses textos, acentuar não como a percepção em profundidade ocorre, tal como fazia na Fenomenologia da Percepção, e sim como as condições da percepção em profundidade figuram no próprio mundo que se percebe.

Além da noção ontológica de profundidade, Merleau-Ponty também cita, como exemplo de invisibilidade pela qual o campo visível é sustentado, o imaginário. Longe de definir esse último como reprodução mental de objetos ou situações ausentes, Merleau-Ponty o apresenta como "cifra secreta do real" (NC, 174). Com tal expressão, o filósofo parece sugerir que o imaginário não é só efeito de sensações empíricas, mas também, e principalmente, um arcabouço simbólico pelo qual o real é apreendido (Cf. OE, 23-4). O imaginário não se limita a reativar sensações prévias; ele se antecipa à própria experiência e guia a ordenação dos dados sensíveis ao fornecer matrizes simbólicas sob as quais tais dados são assimilados. Mas não que se trate de uma projeção arbitrária de processos psicológicos sobre os dados empíricos. É verdade que o imaginário acolhe o mundo, como temos acentuado até agora; mas Merleau-Ponty também defende que as matrizes simbólicas do imaginário de algum modo já se encontram no mundo (Cf. NC, 189). Haveria assim, uma circularidade entre imaginário e mundo: o primeiro oferece padrões de ordenação dos dados; mas tais padrões são sugeridos pelo próprio mundo.

Essa ordenação de dados inerente ao próprio mundo por meio de dimensões invisíveis (exemplificadas pelo imaginário e pela profundidade) implica uma nova noção de sentido. Na Fenomenologia da Percepção, "sentido" indicava uma relação em que os dados assimilados pela subjetividade remetem a outros dados que se perfilam paulatinamente conforme a estrutura temporal da experiência ${ }^{23}$. Por sua vez, nos textos finais, "sentido" é a manifestação de conjuntos significativos ou matrizes simbólicas que originalmente estão incrustados no próprio ser, matrizes que o sujeito recolhe como uma inteligibilidade anterior às suas próprias capacidades ativas. O sentido da experiência deixa assim de resultar de uma intencionalidade subjetiva que sempre almeja aquilo que está além do dado atual; ele parece instituir-se a si próprio no interior

\footnotetext{
22 "A profundidade nasce sob meu olhar porque ele procura ver algo" (PhP, 304).

23 "Há sentido para nós quando uma de nossas intenções é preenchida, ou, inversamente, quando uma multiplicidade de fatos ou de signos se presta de nossa parte a uma retomada que os compreende, em todo caso, quando um ou vários termos existem como... representantes ou expressão de outra coisa que eles mesmos" (PhP, 490).
} 
do mundo. Para se aproximar dessa inteligibilidade intrínseca ao ser, Merleau-Ponty apela, na parte final de seu curso "A ontologia cartesiana e a ontologia de hoje" à literatura, como veremos a seguir.

\section{As idéias sensíveis}

Para Merleau-Ponty, o pintor e o escritor contemporâneos exploram o mundo de maneira invertida. O pintor partiria de estruturas elementares do ser (tais como cor, textura, formas) e buscaria explicitar como os objetos e situações retratadas se constituem, em toda sua complexidade, com base na ordenação espontânea desses elementos ontológicos. Por sua vez, o escritor partiria da narrativa de diferentes situações ou fatos complexos e almejaria desvendar certas estruturas elementares pelas quais os temas narrados se ordenam (Cf. NC, 189). Desse modo, a literatura contemporânea buscaria retraçar uma inteligibilidade (inerente ao ser) responsável pela ordenação dos entes visíveis.

Proust é um dos escritores, julga Merleau-Ponty, que melhor teria realizado essa tarefa. O filósofo cita a descrição proustiana, contida no primeiro tomo de Em busca do tempo perdido, da profunda impressão gerada em Swann por uma certa frase musical. Embora não remeta a um equivalente conceitual exato, essa frase musical condensava e veiculava, sempre que ouvida, o amor de Swann por Odette. Não havia um conteúdo preciso que Swann pudesse abstrair da frase musical e apreender como o sentido subjetivo despertado pelo som objetivo. A frase musical expunha nela mesma os sentimentos do personagem, de maneira a servir como molde simbólico por meio do qual tais sentimentos podiam se reordenar em toda sua intensidade ao próprio Swann. Proust não descreve a relação de Swann com a frase musical como associação de experiências (cujo sentido seria previamente articulado) a um "rótulo" musical; na verdade, é a frase que dá forma e acessibilidade às próprias vivências amorosas de Swann. A frase musical funciona, assim, como uma essência ou matriz sensível, a qual, longe de ser constituída pelos poderes da subjetividade, permite que essa organize a sua experiência (Cf. NC, 191-195) ${ }^{24}$.

A descrição proustiana revela, assim crê Merleau-Ponty, o modo peculiar pelo qual a inteligibilidade inerente ao ser atua. Certos entes, assim como a frase musical,

\footnotetext{
${ }^{24}$ Tal como Merleau-Ponty afirma em $O$ Visível e o Invisível, "as idéias musicais ou sensíveis, precisamente porque elas são negatividade ou ausência circunscrita, nós não as possuímos, elas nos possuem" (VI, 196).
} 
não se reduzem a uma existência isolada em uma determinada localização espaçotemporal; eles funcionam como idéias ou essências, no sentido de fornecerem os padrões mais gerais pelos quais uma multiplicidade de fenômenos (no caso, os sentimentos de Swann por Odette) poderia ser reconhecida como tal. Essas idéias não são abstrações que registrariam as propriedades partilhadas por uma classe de indivíduos. Merleau-Ponty as descreve como membrana pela qual o campo da experiência se ordena (Cf. NC, 195), quer dizer, elas não são construções subjetivas, e sim expressões de uma capacidade de agregar eventos inerentes ao próprio ser, assim como as dimensões atuantes no próprio mundo (e que a pintura desvela) preparavam a visibilidade $^{25}$.

Cumpre questionar aqui se há uma diferença entre o tema das dimensões invisíveis, apresentadas pela pintura, e aquele das essências ou idéias sensíveis, tais como a frase musical descrita por Proust. Afinal, a frase musical seria imediatamente perceptível; por sua vez as dimensões do campo visível geralmente não são apreendidas pela percepção ingênua. A fỉm de minimizar essa discrepância, acentuemos que o desvelamento de tais idéias sensíveis ocorre pela literatura, ou seja, envolve criação artística. Assim, a ordenação difusa da experiência por eixos sensíveis gerais só se torna clara por meio da narrativa literária. Sem esse trabalho de expressão lingüística, a função de tais eixos não seria imediatamente apreensível. Quer dizer que embora muitas das essências reveladas pela literatura sejam sensíveis e não dimensões invisíveis, as primeiras, tais como essas últimas, não são acessíveis diretamente à percepção ingênua, e exigem, para se fixar, a retomada expressiva propiciada pela arte, de modo que ambas só podem ser estudadas pela filosofia de modo indireto.

\footnotetext{
${ }^{25}$ Mauro Carbone compara as idéias ou essências sensíveis exploradas por Merleau-Ponty com as idéias estéticas de Kant (representações da imaginação que não se submetem adequadamente a nenhum dos conceitos pelos quais o entendimento ordena a experiência sensível, e que, por isso mesmo, podem apresentar indiretamente o suprasensível) (Cf. Carbone, M. Il Sensibile e l'Eccedente. Mondo estetico, arte, pensiero. Milano: Guerini Studio, 1996, p.109-110). Porém, notamos que, para Kant, as idéias estéticas aparecem como excedente em relação ao mundo perceptível porque o filósofo alemão supõe que toda experiência sensível é ordenada conforme as categorias puras do entendimento humano. Essa suposição não é partilhada por Merleau-Ponty. Assim, mais que descrever as idéias sensíveis como excesso sobre a organização conceitual da experiência, interessa ao filósofo francês apresentá-las como exemplos de uma inteligibilidade inerente ao ser. Essa inteligibilidade figura para Merleau-Ponty como uma condição da própria experiência, condição desconhecida por Kant, para quem toda ordenação interior aos dados provém do entendimento (Cf. Kant, I. Critique of Pure Reason. Transl. by Guyer, P. and Wood, A. W. Cambridge: Cambridge Univ. Press, 1998, p.248, [B, 134-5]).
} 


\section{C) A linguagem filosófica como expressão criadora}

\section{Fixar as estruturas do ser}

Numa nota de Fevereiro de 1959, Merleau-Ponty faz as seguintes afirmações: “não se pode fazer ontologia direta. Meu método 'indireto' (o ser nos entes) é o único conforme o ser" (VI, 231). As análises apresentadas por nós neste capítulo e no anterior pretendem esclarecer as razões pelas quais o filósofo justifica tais asserções. Vimos que sem o apelo ao domínio dos entes (ou seja, aos temas específicos de algumas disciplinas científicas ou de empreitadas artísticas), a concepção geral de ser a que se chegaria seria limitada. Se o filósofo se fiasse apenas nas descrições da experiência ingênua como método para caracterizar o ser (ou seja, definindo diretamente aquilo que existe com base naquilo que se percebe) provavelmente as dimensões negativas, ausentes dos conteúdos percebidos (mas que auxiliam a ordená-los), não seriam consideradas. Tais dimensões se tornam acessíveis seja por meio de teorizações científicas (pensemos no exemplo da totalidade invisível que guia o desenvolvimento do embrião, apresentado no capítulo anterior) seja por meio da expressividade artística (conforme vimos na seção anterior). "O ser é aquilo que exige de nós criação para que dele tenhamos a experiência" (VI, 248, junho 59), assevera Merleau-Ponty em uma famosa nota. Quer dizer que não basta abrir os olhos, ouvir os sons, etc. para apreender a totalidade daquilo que existe, para compreender o modo como as coisas são em sua total complexidade. $\mathrm{O}$ ser depende da inventividade humana para se desvelar, seja por meio de hipóteses científicas pelas quais inúmeros fenômenos podem ser esclarecidos seja por meio de obras artísticas nas quais os eixos inaparentes do mundo sensível são explicitados. Daí que a investigação ontológica não possa se realizar de maneira fecunda sem referência a disciplinas nas quais os aspectos comumente inapreensíveis do ser se revelam sob o exercício da criatividade humana, quer dizer, daí que a ontologia só possa ser desenvolvida adequadamente por um método indireto, que obtém os dados de sua reflexão de disciplinas não filosóficas.

Vamos elucidar com mais detalhes em que consiste essa referência da filosofia ao domínio da não-filosofia. Não é o caso de simplesmente assimilar todos os dados fornecidos pelas disciplinas não-filosóficas. Merleau-Ponty encontra em tais disciplinas alguns índices de uma nova concepção do ser, os quais mais auxiliam na refutação de certas concepções clássicas do ser (por exemplo, a concepção cartesiana, segundo a qual o ser é totalmente positivo e atual) do que oferecem por si mesmos uma ontologia já pronta. $\mathrm{O}$ filósofo não se filia, assim, às doutrinas científicas ou aos estilos artísticos de 
que se serve para sua reflexão. Pelo contrário, Merleau-Ponty sustenta posições críticas em relação a ambos, como resumiremos a seguir.

Quanto aos resultados gerais das ciências, Merleau-Ponty julga que eles padecem de distorções objetivistas. Daí que a referência a tais dados não seja suficiente para a formulação de uma ontologia que pretenda apreender o ser primordial em toda a sua complexidade (como conjunto de dimensões irredutíveis a objetos determinados). Em O Visível e o Invisível, Merleau-Ponty explicita esse ponto: "mostrando o desvio da física e do ser da Physis, da biologia e do ser da vida, trata-se de efetuar a passagem do ser em si, objetivo, ao ser da Lebenswelt" (VI, 218, jan. 59). Assim, é verdade que a biologia, por exemplo, sugere a concepção de um ser que em si mesmo é sensível e entrecortado de dimensões negativas. Porém, trata-se apenas de uma sugestão que a filosofia deve desenvolver por sua conta e risco, pois, em suas conclusões gerais, a ciência define o ser, assim crê Merleau-Ponty, como objeto em-si, alheio às estruturas subjetivas (de maneira a rejeitar aquilo de mais inovador que havia em suas sugestões). Cabe à filosofia explorar as características do ser da vida para além daquilo que pode ser teorizado de maneira objetiva.

Vimos na última seção que Merleau-Ponty também sustenta uma posição crítica relação à arte. Embora tenha revelado dimensões ontológicas comumente imperceptíveis, a arte moderna, dada sua tendência de romper com todas as convenções e procedimentos técnicos, pode produzir obras que já nada exprimem e se mimetizam com coisas e ruídos do mundo. Não se trata, dessa maneira, para Merleau-Ponty, de aprovar entusiasticamente todo vanguardismo, mas de notar que por meio do trabalho de certos autores ou artistas, algumas relações inaparentes com o ser se tornam visíveis $^{26}$.

Diante dos índices fornecidos pelas disciplinas não-filosóficas, as quais se voltam para os entes do mundo (por exemplo, os entes vivos, estudados pela biologia; os entes visíveis, interrogados pela pintura), a filosofia deve, julga Merleau-Ponty, formular uma concepção de ser que escape das limitações teóricas encontradas em tais disciplinas. Nesse ponto, ao tentar exprimir as características do ser para além daquilo que foi vislumbrado nos estudos dos entes, a escrita filosófica deve exercer uma função criadora análoga àquela da literatura. Conforme já havíamos visto em nosso segundo

\footnotetext{
${ }^{26}$ Acentuamos que Merleau-Ponty não propõe critérios normativos que limitem a liberdade artística. Assim, de seu ponto de vista, não há nenhum problema estético com o projeto de uma arte que queira deixar de ser arte e se igualar às coisas mundanas ou aos utensílios cotidianos. O filósofo apenas defende que na formulação de uma reflexão ontológica esse tipo de arte pouco auxiliaria.
} 
capítulo e na seção anterior deste capítulo, Merleau-Ponty concebe a relação entre linguagem e experiência como de fixação da última pela primeira, o que se torna patente na literatura. Sem dúvida, as estruturas ontológicas da experiência possibilitam a ordenação da vivência subjetiva, tal como o exemplo da frase musical narrada por Proust ilustra. No entanto, a explicitação de tais estruturas só se torna possível pela linguagem, a qual as apresenta de maneira publicamente acessível e lhes atribui uma forma resistente para além dos instantes em que efetivamente atuam. Lembremos que as virtudes da frase musical em relação à subjetividade de Swann foram narradas por Proust. Só por meio de tal narrativa literária a própria noção de idéia sensível recebe seus contornos gerais. De maneira análoga à literatura, a escrita filosófica deve exibir as estruturas ontológicas, que são anteriores e condicionantes da própria linguagem. Em uma nota de $O$ Visível e o Invisível, Merleau-Ponty nos assegura: "a verdade é que o quale parece opaco, indizível, assim como a vida não inspira nada ao homem que não é escritor. O sensível é, ao contrário, assim como a vida, tesouro sempre repleto de coisas a dizer para aquele que é filósofo (quer dizer, escritor)" (VI, 300, maio 60). Assim, é preciso escrever, ou seja, fixar e exprimir um sentido que não é imediatamente óbvio, para que a experiência revele seus segredos. É desse modo que Merleau-Ponty pretende desenvolver sua filosofia final: não se trata somente de coletar dados de outras disciplinas, mas também de investigar por si só o ser do mundo; porém, tal investigação não se realiza como simples tradução de experiências pré-ordenadas, mas sob o modelo da expressão criadora extraído da literatura.

Notemos que uma certa concepção do trabalho filosófico como esforço criador já se encontra na Fenomenologia da Percepção. Merleau-Ponty afirma ali que "o mundo fenomenológico não é a explicitação de um ser prévio, mas a fundação do ser; a filosofia não é o reflexo de uma verdade prévia mas, assim como a arte, é a realização de uma verdade" (PhP, XV). Não é fácil compreender qual a tese veiculada por esse trecho. O que significa afirmar que a filosofia não se refere a um ser prévio, mas funda o próprio ser que investiga? A comparação com a arte pretende esclarecer esse caráter fundante da filosofia: as obras artísticas não imitariam ou reproduziriam uma realidade delas independente, mas realizariam uma verdade, quer dizer, explicitariam certos arranjos de elementos sensíveis que só surgem com tal configuração nas próprias obras, e que assim são tornados possíveis pelo trabalho expressivo. Em que medida essa capacidade artística permite formular uma analogia que elucida a investigação filosófica? Deveríamos supor que as situações descritas pela filosofia fenomenológica 
só surgem por tais descrições e, assim, são fundadas pela reflexão filosófica? Ora, se assim fosse, então a filosofia portaria um poder de ordenar o próprio mundo, e não mais faria sentido admitir que ela supõe a experiência irrefletida em sua base, como tantas vezes Merleau-Ponty insiste (Cf. PhP, IX, 74).

Em seus anos finais, como vimos nos parágrafos anteriores, Merleau-Ponty desenvolve uma concepção mais clara da filosofia como expressão criadora. Não se trata mais de sustentar que a filosofia funda o próprio ser, pois se reconhece que há estruturas ontológicas (as dimensões invisíveis, por exemplo) que ordenam a experiência independentemente das capacidades subjetivas. Cumpre à reflexão filosófica não simplesmente fundar o ser, mas explicitar expressivamente e fixar numa forma culturalmente partilhável uma ordenação de sentido que se deve ao próprio mundo.

\section{Crítica à ontologia direta}

A tarefa filosófica de expressão criadora do mundo sensível não está limitada a narrar os objetos apreendidos pela experiência perceptiva ingênua. No geral, a filosofia não está circunscrita aos conteúdos da percepção ordinária, pois tenta explicitar aquelas dimensões invisíveis pelas quais essa própria percepção ocorre. No entanto, a independência em relação ao lastro perceptível não implica uma absoluta liberdade para o filosofar. A linguagem filosófica deve criar formas pelas quais as articulações do ser se revelam, mas não que toda expressão filosófica necessariamente o consiga. Assim como reconhecia limitações nas empreitadas científica e artística, Merleau-Ponty também alerta para alguns riscos da atividade filosófica. $\mathrm{O}$ maior deles parece ser a excessiva crença nas capacidades divinatórias da linguagem. Segundo Merleau-Ponty, "é perigoso dar toda liberdade ao filósofo. Fiando-se muito rapidamente na linguagem, ele seria vítima da ilusão de um tesouro incondicionado de sabedoria absoluta" (N, 122). Assim, o fato de que ao filósofo cabe realizar a expressão criadora não implica atribuir um poder incondicional à linguagem filosófica, como se o que quer que fosse afirmado revelasse inexoravelmente estruturas do mundo. Sem a necessidade de verificar imediatamente suas afirmações pelos dados da experiência (já que se admite que as estruturas do ser por vezes excedem tais dados), o filósofo corre o risco, assim julga Merleau-Ponty, de acreditar que o discurso filosófico se autovalida independentemente de qualquer lastro sensível. 
Merleau-Ponty ilustra essa crença excessiva no privilégio e autonomia do discurso filosófico com o exemplo de Heidegger. Para o filósofo francês, Heidegger teria defendido, seja nos textos iniciais seja nos finais, que o discurso filosófico possui uma capacidade intrínseca de revelar as estruturas ontológicas do mundo, sem depender dos demais saberes humanos. Merleau-Ponty avalia a fase inicial de Heidegger em seu curso "As ciências do homem e a fenomenologia", de 1951. Segundo esse curso, Heidegger (em Ser e Tempo), ao caracterizar o Dasein humano como intrinsecamente envolto pelas situações mundanas, admite uma multiplicidade de formas de se dirigir pratico-cognitivamente ao mundo, formas que se entrelaçam em diversas empreitadas, sem que nenhuma delas seja ontologicamente privilegiada. No entanto, ao apresentar a filosofia, Heidegger atribui a ela a capacidade de elucidar o mundo independentemente de qualquer atividade científica ${ }^{27}$. Assim, na reflexão heideggeriana, "as ciências do homem são pura e simplesmente subordinadas à filosofia" (PPE, 422), a qual não só admite nenhum critério externo para balizar suas teses, mas também parece exercer o papel de saber fundante de todos os demais.

Em sua fase final, Heidegger ainda manteria o excessivo privilégio do discurso filosófico, avalia Merleau-Ponty no curso "A filosofia hoje". Em textos maduros, Heidegger desenvolveria uma tese já presente em Ser e Tempo, segundo a qual não é possível referir-se ao ser como aos entes mundanos, já que o ser não é algo que possa ser circunscrito como um objeto do discurso lingüístico. No entanto, Heidegger teria reconhecido o seguinte nesses textos finais: o fato de que a linguagem existe indica que ela é habitada pelo ser, que a sustenta enquanto tal. A linguagem manifesta, assim, o próprio ser; esse não pode ser referido pela linguagem, mas se explicita no próprio referir-se, na própria atividade lingüística. Caberia então encontrar um tipo de uso da linguagem que acentue esse próprio manifestar do ser pelas palavras. O modo como Heidegger concebe a reflexão filosófica em sua última fase, como um pensar que atende ao chamado do ser, seria essa fala em que o próprio ser se explicitaria. Dessa maneira, julga Merleau-Ponty, Heidegger almejaria “uma expressão direta do Ser” (NC, 148), quer dizer, uma explicitação de estruturas ontológicas que ocorreria apenas porque se usa a linguagem de um modo específico ${ }^{28}$.

\footnotetext{
${ }^{27}$ Cf. Heidegger, M. Sein und Zeit. Tübingen: Max Niemeyer, 2002, §10-11.

${ }^{28}$ É verdade que em seus textos finais Merleau-Ponty se apropria de alguns recursos terminológicos de Heidegger (como o uso de Ser com maiúscula em muitas passagens) e de alguns temas do filósofo alemão (cf. nota 18 da conclusão). No entanto, parece-nos que as críticas dirigidas explicitamente ao filósofo alemão indicam que Merleau-Ponty jamais se filiou estritamente à filosofia heideggeriana.
} 
Merleau-Ponty recusa que a expressão filosófica possua o privilégio de desvelar as estruturas do mundo independentemente dos dados de quaisquer outras disciplinas teóricas ou artísticas. Aceitar esse privilégio implicaria uma ontologia direta, ou seja, uma caracterização do ser limitada àquelas características que o filósofo tem acesso imediato, seja por sua experiência perceptiva seja por seu discurso. Por sua vez, Merleau-Ponty defende que somente um método indireto se conforma às estruturas do ser, já que essas não se limitam àquilo que é diretamente apreensível pelos filósofos. É preciso apelar para os diversos estudos dos entes (empreitadas científicas ou artísticas) a fim de que dimensões inaparentes do mundo sejam explicitadas. A expressão filosófica não possui, assim, um poder inerente de revelar o ser em quaisquer de suas afirmações. Muitas dessas afirmações podem somente comunicar, sob um sofisticado aparato conceitual, idiossincrasias sem nenhuma justificativa na natureza das coisas. O critério que permite distinguir entre uma expressão filosófica que verdadeiramente expõe estruturas do mundo e outra que somente veicula teses injustificadas é exatamente a atenção dispensada aos índices fornecidos pelas disciplinas não-filosóficas. A filosofia não produz fatos novos e não possui temas exclusivos $^{29}$; sua função, enquanto investigação ontológica é ordenar os fatos conhecidos de modo a fornecer uma concepção geral daquilo que existe. Mas os fatos a serem ordenados devem ser coletados de outras disciplinas. Assim, o caráter indireto pelo qual Merleau-Ponty julga que ontologia deve se realizar implica que a filosofia em geral não avança sozinha em sua tarefa, e que embora não se reduza a um mero comentário de doutrinas científicas ou de estilos artísticos, serve-se desses últimos para obter os contornos gerais daquilo que pretende descrever.

A ontologia almejada por Merleau-Ponty só pode progredir por meio dos dados fornecidos pelas demais disciplinas. Mas que dizer dos dados diretos, isto é, das descrições fenomenológicas de experiências perceptivas publicamente acessíveis? Parece que, no decorrer de sua obra, Merleau-Ponty tende para uma maior independência em relação a tais descrições. As teses da sua ontologia final, tais como aquelas sobre o caráter dimensional invisível do ser, não se enraízam nos conteúdos de tais descrições fenomenológicas. A fim de esclarecer esse tema, no próximo capítulo,

\footnotetext{
${ }^{29}$ Em "O filósofo e a sociologia", texto de 1951, Merleau-Ponty defende: "a filosofia não se define por um certo domínio que lhe seja próprio: ela não fala, como a sociologia, senão do mundo, dos homens e do espírito" (S, 138).
} 
avaliaremos detidamente em que medida Merleau-Ponty se afasta da reflexão fenomenológica. 


\section{Capítulo V - Merleau-Ponty intérprete da fenomenologia}

\section{Sinopse}

Inicialmente, explicitamos como Merleau-Ponty, nos anos quarenta, se apropria de temas e procedimentos fenomenológicos conforme seu projeto de explorar a significação filosófica da percepção. Em seguida, acompanhamos como, nos anos cinqüenta, os recursos fenomenológicos auxiliam o projeto de conceber uma noção de ser que não se reduza à manifestação subjetiva, projeto que leva Merleau-Ponty a reconhecer algumas limitações presentes na fenomenologia.

\section{A) O projeto fenomenológico de Merleau-Ponty}

\section{Apresentação}

Vimos, no capítulo anterior, que ao apresentar o método indireto como o único conforme o ser, Merleau-Ponty, em seus anos finais, parece dispensar os dados obtidos pelas descrições fenomenológicas das vivências subjetivas. Para avaliar tal impressão e, desse modo, esclarecer como o filósofo desenvolve sua última ontologia, propomos, neste capítulo, expor como se tecem, de um modo geral, suas relações com a escola fenomenológica.

É preciso afastar, de início, duas simplificações empobrecedoras das relações entre Merleau-Ponty e a fenomenologia. Primeiramente, tais relações não devem ser reduzidas àquelas entre Merleau-Ponty e Husserl. É verdade que o filósofo alemão, fundador do movimento fenomenológico contemporâneo, será o centro das reflexões de Merleau-Ponty sobre o tema; em contrapartida, o interesse do filósofo francês não se limita à obra husserliana, mas abarca os trabalhos de Fink, Gurwitsch, Scheler e Conrad-Martius, autores cuja contribuição para seu pensamento não pode ser negligenciada. Em segundo lugar, deve-se recusar a interpretação segundo a qual haveria um primeiro estágio em que Merleau-Ponty se filia irrestritamente à fenomenologia, e um segundo estágio no qual ocorreria uma ruptura inexorável. Quanto a esse ponto, Jacques Taminiaux observa com razão que não encontramos em MerleauPonty "uma obediência filial a esse ponto de vista da consciência que deveria definir a fenomenologia"1, ponto de vista tantas vezes reiterado pelas análises husserlianas do ego transcendental absoluto. Merleau-Ponty se serve do instrumental fenomenológico

\footnotetext{
1 Taminiaux, J. "La phénoménologie dans le dernier ouvrage de Merleau-Ponty". In : Le Regard et l'Excédent. La Haye : Martinus Nijhoff, 1977, p.73.
} 
para desenvolver uma análise da percepção, concebida como experiência irrefletida, anterior às atividades de uma consciência cognoscente. Assim, deve-se acentuar que Merleau-Ponty inicia sua carreira filosófica com um projeto filosófico próprio, o qual guia a leitura dos textos de Husserl e o leva a formular, na Fenomenologia da Percepção, uma noção ampliada de fenomenologia. Explicitemos a seguir esse ponto.

\section{O estudo da percepção}

Merleau-Ponty escreve dois projetos de trabalho, prévios à sua inscrição formal no doutoramento. No primeiro deles, de 1933, por meio de uma contraposição dos dados experimentais da Gestalttheorie às posições criticistas, o filósofo sugere que o conteúdo significativo dos dados sensíveis não se reduz às relações cognitivas ali projetadas, e conclui que as operações perceptivas não são atividades intelectuais e que devem, por isso mesmo, ser estudadas em sua especificidade (Cf. PP, 12). No segundo projeto, de 1934, a fenomenologia é mencionada como alternativa ao neokantismo e como inspiradora das análises psicológicas da Gestalttheorie, as quais tentariam circunscrever o caráter específico da percepção (Cf. PP, 23). Maria Luz Pintos Peñaranda sugere três fatos que podem esclarecer o interesse despertado em MerleauPonty pela fenomenologia de um ano para outro: Sartre vai à Alemanha em 1933-4 e em seu regresso deve ter entusiasmado Merleau-Ponty com informações acerca dessa escola; Merleau-Ponty conhece pessoalmente Aron Gurwitsch, importante fenomenólogo recém-chegado à França, e assiste aos seus cursos; Merleau-Ponty lê o famoso artigo de Eugen Fink, assistente de Husserl, publicado em 1933 em Kant Studien ("Die phänomenologische Philosophie Edmund Husserls in der gegenwärtigen Kritik") ${ }^{2}$. Ao menos esses dois últimos fatos tiveram impacto certo sobre o filósofo francês. Em seu segundo projeto, Merleau-Ponty realmente se serve do artigo de Fink para afirmar que a fenomenologia "dá ocasião a uma teoria do conhecimento absolutamente distinta daquela do criticismo" (PP, 21). Além disso, Merleau-Ponty cita a tese de Gurwitsch (Phänomenologie der Thematik und des reinen Ich. Studien über Beziehungen von Gestalttheorie und Phänomenologie) como exemplo das contribuições da fenomenologia a problemas da psicologia.

É notável que um dos objetivos de Gurwitsch em seu trabalho é "desenvolver certos problemas fenomenológicos com a ajuda das teses teóricas da Gestalt, assim

\footnotetext{
${ }^{2}$ Cf. Pintos Peñaranda, M. L. "Gurwitsch, Goldstein, Merleau-Ponty. Analyse d'une étroite relation". In: Chiasmi International, n.6, 2004, p.147-171.
} 
como corrigir alguns de seus princípios e, em geral, fazer avançar a fenomenologia ao longo dessas linhas mais além do estado alcançado pelas Ideen de Husserl"3. Os leitores de Merleau-Ponty facilmente reconhecem nessa citação o movimento argumentativo de A Estrutura do Comportamento e da introdução da Fenomenologia da Percepção, o que parece confirmar a importância dos trabalhos de Gurwitsch na elaboração das análises fenomenológicas do filósofo francês.

Passemos à análise de A Estrutura do Comportamento para expor com mais detalhes qual o sentido de fenomenologia utilizado por essa obra ${ }^{4}$. No terceiro capítulo desse livro, Merleau-Ponty se recusa a separar relações significativas e dados concretos. Essa tese implica a existência de estruturas percebidas cujo sentido seria inerente aos dados, e não fundado pela atividade sintética do sujeito cognitivo. Por conseguinte, a natureza percebida não se reduz ao conjunto de objetos constituídos pelo entendimento, mas se manifesta como diferentes regiões fenomênicas com significação imanente; além disso, a subjetividade deixa de ser concebida como foco de síntese intelectual e passa a ser tomada como campo em que diferentes tipos de consciência (imaginativa, amorosa, reflexiva, etc.) se ordenam. Com o desvelamento dessa multiplicidade de vivências subjetivas, a qual é remetida à obra de Husserl (Cf. SC, 186), Merleau-Ponty esboça uma primeira demarcação da reflexão fenomenológica em relação ao criticismo neokantiano.

Os temas fenomenológicos ganham posição central no quarto capítulo de $A$ Estrutura do Comportamento, o qual se abre com uma descrição da experiência ingênua, ainda não dissecada pelas teorias científicas. Essa experiência não é senão aquela do perspectivismo inerente à percepção, conforme descrito por Husserl: cada percepção oferece apenas alguns perfis por meio dos quais as coisas mesmas se apresentam (Cf. SC, 202). Para Merleau-Ponty, tal experiência repugna as interpretações realistas (segundo as quais os conteúdos percebidos são representações exatas, geradas por ação causal, dos eventos objetivos) pelas quais comumente se tenta explicar a atividade perceptiva. Para que tais interpretações fossem justificadas, seria preciso encontrar equivalentes fisiológicos dos temas percebidos, quer dizer, encontrar

\footnotetext{
${ }^{3}$ Gurwitsch, A. Phenomenology of Thematics and of the Pure Ego: Studies of the Relation between Gestalt Theory and Phenomenology, In: Gurwitsch, A. Studies in Phenomenology and Psychology. Evanston: Northwestern University Press, 1966, p.176.

${ }^{4}$ Vale lembrar que é principalmente a fenomenologia de Husserl a qual será explicitamente discutida nesse livro, já que Gurwitsch não é mencionado nesse texto e o nome de Fink surge raras vezes. Mesmo assim, como veremos, não haverá uma aplicação estrita da metodologia husserliana e sim o desenvolvimento de uma análise que deve muito a esses dois autores.
} 
(nos processos que ordenam a percepção) efeitos pontualmente correspondentes aos estímulos objetivos. Segundo Merleau-Ponty, isso não é possível, pois para que tais estímulos realizem sua função representativa, devem se submeter às leis de ordenação do próprio campo fenomenal (Cf. SC, 207). Dessa maneira, aquilo que se percebe é um campo ordenado segundo regras próprias. Não se trata, sem dúvida, de rejeitar que haja um mundo exterior que motiva a atividade perceptiva; Merleau-Ponty apenas rejeita que a percepção de tal mundo ocorra de maneira causal linear.

A tese da irredutibilidade da percepção a processos causais lineares conduz Merleau-Ponty a uma filosofia inspirada no criticismo kantiano, segundo a qual se deve acentuar que as causas objetivas da percepção (os estímulos sensíveis) supõem a consciência dessas condições (ou seja, supõem o trabalho de organização inerente ao campo fenomenal) (Cf. SC, 213). Nesse momento do capítulo, Merleau-Ponty parece aproximar fenomenologia e criticismo: a fim de caracterizar a análise resultante da assunção da consciência como atividade que subjaz aos processos causais, o autor afirma que a filosofia se torna "uma fenomenologia, quer dizer, um inventário da consciência como meio [milieu] do universo" (SC, 215). Na verdade, longe de assumir o criticismo neokantiano, o filósofo se filia à atitude transcendental, ou seja, a "uma filosofia que trata toda realidade concebível como objeto da consciência” (SC, 217).

É inegável que criticismo e fenomenologia partilham da atitude transcendental e que, nesse sentido, ambos são próximos. A especificidade da fenomenologia começa a despontar quando Merleau-Ponty defende que a atitude transcendental está somente numa relação de homonímia (e não de sinonímia) com o criticismo (Cf. SC, 222-3). Quer dizer que há a possibilidade de atribuir à consciência o papel de meio universal, de "igualar a consciência à experiência inteira" (SC, 240), sem assumir posições criticistas, já que tal atribuição não é sinônima de tais posições. Notemos que, para o criticismo, a consciência nunca se relaciona diretamente com o mundo concreto, mas apenas com os objetos constituídos pela própria atividade cognitiva (Cf. SC, 216). Já a consciência à qual a atitude transcendental assumida por Merleau-Ponty apela não é essa, e sim a perceptiva (Cf. SC, 227), concebida como consciência que se relaciona diretamente com as Gestalten físicas, vitais e humanas. Assim, a consciência é um meio universal não porque todas as coisas se apresentam como significações que ela constitui ativamente, mas porque os dados materiais se organizam espontaneamente em formas para a percepção. 
Os objetos revelados sob a vigência da atitude transcendental assumida por Merleau-Ponty são estruturas concretas com uma significação intrínseca (e não meras representações intelectuais). Essa posição, que sem dúvida afasta o filósofo do criticismo, não o aproximaria do realismo do qual ele pensava já ter se livrado? Afinal, se a consciência está em correlação não com significações por ela constituídas mas com estruturas reais, o que então impede de tomar essas últimas como determinantes da primeira? Para escapar desse risco, deve-se entender que a atitude transcendental potencializa aquele argumento da anterioridade do campo fenomenal em relação aos processos causais físicos ou fisiológicos (conforme veremos no parágrafo seguinte). Essa atitude transcendental referente à experiência concreta derivaria da redução fenomenológica de Husserl (Cf. SC, 236), expediente que, segundo Merleau-Ponty, permite marcar o caráter originário da experiência perceptiva ante as teses realistas.

Merleau-Ponty defende, como vimos há alguns parágrafos, que os estímulos objetivos dependem das regras internas ao campo fenomenal, o qual então é fundante em relação aos processos causais explicativos da percepção. No entanto, o filósofo reconhece que a consciência, por conta de uma tendência natural, trata as estruturas percebidas como objetos em si, anteriores e independentes da sua própria atividade. Ao continuar acriticamente essa teleologia espontânea da percepção, "todas as ciências se colocam em um mundo 'completo' e real sem notar que em relação a esse mundo a experiência perceptiva é constituinte" (SC, 235). Merleau-Ponty recorre à redução fenomenológica justamente para anular essa cristalização teórica do senso comum realista: trata-se de retornar à percepção como experiência originária, na qual a própria idéia de mundo objetivo surge. A fenomenologia é a doutrina que fornece o método para que se priorize a relação entre consciência perceptiva e estruturas concretas em contraposição à idéia de um mundo objetivo tal como delimitado pelo senso comum e pelas abordagens científicas. Essa temática peculiarizará consideravelmente a investigação fenomenológica praticada no segundo livro de Merleau-Ponty, a Fenomenologia da Percepção.

\section{Uma fenomenologia da experiência concreta}

Em A Estrutura do Comportamento, Merleau-Ponty se serve da fenomenologia para superar o pensamento causal e o neokantismo no tratamento da percepção, e para priorizar a experiência concreta das Gestalten. Na Fenomenologia da Percepção, ainda se valendo das teses de Gurwitsch e Fink, o autor se aproxima consideravelmente de 
Husserl, e tenta mostrar que em alguns textos do fundador do movimento fenomenológico já há elementos que sustentam, ao menos em parte, tal prioridade ${ }^{5}$.

É principalmente no prefácio da Fenomenologia da Percepção que MerleauPonty esclarece o que compreende por fenomenologia. Nesse texto, primeiramente, o filósofo distingue entre descrição fenomenológica e explicação científica; em seguida, expõe o sentido da redução fenomenológica; em terceiro, esclarece como as essências fenomenológicas estão fundadas na experiência factual; por fim, apresenta a intencionalidade como ligação pré-reflexiva com o mundo. Concentremo-nos principalmente nos dois primeiros tópicos. No início do prefácio, o autor retoma o caráter originário da experiência perceptiva ante o mundo objetivo estudado pelas ciências (tal como já havia realçado em A Estrutura do Comportamento). A valorização fenomenológica da experiência, preconizada por Husserl, implica "a desaprovação da ciência" (PhP, II), não certamente quanto à correção lógica das teorias ou quanto às suas aplicações técnicas, mas sim quanto à pretensão filosófica de que as teorias científicas, ao explicarem objetivamente os eventos mundanos, apresentam de maneira exaustiva o ser mundano. Merleau-Ponty sustenta que o mundo descrito pela ciência é uma construção tardia sobre a experiência perceptiva ingênua, e que a ambição da fenomenologia é justamente recuperar o ponto de vista de tal experiência (Cf. PhP, III).

A ênfase fenomenológica nessa experiência subjetiva não equivale à assunção de uma postura intelectualista, que apresentaria o mundo como conjunto de significações constituídas pelo sujeito. Conforme vimos ao analisar A Estrutura do Comportamento, a atitude transcendental deve vigorar no nível da atividade perceptiva, a qual está em contato direto com as coisas mundanas. De algum modo, esse resultado já estaria esboçado na última filosofia de Husserl, crê Merleau-Ponty (Cf. SC, 236). No prefácio da Fenomenologia da Percepção, o autor explora essa crença mencionada rapidamente

\footnotetext{
${ }^{5}$ Deve-se considerar que tal aproximação se deveu ao esforço de Merleau-Ponty em consultar muitos textos então inéditos de Husserl. Em 1939, ao visitar os arquivos Husserl em Louvain, o filósofo francês pôde consultar a obra Erfahurg und Urteil, organizado por L. Landgrebe, e as transcrições de Ideen II, Umsturz der kopernikanischer Lehre e da parte final da Krisis. Além disso, em 1942, recebeu de Van Breda, então diretor dos arquivos Husserl, uma cópia de vários manuscritos inéditos de Husserl, incluindo o artigo "Fenomenologia" da décima quarta edição da enciclopédia Britannica, a lista completa dos títulos das seções da Krisis e uma cópia da carta de Husserl a Lévy-Bruhl. Nesse mesmo ano, MerleauPonty menciona em carta a Van Breda ter consultado a VI Meditação Cartesiana, de Fink. Em 1944, várias cópias de textos husserlianos foram confiadas a Tran Duc Thao e Merleau-Ponty, incluindo Meditações Cartesianas, A Idéia da Fenomenologia e manuscritos do grupo C, que tratam principalmente da temporalidade. (Cf. Van Breda, H. L. "Maurice Merleau-Ponty et les archives-Husserl à Louvain". In : Revue de Métaphysique et de Morale, n.o 4, 1962, p.410-430 ; Cf. Toadvine, T. "Merleau-Ponty's reading of Husserl : a chronological overview". In : Toadvine, T.; Embree, L. (ed.). Merleau-Ponty's reading of Husserl. Boston: Kluwer Ac. Publisher, 2002, p. 227-286.).
} 
em A Estrutura do Comportamento. O filósofo francês nota uma tensão entre o projeto inicial de Husserl e suas conseqüências efetivas. Husserl, por meio da redução fenomenológica, pretenderia explicitar a consciência transcendental, a qual constitui o sentido dos fenômenos mundanos (Cf. PhP, V). Porém, o interminável questionamento husserliano acerca da possibilidade da redução indicaria a dificuldade de completar tal meta. Os vários recomeços da redução tentados por Husserl exprimiriam, na verdade, "a impossibilidade de uma redução completa" (PhP, VIII) ${ }^{6}$. Segundo Merleau-Ponty, não é possível explicitar uma consciência que constitui ativamente o sentido das experiências vividas. Se se põe entre parênteses a existência objetiva do mundo, tal como prescreve o método fenomenológico, chega-se a resultados não previstos pelo projeto idealista husserliano $^{7}$. O mundo, por exemplo, longe de se manifestar como conjunto de fenômenos ordenados pelo sujeito cognoscente, brota na percepção como conteúdo não constituído por ela, mas ao qual ela responde (Cf. PhP, VIII). Por conseguinte, a redução fenomenológica em vez de abonar uma perspectiva idealista ${ }^{8}$, fomenta uma investigação do sentido perceptivo, o qual não surge de atos subjetivos e sim da correlação espontânea entre os eventos mundanos e a atividade pré-pessoal do corpo próprio. Essa investigação altera o âmbito da fenomenologia transcendental, uma vez que, desde então, o "verdadeiro transcendental" não será mais "o conjunto de operações constitutivas pelas quais um mundo transparente (...) se instalaria diante de um espectador imparcial, mas a vida ambígua em que se faz a Ursprung das transcendências" (PhP, 418). Quer dizer que o contato entre o corpo e as coisas torna-se o foco pelo qual é possível compreender como a experiência do mundo ganha sentido.

Deve-se notar que a posição final de Merleau-Ponty quanto à Husserl na Fenomenologia da Percepção não é criticar uma empreitada idealista que se contradiz em seus próprios resultados, mas sim enfatizar certas alterações no itinerário teórico do

\footnotetext{
${ }^{6}$ Em 1957, em sua curta intervenção no colóquio filosófico de Royaumont dedicado à obra de Husserl, Merleau-Ponty retoma a mesma tese: "o fato de que [Husserl] tenha pensado na [redução] durante vinte e cinco anos sem interrupção parece indicar que a situação da consciência reduzida não é uma situação clara nem fácil de formular" (Merleau-Ponty, M. Discusion. In: Husserl. Tercer Colóquio Filosófico de Royaumont. Buenos Aires: Paidos, 1968, p.143).

${ }^{7}$ Marilena Chaui formula bem o teor desses resultados: "a intencionalidade enraíza a consciência, em lugar de separá-la do mundo; a redução eidética, na tentativa de captar as essências para além da 'tese natural do mundo', descobria a facticidade irredutível que funda o possível sobre o real; a constituição mergulhava num solo de postulados que desvendam tudo quanto não constituímos" (Chaui, M. Experiência do Pensamento. Ensaios sobre a obra de Merleau-Ponty. São Paulo: Martins Fontes, 2002, p.74).

${ }^{8}$ Para Merleau-Ponty, "o próprio do idealismo é admitir que toda significação é centrífuga, é um ato (...) de Sinn-gebung (...). Compreender é sempre em última análise construir, constituir, operar atualmente a síntese do objeto" (PhP, 490).
} 
filósofo alemão que apontariam para uma análise do mundo concreto, análise que o próprio filósofo francês realiza. Para Merleau-Ponty, Husserl teria partido de um "logicismo" ( $\mathrm{PhP}, 317$, nota), chegaria a uma fase intermediária de forte cunho idealista ("período das Ideen" [PhP, 281, nota]) e passaria a um período final marcado por um tipo de "existencialismo" ( $\mathrm{PhP}, 317$, nota), no qual o filósofo alemão "tomou plenamente consciência do que queria dizer o retorno ao fenômeno e tacitamente rompeu com a filosofia das essências" (PhP, 61, nota). É em relação ao projeto do segundo período que os resultados do terceiro mostrar-se-iam contraditórios. Porém, importa salientar não a incongruência entre os dois períodos, mas a abertura paulatina de novas possibilidades para a investigação fenomenológica.

Merleau-Ponty ameniza na própria Fenomenologia da Percepção a sua divisão tripartite da obra husserliana ${ }^{9}$ e admite, por exemplo, o caráter parcial do rompimento final de Husserl com o idealismo transcendental de sua segunda fase. É verdade que em sua última filosofia Husserl realiza a descrição do mundo da vida (Lebenswelt), quer dizer do conjunto de estruturas concretas que sustentam a vida humana e, por conseguinte, qualquer reflexão filosófica. Porém, o filósofo alemão "acrescenta que, por uma segunda 'redução', as estruturas do mundo vivido devem ser por sua vez recolocadas no fluxo transcendental de uma constituição universal em que todas as obscuridades do mundo seriam esclarecidas" (PhP, 419, nota) ${ }^{10}$. Dessa maneira, Merleau-Ponty não nega que há fortes temas idealistas mesmo nos escritos finais de Husserl. Esse fato, entretanto, apenas acentua o dilema contidos em tais textos: por um lado, se a redução fenomenológica deve revelar a consciência pura como responsável pelo sentido da experiência, então não se vê por que passar pelo mundo vivido em vez de ir diretamente até tal consciência. Por outro, se a redução passa pelo mundo da vida, então ela parece desvelar um sentido que não é ativamente constituído e, assim, atesta a impossibilidade de se realizar completamente. É nessa última direção, apesar das recaídas, que Merleau-Ponty vê o pensamento final de Husserl se mover (Cf. PhP, 419, nota $)^{11}$. Na Fenomenologia da Percepção, o autor, por sua conta e risco, tenta estender

\footnotetext{
${ }^{9}$ Em seus textos tardios, Merleau-Ponty praticamente abandona tal divisão, como veremos.

${ }^{10}$ Merleau-Ponty se refere ao trecho de A Crise das Ciências européias em que o eu é apresentado como centro de toda constituição do sentido (Cf. Husserl, E. Die Krisis der europäischen Wissenschaften und die transzendentale Phänomenologie. Ed. supra, § 55, p.190).

11 Dan Zahavi julga tal interpretação convincente. Segundo ele, "embora Husserl insista que a subjetividade é uma condição de possibilidade para a manifestação [do mundo], ele aparentemente não pensa que ela seja a única, isto é, embora ela possa ser uma condição necessária, ela não é suficiente. Uma vez que Husserl ocasionalmente identifica o não-eu com o mundo (Cf. Husserliana XV, 131, 287; Ms. C2 3a) (...) e mesmo ache necessário falar do mundo como o não-eu transcendental (Cf. Ms. C7 6b),
} 
tal direção e explicitar um sentido inerente aos fenômenos percebidos, o qual seria anterior à atividade constitutiva do sujeito transcendental.

\section{Observações críticas}

Vamos avaliar alguns dos riscos corridos por Merleau-Ponty em sua própria empreitada fenomenológica. Para tanto, vale a pena expor as críticas de Aron Gurwitsch ao filósofo francês contidas em Teoria do Campo da Consciência, seu livro de 1957.

Nesse livro, tal como já fizera em sua tese, Gurwitsch pretende "menos dar uma exposição da fenomenologia que fazer avançar certos problemas fenomenológicos"12. No entanto, o autor não deixa de apresentar com clareza o campo de atuação da fenomenologia. Segundo ele, tal doutrina "não se ocupa dos objetos tais como eles são realmente, mas dos objetos tais como eles aparecem por meio dos atos de consciência" . Não se trata de instaurar uma dualidade entre o objeto em si e sua representação mental; importa assinalar que o que quer que os objetos sejam realmente, eles devem se manifestar à consciência, e que a fenomenologia se interessa somente por essa manifestação. Desse modo, a fenomenologia analisa os objetos no como da sua aparição fenomênica, ou seja, analisa os noemas, as coisas tais como elas se apresentam por meio de atos particulares de consciência (e esses atos são chamados de noeses) ${ }^{14}$.

O noema, por um lado, não é, tal como as sensações, um componente real dos atos perceptivos. Afinal, diferentes atos (os quais envolvem diferentes sensações) podem corresponder a um mesmo noema, tese que Gurwitsch exemplifica com o caso de alguém que, sem mudar de ponto de observação e assim conservando sua orientação em relação aos objetos percebidos, abra e feche os olhos diversas vezes ${ }^{15}$. Por outro lado, como já adiantamos, o noema não se confunde com a coisa percebida, pois é apenas uma das suas manifestações possíveis, a qual está em correlação com um ou com alguns atos perceptivos. E mesmo se se apela a um encadeamento indefinido de noemas, não se pode identificá-los à coisa material, visto que os noemas não são afetados pelas alterações sofridas por essa última. Como acentua Husserl em Idéias I,

\footnotetext{
penso que se é levado a concluir que ele concebe a constituição como um processo envolvendo diferentes constituintes transcendentais entrelaçados: subjetividade e mundo" (Zahavi, D. "Merleau-Ponty on Husserl: a Reappraisal". In : Toadvine, T.; Embree, L. (eds.). Merleau-Ponty's reading of Husserl. Boston: Kluwer Ac. Publisher, 2002, p.13).

${ }^{12}$ Gurwitsch, A. Théorie du Champ de la Conscience. Paris: Desclée de Brouwer, 1957, p.7.

${ }^{13}$ Ibid., p. 151.

${ }^{14}$ Como diz Gurwitsch, "os objetos, quaisquer que sejam, reais ou ideais, só figuram nas análises fenomenológicas na qualidade de noemas e de sistemas de noemas encadeados" (Id., ibid).

${ }^{15}$ Cf. Ibid., p. 145 .
} 
uma árvore real "pode queimar, se reduzir a seus elementos químicos, etc. Mas o sentido - o sentido dessa percepção, o qual pertence necessariamente à sua essência não pode queimar, ele não tem elementos químicos, força ou propriedades naturais"16. Assim, uma coisa material pode ser consumida pelo fogo, mas não os seus noemas (o que Husserl chama ali de sentido da percepção). Esses, conforme afirma Gurwitsch, não são senão a coisa tal como ela "aparece em uma apresentação determinada correspondendo a uma percepção dada" ${ }^{17}$.

Após retomar a exposição de tópicos gerais da fenomenologia por Gurwitsch, acompanhemos sua crítica a Merleau-Ponty. Gurwitsch censura o filósofo francês por ter falhado em "distinguir o aspecto noemático do aspecto noético da percepção, e [falhado] em proceder a uma análise aprofundada do aspecto noemático"18. Qual o motivo que justificaria tal censura? Segundo Gurwitsch, Merleau-Ponty "distingue e mesmo opõe a coisa dada na 'evidência própria' ou 'evidência perceptiva' e a série de aparências ou de aspectos concordantes"19. Ora, para Gurwitsch "em uma orientação estritamente fenomenológica, não há lugar para distinguir a coisa mesma de um grupo sistematicamente encadeado de noemas perceptivos" ${ }^{20}$. Ao fazer tal distinção, MerleauPonty teria incorrido em erro. Lester Embree nos ajuda a entender a posição de Gurwitsch: se Merleau-Ponty tivesse levado a cabo uma análise noemática conseqüente, então ele "teria reconhecido que o objeto inteiro está presente em cada um de seus aspectos ou aparências" ${ }^{21}$, e não teria distinguido entre ambos.

De nossa parte, julgamos haver dois problemas na crítica de Gurwitsch. Em primeiro lugar, não é correto afirmar que Merleau-Ponty distingue entre a coisa e os noemas tal como Gurwitsch, e Embree, avaliam que ocorreu. Desde A Estrutura do Comportamento, Merleau-Ponty admite que uma das principais marcas da percepção, descrita fenomenologicamente, é que a coisa, em sua totalidade, é co-percebida em cada aspecto parcial assimilado (Cf. SC, 201-2). Essa tese continua em vigor na Fenomenologia da Percepção, em que Merleau-Ponty defende que cada aspecto

\footnotetext{
${ }^{16}$ Husserl, E. Ideen zu einer reinen Phänomenologie und phänomenologischen Philosophie I. Hua. III. Haag: Martinus Nijhoff, $1950, \S 89$, p.184

${ }^{17}$ Gurwitsch, A. Op. cit., p. 148 .

${ }^{18}$ Ibid., p. 241.

${ }^{19}$ Ibid., p.239. Gurwitsch parece se referir ao seguinte trecho da Fenomenologia da Percepção: "nós não começamos por conhecer os aspectos perspectivos da coisa; ela não é mediatizada por nossos sentidos, por nossas sensações, por nossas perspectivas, nós vamos diretamente a ela e é secundariamente que nós nos apercebemos dos limites de nosso conhecimento e de nós mesmos como cognoscentes" (PhP, 374).

${ }^{20}$ Ibid., p.241.

21 Embree, L. "Gurwitsch's critique of Merleau-Ponty". In: Journal of the British Society for Phenomenology. Vol. 12, n. 2, 1981, p.155.
} 
percebido de uma coisa remete expressivamente a uma infinidade de outros aspectos, e que, assim, a percepção jamais apreende propriedades isoladas, mas a coisa em toda a sua complexidade ${ }^{22}$. O trecho da Fenomenologia da Percepção a que Gurwitsch parece se referir (cf. nota 19) apenas introduz a passagem da percepção na atitude natural para a atitude fenomenológica, e, de fato, não defende que a coisa percebida é distinta dos noemas pelas quais se apresenta. Dessa maneira, a crítica gurwitschena à MerleauPonty, tal como formulada, não procede.

Em segundo lugar, notamos que o próprio Gurwitsch admitira anteriormente que alguma distinção entre a coisa e seus noemas era necessária. Afinal, "a coisa percebida pode possuir propriedades que não figuram em uma apresentação particular. Assim, certas asserções são verdadeiras no que concerne à coisa enquanto existente real e falsas em relação a um noema perceptivo particular" ${ }^{23}$. Acrescentamos que mesmo em relação a um encadeamento de noemas muitas asserções referentes às coisas não se confirmam: lembremos do exemplo de Husserl, segundo o qual nenhum agrupamento noemático pode pegar fogo. Parece-nos, assim, paradoxal que Gurwitsch tenha acusado MerleauPonty de sustentar uma distinção com a qual, no limite, ele mesmo deve concordar. Não haveria nenhum erro, do ponto de vista da fenomenologia, em não identificar a totalidade dos atributos objetivos de uma coisa à manifestação de seus noemas. Essa diferença entre ambas acentua que a fenomenologia se limita a estudar a aparição ou fenomenalização das coisas e eventos sem pretender, com isso, que tal aparição abarque todas as propriedades do seu ser.

Em nosso primeiro capítulo, argumentamos que Merleau-Ponty incorre no problema oposto àquele apresentado por Gurwitsch: o filósofo francês não teria distinguido adequadamente entre noema e objeto. Vamos reexaminar rapidamente esse problema a fim de tornar patente ao menos uma dificuldade do projeto fenomenológico de Merleau-Ponty. O próprio Gurwitsch fornece elementos para repormos o tópico em questão. Ele nota que, para Merleau-Ponty, “o problema transcendental concerne somente à constituição do mundo objetivo tal como ele é em si mesmo, do 'mundo verdadeiro e exato', sobre a base do mundo pré-científico e pré-objetivo tal como ele

\footnotetext{
${ }^{22}$ Citemos ao menos um exemplo fornecido por Merleau-Ponty: "quando eu olho o abajur posto em minha mesa, eu the atribuo não apenas as propriedades visíveis a partir de meu lugar, mas ainda aquelas que a lareira, as paredes, a mesa podem 'ver', o verso de meu abajur é apenas a face que ele 'mostra' à lareira" (PhP, 82).

${ }^{23}$ Gurwitsch, A. Op. cit., p. 145.
} 
aparece na experiência perceptiva imediata" ${ }^{24}$. O filósofo alemão enfatiza que MerleauPonty "não põe questões transcendentais a propósito da constituição desse mundo préobjetivo" 25 , o qual seria aceito em sua "facticidade última"26. Para Gurwitsch, uma redução fenomenológica "radical" 27 deveria buscar as condições transcendentais do mundo percebido, ou seja, deveria reenviar tal experiência ao sistema noético que a ordena. No entanto, Merleau-Ponty rejeita que tal reenvio possa ser realizado. Vimos que o filósofo francês não admite a passagem a um nível em que a experiência perceptiva seria constituída por atos de consciência. Além disso, ele alarga o âmbito do transcendental ao tomar o contato entre corpo e estruturas concretas percebidas como foco originário do qual a noção de ser objetivo é tardiamente derivada.

Notemos que uma das conseqüências desse alargamento do transcendental é a não discriminação entre coisas percebidas (encadeamento de noemas) e coisas em sua realidade autônoma. Dado que a percepção é tratada em termos de contato direto com as existências, a fenomenologia merleau-pontyana não discerne entre o como da manifestação das coisas e essas coisas em si mesmas, e, por conseguinte, não se dedica somente ao primeiro desses dois termos, tal como recomenda Husserl e Gurwitsch. Não encontramos na Fenomenologia da Percepção uma distinção entre objeto intencional (aquele que se manifesta em correlação com os atos subjetivos) e objeto puro e simples (aquele em sua existência material autônoma). Quando Merleau-Ponty descreve a ordenação do sentido percebido (o qual seria recolhido pelo corpo e não constituído pelo sujeito), ele pretende apresentar um sentido presente nas próprias coisas ${ }^{28}$. Não se trata de descrever relações entre aparências percebidas, relações que poderiam não corresponder ao substrato material das coisas. Para Merleau-Ponty, o sentido que a percepção apreende envolve não só a fenomenalidade das coisas, mas a sua materialidade e, no geral, todo o seu ser. Assim, as propriedades componentes das coisas são exatamente aquelas que se manifestam para a percepção e, conversamente, o manifestar-se das coisas circunscreve aquilo que elas são (Cf. $\mathrm{PhP}, 455)$.

Essa identificação entre manifestação fenomenal e realidade implica que o mundo objetivo (o conjunto dos eventos físico-químicos independentes da subjetividade) é somente uma construção intelectual sobre a experiência perceptiva. As

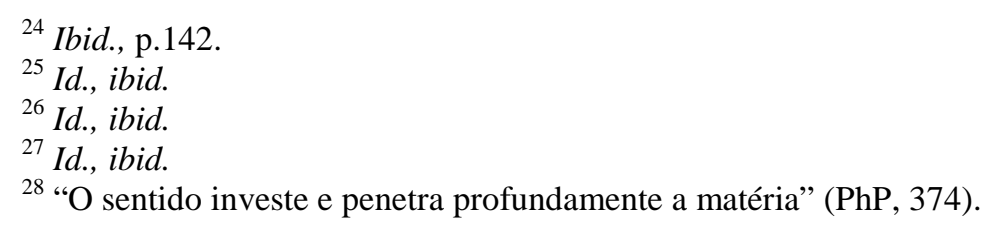


propriedades objetivas formuladas pela ciência seriam especificações de um ser que em si mesmo se confunde com o aparecer fenomenal. Por mais que a ciência insista em que há propriedades mundanas inapreensíveis pela percepção, trata-se somente de abstrações cujo sentido remete àquilo que efetivamente se manifesta $(\mathrm{Cf}$. $\mathrm{PhP}, 71$, 494) ${ }^{29}$. Assim, Merleau-Ponty parece não considerar, nos anos quarenta, que existam propriedades dos objetos que escapem da sua correlação com a subjetividade perceptiva. Afinal, para ele, "a coisa nunca pode ser separada de alguém que a perceba, nunca pode ser efetivamente em si, porque suas articulações expressivas são as mesmas de nossa existência" (PhP, 370). Se essa afirmação se referisse apenas a um domínio noemático (quer dizer, apenas à manifestação das coisas, sem envolver sua existência pura e simples), então a expressividade fenomenal não esgotaria as possibilidades do ser dos objetos. Todavia, uma vez que Merleau-Ponty não distingue entre coisa pura e simples e noemas, é o próprio ser que se delimita pela amplitude perceptiva do corpo, uma tese cujo caráter idealista nem mesmo o Husserl de Idéias I, dada ali a clara distinção entre noema e coisa real, sustentou.

É preciso esclarecer o teor desse caráter idealista presente na obra de MerleauPonty. Em nenhum momento o autor defende algum criacionismo transcendental, segundo o qual a atividade corporal tiraria de si própria o ser do mundo. A atividade perceptiva, tal como descrita pela Fenomenologia da Percepção, é motivada (Cf. PhP, 305), de modo que o corpo apenas responde às solicitações sensíveis e, ao menos numa experiência normal, é dependente dessas últimas. "Jamais minha atitude basta para me fazer ver verdadeiramente o azul ou verdadeiramente tocar uma superfície dura" ( $\mathrm{PhP}$, 248), exemplifica o fenomenólogo. É verdade que o corpo assume uma atitude que determina um sentido vago presente no sensível; porém, essa atitude pressupõe justamente que haja um sentido inerente aos estímulos, de modo que o ser do mundo nunca é reduzido a um conjunto de fenômenos criado pelo corpo.

Mesmo com essa ressalva, a crítica do penúltimo parágrafo se mantém: o mundo, ainda que não seja produzido pelo corpo, se limita ao que é reconhecível em sua correlação atual ou possível com os poderes perceptivos do corpo. Na Fenomenologia da Percepção, Merleau-Ponty não desenvolve a hipótese de um excesso do ser do

\footnotetext{
${ }^{29}$ Vimos no terceiro capítulo que Merleau-Ponty altera consideravelmente sua posição quanto a esse tema nos anos cinquienta. Nos cursos sobre a natureza, os dados científicos inobserváveis são aceitos como índices de um ser primordial que excede os conteúdos apreensíveis pela percepção ingênua.
} 
mundo em relação às atividades intencionais subjetivas ${ }^{30}$, de um invisível irredutível à visibilidade, de uma transcendência que escapa ao campo fenomenal assimilado pelo corpo. A realidade do mundo, na Fenomenologia da Percepção, se confunde com uma infinidade de relações perceptivas, que jamais podem ser abarcadas por uma única experiência corporal. Mas essa impossibilidade decorre apenas da limitação factual do corpo, pois, por princípio, todas essas relações são correlatas dos poderes intencionais subjetivos, os quais portam o projeto de todo ser possível (Cf. PhP, 411). Assim, embora não faça do corpo o demiurgo da realidade, Merleau-Ponty delimita, na Fenomenologia da Percepção, o ser do mundo segundo o que pode aparecer para a existência humana.

Vimos, em nosso primeiro capítulo, que, sob críticas de diferentes autores, Merleau-Ponty reconhece a insuficiência da posição ontológica decorrente de seu projeto fenomenológico e se dedica a aprimorá-la nos anos cinquienta. Vejamos como a fenomenologia figura no novo quadro teórico que o filósofo molda nessa época.

\section{B) Novos dados indiretos para a ontologia}

\section{Fenomenologia e ciências humanas}

Em meados dos anos cinqüenta Merleau-Ponty aborda a fenomenologia à luz de um questionamento explicitamente ontológico. Segundo o artigo "Sobre a Fenomenologia da Linguagem”, de 1951, “o que me é ensinado pela fenomenologia da linguagem não é somente uma curiosidade psicológica" (S, 110). As análises fenomenológicas revelam um poder de expressão inerente à fala, o que implica reconhecer a centralidade do sujeito falante no estudo da língua. E como esse poder é um caso da intencionalidade corporal (Cf. S, 111), a produtividade da fala deve ser remetida ao sujeito encarnado, o qual, como sabemos desde a Fenomenologia da Percepção, está em correlação com o mundo pré-reflexivo. Todos esses temas envolvem uma "concepção do ser" $(S, 118)$ e não se limitam a relatos psicológicos ${ }^{31}$.

Merleau-Ponty sustenta que esse teor ontológico da fenomenologia já se encontra nos textos do próprio Husserl. A fim de comprovar essa tese, o filósofo francês retoma um argumento exposto na Fenomenologia da Percepção: é verdade que Husserl considerava as análises do mundo da vida como meramente preparatórias para a

\footnotetext{
${ }^{30}$ Tal como notamos em nosso primeiro capítulo, Merleau-Ponty chega, ao menos em uma passagem, a considerar essa hipótese (Cf. PhP, 250-1).

${ }^{31}$ Vimos, em nosso primeiro capítulo, que Merleau-Ponty já pretendeu extrair uma concepção de ser das descrições fenomenológicas na Fenomenologia da Percepção.
} 
verdadeira análise transcendental; no entanto, ao se investigar tal mundo, revela-se a vida encarnada, a qual não pode ser absorvida pela consciência transcendental pura (Cf. S, 115-6). Dessa maneira, o projeto idealista husserliano dá ocasião a uma investigação ontológica do mundo percebido.

Merleau-Ponty desenvolve esse tema do rompimento com o idealismo, que direciona até então a sua leitura de Husserl, de maneira a exibir uma aproximação entre os resultados da fenomenologia e aqueles das ciências humanas. Esse é o tópico principal do curso "As ciências do homem e a fenomenologia" (1951). Nesse curso, o filósofo retoma alguns elementos da perspectiva interpretativa assumida na Fenomenologia da Percepção, segundo a qual a problemática husserliana se inicia com tensões entre psicologismo e logicismo, as quais se resolvem por uma redução fenomenológica concebida de maneira idealista (retorno à consciência pura como fonte de todo sentido) (Cf. PPE, 404). Além disso, o filósofo francês também defende que, em sua última fase, Husserl não mais apelaria a uma consciência fundante dos fenômenos, mas buscaria "reencontrar um sujeito já engajado nos fenômenos" (PPE, 405). Desse modo, haveria um rompimento mais ou menos explícito com o idealismo da segunda fase e o reconhecimento da prioridade da experiência concreta em relação às essências pelas quais a estrutura dos fatos seria conhecida.

Essa reabilitação da experiência concreta aproxima a fenomenologia de várias ciências humanas. Merleau-Ponty expõe as relações entre o pensamento de Husserl e a psicologia, a lingüística e a história. $\mathrm{O}$ filósofo francês assevera que, num primeiro momento, Husserl julgaria que por meio de ontologias eidéticas regionais circunscrevem-se as noções fundamentais a que as disciplinas positivas deveriam se dedicar. Por exemplo, para estudar o psiquismo, os psicólogos precisam saber de antemão o que se entende por um fenômeno psíquico, e isso só é possível se se dispõe da essência dessa região em questão, a qual se revelaria para uma intuição eidética (Cf. PPE, 408). Husserl reconheceria desde cedo que essa intuição eidética depende da apreensão de fatos, dos quais se buscam justamente as estruturas gerais. O fenomenólogo alemão teria admitido mais tardiamente que os mesmos fatos também estão disponíveis para a psicologia empírica, a qual os estuda não por meio de variações imaginárias, mas por comparações efetivas propiciadas pelos métodos indutivos. Assim, Husserl não negaria haver um paralelismo geral entre fenomenologia e psicologia empírica, e rejeitaria a estrita fundação da primeira pela segunda (Cf. PPE, 412). Essa progressão do pensamento de Husserl se repetiria na questão da linguagem: o filósofo 
alemão passaria de uma eidética dos modos de significação (a qual revelaria a fonte de toda língua possível) à consideração de um sentido inerente às falas empíricas, o qual a lingüística, à sua maneira, também explicitaria. Tal progressão também seria reconhecível no que concerne ao tema da história: Husserl passaria da busca por uma filosofia fundada numa evidência atemporal para a valorização da sedimentação histórica do sentido filosófico. Assim, de modo geral, haveria um esforço de Husserl para instaurar uma complementaridade entre facticidade e reflexão transcendental, entre as ciências positivas e a filosofia (Cf. PPE, 415-20). Esse esforço seria, segundo Merleau-Ponty, mais radical do que aquele de Scheler, defensor da existência de certas essências eternas (Cf. PPE, 421), e do que aquele de Heidegger, defensor, tal como expusemos no capítulo anterior, da filosofia como um poder irrestrito de exploração do mundo, poder independente de qualquer recurso às ciências humanas (Cf. PPE, 422).

No artigo "O filósofo e a sociologia", publicado em 1951, Merleau-Ponty salienta que um dos méritos de Husserl é ter elaborado um "domínio e uma atitude de pesquisa em que a filosofia e o saber efetivo poderiam se encontrar" (S, 128). Essa aproximação das investigações cientifica e fenomenológica reforça o projeto de renovação ontológica adotado por Merleau-Ponty nos anos cinqüenta. Vimos que em "Sobre a fenomenologia da linguagem" o filósofo defende que aos resultados das descrições fenomenológicas se deve atribuir um teor ontológico. A convergência desses resultados com os temas das ciências humanas ratifica essa conclusão, pois, segundo Merleau-Ponty, certos estudos científicos (que pesquisam as estruturas concretas, conforme o capítulo anterior) sugerem uma renovação ontológica, a qual vai ao encontro das teses fenomenológicas. As pesquisas lingüísticas, por exemplo, revelam "a mediação do objetivo e do subjetivo, do interior e do exterior que a filosofia procura" (PPE, 87). Assim, a explicitação de um ser anterior à cisão entre subjetividade e objetividade estaria prefigurada seja em algumas pesquisas científicas seja em algumas descrições da fenomenologia.

\section{O ser anterior à constituição}

À medida que a investigação ontológica de Merleau-Ponty avança, altera-se seu interesse pela fenomenologia. O filósofo abandona a interpretação segundo a qual haveria três fases distintas na obra de Husserl, e passa a sustentar somente que no decorrer da maturação do pensamento husserliano ocorre uma oscilação entre projeto e resultados. Merleau-Ponty expõe como compreende tal maturação no curso "A filosofia 
hoje" (1958-1959). De início, Husserl pretenderia formular uma filosofia rigorosa e baseada em princípios apodíticos, a qual se contrapõe ao psicologismo e ao historicismo. Para tanto, o filósofo alemão buscaria atingir as essências necessárias dos temas tratados, ou seja, os princípios invariantes pelos quais se pode, por exemplo, reconhecer um fato como pertencente a uma determinada classe de eventos. As essências seriam obtidas por uma redução eidética, quer dizer, pela explicitação das características definidoras dos fatos particulares, aquelas sem as quais eles deixariam de ser o que são. Nas Investigações Lógicas, Husserl não defenderia que tais essências existem de maneira autônoma, mas sim que elas são postas por atos de intuição e vigoram, assim, como correlatas da atividade subjetiva (Cf. NC, 67). Em seguida, no período das Idéias e de Meditações Cartesianas, Husserl estenderia o anti-realismo referente às essências para toda relação com o mundo. Nesse período, com a assunção do idealismo transcendental, o filósofo alemão examinaria de que maneira as intencionalidades subjetivas condicionam não só o acesso às essências dos fatos, mas mesmo aos objetos da percepção, os quais se doam como conjuntos de fenômenos em correlação com atos doadores de sentido (Cf. NC, 68). Husserl se encaminharia, assim, para a explicitação da consciência transcendental, responsável pelo estabelecimento do sentido das experiências vividas. No entanto, tal como já notara na Fenomenologia da Percepção, Merleau-Ponty sustenta que ao investigar a experiência em suas diversas camadas (as quais deveriam ser remetidas ao poder constituinte da consciência), Husserl acabaria por desvelar um sentido sensivel fundante da atividade subjetiva. Mas tal desvelamento é apresentado pelo filósofo francês, nos anos cinqüenta, como um resultado que convive com a perspectiva idealista, e não (tal qual expunha em algumas passagens da Fenomenologia da Percepção) como o advento de uma fase existencialista, em que Husserl encerraria sua carreira.

Importa a Merleau-Ponty, nos anos cinqüenta, tomar esse resultado da filosofia husserliana como índice de uma ontologia a se realizar. Em seu primeiro curso sobre a natureza (1956-1957), por exemplo, conforme tratamos no terceiro capítulo, MerleauPonty expõe como Husserl mostra alguns pressupostos pré-reflexivos da atitude teórica, ou seja, da formulação de conhecimento científico. A noção de coisas objetivas, independentes da subjetividade, supõe, em primeiro lugar, a atividade corporal. O sujeito toma consciência das coisas em correlação com os movimentos do corpo próprio (Cf. N, 108). Em segundo lugar, para que os resultados da percepção não se limitem a fenômenos privados, é preciso considerar o caráter intersubjetivo da experiência. É a 
confirmação de que uma coisa se manifesta publicamente (confirmação que exige o assentimento de vários sujeitos) o que atribui solidez aos temas da experiência individual, inconfundíveis então com aparências meramente particulares (Cf. N, 109). Além disso, Merleau-Ponty nota que, em seus textos finais, Husserl apresenta um terceiro elemento condicionante das idealizações da atitude teórica: um solo ou meio ambiente em que a existência humana se desenvolve. Esse é o tema do manuscrito "A Terra como arca originária não se move", texto que o filósofo francês provavelmente conhecera já em 1939 e que ganha destaque nas reflexões de seus últimos anos de vida. Husserl reconhece, nesse texto, que a Terra não se reduz a um objeto qualquer no universo objetivo, mas é a base que sustenta todo pensamento humano, uma camada concreta que torna possíveis as idealizações criadas pela subjetividade (Cf. N, 110-1).

Merleau-Ponty retoma essas conclusões em seu curso "Husserl nos limites da fenomenologia" (1959-1960), no qual se dedica a traduzir e analisar alguns textos do filósofo alemão, principalmente "A origem da geometria como problema históricointencional", famoso anexo de A Crise das Ciências Européias e a Fenomenologia Transcendental, além de retornar ao manuscrito "A Terra como arca originária não se move". A escolha desses dois textos não é arbitrária. Ao expô-los, Merleau-Ponty pretende mostrar que, seja em relação à superestrutura ideal (no que tange aos objetos geométricos) seja no que concerne à base terrena do ego, Husserl vislumbraria temas que não poderiam ser tratados pela análise constitutiva estrita, pois sua organização significativa não surgiria de atos de consciência. Segundo o filósofo francês, Husserl, em "A origem da geometria", apela para a facticidade da escrita a fim de tornar compreensível a permanência dos objetos geométricos para além da sua descoberta. É preciso que as invenções geométricas sejam registradas materialmente para que se tornem idealidades universalmente disponíveis e independentes dos episódios subjetivos em que foram criadas. Desse modo, a aparente validade atemporal dos objetos geométricos supõe os instrumentos culturais de comunidades humanas localizadas espaço-temporalmente. Por conseguinte, “o mundo ideal [está] apoiado sobre o mundo sensível" (OG, 69), quer dizer, a validade objetiva das significações geométricas decorre de processos de instituição de sentido que envolvem condições factuais. Além disso, nesse mesmo curso, Merleau-Ponty volta a acentuar o estudo husserliano da Terra como base para o pensamento humano. A Terra seria a arca originária, a qual (assim como a arca de Noé salvaguardou a vida em meio ao oceano) assegura toda a possibilidade de existência humana em meio ao universo material (CF. OG, 90). Ao 
investigar a Terra assim concebida, Husserl teria explicitado uma condição sensível para a própria reflexão transcendental.

No artigo "O filósofo e sua sombra", de 1959, Merleau-Ponty continua as reflexões acerca do reconhecimento de camadas pré-reflexivas pela fenomenologia husserliana. Tal reconhecimento não teria ocorrido de maneira explícita; porém, sua presença inegável em alguns textos indica haver um impensado na obra husserliana, quer dizer, um conjunto de teses que excede o quadro teórico no interior do qual o autor conscientemente pretende se mover. Como excesso aos próprios instrumentos teóricos de um autor, o impensado não é obviamente analisado por quem o cria; no entanto, sugere uma direção a ser explorada pelos leitores (Cf. S, 203). Essa direção, no caso de Husserl, é exatamente aquela rumo ao mundo pré-reflexivo, cujo sentido não se reduz àquele constituído pela subjetividade cognoscente. Ao estudar o papel do corpo, da intersubjetividade e da Terra, Husserl teria desvelado tal mundo como "um inverso das coisas que nós não constituímos" (S, 227), mas que alimenta a vida subjetiva.

Esse inverso dos atos constituintes não se confunde nem com o em-si objetivista (já que ela se compõe de significações sensíveis, que se manifestam ao sujeito) nem com as puras representações subjetivas (já que tal sentido justamente não é constituído pelo sujeito) (Cf. S, 209). Nas notas do primeiro curso sobre a natureza tomadas por Xavier Tilliete e publicadas com o título "Husserl e a noção de natureza", o mundo préreflexivo é "um modo de ser original, um ser em estado selvagem" (PII, 229). Trata-se daquilo que é denominado carne do sensível (Cf. S, 211), ou seja, arranjos inerentes ao próprio ser por meio dos quais o mundo se prepara de seu interior para uma apreensão subjetiva (embora não dependa de tal apreensão para se ordenar como tal) ${ }^{32}$.

Ao explicitar tais arranjos, a fenomenologia, que pretendia afirmar o caráter ativo da subjetividade em todas as experiências, termina por exibir uma camada ontológica de que a própria reflexão depende (Cf. NC, 84). Nesse sentido, a fenomenologia, tal como ocorre com as ciências e as artes (cf. Capítulos III e IV), sugere uma investigação ontológica do ser primordial, o qual não se confunde com aquilo que é fruto da atividade subjetiva, sem com isso se identificar a um tipo de em-si incognoscível. Os resultados da empreitada husserliana são, assim, outra fonte de dados indiretos para Merleau-Ponty desenvolver sua ontologia. Por conseguinte, em seus anos finais, mais do que se servir dos conteúdos diretamente fornecidos pelas descrições

\footnotetext{
${ }^{32}$ Analisaremos com mais detalhe essa noção de carne do sensível no próximo capítulo.
} 
fenomenológicas, importa a Merleau-Ponty desenvolver aquilo a que tais descrições apontam como seu limite: um ser que excede o papel de correlato dos atos subjetivos e fornece a base para tais atos.

\section{Os limites da fenomenologia}

Nos anos quarenta, Merleau-Ponty expunha que os resultados não idealistas da fenomenologia husserliana facultavam a exploração da existência encarnada como tema básico de uma análise transcendental renovada, da qual, conforme a seção passada, a Fenomenologia da Percepção seria exemplo. Por sua vez, nos anos cinqüenta, MerleauPonty encontra nesses mesmos resultados uma ocasião para investigar o ser bruto ou primordial, alheio às categorias clássicas. Essa dupla utilização dos temas husserlianos se deve ao fato de que Merleau-Ponty, em ambos os casos, os assimila segundo projetos filosóficos próprios. No primeiro caso, seu projeto era o de extrair conseqüências filosóficas do estudo da percepção tal como conduzido pela Gestalttheorie. No segundo, trata-se de conceber uma noção ampliada de ser, que não se limite à manifestação subjetiva (tal como expusemos nos capítulos anteriores). Assim, as teses husserliana são ora apropriadas no contexto de uma investigação da existência humana ora no contexto de uma investigação do ser primordial ${ }^{33}$.

\footnotetext{
${ }^{33}$ Esse procedimento de apropriação de temas filosóficos à luz de uma problemática própria se repete em relação a Descartes. Em A Estrutura do Comportamento, Merleau-Ponty elogia a radicalidade da intenção filosófica de Descartes: questionar as justificativas do conhecimento baseadas na existência do mundo exterior e investigar a estrutura interna da experiência para aí encontrar a base de todo saber (Cf. SC, 210). No entanto, Descartes não seguiria essa via de maneira satisfatória; a experiência revelada pelas Meditações Metafísicas, por exemplo, é abstrata. Ali, Descartes consideraria somente o pensamento de ver, e ignoraria que o fato da visão envolve um contato com os eventos mundanos (Cf. SC, 212). Para corrigir a perspectiva cartesiana, é preciso investigar não só a atividade subjetiva inerente à percepção, mas também o contato do sujeito com as existências concretas, de maneira a rejeitar uma posição estritamente idealista. Eis a tarefa que Merleau-Ponty pretende cumprir ao elaborar uma fenomenologia da percepção. Já em seus últimos anos, interessa a Merleau-Ponty explicitar a ontologia de Descartes, a fim de contrastá-la com a concepção contemporânea do ser. Merleau-Ponty toma Descartes como "alguém que teve uma certa experiência do Ser exprimido nessa prioridade oficial do conhecimento" (NC, 233), tema que tanto marca a obra do autor clássico. No entanto, Merleau-Ponty crê que, mesmo se privilegia o conhecimento, Descartes entrevê o ser pré-reflexivo, e oferece, assim, sugestões proveitosas para a ontologia contemporânea. Nos primeiros textos de Descartes, tal como Regras para a Direção do Espírito, a presença do pré-reflexivo no seio da esfera epistêmica seria reconhecível pelo uso de metáforas sensíveis para as capacidades cognitivas (tal como luz natural para o entendimento humano), as quais indicariam a prioridade do contato perceptivo com o mundo, contato que se torna modelo da empreitada do conhecimento (Cf. NC, 224-6). E mesmo nos textos tardios de Descartes, como Meditações Metafísicas, em que se criticam entre tantos outros prejuízos os dados recebidos pela percepção, o ser pré-reflexivo ainda seria ali reconhecível. O advento do cogito estaria fundado em uma experiência irrefletida da subjetividade como campo de manifestação de todos os fenômenos possíveis: tudo o que aparece deve se conformar às estruturas da consciência humana. É esse projeto silencioso de todo ser, "essa constatação ou experiência de que eu sou inalienável para mim" (NC, 249), que possibilita a posterior formulação reflexiva do cogito como natureza intelectual inata e universal. Merleau-Ponty conclui, assim, que em ambas as fases da filosofia cartesiana é possível encontrar uma referência
} 
No interior desse último contexto, Merleau-Ponty julga, como vimos na subseção passada, que Husserl teria antevisto o ser primordial anterior às cisões entre propriedades subjetivas e objetivas. Nesta subseção, vamos questionar se a análise ontológica de tal ser pode se realizar no quadro teórico da própria fenomenologia ou se exige alguma ruptura com seus procedimentos.

A primeira nota de trabalho publicada em $O$ Visível e o Invisivel testemunha a favor da importância dos temas husserlianos na elaboração da ontologia de MerleauPonty. Ali, em referência a "O filósofo e sua sombra", o autor planeja "dar um quadro do Ser selvagem prolongando meu artigo sobre Husserl" (VI, 217, jan. 1959). Será que a referência ao filósofo alemão indica que o estudo desse ser selvagem (anterior aos atos de constituição) ocorrerá por meio de um tipo de fenomenologia? A sequiência da nota desfaz essa impressão: o desvelamento do ser selvagem entrevisto pela fenomenologia permanece "letra morta enquanto nós não desenraizamos a 'filosofia objetiva' (Husserl)" (Ibid.). A fenomenologia husserliana se limitaria a tratar de objetos, e, desse modo, restringiria as possibilidades de avançar na investigação do ser pré-reflexivo anunciado sob seus marcos. Merleau-Ponty também acentua outra limitação da fenomenologia: essa doutrina envolve "uma ontologia que submete tudo o que não é nada a se apresentar à consciência por meio das Abschattungen e como derivando de uma doação originária que é um ato, isto é, um Erlebnis entre outros" (VI, 293, abril 1960). A fenomenologia delimitaria o ser como aquilo que pode se manifestar à consciência e que, assim, se submete às capacidades sintéticas subjetivas. Veremos que Merleau-Ponty rejeita essa concepção ontológica, a qual não vigoraria somente na obra husserliana mas mesmo na fenomenologia praticada por ele mesmo nos anos quarenta. Antes, porém, vejamos como essas duas censuras (filosofia objetiva e limitação do ser àquilo que se apresenta à consciência) se complementam, ao menos no que se refere à Husserl.

Em vários momentos de sua obra, Husserl indica que, para aplicar a redução fenomenológica, deve-se suspender as crenças referentes à existência do mundo objetivo tal como considerado pelas ciências e pelo senso comum ${ }^{34}$. Desse modo, revelar-se-ia o mundo fenomênico anterior às idealizações objetivantes (mundo

implícita a um ser pré-reflexivo, e julga que "Descartes é o mais difícil dos autores" (NC, 264), porque tal referência é difusa e alimenta inúmeros mal-entendidos.

${ }^{34}$ Cf. Husserl, E. Ideen zu einer reinen Phänomenologie und phänomenologischen Philosophie I. Ed. supra, $\S 32$. 
chamado por Husserl, em A Crise das Ciências européias, de Lebenswelt ${ }^{35}$. No entanto, tal como nota Renaud Barbaras, o mundo da vida descrito por Husserl é "um mundo de coisas, quer dizer, entidades definidas, determinadas, idênticas a elas mesmas, sendo de direito o objeto de um saber exaustivo, em suma, acessíveis segundo seu eidos" ${ }^{\prime 36}$. Quer dizer que Husserl apresenta o mundo da vida como composto por entes plenamente determináveis, e, desse modo, ainda sobrepõe ao campo de fenômenos reduzidos a noção idealizada de objeto. Mas em que sentido a noção de objeto plenamente determinável implica a imposição de uma idealização sobre o campo fenomenal?

Segundo Husserl, o sujeito perceptivo se relaciona, em cada vivência, com alguns aspectos fenomênicos da coisa percebida. À medida que o sujeito altera seu ponto de vista perceptivo (e o pode fazer indefinidamente), apreende outros aspectos da coisa e deixa de perceber aqueles primeiros, de maneira que a percepção sempre apresenta alguns perfis, mas nunca a coisa em sua totalidade. Além disso, há a possibilidade de que aspectos ainda a serem percebidos pelo sujeito desmintam alguns outros já vivenciados e tomados até então como verdadeiros. Dessa maneira, as coisas percebidas se manifestam de maneira parcial e contingente ${ }^{37}$. Aqui poderia surgir um tipo de dúvida cética acerca dos resultados da percepção: se a vivência perceptiva é sempre limitada e falível, como pode o sujeito estar certo de apreender verdadeiramente uma coisa e não meras seqüências desconexas de aparências subjetivas? A tese husserliana que evita tal objeção compromete-o com a noção idealizada de objeto, conforme veremos a seguir.

Para Husserl, a coisa percebida não é senão o conjunto de aspectos fenomênicos que se manifestam numa série interminável, a qual, por sua vez, se ordena, assim formula Barbaras, como "progressão orientada",38. Já opera aqui uma primeira idealização não questionada por Husserl, aquela segundo a qual a infinidade definidora da coisa é uma seqüência de eventos linearmente percorrível. Merleau-Ponty teria notado que, se se atenta para a experiência fenomenal, o caráter infinito das coisas e do

\footnotetext{
${ }^{35}$ Cf. Husserl, E. Die Krisis der europäischen Wissenschaften und die transzendentale Phänomenologie. Ed. supra, § 36-38.

${ }^{36}$ Barbaras, R. Le Tournant de l'Expérience. Recherches sur la philosophie de Merleau-Ponty. Ed. supra, p.67.

${ }^{37}$ Cf. Husserl, E. Ideen zu einer reinen Phänomenologie und phänomenologischen Philosophie I. , Ed. supra, § 44-46.

${ }^{38}$ Barbaras, R. Op. cit., p.69.
} 
mundo não aparece dessa maneira ${ }^{39}$. Novamente Barbaras auxilia a esclarecer o ponto em questão: o infinito, em sua vivência pré-reflexiva seria apenas "a transcendência pura do mundo" 40 , quer dizer, o fato de que o ser sempre excede aquilo que os sujeitos dele vivenciam, mas o excede não de uma maneira seqüencialmente ordenada, e sim como latência de aspectos ou eventos apenas pressentidos (e não ordenados como algo a se percorrer).

Por meio de sua noção idealizada de infinidade ou infinito, Husserl sustenta que a coisa percebida porta uma unidade para além de suas manifestações parciais: se a infinidade de aspectos da coisa percebida se doa progressivamente para uma consciência, então, ao menos em princípio, a consciência poderia apreender adequadamente a coisa em sua totalidade. Afinal, as propriedades componentes das coisas fenomenais seriam correlatas de atos de consciência, os quais então assimilam sem perda toda a complexidade inerente às primeiras. Essa possibilidade (sustentada pela noção idealizada de infinito) garante que as manifestações parciais remetem verdadeiramente a uma coisa ${ }^{41}$. Quer dizer que as coisas percebidas não são parciais e inacabadas, mas incluem, ao menos idealmente, a possibilidade de determinação de todos os seus aspectos. Assim, na fenomenologia husserliana, as aparências parciais da percepção são coordenadas pela idéia de objeto, compreendido como ente cujas propriedades são passíveis de plena assimilação pela consciência ${ }^{42}$.

Agora é possível compreender por que Merleau-Ponty julga que a fenomenologia husserliana é uma filosofia objetiva. Tal fenomenologia sustenta que as aparências parciais e contingentes reveladas após a redução fenomenológica supõem um mundo de objetos determináveis. Também se torna possível entender porque a filosofia objetiva é justamente aquela que trata tudo o que existe como manifestação fenomênica para uma consciência. Embora suponha que as coisas são plenamente determináveis,

\footnotetext{
39 “É necessário que [o infinito] seja o que nos ultrapassa; infinito de Offenheit e não de Unendlichkeit infinito da Lebenswelt e não infinito de idealização" (VI, 221, junho 1959). Merleau-Ponty opõe, assim, o infinito idealizado (Unendlichkeit) ao verdadeiro infinito do mundo da vida. Em outra nota, MerleauPonty assevera: "a Unendlichkeit é no fundo em-si, ob-jeto" (VI, 300, maio 1960). Assim, a noção idealizada de infinito se liga à idéia de objeto determinado.

${ }^{40}$ Barbaras, R. Le tournant...,p. 69.

${ }^{41}$ Segundo Husserl, "a todo objeto 'que existe verdadeiramente' corresponde por princípio (no a priori da generalidade incondicionada de essências) a idéia de uma consciência possível na qual o próprio objeto pode ser apreendido de maneira originária e desde então perfeitamente adequada. Reciprocamente, se essa possibilidade é garantida, o objeto é, ipso facto, o que existe verdadeiramente" (Husserl, E. Ideen zu einer reinen Phänomenologie und phänomenologischen Philosophie I. Ed. supra,§ 142, p.296).

${ }^{42}$ Deve-se notar que essas considerações husserlianas acerca da determinação das propriedades objetivas pela consciência se referem ao domínio dos objetos intencionais e não àquele dos objetos puros e simples (ou seja, objetos considerados conforme a atitude natural). Quer dizer que essas considerações não apagam a distinção entre atitude natural e fenomenológica, mas a supõem.
} 
Husserl deve explicar seu aparente inacabamento e parcialidade. Essas características, que implicam a indeterminação da experiência perceptiva, são remetidas ao modo de funcionamento da consciência, a qual só é capaz de apreender, de uma só vez, poucos dados de uma realidade em si mesma completamente determinável. O aparecer fenomênico é então concebido como um interminável processo de perfilação de coisas (determináveis em si mesmas) a uma instância que reúne de maneira paulatina os aspectos parciais manifestados. Assim, a tese que limita todo ser a se manifestar por aspectos fenomênicos parciais complementa aquela segundo a qual a indeterminação não é uma característica da realidade, uma vez que essa é composta por objetos a priori determináveis pelos atos de consciência.

Por sua vez, Merleau-Ponty rejeita interpretar o campo fenomenal aberto pela redução fenomenológica como manifestação parcial de objetos em si mesmos determináveis. Essa concepção ontológica limita o alcance das descrições fenomenológicas em geral, circunscritas então à narrativa de propriedades parciais de objetos em correlação com atos de consciência. As dificuldades de Husserl para assumir como tema autônomo (e não como preâmbulo do puro transcendental) o ser préreflexivo entrevisto ao se tratar da Terra ou do corpo próprio decorreriam dessa limitação ontológica sobre a qual sua fenomenologia se erige. Para o filósofo alemão, a passagem ao transcendental envolve a postulação de que os temas descritos devem ser concebidos como objetos por princípio adequados, cuja aparente indeterminação se deve a limitações intrínsecas à consciência.

Já na Fenomenologia da Percepção Merleau-Ponty recusava a passagem a uma consciência transcendental que eliminaria qualquer obscuridade presente na experiência do mundo fenomênico (Cf. PhP, 419, nota). Além disso, nesse livro, o autor não idealiza a experiência perceptiva de maneira a sobrepor a seus aspectos indeterminados a noção de objeto em si mesmo determinável. Pelo contrário, o filósofo admite que a indeterminação e o inacabamento são componentes irredutíveis da experiência fenomenal ${ }^{43}$. Contudo, nesse livro, a rejeição da tese de que o ser se compõe de um conjunto de objetos idealmente determináveis não é acompanhada da recusa da tese que a complementa, a saber, que as coisas e o mundo, em sua totalidade, não são correlatos de atos de consciência. Tal como procuramos mostrar em nosso primeiro capítulo,

\footnotetext{
43 "No mundo tomado em si tudo é determinado. Há muitos fenômenos confusos, como uma paisagem em um dia de névoa, mas justamente nós sempre admitimos que nenhuma paisagem real é em si confusa. Ela só o é para nós. (...) [No entanto,] é necessário reconhecer o indeterminado como um fenômeno positivo" $(\mathrm{PhP}, 12)$.
} 
Merleau-Ponty, na Fenomenologia da Percepção, sustenta que o ser é exatamente aquilo que se manifesta para a consciência perceptiva (Cf. PhP, 455). Já em seus textos dos anos cinqüenta (conforme acompanhamos nos capítulos III e IV), o filósofo parece rejeitar a circunscrição do ser àquilo que se apresenta para a consciência subjetiva. Essa rejeição melhor se harmoniza com a tese de um ser em si mesmo indeterminado (já vislumbrada na Fenomenologia da Percepção), o qual, conforme tais textos, não se resume a propriedades determináveis pela consciência, já que excede aquilo que se doa à subjetividade. A exposição das características desse ser não depende das descrições fenomenológicas, já que essas tratam daquilo que se exibe à consciência. Para estudar as características que escapam à consciência imediata, que a ela são ausentes, o filósofo desenvolveu o seu método indireto, conforme expusemos no capítulo anterior.

A ontologia madura de Merleau-Ponty não é fenomenológica, no sentido em que ela não se limita a analisar o que se manifesta à consciência. No entanto, como vimos, as descrições fenomenológicas husserlianas que apontam para o ser primordial aquém dos atos de constituição subjetivos são índices da nova concepção de ser almejada. Além disso, alguns conceitos fenomenológicos podem ser reelaborados de modo a tomarem parte no quadro teórico de uma ontologia do ser bruto. A noção de horizonte, por exemplo, é tomada por Merleau-Ponty não (tal como era para Husserl) como consciência indeterminada de um conjunto de objetos que constituem o fundo ou entorno sensível de uma coisa percebida ou como consciência indeterminada da totalidade de aspectos dessa coisa ${ }^{44}$. Nas notas de leitura de Teoria do Campo da Consciência (livro de Gurwitsch), escritas em 1959-60, Merleau-Ponty afirma: “o horizonte não é a extensão da zona da visão clara em que se realizam essas estruturas [da consciência], ele é o meio dessas estruturas cristalizadas" ${ }^{\text {45 }} 46$. Assim, o horizonte seria um modo de ordenação de coisas e eventos inerente ao ser, modo segundo o qual a disposição espacial dessas coisas e eventos implica que uns se sobreponham parcialmente aos outros e instaurem uma profundidade imanente ao mundo.

A noção de Lebenswelt também é reformulada por Merleau-Ponty: ela deixa de ser concebida como conjunto de estruturas da experiência em correlação implícita com a

\footnotetext{
${ }^{44}$ Cf. Husserl, E. Die Krisis der europäischen Wissenschaften und die transzendentale Phänomenologie. Ed. supra, § 47.

${ }^{45}$ Merleau-Ponty, M. "Notes de lecture et commentaires sur Théorie du champ de la conscience de Aron Gurwitsch”. In: Revue de Métaphysique et de Morale, n. 3, 1997, p.332.

${ }^{46}$ Sobre a apropriação ontológica do tema fenomenológico do horizonte por Merleau-Ponty, cf. Fontaine,

P. “Le concept phénoménologique d'horizon”. In: Cahiers Philosophiques, n. 87, juin 2001, p. 9-31.
} 
consciência transcendental $^{47}$ e passa a indicar o mundo anterior à atividade constituinte da subjetividade, pátria do ser selvagem. Com essa reformulação, Merleau-Ponty responde à crítica de Gurwitsch segundo a qual teria tomado injustificadamente o mundo percebido como fato último na Fenomenologia da Percepção. Gurwitsch insistia em buscar a gênese desse mundo nos atos constituintes da consciência transcendental. Por sua vez, Merleau-Ponty defende em suas notas de leitura: "não há sentido em constituir a Lebenswelt, seria destruí-lo"48. A análise constitutiva fenomenológica fornece as leis eidéticas segundo as quais certos tipos de atos de consciência se relacionam com certos tipos de manifestação fenomênica. Ora, essa explicitação das estruturas eidéticas de correlação entre noeses e noemas supõe, assim julga MerleauPonty, a experiência dos fatos (justamente dos quais se busca as características invariantes). Por conseguinte, "o mundo como Ser (...) é a fonte do eidos mundo"49, ou seja, há uma anterioridade da existência mundana em relação à formulação das essências, as quais exibem os traços invariantes desse mundo. Quer dizer que uma análise constitutiva do mundo percebido, tal como sugeria Gurwitsch, supõe o ser desse mundo, ser que não é produto de nenhuma atividade intencional mas que funda a possibilidade de qualquer uma delas. A gênese dos fenômenos não será então remetida por Merleau-Ponty à consciência transcendental; na verdade, para entendê-la, trata-se de buscar o "desvelamento do Ser selvagem ou bruto pelo caminho de Husserl e da Lebenswelt sobre o qual se abre" (VI, 234, fev. 1959). Desse modo, não é por uma fenomenologia transcendental que se pode esclarecer o sentido dos fenômenos da Lebenswelt, mas sim por uma ontologia que exponha as principais características do ser do mundo sensível. Essa ontologia, que não está comprometida com os procedimentos e resultados gerais da fenomenologia, é esboçada por Merleau-Ponty em $O$ Visível e o Invisível, como veremos no capítulo seguinte.

\footnotetext{
${ }^{47}$ Cf. Husserl, E. Die Krisis der europäischen Wissenschaften und die transzendentale Phänomenologie. Ed. supra, § 55 .

${ }^{48}$ Merleau-Ponty, M. "Notes de lecture et commentaires sur Théorie du champ de la conscience de Aron Gurwitsch”. Ed. supra, p.338.

${ }^{49}$ Id., ibid.
} 


\section{Capítulo VI - Uma ontologia para a fé perceptiva}

\section{Sinopse}

De início, expomos como o tema da fé perceptiva é apresentado em O Visível e o Invisível por contraste com a Fenomenologia da Percepção. Em seguida, acompanhamos a enumeração das dificuldades das doutrinas clássicas em lidar com tal tema. Por fim, esclarecemos a doutrina ontológica que torna a fé perceptiva compreensivel teoricamente.

\section{A) A fé perceptiva}

\section{A última filosofia de Merleau-Ponty}

Neste capítulo, estudaremos $O$ Visível e o Invisível a fim de esclarecer as linhas gerais do projeto ontológico final de Merleau-Ponty, além de acentuar algumas diferenças entre a reflexão aí esboçada e aquela desenvolvida na Fenomenologia da Percepção. Vamos nos concentrar em alguns tópicos dos quatro capítulos e no pequeno anexo do livro, sem nos deter nas notas de trabalho, as quais serão consideradas com mais detalhes no próximo capítulo. De início, é importante notar que a meta da investigação filosófica apresentada por $O$ Visível e o Invisível é exprimir a experiência silenciosa, o contato perceptivo (anterior à atividade reflexiva) com o mundo (Cf. VI, 18, 164). Merleau-Ponty chega mesmo a retomar a famosa frase de Husserl que já guiava as análises da Fenomenologia da Percepção ("é a experiência ainda muda que se trata de levar à expressão pura de seu próprio sentido" ${ }^{\text {) }}$ ) e com ela encerra o terceiro capítulo de $O$ Visível e o Invisível (Cf. VI, 169), como que resumindo a discussão precedente sobre a natureza da interrogação filosófica.

Buscamos diferenças entre $O$ Visível $e$ o Invisível e a Fenomenologia da Percepção, e, no entanto, já admitimos de início que a meta filosófica de ambos é a mesma: a Fenomenologia da Percepção almejava explicitar a experiência pré-reflexiva (Cf. PhP, XIII, 75), um mote reiterado por $O$ Visível e o Invisível. Essa reiteração poderia sugerir que Merleau-Ponty retoma a análise fenomenológica em seu último livro. Mas isso só seria verdadeiro se a investigação da experiência pré-reflexiva exigisse o método fenomenológico. É verdade que ao praticar a fenomenologia, nos anos quarenta, Merleau-Ponty investigou a experiência antepredicativa, mas não se

\footnotetext{
${ }^{1}$ Husserl, E. Cartesianische Meditationen und Pariser Vorträge. Hua I. Haag: Martinus Nijhoff, 1950, segunda meditação, § 16. Na Fenomenologia da Percepção, essa frase é mencionada na p.X.
} 
segue daí que todo estudo de tal experiência implique a abordagem fenomenológica. Defenderemos que, embora o autor retome em $O$ Visível e o Invisível alguns dos principais temas da Fenomenologia da Percepção, o resultado final oferecido pelos quatro capítulos esboçados daquele livro não é uma análise fenomenológica, e sim uma interrogação ontológica que chega mesmo a romper com alguns princípios da fenomenologia. A retomada dos temas fenomenológicos ocorre não porque MerleauPonty se dedica a uma nova análise fenomenológica, mas porque o filósofo se preocupa em recuperar algumas teses da Fenomenologia da Percepção no contexto de uma nova ontologia, cujos traços principais tentaremos delinear a seguir ${ }^{2}$.

\section{Da percepção à fé perceptiva}

$O$ Visível e o Invisível se inicia com a exposição, ainda não filosoficamente elucidada, da experiência da fé perceptiva. Por meio dessa noção, Merleau-Ponty tenta capturar a "crença" (independente de qualquer esforço reflexivo) pela qual normalmente os sujeitos acreditam estar em contato com o mundo tal como ele existe em si mesmo ${ }^{3}$. O filósofo parece simplesmente repetir o sentido que já atribuíra à noção de fé perceptiva na Fenomenologia da Percepção. Ali, Merleau-Ponty associava tal noção à consciência pré-reflexiva e à vida perceptiva em geral: a "fé perceptiva" apenas explicita o sentido de "percepção", ao tornar patente o fato de que a atividade perceptiva adere ao mundo mesmo sem dispor de dados absolutamente certos e mesmo sem realizar verificações teóricas que atestassem a certeza de suas visadas (Cf. PhP, 344, 371, 395, 415, 468). Porém, o uso da expressão "fé perceptiva" em $O$ Visível e o Invisível veicula certas decisões filosóficas pelas quais o filósofo se afasta de suas posições anteriores. É o que fica claro no anexo de seu último livro. Ali, Merleau-Ponty esclarece que pretende investigar o contato com o mundo bruto, e, para tanto, interroga a experiência ingênua tal como ela aparece para o "homem natural" (VI, 210), quer dizer, aquele que não reflete sobre sua vivência. Vimos em nosso primeiro capítulo que a Fenomenologia da Percepção também pretendia descrever a experiência ingênua, e que, desse modo, mais uma vez as semelhanças parecem se sobrepor às diferenças entre o início e o fim da obra do filósofo. No entanto, tais diferenças se tornam mais salientes quando Merleau-Ponty afirma, na seqüência do anexo, que os conceitos filosóficos ou

\footnotetext{
${ }^{2}$ Segundo Merleau-Ponty, há a "necessidade de levar [os resultados da PhP] à explicitação ontológica" (VI, 234, fev. 1959).

3 "Nós vemos as próprias coisas, o mundo é o que nós vemos" (VI, 17).
} 
psicológicos tradicionais não são adequados para descrever a experiência ingênua, já que muitas vezes eles impõem sobre ela distinções teóricas artificiais. Esse seria o caso do termo "percepção", que pressuporia a cisão do fluxo vivido em diferentes atos perceptivos, cada um em referência a coisas determinadas. Além disso, o termo "percepção" se aplicaria, no mais das vezes, a coisas materiais e espaciais, o que parece excluir qualquer relação de algo invisível com o mundo percebido (Cf. VI, 207). Para Merleau-Ponty, a experiência da abertura originária para o mundo desconhece tais restrições. Não é claro, de início, que a experiência bruta do mundo seja de coisas bem definidas em correlação com atos pontuais, ou que um domínio invisível não se mostre indiretamente, por meio do que é dado aos sujeitos. Por julgar que o termo "percepção" já decide esses pontos de maneira injustificada, Merleau-Ponty o abandona em favor de "fé perceptiva", descrição pretensamente neutra em relação aos temas mencionados.

Surpreendente nessa análise terminológica é que Merleau-Ponty parecia utilizar o termo "percepção" sem implicar seja uma referência a coisas definidas seja a exclusão de um domínio invisível. A Fenomenologia da Percepção considera que jamais se percebe as coisas por inteiro, já que elas sempre se mostram de maneira parcial $^{4}$. E não só as coisas não são percebidas como objetos bem definidos, mas também algo que não é "coisa", o horizonte, (e, por meio dele, toda a amplidão do mundo) também é percebido $^{5}$. Além disso, Merleau-Ponty considera que mesmo a ausência dos objetos também é percebida ${ }^{6}$. Não deixa, por conseguinte, de ser estranha a recusa de um vocábulo por atribuir a ele um sentido que a própria Fenomenologia da Percepção expusera que não lhe cabia exclusivamente. Porém, embora as razões apresentadas pelo anexo de $O$ Visível e o Invisível não pareçam ser suficientes para o abandono do termo "percepção", a idéia geral de que a "fé perceptiva" não está comprometida com certas decisões teóricas pelas quais a "percepção" era definida nos anos quarenta se confirma. Para explicitar tal confirmação, devemos retornar ao início de $O$ Visível e o Invisível.

Conforme apontamos há pouco, $O$ Visível e o Invisível se abre com a exposição da opinião injustificada (trazida pela experiência perceptiva) de que estamos em contato

\footnotetext{
4 "Ver é entrar em um universo de seres que se mostram, e eles não se mostrariam se eles não pudessem esconder-se uns atrás dos outros ou atrás de mim" (PhP, 82$)$.

5 "Quando eu olho o horizonte, ele não me faz pensar nessa outra paisagem que eu veria se eu lá estivesse, essa em uma terceira paisagem e assim por diante, eu não me represento nada, mas todas as paisagens estão já aí no encadeamento concordante e na infinidade aberta de suas perspectivas" (PhP, 380).

6 "O percebido não é necessariamente um objeto presente diante de mim como termo a conhecer, ele pode ser uma 'unidade de valor' que só me é presente de um modo prático. Se se retirou um quadro de um cômodo em que habitamos, nós podemos perceber uma mudança sem saber qual" ( $\mathrm{PhP}, 371$ ).
} 
com o mundo tal como ele é. Em seguida, Merleau-Ponty indica que, embora vivida de maneira simples e convincente, essa fé perceptiva leva a um paradoxo quando teorizada. Ocorre que a vivência da fé perceptiva admite de bom grado que o contato com o mundo se dê por intermédio da atividade do corpo e dependa das capacidades desse último. Porém, o corpo porta uma ambigüidade insuperável: por meio dele se atinge as coisas mesmas mas também é possível se isolar em aparências fantasmáticas, eventos reveladores dos limites e da falibilidade da atividade corporal (Cf. VI, 21-23). O corpo, dessa maneira, é meio de acesso e de afastamento em relação ao mundo, e, mesmo assim, o sujeito perceptivo ingênuo crê atingir o próprio mundo por meio dele. Essa pretensão ou fé perceptiva não é problemática na experiência ingênua. No entanto, quando formulada em tese, tal como fizemos, gera um saber paradoxal. É como se uma tese de cunho objetivo (o mundo se apresenta tal como é) devesse ser compatibilizada com uma tese de cunho subjetivo (o mundo é o que se apresenta por meio das estruturas corporais). Trata-se de uma junção teoricamente difícil, uma vez que não parece ser possível atingir sempre o mundo tal como ele é por meio de estruturas corporais, as quais por vezes somente apresentam imagens subjetivas, a que nada de real corresponde. Um dos grandes desafios de $O$ Visível e o Invisível, uma vez admitida a interrogação da experiência ingênua como tarefa da filosofia, é tornar teoricamente compatíveis essas características da fé perceptiva. Como veremos, será por meio do desenvolvimento das noções ontológicas sugeridas pelo método indireto que tal meta poderá ser cumprida. Esse desenvolvimento implica distinguir a fé perceptiva da consciência pré-reflexiva ou percepção tal como concebida nos anos quarenta.

Lembremos que na Fenomenologia da Percepção, a consciência perceptiva era o fundo silencioso de todos os atos subjetivos e a responsável (dado seu contato direto com o mundo) pela distinção entre realidade e sonho (Cf. PhP, XI). Além de definir a percepção como fonte de nossa relação com o ser, Merleau-Ponty, conversamente, definia o ser como aquilo passível de se manifestar de modo fenomênico (Cf. PhP, 455), ou seja, como o que é composto por propriedades subjetivamente apreensíveis. Todo ente ou evento que pareça escapar aos limites da experiência humana (como o passado do mundo, por exemplo) era reduzido a construções culturais, a significações tardias erigidas sobre a experiência pré-reflexiva (Cf. $\mathrm{PhP}, 494)$, a qual acaba por delimitar a amplitude daquilo que existe.

É exatamente essa delimitação subjetiva do ser que é rompida em $O$ Visível e o Invisível. O mundo é aquilo que aparece, mas também o mundo é dado por meio do 
corpo e limitado ao domínio exploratório desse último, eis o duplo sentido da fé perceptiva. O corpo tanto leva a subjetividade até o mundo como também pode afastá-la dele, dadas as limitações das estruturas corporais (especializadas em apenas alguns aspectos do ser, tais como a visibilidade e a tangibilidade). Uma vez exposta essa dupla característica da fé perceptiva, Merleau-Ponty extrai a seguinte conclusão: o mundo não é só o que eu percebo em uma "proximidade absoluta" (VI, 23), ele também está numa "distância irremediável" (Ibid.), pois a sua presença depende de condições corporais que podem ser insuficientes para apresentá-lo em sua totalidade. Assim, a experiência perceptiva não implica, em $O$ Visível e o Invisível, uma correlação exaustiva com o real, já que a abertura inicial ao mundo não exclui de direito uma ocultação possível (Cf. VI, 48). Como nota Merleau-Ponty, "a certeza que eu tenho de estar vinculado ao mundo por meu olhar me promete já um pseudo-mundo de fantasmas se eu o deixo errar" (VI, 47). Fé e incredulidade estão unidas na experiência perceptiva, assevera $O$ Visível e o Invisível. Daí que a abertura originária ao ser não possa mais ser identificada à percepção, tal como descrita nos anos quarenta. Segundo O Visível e o Invisível, embora o mundo se revele ao sujeito pela atividade perceptiva, essa apresentação depende de estruturas que não abrangem a totalidade daquilo que existe. Há a possibilidade de que o ser se oculte à atividade perceptiva, ou seja, de que as estruturas corporais não apreendam a sua totalidade, ressalva ausente na Fenomenologia da Percepção. Nesse livro, conforme vimos no primeiro capítulo, tudo o que escapa à experiência atual do corpo era ainda concebido como estrutura perceptivelmente apreensível. O caráter autônomo do mundo era concebido como uma infinidade de relações expressivas entre os eventos, a qual jamais poderia ser apreendida de uma só vez pelo corpo e se reduzir, assim, a um mero correlato subjetivo (Cf. PhP, 373-4). No entanto, nenhuma dessas relações constitutivas do em-si mundano excediam por princípio as capacidades perceptivas, as quais dispunham da lógica total da organização dos fatos mundanos (Cf. PhP, 377).

Por sua vez, em $O$ Visível e o Invisível, ao tratar da experiência perceptiva em termos de abertura e encobrimento do ser, Merleau-Ponty abandona a estrita correlação entre realidade e conteúdo perceptivo: a manifestação perceptiva do mundo não anula mas antes alimenta (dada a forma como se cumpre, por meio do corpo) a possibilidade de ocultação de ao menos parte do ser. Por meio dessa interpretação da fé perceptiva, Merleau-Ponty não mais se compromete com a tese de que tudo o que existe $o u$ deve se conformar aos parâmetros perceptivos ou então deve ser considerado uma significação 
cultural construída sobre esses parâmetros (Cf. PhP, 494). Em O Visível e o Invisível, uma tese semelhante é atribuída à filosofia reflexiva, para quem "é fora de questão que o mundo possa preexistir à minha consciência do mundo" (VI, 70). É para esse tipo de filosofia (a qual atribui ao pensamento humano o papel de organizador da experiência) que não há interrogação "sobre o que pode ser o Ser antes que ele seja pensado por mim" (VI, 72). Segundo a filosofia reflexiva, os objetos mundanos devem corresponder à atividade constitutiva do sujeito, ou seja, devem ser moldados segundo os poderes de síntese desse último. Na Fenomenologia da Percepção, esse tipo de limitação da amplitude do ser conforme as capacidades subjetivas de reconhecimento ainda continuava em vigor, embora não mais em relação ao pensamento e sim às estruturas perceptivas do corpo. Por meio da atividade perceptiva, o corpo era responsável, nesse livro, por atribuir uma estrutura ordenada ao mundo (Cf. PhP, 494). Desse modo, o sujeito perceptivo descrito por Merleau-Ponty repetia a função geral que o sujeito cognitivo exerce na filosofia reflexiva ${ }^{7}$. Em $O$ Visível $e$ o Invisível, o filósofo problematiza essa concepção: a abertura perceptiva apresenta o mundo, mas não em sua totalidade, pois o ser pode se encobrir ante as estruturas corporais, ou seja, pode não se doar diretamente como visível, tangível, etc., mas permanecer como aspecto ou dimensão invisível, que só se doa originariamente como ausência ${ }^{8}$.

\footnotetext{
${ }^{7}$ Seguimos, quanto a esse ponto, a interpretação de Vincent Peillon (La Tradition de l'Esprit. Itinéraire de Maurice Merleau-Ponty. Paris: Bernard Grasset, 1994, p.150-1). Esse autor defende que embora Merleau-Ponty sustente uma concepção de sujeito bem diferente daquela de Descartes ou Kant (filósofos tachados de intelectualistas na Fenomenologia da Percepção), seus resultados são convergentes com os desses autores. Merleau-Ponty censura Descartes e Kant por favorecerem o sujeito como constituinte das relações com o mundo. Entre sujeito e mundo deveria haver relações "rigorosamente bilaterais" (PhP, IV), isto é, esses autores deveriam considerar que ambos os pólos, subjetivo e objetivo, contribuem igualmente para a elaboração da experiência vivida. No entanto, dificilmente o próprio Merleau-Ponty sustentaria tal reciprocidade entre sujeito e mundo. Embora tente reconhecer uma transcendência inerente ao mundo, ou seja, uma densidade e autonomia que escapam aos poderes da consciência, Merleau-Ponty acaba por defender que é o próprio sujeito que atribui transcendência ao mundo (já que em seu movimento de existir, sempre se lança para fora de si e molda assim um campo ontológico exterior a si), e que as articulações e estruturas que compõem o mundo são aquelas que correspondem às capacidades perceptivo-motoras do sujeito (Cf. PhP, 491-2). É claro que para o fenomenólogo francês o sujeito da experiência é o corpo próprio, o qual não forja representações de objetos baseadas em categorias formais, mas se refere a situações que se perfilam gradualmente e jamais são possuídas por completo (Cf. $\mathrm{PhP}, 163$, nota). Mas mesmo ao apresentar como sujeito da percepção não uma consciência conceitual e sim o corpo, Merleau-Ponty ainda defende na Fenomenologia da Percepção que é por meio de poderes subjetivos (no caso, não poderes intelectuais, mas perceptivo-motores) que o mundo recebe a sua estrutura geral (Cf. PhP, 494).

${ }^{8} \mathrm{E}$ essa dimensão invisível estrutural, que de direito escaparia aos poderes perceptivos, não se confunde com os casos em que ocorre a percepção da ausência de determinados objetos (tal como Merleau-Ponty considerava na Fenomenologia da Percepção - cf. nota 6 supra). Nesses últimos casos, o ausente em questão poderia ser assimilado como presença, como algo que se doa positivamente; por sua vez, não há essa possibilidade em relação à dimensão invisível do ser.
} 
Françoise Dastur resume de maneira bastante elucidativa esse ponto ao expor o que está implicado no uso da expressão "fé perceptiva" em O Visível e o Invisível: "esta abertura, que é a experiência, pode nos abrir a uma ausência originária e não somente a uma presença originária, de modo que não nos é mais possível opor estritamente presença e ausência, visibilidade e invisibilidade, mas nos é necessário, antes, analisar [faire l'épreuve de] seu mútuo entrelaçamento"9. Assim, ao tratar do contato com o mundo em termos de fé perceptiva em $O$ Visível e o Invisível, Merleau-Ponty não retoma as virtudes da consciência perceptiva descrita pela Fenomenologia da Percepção, mas considera a possibilidade de que o ser se encubra, e que, por conseguinte, não se esgote em sua presença perceptiva.

\section{O problema da ilusão}

Em $O$ Visível e o Invisível Merleau-Ponty não descreve mais a experiência perceptiva apenas como abertura, mas também como encobrimento do ser. Essa última característica esclarece a especificidade do sentido de "fé perceptiva" ante o termo "percepção", tal como usado pelo filósofo nos anos quarenta. Notemos que ao exemplificar o encobrimento inerente à fé perceptiva, Merleau-Ponty assevera que o corpo pode gerar um pseudo-mundo fantasmagórico (Cf. VI, 47). Esse tipo de exemplo pode nos levar a crer que todo o problema da fé perceptiva se restringe ao reconhecimento de que os poderes perceptivos não estão imunes a erros ou ilusões. Ora, não é nesse ponto que o projeto filosófico da Fenomenologia da Percepção e de $O$ Visível e o Invisível se distinguem. No primeiro desses livros, Merleau-Ponty já trata do tema da ilusão sensível e oferece uma análise que, na verdade, O Visível e o Invisível retoma em seus termos gerais. No livro de 1945, o filósofo admitia que uma aparência perceptiva tomada isoladamente pode ser enganosa. Afinal, cada ato perceptivo apreende apenas dados parciais das coisas e situações, e adere a seu conteúdo (nele crê, poderíamos dizer) mesmo sem abarcar todos os componentes daquilo que se doa à percepção. No entanto, os dados parciais sempre envolvem espontaneamente outros dados co-percebidos, que instituem horizontes de verificações passíveis de exploração ${ }^{10}$ (por exemplo, se vejo uma face de uma caixa de papelão, "percebo" concomitantemente suas outras faces, as quais meu olhar busca de maneira espontânea como expectativas

\footnotetext{
${ }^{9}$ Dastur, F. "La foi perceptive et l'invisible”. In: Chair et Langage. Paris: Encre Marine, 2001, p.115.

${ }^{10}$ São dois os horizontes: o interno, referente aos aspectos que compõem a coisa percebida, e o externo, referente ao fundo sensível sobre o qual a coisa se destaca.
} 
que complementariam essa percepção da face isolada). É por meio da exploração desses horizontes (aos quais toda visada parcial se liga espontaneamente) que se pode reconhecer uma ilusão (por exemplo, ao procurar a face lateral da caixa e nada encontrar, meu olhar reconhece que se tratava somente de uma imagem bidimensional que imitava uma caixa). A ilusão se caracteriza, assim, como um dado aberrante, que destoa do encadeamento harmônico de aspectos percebidos. Há então uma relação cerrada entre a possível falha de percepções individuais e a sua substituição por apreensões perceptivas mais confiáveis (Cf. PhP, 343, 396). Quanto mais concordante a exploração dos horizontes co-percebidos, mais confiável se torna a percepção de uma certa coisa ou situação. E quanto mais confiável essa percepção, conhece-se as estruturas do mundo de maneira mais precisa, embora não de maneira absolutamente completa, já que em princípio toda percepção pode ser corrigida por visadas futuras. Acentuemos que em $O$ Visível e o Invisível, Merleau-Ponty volta a definir a ilusão sensível por seu contraste com a explicitação concordante dos horizontes perceptivos. Esse processo de desilusão é apresentado como meio para uma "experiência definitiva do 'real'" (VI, 63), a qual apreende de maneira confiável e precisa alguns aspectos do mundo.

É preciso cuidado ao correlacionar esse problema da diferença entre experiência verdadeira e ilusória com aquele da distinção, propiciada pela fé perceptiva, entre abertura ao mundo e encobrimento do ser. A compreensão errada desses temas nos levaria a perder a originalidade de $O$ Visível e o Invisível ante a Fenomenologia da Percepção. Consideremos um primeiro esquema do problema:

1) Fé perceptiva

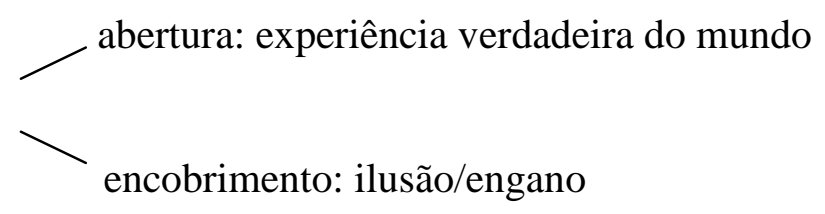

Sabemos que para Merleau-Ponty a fé perceptiva se compõe de duas dimensões, abertura ao mundo e seu encobrimento. Se se identifica a abertura à experiência da realidade e o encobrimento à ilusão, então não haveria como distinguir entre verdade e engano perceptivo, já que ambos corresponderiam a características constituintes da experiência perceptiva, conforme a exposição da fé perceptiva no início de $O$ Visível e $O$ Invisível. A fim de manter a possibilidade de distinção segura entre experiência verdadeira e ilusória seria necessário, segundo essa primeira interpretação, atribuir um 
privilégio muito maior à abertura que ao encobrimento, o qual seria compreendido como visada enganosa a ser corrigida pelo processo de exploração de horizontes propiciado pela abertura geral ao mundo. Por conseguinte, perder-se-ia a originalidade da fé perceptiva, ou seja, o fato de que nela há uma presença irrecusável do ser sem que isso exclua a sua distância irremediável.

A fim de harmonizar as características da fé perceptiva e a distinção entre experiência verdadeira e ilusória, propomos o seguinte esquema:

2) Fé perceptiva:

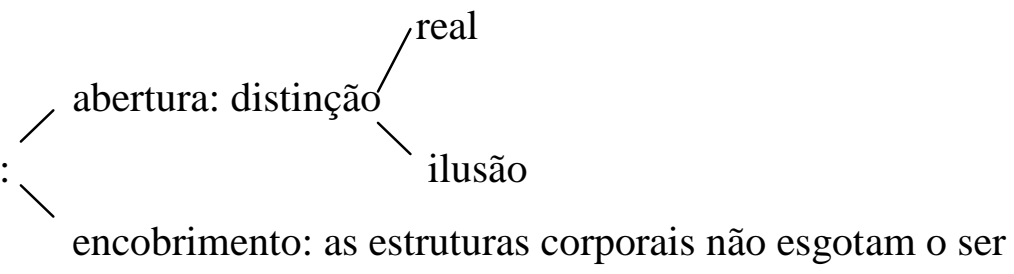

Nessa interpretação, não há incompatibilidade entre as dimensões da fé perceptiva e a eficácia desta em distinguir experiência verdadeira e ilusória, uma operação que ocorre no interior da abertura do mundo, ou seja, no interior da experiência das coisas tal como elas são. Essa operação não anula, entretanto, a dimensão de encobrimento inerente à fé perceptiva, dimensão que decorreria das características estruturais do corpo. Por sua vez, reconhecer uma dimensão de encobrimento na fé perceptiva não significa afirmar que o corpo está encerrado em ilusões e jamais nos dará o mundo tal como ele é. De fato, naquilo que o corpo percebe, a distinção entre experiência verdadeira e ilusória ocorre de maneira bastante satisfatória, tal como a análise da desilusão evidenciou. Porém, com a noção de encobrimento ontológico, Merleau-Ponty parece indicar que o ser pode ser composto, ao menos parcialmente, de propriedades que nossas capacidades perceptivas não reconhecem, de propriedades invisíveis, que se ocultam para os poderes imediatos de nossa estrutura corporal, e em relação às quais não faz sentido aplicar a distinção entre experiência verdadeira e ilusória.

O encobrimento ontológico e o problema da distinção entre percepção verídica e ilusória são de ordens distintas. É possível, por conseguinte, conciliar a tese de um ser que não se reduz à sua manifestação subjetiva (ser que envolve dimensões invisíveis) e a capacidade perceptiva de diferenciar experiência verídica e ilusória: o fato de que possa haver mais ser do que aquele apreendido diretamente, quer dizer, de que o ser pode se ocultar para nosso aparato perceptivo-motor imediato, não implica que no âmbito do ser percebido não possa haver a distinção mencionada. E que essa distinção 
ocorra, não implica que as propriedades subjetivamente apreensíveis esgotem todas as estruturas ontológicas do mundo. Assim, por exemplo, é possível diferenciar entre a percepção de uma paisagem marítima à luz matinal e uma miragem, embora vários componentes dessa paisagem percebida (os raios ultravioletas, por exemplo) sejam elementos do mundo ocultos para o corpo, elementos que não se revelam diretamente para a percepção humana.

Até agora, preocupamo-nos em esclarecer que as características da fé perceptiva não se reduzem às capacidades de distinção entre experiência verdadeira e ilusória. Mas ainda falta explorar justamente aquilo que constitui de maneira positiva a fé perceptiva: misto de apresentação e recuo do mundo. Toda a dificuldade é compreender como as possibilidades de abertura e encobrimento contidas na fé perceptiva não se contrariam, e, que a experiência ingênua, apresente o mundo por meio de capacidades perceptivas subjetivas. Como bem formula Merleau-Ponty, o problema da fé perceptiva é que ela "paradoxalmente nos assegura levar-nos às próprias coisas, dando-nos acesso a elas por meio do corpo, que, portanto, nos abria para o mundo, fechando-nos na série de nossos acontecimentos privados" (VI, 50). Falta ainda expor a exploração filosófica de Merleau-Ponty que compatibiliza as teses aparentemente opostas veiculadas pela fé perceptiva.

\section{B) As teorizações sobre a fé perceptiva}

\section{Esquema geral}

Antes de oferecer sua resposta, Merleau-Ponty analisa o tratamento dado ao problema da fé perceptiva por diferentes empreitadas teóricas. No decorrer dessa análise, ao tornar claras as limitações dessas empreitadas, Merleau-Ponty delineia a forma de interrogação filosófica conveniente para investigar a fé perceptiva. Vamos acompanhar as linhas gerais dessa análise crítica contida nos três primeiros capítulos de O Visível e o Invisível, para então finalmente expor a abordagem positiva do tema em questão, contida no quarto capítulo desse livro.

Lembremos que a fé perceptiva impõe uma mistura entre uma tese de cunho objetivo (o mundo se apresenta tal como é) e uma de cunho subjetivo (o mundo se apresenta por meio das capacidades perceptivas). As duas primeiras empreitadas teóricas estudadas por Merleau-Ponty se caracterizam por romper essa tensão interna à atividade perceptiva e privilegiar apenas um dos aspectos da complexa experiência originária que se tratava de esclarecer. A primeira delas é a ciência objetivista, que faz 
da experiência perceptiva o resultado de relações materiais determinadas causalmente. Por conseguinte, o paradoxo da fé perceptiva é dissolvido em favor da exposição do mundo tal como ele é. A segunda delas é a filosofia reflexiva, que acentua em demasia o papel das capacidades subjetivas na apresentação do mundo, o qual deve se conformar às possibilidades internas da subjetividade cognoscente. Não reproduziremos aqui todos os tópicos examinados por Merleau-Ponty quanto a esses dois métodos teóricos (o científico e o reflexivo). Interessa-nos somente mostrar os problemas de ambos em relação à fé perceptiva.

\section{Análise da ciência}

Para Merleau-Ponty, as pesquisas objetivistas (no sentido já especificado no quarto capítulo) tentam reconstruir a experiência perceptiva como efeito de processos causais puramente físicos. No entanto, essa reconstrução, julga o filósofo, longe de dissipar a importância da fé perceptiva como contato primordial com o mundo, pressupõe-na (Cf. VI, 31). Afinal, tais pesquisas, que tomam os dados fenomenais como meros índices de relações físicas, admitem que as operações matemáticas, pelas quais essas relações são descritas, são adequadas ao ser objetivo, quer dizer, se conformam a ele e o descrevem tal como ele é. Ora, essa admissão transporta de maneira acrítica a crença perceptiva no contato direto com o mundo para a investigação científica (Cf. VI, $32,35,36-7)^{11}$. Haveria, assim, uma ambigüidade das pesquisas objetivistas em relação à fé perceptiva: ao mesmo tempo em que elas a reduzem a um efeito de relações causais objetivas, tais pesquisas se servem da crença fundamental veiculada por tal fé (atingir diretamente o ser), a qual é reproduzida no nível da relação entre aparato científico e ser objetivo.

Além de pressupor o modo pelo qual a atividade perceptiva se dirige para o ser, as pesquisas objetivistas deveriam reconhecer, sugere Merleau-Ponty, que a própria experiência perceptiva é, em alguma medida, uma condição para o entendimento dos sistemas físicos. Segundo o filósofo, a física contemporânea teria explicitado que as propriedades das partículas não são descritíveis em termos puramente objetivos, mas sim em relação à experiência do observador. Segue-se que tal experiência não é só efeito de relações exteriores a ela, mas parte indispensável do sistema natural físico a

\footnotetext{
${ }^{11}$ Vimos no segundo capítulo que Merleau-Ponty defendera tese semelhante, em A Prosa do Mundo, quanto à interpretação realista das entidades matemáticas. Essa interpretação, segundo a qual haveria um mundo de entes matemáticos independente de nosso conhecimento, reproduz a crença em um mundo independente da subjetividade, crença que se origina na atividade perceptiva (Cf. PM, 172-3).
} 
ser compreendido (Cf. VI, 31-2) ${ }^{12}$. Dessa maneira, os resultados da física de partículas sugerem uma reforma ontológica que substitua as noções opostas de objeto físico e de interioridade psíquica por aquela de campo de experiência. Merleau-Ponty lamenta que tal reforma não tenha ocorrido plenamente, uma vez que os resultados experimentais inovadores são comumente traduzidos para a ontologia objetivista tradicional $^{13}$. No entanto, importa notar, e não só no âmbito da física, mas também da psicologia ${ }^{14}$, a insuficiência da abordagem que supõe de antemão a antinomia entre um domínio objetivo e um subjetivo. Para Merleau-Ponty, a abertura perceptiva ao mundo repugna essa distinção e sustentá-la implica, assim, a recusa em compreender a complexidade pela qual o mundo se mostra para nós. Infelizmente, julga o filósofo, as abordagens científicas mais difundidas são aquelas que pressupõem tal distinção (e favorecem o ser objetivo como causa do subjetivo), e, desse modo, elas devem ser deixadas da lado na investigação da fé perceptiva. Por sua vez, a crítica às abordagens objetivistas não compromete Merleau-Ponty com uma perspectiva anti-científica, a qual, por exemplo, circunscreveria um conjunto de fatos que por princípio escaparia aos métodos científicos (Cf. VI, 40, 46). A fé perceptiva não é um tema por princípio alheio à análise científica; porém, uma vez que o objetivismo compõe a metodologia em voga na maior parte das investigações científicas, trata-se de um tema que não é adequadamente estudado por essas últimas ${ }^{15}$.

\section{A filosofia reflexiva}

Após a análise da ciência, Merleau-Ponty passa a expor as diferentes estratégias da filosofia ante a fé perceptiva. Vimos que a ciência, tal como exposta acima, tentava assimilar o caráter irremediavelmente subjetivo da apresentação do mundo a relações objetivas. Essa assimilação dissolvia o paradoxo da fé perceptiva, embora a perspectiva ingênua de atingir o mundo tal como ele é continuasse atuante ao menos na metodologia objetivista. Já a primeira variante filosófica examinada em $O$ Visível e o Invisível, a

\footnotetext{
${ }^{12}$ Vimos, no terceiro capítulo, que Merleau-Ponty já defendera, nos cursos editados em A Natureza, a tese de que os conteúdos percebidos devem servir de modelo às teorias físicas.

${ }^{13}$ Merleau-Ponty já explorara as dificuldades da ciência em aceitar uma nova ontologia em A Estrutura do Comportamento (Cf. SC, 33, 84, 145).

${ }^{14}$ Merleau-Ponty analisa a Gestalttheorie, a psicologia social e a psicofisiologia (Cf. VI, 37-47).

${ }^{15}$ Lembremos, tal como expusemos no quarto capítulo, que o objetivismo não é um componente essencial da ciência, mas uma opção metodológica com determinadas consequiências ontológicas. Para MerleauPonty, "nenhuma ontologia específica é requerida pela investigação dos físicos" (VI, 34), tese que ao menos deixa em aberto a possibilidade de uma abordagem científica que pudesse estudar sem distorções a fé perceptiva.
} 
filosofia reflexiva, se caracteriza por executar o movimento oposto: assimilar as relações objetivas às capacidades subjetivas. Merleau-Ponty tem em vista o idealismo radical, que converte a atividade perceptiva em um modo de pensamento e interpreta a experiência do mundo como atualização de possibilidades internas do sujeito cognitivo (Cf. VI, 48-9).

Essa conversão idealista extingue o paradoxo da fé perceptiva ao reduzir o mundo percebido a possibilidades intelectuais do sujeito cognoscente. É verdade que mesmo a filosofia reflexiva não pode negar que as coisas percebidas parecem existir de maneira autônoma, independentemente dos poderes subjetivos (o que justamente gera o paradoxo da fé perceptiva). Porém, segundo tal doutrina, essa dificuldade superficial é superada pela tese da estrita correlação entre a estrutura das coisas (e do mundo em geral) e a estrutura do pensamento humano. Por trás da ingenuidade e das confusões do sujeito empírico vigoraria a clareza do sujeito transcendental, para quem o mundo fenomênico jamais extrapola as possibilidades de seu arcabouço intelectual. Assim, sob os equívocos da fé perceptiva, a filosofia reflexiva localiza um pensamento constituinte que delimita a amplitude da experiência e justifica a certeza ingênua de se estar em contato com as próprias coisas ao defender que tais coisas jamais escapam às capacidades cognitivas humanas.

Merleau-Ponty rejeita a estratégia pela qual a filosofia reflexiva pensa resolver o enigma da fé perceptiva, e apresenta ao menos dois argumentos para tanto. No primeiro deles, o filósofo mostra que a suposição de um pensamento ordenador sob a fé perceptiva está errada; no segundo, revela como os procedimentos reflexivos dependem da atividade perceptiva, a qual, então, é fundante em relação ao pensamento, conforme veremos a seguir.

No primeiro argumento (Cf. VI, 53-4), o filósofo nota, de início, que a filosofia reflexiva pretende descobrir um pensamento constituinte da experiência, o qual seria sempre ativo. No entanto, não é possível desvelar tal pensamento constituinte, pois todo pensamento é uma modificação de uma experiência irrefletida anterior. Portanto, devese reconhecer que o pensamento não é co-extensivo com a experiência, mas posterior a ela.

Segundo esse argumento, não é correto postular um pensamento constituinte que organiza e delimita a experiência, pois desse modo se perderia um dos principais aspectos dessa última: o seu caráter irrefletido. O que caracteriza a experiência perceptiva, ao menos na descrição de Merleau-Ponty, é a sua independência de atos 
reflexivos ou pensamentos expressos ${ }^{16}$. O pensamento reflexivo nasce de um estado de ignorância inicial. Ao postular a identidade entre pensamento e experiência, a filosofia reflexiva torna incompreensível o surgimento do primeiro, um processo que pressupõe um estado irrefletido prévio.

O segundo argumento (Cf. VI. 58-9) conclui que a reflexão é dependente das estruturas perceptivas. Para tanto, Merleau-Ponty retoma o movimento argumentativo da filosofia reflexiva: trata-se de uma passagem da análise da percepção bruta para a análise do pensamento sobre a percepção. Nessa passagem, supõe-se que a coisa percebida na experiência em questão se mantenha a mesma. Essa convicção de que o conteúdo da experiência vivida permanece idêntico na reflexão sobre tal experiência se origina na atividade perceptiva. Afinal, o entrelaçamento espontâneo da duração da percepção bruta com aquela do exame reflexivo é da ordem da sensibilidade, é uma das estruturas da percepção corporal.

Nesse argumento, Merleau-Ponty mostra que a reflexão depende das virtudes da retenção temporal. E como o filósofo atribui essas virtudes à experiência corporal, fica claro que a reflexão supõe, como sua condição, a vivência irrefletida. Já havíamos notado a remissão das estruturas da temporalidade à experiência corporal ao analisar os cursos A Instituição e A Passividade, em nosso terceiro capítulo. Em $O$ Visível e o Invisível, o filósofo mantém esses resultados: é por meio das modificações do ponto de vista corporal em relação às coisas percebidas (ou seja, por meio da duração corporal) que o sujeito aprende sobre a permanência dessas (ou seja, sobre uma duração inerente às coisas) (Cf. VI, 58). E a convicção irrefletida da permanência das coisas numa duração contínua está na base do esforço intelectual de manutenção de um mesmo objeto ante o olhar reflexivo. Assim, o funcionamento da reflexão decorre de uma estrutura intencional que se enraíza na vivência do corpo.

Contra a filosofia reflexiva, Merleau-Ponty sugere uma sobre-reflexão [surréflexion] (VI, 60, 69), ou seja, uma reflexão que se mantenha atenta às modificações que ela mesma produz sobre a experiência irrefletida e que, dessa forma, reconheça a autonomia dessa última ante os procedimentos reflexivos. Era apenas por ignorar essas modificações que a filosofia reflexiva assimilava a fé perceptiva a um pensamento constituinte. Como vimos, essa assimilação é falsa, uma vez que a atividade perceptiva somente fornece o solo sobre o qual a reflexão pode se erguer.

\footnotetext{
${ }^{16}$ Essa tese já se encontra na Fenomenologia da Percepção (Cf. p.IV, IX, 75).
} 
A atividade perceptiva envolve uma mistura, difícil de ser explicada teoricamente, entre uma tese "objetiva" e uma "subjetiva". Vimos, nas duas últimas seções, que tanto a ciência quanto a filosofia reflexiva tentam submeter uma dessas teses à outra. O seu fracasso comprova a necessidade de respeitar os dois aspectos constituintes da fé perceptiva. No segundo capítulo de $O$ Visível e o Invisível, MerleauPonty analisa uma estratégia que pretende considerar a fé perceptiva em sua real complexidade: a filosofia de Sartre.

\section{A ontologia sartreana}

$\mathrm{Na}$ primeira e maior seção do segundo capítulo de $O$ Visível e o Invisível, intitulada "A fé perceptiva e a negatividade", Merleau-Ponty expõe como Sartre, principalmente em $O$ Ser e o Nada, lida com o problema da fé perceptiva. Dessa análise, bastante longa e detalhada, reproduziremos somente sua estrutura argumentativa geral, a qual é composta de três partes. Na primeira delas, consideram-se as aparentes virtudes da ontologia sartreana quanto ao tema da fé perceptiva (parágrafos três a sete do segundo capítulo). Na segunda, avalia-se o esquema lógico-conceitual dessa ontologia (parágrafos oito a doze) e, na terceira, a descrição da experiência provida por ela (parágrafos treze a quinze).

De início, Merleau-Ponty expõe como a ontologia sartreana parece preservar as características da fé perceptiva. Após definir o mundo como plena positividade (ser emsi) e desinflar a esfera da subjetividade ao concebê-la como pura negatividade (para-si), Sartre extrai algumas consequiências das relações entre esses dois pólos, as quais aparentam exprimir o conteúdo da fé perceptiva. Como o mundo é absolutamente em-si, é possível afirmar que ele existe, de maneira independente da subjetividade. No entanto, como essa é um puro nada, não subsiste sozinha e sempre está preenchida por algum aspecto ou perspectiva do ser em-si. Daí surge o mundo fenomenal, para o qual a subjetividade se abre sem nenhum intermediário. Assim, por um lado, o sujeito é estrangeiro às coisas, já que é um puro nada. Mas por outro, está destinado a elas, e só existe envolvido pelo ser, de modo a lançar-se em um mundo fenomênico segregado sobre a pura positividade e plenitude do em-si.

Essas teses parecem reproduzir a abertura para o mundo (já que o nada é consagrado ao ser) e a possibilidade de encobrimento (já que o ser é exterior ao nada), propriedades pelos quais Merleau-Ponty caracterizara a fé perceptiva. Vale notar aqui que Merleau-Ponty explicita uma outra característica da fé perceptiva, a qual Sartre 
aparentemente também teria respeitado: a abertura a um mundo intersubjetivo (Cf. VI, 83). No primeiro capítulo de $O$ Visível e o Invisível a intersubjetividade não é, ao menos de início, parte das "crenças" veiculadas pela fé perceptiva. Na verdade, ali, apela-se à intersubjetividade somente como a um recurso tardio para tentar resolver o paradoxo da fé perceptiva (Cf. VI, Cap. I, § 6-7): a presença de outrem poderia confirmar que as coisas existem como tais mesmo se limitadas aos relatos dos poderes do corpo, já que elas seriam percebidas não só por um sujeito, mas por vários. Contudo, o fato de que o sujeito A possa perceber o sujeito B em contato com as mesmas coisas que ele (A) reconhece, não resolve o caráter paradoxal da fé perceptiva, mas somente o reitera. Afinal, B é percebido por meio das estruturas corporais de A, e a mesma proximidade e distância instauradas por elas em relação ao mundo se repetem quanto a $\mathrm{B}$, mais um tema percebido que depende da fé perceptiva de $\mathrm{A}^{17}$.

Já no segundo capítulo, Merleau-Ponty admite explicitamente que o problema da fé perceptiva não se restringe ao contato entre sujeito e mundo, mas também abrange a relação entre os sujeitos: percebem-se outros sujeitos, os quais aparecem em sua existência autônoma, embora o acesso a eles seja limitado àquilo que se manifesta na experiência perceptiva.

Dissemos que em princípio Sartre também parece respeitar a experiência intersubjetiva tal como ela se manifesta por meio da fé perceptiva. De fato, é possível conceber, sob a terminologia sartreana, que diferentes subjetividades sejam preenchidas pela plenitude do em-si e se relacionem em um mundo comum. Contudo, MerleauPonty julga que Sartre não chega realmente a conceber um campo de relações efetivas entre sujeitos, mas que apenas propõe uma difícil convivência entre vários mundos privados. Ao definir cada sujeito como puro nada, Sartre implica que cada um se dirige ao ser em-si e é moldado pelas situações mundanas. Na condição de sujeitos situados, os para-sis deixam expostas a situação exterior em que cada um deles se torna reconhecível, conforme as determinações históricas e sociais do mundo. Assim, cada para-si só estabelece contato com a situação mundana que nega o puro nada constitutivo de outro para-si. Não há relação efetiva entre os sujeitos, mas somente a exibição dos aspectos situacionais passivamente cristalizados em cada para-si (Cf. VI, 99).

\footnotetext{
17 “A intervenção de outrem não resolve o paradoxo interno de minha percepção: ela acrescenta a ele esse outro enigma da propagação em outrem de minha vida mais secreta" (VI, 27).
} 
Segundo Merleau-Ponty, a experiência intersubjetiva, tal como descrita por Sartre, não acrescenta nenhum novo conhecimento aos sujeitos, ou seja, não é fonte de aprendizado sobre si próprio. Para a filosofia sartreana, a intersubjetividade ocorre principalmente por meio do olhar, o qual alcança somente os sujeitos enquanto cristalizados nas situações mundanas. Dessa maneira, o olhar apresenta outrem não como puro para-si, mas como sujeito objetivado pelas relações mundanas. Mas essa objetivação, cada sujeito a conhece interiormente, pois o preenchimento do nada pelo ser do mundo é decorrente da sua própria estrutura ontológica subjetiva. Por conseguinte, julga Merleau-Ponty, a intersubjetividade narrada por Sartre não vai além de uma confirmação empírica do envolvimento do nada subjetivo no ser mundano (Cf. VI, 99). Conforme vimos no segundo capítulo, para Merleau-Ponty a intersubjetividade fornece mais do que uma verificação de estruturas ontológicas independentes de e anteriores ao contato inter-humano. Que se considere, por exemplo, a inserção dos sujeitos no mundo por meio de suas vivências sensíveis. $\mathrm{O}$ exercício intersubjetivo da linguagem oferece as condições para que as experiências sensíveis realizem sua pretensão de validade universal. Assim, as relações intersubjetivas não apenas explicitam as estruturas ontológicas pelas quais os sujeitos se inserem em seu meio, mas compõem essas próprias estruturas de maneira indispensável.

Ao expor o tema da relação entre os para-sis, começamos a acompanhar a avaliação de Sartre por Merleau-Ponty. As limitações sartreanas quanto à intersubjetividade decorrem da sua definição de sujeito como nada e de ser como em-si, a qual já delimita de antemão as relações intersubjetivas como exteriores, ou seja, mediadas por situações mundanas em que cada para-si jamais se mostra tal como é. Esse veredicto sobre a intersubjetividade sartreana está inserido em uma avaliação global da filosofia de Sartre por Merleau-Ponty, a qual examina, em primeiro lugar, o seu esquema lógico-conceitual (Cf. VI, Cap. II, § 8-12). Acompanhemos mais de perto essa análise.

Segundo Merleau-Ponty, Sartre parte da oposição entre ser e nada, e promete um ser mais amplo (que incluiria o nada) como resultado final de sua ontologia (Cf. VI, 93). Dadas as definições iniciais do nada como ausência de propriedades e do ser como plenitude absoluta, segue-se uma relação bastante rígida entre sujeito e mundo: o primeiro se abre imediatamente para o segundo, preenchendo-se do ser, o qual, por sua vez, nega a pureza da subjetividade ao torná-la sempre situada. No entanto, a relação entre ser e nada também é bastante frágil, uma vez que ambos são opostos absolutos que 
jamais se confundem de fato. Essas relações ambivalentes entre ser e nada frustram, julga Merleau-Ponty, as pretensões sartreanas de apresentar uma noção ampliada de ser em geral. Uma vez que o ser é definido como oposto ao nada, não há passagem lógica que permita a incorporação desse último no primeiro. Seria necessário modificar as definições iniciais para obter o resultado esperado, o que Sartre não faz.

Merleau-Ponty considera uma possível objeção à sua análise: revelar a ambivalência do esquema conceitual sartreano seria insuficiente para criticá-lo, pois Sartre estaria na verdade oferecendo uma descrição da experiência (Cf. VI, 104). Quer dizer que Sartre tomaria como base para a sua filosofia certos fatos inegáveis da existência humana, de modo que seu esquema lógico-conceitual não seria senão uma decorrência da maneira como nossas vivências inevitavelmente ocorrem. A ambivalência do esquema lógico-conceitual não seria, assim, um problema, mas simplesmente a expressão da experiência, a qual, ela mesma, seria ambivalente.

Para responder a essa objeção, Merleau-Ponty passa a avaliar a qualidade descritiva da filosofia sartreana (Cf. VI, Cap. III, § 13-15). Apresentar a experiência (tal qual propõe Sartre) como relação entre um nada (exterior ao mundo) em contato direto com o ser pleno captaria somente a impressão subjetiva, gerada pela atividade visual, de se abranger o mundo inteiro pelo olhar sem se misturar com nenhum evento ou situação mundana (já que o sujeito seria algo oculto, atrás dos olhos). No entanto, essa impressão de que se pode sobrevoar o mundo sem estar nele envolvido não corresponde à totalidade da experiência visual. Merleau-Ponty defende que o exercício da visão supõe um sistema orgânico visual, o qual é visível: o sujeito vidente possui olhos, os quais estão inseridos em um corpo e funcionam de acordo com o equilíbrio sistêmico desse último em relação ao meio ambiente. Mais do que oferecer uma descrição naturalista do exercício da visão, importa a Merleau-Ponty acentuar que tal exercício supõe uma camada passiva, ou seja, supõe o corpo como massa visível. E trata-se de reconhecer que por meio dessa camada, o corpo partilha dos atributos sensíveis das coisas mundanas, tais como a visibilidade e a tangibilidade. Por conseguinte, ao se realizar por meio do corpo, a subjetividade não pode ser caracterizada como puro nada oposto ao mundo, já que ambos compartilham certas propriedades ontológicas.

Merleau-Ponty considera, a título de hipótese, que a experiência se limite àquilo que Sartre descreve. Mesmo assim, a descrição articulada em termos de relações entre em-si e para-si seria insuficiente. Afinal, se o ser fosse realmente em-si, massa plena independente da subjetividade, então não haveria como o sujeito se relacionar 
diretamente com ele, uma vez que o olhar humano sempre o apresenta como ser visto, ou seja, ser já de algum modo ligado às estruturas subjetivas. Além disso, se a consciência fosse um puro nada, ela deveria estar de tal forma preenchida pelo ser que não haveria nem mesmo espetáculo subjetivo, mas apenas uma reiteração contínua da plenitude do em-si. No entanto, o mundo é percebido de acordo com os poderes da subjetividade, os quais (conforme Merleau-Ponty considerou ao analisar a fé perceptiva) podem não esgotar toda a amplitude do ser.

Merleau-Ponty conclui da análise exposta nos dois parágrafos precedentes que a tentativa de salvar a ontologia sartreana ao caracterizá-la como descrição da experiência não funciona. O mesmo problema localizado no esquema lógico-conceitual (as limitações geradas pelas definições iniciais) reaparece no nível descritivo. Se se parte da oposição radical entre ser e nada, não se pode atingir as metas propostas, sejam elas ou uma definição mais ampla do ser ou a descrição da experiência vivida em toda a sua complexidade. Para atingi-las, Sartre deveria ter revisto o seu ponto de partida, o qual envenena todo o desenrolar da sua filosofia.

Para manter-se fiel à fé perceptiva, Merleau-Ponty sugere abandonar o esquema geral da filosofia sartreana em prol de uma descrição mais refinada da experiência. Vimos que não é possível definir a subjetividade como um nada que coincide plenamente com a visão, pois o sujeito vidente existe como corpo enredado no ser visível. Além disso, deve-se notar que o sujeito não vê o seu próprio corpo por completo, o que implica uma opacidade do vidente em relação a si próprio (Cf. VI, 107), tópico que deveria ser explorado em uma descrição do "pólo subjetivo" da experiência. Já no que concerne ao "pólo objetivo" da experiência, trata-se de defender que jamais o ser se apresenta como puro em-si. Segundo Merleau-Ponty, "o que é primeiro não é o ser pleno e positivo sobre o fundo do nada, é um campo de aparências" (VI, 109), em que o desvelamento e o encobrimento do mundo não são excludentes (Cf. VI, 106). O ser se caracteriza, assim, por uma profundidade inesgotável (Cf. VI, 107); ele não é um bloco pleno, mas um horizonte constituído de várias dimensões (tais como a sensível e a histórico-cultural [Cf. VI, 115], por exemplo), às quais o sujeito assimila apenas parcialmente.

Um sujeito opaco, que não possui experiência ou conhecimento adequados de si mesmo, e um ser profundo, que não se deixa abarcar totalmente pelo aparato perceptivo. Eis os temas anunciados por uma interrogação filosófica mais fiel à fé perceptiva, que 
não a submeta a oposições conceituais extremamente gerais, abstratas, tal como aquela entre ser e nada.

\section{A interrogação filosófica}

No final da primeira seção e em toda a segunda seção do segundo capítulo de $O$ Visível e o Invisível, Merleau-Ponty circunscreve as linhas gerais de uma investigação filosófica que explicite a opacidade do sujeito e a profundidade do ser. De início, o filósofo pondera se o termo "dialética" não denominaria o sentido de sua crítica à filosofia sartreana em nome de uma maior fidelidade à abertura e ao encobrimento que compõem a fé perceptiva. Se se define "dialética" como explicitação dos processos concretos pelos quais os temas estudados se ordenam, então esse termo bem caberia à sua empreitada. Porém, para Merleau-Ponty a "dialética" também é associada à subsunção de tais processos a leis abstratas, o que apaga a especificidade dos casos em nome de um esquema geral. Para evitar qualquer aproximação com esse último sentido, o filósofo sugere o termo "hiperdialética" (VI, 127) como marca de uma reflexão que evita as sínteses gerais e as abstrações, procedimentos por vezes associados à dialética. $\mathrm{O}$ apelo a uma hiperdialética ecoa aquele a uma sobre-reflexão. Em ambos os casos, Merleau-Ponty almeja uma análise filosófica precavida dos erros que levam a subestimar as particularidades das vivências pré-reflexivas ante o aparato conceitual reflexivo.

Acompanhemos como Merleau-Ponty explicita essa análise que pretende exceder as limitações das reflexões filosóficas tradicionais. Lembremos, conforme já apontamos no início deste capítulo, que para ele a filosofia deve retornar à experiência em que os sujeitos se encontram enredados antes de exercer a reflexão (Cf. VI, 135), e esse retorno deve ocorrer sem substituir a fé perceptiva por relações entre conceitos abstratos, como ocorreu na filosofia sartreana. Deve-se agora notar que voltar-se para a experiência não significa perguntar se o mundo por ela apresentado existe verdadeiramente, ou se se tem realmente acesso à realidade e não se está, por exemplo, limitado a um sonho bem ordenado. Esse questionamento de índole cética é explicitamente rejeitado por Merleau-Ponty. Já no primeiro capítulo de $O$ Visível e o Invisível, o filósofo o critica por dois motivos (Cf. VI, 19-21):

a) tal questionamento supõe a experiência do mundo a qual é então posta em dúvida: ao considerar a possibilidade de que todas as percepções sejam falsas, a interrogação cética generaliza algo que normalmente se reconhece em algumas percepções, a saber, o 
fato de que elas são ilusórias. Mas o procedimento para atribuir caráter ilusório (falsidade) a algumas percepções se serve, como vimos, do desenrolar concordante de várias outras percepções, as quais são consideradas verdadeiras. Assim, essa atribuição de possível falsidade a todas as percepções admite algum contato com o real, em nome do qual elas poderiam ser assim tachadas. Uma vez que o falso só pode ser definido em relação ao verdadeiro, o questionamento da totalidade da apresentação do ser por meio da percepção longe de romper o laço com o mundo depende ainda de alguma manifestação verdadeira do ser, a qual, para Merleau-Ponty, só se efetua pela fé perceptiva.

b) o questionamento cético supõe uma noção dogmática de ser em-si: a comparação das percepções com os sonhos trata ambos como estados mentais aos quais talvez nada objetivo corresponda. Percepção e sonho são definidos como atividades da interioridade psíquica, e todo o problema se resume a perguntar por sua adequação a um ser em-si, o qual se admite existir mesmo se se duvida das formas de acesso a ele. Merleau-Ponty rejeita definir a percepção como estado mental ao qual pode ou não corresponder um aspecto de um mundo em-si. Em sua descrição da fé perceptiva, uma das principais características da atividade perceptiva é a abertura efetiva para o mundo, para as coisas.

No segundo capítulo de $O$ Visível e o Invisível, Merleau-Ponty apresenta mais uma ressalva contra a interrogação cética (Cf. VI, 128-9):

c) o questionamento cético admite uma noção obscura de existência: a pergunta pela distinção entre a existência do mundo e um sonho bem ordenado supõe que o sonho exista de algum modo; na verdade, questiona-se, à luz dessa existência do sonho, se o mundo seria tal como aparece. Mas o modo de existência do sonho (ou de qualquer instância utilizada para problematizar o acesso perceptivo ao mundo) permanece obscuro. Não se sabe, por exemplo, se ele implica ou não a autonomia de um reino psíquico em relação ao mundo exterior. Seria preciso esclarecer o sentido desse modo de existência para então avaliar se ele comporta o uso que o cético dele faz.

Dadas essas dificuldades do questionamento cético, Merleau-Ponty o rejeita como modelo para a interrogação filosófica. A meta de tal interrogação não é, por conseguinte, questionar se o mundo é, mas sim revelar o que ele é. Vimos que o questionamento cético supõe um contato tácito com o mundo. A interrogação filosófica buscada por Merleau-Ponty expõe esse pressuposto e torna esse laço entre sujeito e mundo, o qual é mantido pela fé perceptiva, o tema da sua análise. 
Merleau-Ponty enumera ao menos três características dessa interrogação que se volta para experiência pré-reflexiva. A primeira delas é que por não buscar preencher uma incógnita delimitada, mas sim explicitar a manifestação do mundo pela fé perceptiva, a interrogação filosófica se difere daquelas cotidianas tais como "que horas são?", “onde se localiza a cidade de Socorro?”, e mesmo daquelas científicas (“como funciona o mecanismo Y?”, quais os componentes do processo Z?"). As questões cotidianas ou científicas são respondidas pela circunscrição de aspectos de um objeto ou fato específico. Já a questão filosófica não investiga entes determinados, mas sim o ser anterior a toda objetivação (Cf. VI, 135). No curso "A filosofia hoje" (1958-1959), Merleau-Ponty explicita um pouco mais qual o sentido de se dirigir a esse ser préobjetivo. Ali, o filósofo afirma que a interrogação filosófica implica uma "consideração do todo e de suas articulações" (NC, 37). Eis a razão pela qual a filosofia não busca circunscrever incógnitas delimitadas: importa investigar a experiência humana e o ser do mundo, do qual ela se erige, em sua totalidade. Não se trata assim de analisar fatos ou situações particulares, mas sim de esclarecer as noções mais gerais pelas quais se reconhecem os fatos e por meio das quais eles são classificados em categorias diversas.

A segunda característica é que a problemática filosófica subjaz ao questionamento do senso comum. Normalmente, as pessoas se satisfazem, por praticidade, com respostas simples às questões cotidianas (sobre as horas ou a localização, etc.), uma vez que os dados das respostas servem somente como instrumento na realização de compromissos ou na manutenção do bem-estar. Não há necessidade de interrogar a natureza do tempo toda vez que se pergunta pelas horas, pois o que se quer saber, na maior parte dos casos, é apenas um dado específico, que auxilia na realização de um fim já delimitado anteriormente. Contudo, esses hábitos pragmáticos não aniquilam o caráter enigmático da experiência do tempo e do espaço. Segundo Merleau-Ponty, é a interrogação filosófica que desvela esses enigmas, interrogação subjacente àquelas cotidianas, já que essas poderiam ser desdobradas até expor os enigmas da existência (Cf. VI, 138-9). Suponhamos, a título de exemplificação, que alguém não se contente com uma resposta pontual (14:30h, por exemplo) a uma pergunta sobre as horas, e questione então como se chega a tal saber. Isso exige a retomada de um arsenal de conhecimentos mais vasto, acerca da segmentação do tempo que a Terra leva para girar em torno de si mesma de maneira a compor, assim, um dia solar. Mesmo após tal resposta, inúmeras questões ainda são possíveis: se em um suposto planeta sem rotação os seus habitantes teriam alguma 
noção de hora; se a noção do tempo, pela qual se definem as horas, depende daquela de movimento; qual noção de tempo poderia haver sem nenhum movimento planetário; e assim por diante. Esse exemplo simples explicita que o tipo de interrogação pelo qual a filosofia se caracteriza para Merleau-Ponty (interrogação que não supõe dado nenhum contexto com base no qual se delimita uma incógnita, mas que questiona a origem de todos os contextos) jaz sob as indagações mais banais.

No terceiro capítulo de $O$ Visível e o Invisível, Merleau-Ponty explicita a terceira característica da questão filosófica: a auto-referencialidade. A interrogação filosófica não se dirige apenas para temas gerais, mas também para si mesma como questão (Cf. VI, 157). Quer dizer que os modos pelos quais o filosofar se realiza não estão todos definidos de antemão, mas também são problematizados à medida que se cumprem. Essa autoproblematização da filosofia se torna aparente quanto ao tema da linguagem, como veremos a seguir ${ }^{18}$.

\section{A linguagem da filosofia}

A interrogação filosófica é um procedimento lingüístico que, como bem formula Merleau-Ponty, se dirige para "essa mistura do mundo e de nós que precede a reflexão" (VI, 136). Há algo de paradoxal nessa empreitada. Afinal, trata-se de questionar a experiência muda, a qual não pode, diretamente, oferecer nenhuma resposta. Na verdade, toda resposta obtida será construída pela própria filosofia, o que parece indicar que não se atingiu verdadeiramente a experiência pré-reflexiva. Emile Bréhier já havia notado um problema semelhante na palestra ministrada por Merleau-Ponty à Sociedade Francesa de Filosofia em 1946: o retorno à experiência imediata parece exigir o silêncio da parte do filósofo, já que a expressão filosófica implicaria trair o mutismo constitutivo de tal experiência (Cf. PP, 77).

Merleau-Ponty alegara naquela ocasião que não propunha uma fusão com a experiência imediata pura, mas sim a compreensão do âmbito antepredicativo por meio do aparato crítico e expressivo (Cf. PP, 77). Não haveria, assim, problema em admitir que a experiência vivida só pode ser levada em conta após sua tradução lingüística. Contudo, não ficava claro, na solução exposta em 1946, como a experiência antepredicativa poderia ser respeitada ao ser tratada predicativamente pela filosofia. Em O Visível e o Invisível, Merleau-Ponty esclarece esse tópico ao defender que a questão

\footnotetext{
18 Tal como o filósofo afirma em uma nota de trabalho: "a definição da filosofia comportaria uma elucidação da própria expressão filosófica” (VI, 219, jan. 1959).
} 
filosófica: a) não é um exercício lingüístico independente do ser do mundo, e b) que as respostas por ela fornecidas não se compõem de definições estipulativas ou convencionais, as quais seriam totalmente arbitrárias em relação à experiência vivida.

Quanto ao primeiro ponto, notemos que, para Merleau-Ponty, o próprio mundo se caracteriza como interrogativo ${ }^{19}$. O filósofo parece sugerir que o mundo interpela os sujeitos e os leva a verbalizar as interrogações filosóficas. Esse processo seria reconhecível, por exemplo, na experiência da admiração: algum evento ou coisa rompe as expectativas subjetivas formadas com base na regularidade cotidiana e fomenta um questionamento acerca das características do ser para além dos padrões de repetição de fenômenos já assimilados pelo agir instrumental ${ }^{20}$. Assim, o questionamento filosófico, tal como apresentado por Merleau-Ponty, não seria uma iniciativa plenamente voluntária, decorrente apenas do exercício das habilidades cognitivas humanas. $\mathrm{Na}$ verdade, a questão filosófica verbaliza enigmas que o próprio ser dirige ao sujeito.

Quanto ao segundo ponto, Merleau-Ponty defende que a questão filosófica não é solucionada por definições artificiais. A linguagem filosófica, tal como já vimos no segundo e quarto capítulos, deve se exercer como atividade criadora que explicita as articulações do mundo sensível, sem substituí-las por um jogo entre conceitos abstratos (Cf. VI, 136-7). O uso criador da linguagem exibe, em sua própria estrutura, o modo como o ser do mundo se ordena. Afinal, a linguagem não é concebida por MerleauPonty como simples tradução de pensamentos claros, e sim como um processo mais amplo que aqueles pertencentes à consciência cognitiva, o qual se realiza por meio do sujeito, mas não é constituído por $\operatorname{ele}^{21}$. A linguagem filosófica não só diz ou veicula proposicionalmente o excesso do ser em relação ao aparato cognitivo humano, mas também mostra nas próprias formas do discurso a complexa ordenação ontológica do real. Nos últimos textos de Merleau-Ponty, é visível o abandono progressivo de conceitos clássicos (sujeito, objeto, relação, etc.) em prol de termos figurativos ou metafóricos (turbilhão, quiasma, carne, reversibilidade, etc.), os quais, longe de exercer

\footnotetext{
19 “A filosofia interroga a fé perceptiva, - mas não espera nem recebe uma resposta no sentido ordinário, (...) porque o mundo existente existe sob a forma interrogativa" (VI, 137). "O interrogativo não é um modo derivado por inversão ou troca do indicativo e do positivo (...), mas uma maneira original de visar algo, por assim dizer, uma questão-saber, que não pode por princípio ser ultrapassada por nenhum enunciado ou 'resposta', talvez, por conseguinte, o modo próprio de nossa relação com o Ser, como se ele fosse o interlocutor mudo ou reticente de nossas questões" (VI, 168-9).

${ }^{20}$ Seguimos aqui a interpretação de Martin Gagnon. Cf. "Étonnement et interrogation - Essai sur Merleau-Ponty”. In: Revue Philosophique de Louvain, Vol. 93, n.3, 1995, p.370-391.

21 "A linguagem nos tem e (...) não somos nós que temos a linguagem. (...) é o ser que fala em nós e não nós que falamos do ser" (VI, 244, maio 1959).
} 
mera função ilustrativa, aproximariam o pensamento das estruturas do $\operatorname{ser}^{22}$. Não se trata, certamente, de buscar termos que melhor coincidam com a experiência, ou seja, termos cujo conteúdo veiculasse adequadamente os eventos em questão ${ }^{23}$. Trata-se, antes, de exibir, pelo recurso à pluralidade de metáforas e à multiplicidade de descrições, que a realidade rejeita definições unívocas e envolve latências para além das manifestações atuais, envolve uma profundidade que alimenta diferentes configurações fenomênicas que se sucedem sem esgotar a complexidade do ser. É essa latência ou profundidade (não exprimível tal qual os conteúdos positivos da experiência) a que a linguagem filosófica deve aludir ${ }^{24}$.

\section{O problema das essências}

O questionamento filosófico deveria exprimir, não só pelo seu conteúdo, mas pela sua própria forma, a inesgotabilidade de um ser opaco às estruturas perceptivas subjetivas. Não se trata, assim, de conceber a investigação filosófica como mera formulação de definições que pretensamente resolveriam os enigmas da existência humana seriam resolvidos. Os problemas filosóficos gerais não admitem, julga MerleauPonty, respostas definitivas, já que aquilo mesmo que é questionado (em última instância, o ser do mundo) jamais se desvela totalmente e, por conseguinte, não poderia se esgotar nas descrições ou classificações pontuais propiciadas pelo discurso declarativo. Cabe à filosofia encontrar meios de exprimir essa negatividade inerente ao ser, ou seja, exprimir o excesso do ser em relação a todos os fatos, assimiláveis pelo sujeito perceptivo. Na seção seguinte, veremos algumas noções forjadas por Merleau-

\footnotetext{
${ }^{22}$ Cf. Saint-Aubert, E. Du Lien des Êtres aux Éléments de l'Être. Merleau-Ponty au tournant des années 1945-51. Paris : Vrin, 2004, Introdução.

${ }^{23}$ Cf. Tréguier, J. M. Le Corps selon la Chair. Paris: Kimé, 1996, segunda parte - O método do discurso.

${ }^{24} \mathrm{Um}$ recurso lingüístico usado por Merleau-Ponty para salientar essa latência do ser é, em vez da invenção de conceitos, a exploração do sentido de termos da linguagem comum (por exemplo, carne e entrelaçamento), por meio dos quais o filósofo explicita relações ontológicas inaparentes, que não são captadas pelo arcabouço conceitual da tradição filosófica (Cf. Saint-Aubert, E. Du lien..., Introdução). Segundo N. Depraz, esses termos, conforme usados por Merleau-Ponty, "possuem a estranha ressonância conjugada do abstrato e do concreto, como certas alegorias em busca de uma concretização do abstrato. (...) O conceitual, longe de ser abolido, encontra seu impulso e seu rejuvenescimento nos recursos oferecidos pelas palavras que são mais concretas" (Depraz, N., "Selon quels critères peut-on definir une écriture phénoménologique?". In: VV. AA. Merleau-Ponty et le littéraire. Paris: Presses de l'École Normale Supérieure, 1997, p.51). Um bom caso dessa expressão concreta de relações que escapam às categorias abstratas tradicionais ocorre com o termo "quiasma". Esse termo, que normalmente indica cruzamento de tecidos (sentido biológico) ou uma série de termos que se espelham num paralelismo invertido (ABCD : D'C'B'A', e. g.; eis o sentido retórico dessa palavra), é utilizado por Merleau-Ponty para comentar, por exemplo, as relações entre o corpo percipiente e o mundo sensível: a sensibilidade inerente ao mundo é espelhada de maneira invertida pelo corpo, o qual, então, não só é sensível, mas também senciente.
} 
Ponty para captar ao menos algumas propriedades desse ser primordial (por exemplo, a caracterização do ser não como somatória de fatos, mas como um conjunto de membranas ou estilos gerais que envolvem e possibilitam a ordenação dos fatos mundanos). Antes, porém, acompanhemos como no terceiro capítulo de $O$ Visível e o Invisível Merleau-Ponty rejeita que a investigação filosófica se limite a buscar essências, quer dizer, entidades puramente intelectuais que exprimiriam as propriedades responsáveis por uma definição necessária de algum fato ou evento em questão ${ }^{25}$. Assimilar a investigação filosófica à busca de essências seria como que um refinamento da concepção de filosofia como formulação de definições rigorosas e unívocas. Nesse último caso, as definições obtidas poderiam implicar distinções arbitrárias ante a complexidade do ser do mundo, tal como vimos na subseção passada. $\mathrm{O}$ apelo às essências garantiria então que as definições e distinções obtidas apreendem necessariamente o conteúdo estudado.

Para Merleau-Ponty, as essências não são uma resposta adequada à interrogação filosófica. A investigação acerca do ser primordial do mundo não poderia se completar pela explicitação de essências, pois o saber de que há um mundo não é dado por elas, e sim pela fé perceptiva ${ }^{26}$. Além disso, a formulação de essências decorre do poder subjetivo de variar, por recurso à imaginação, alguma experiência concreta, a fim de desvelar seus componentes definidores (Cf. VI, 147). Esse poder subjetivo depende do bom funcionamento das capacidades cognitivas, as quais, por sua vez, remetem à história pessoal, às condições fisiológicas, enfim, às vivências factuais de cada indivíduo. Assim, seja quanto ao seu conteúdo seja quanto ao método de obtê-la, a essência é dependente da experiência sensível e não pode, portanto, servir de resposta última à interrogação filosófica sobre tal experiência.

Merleau-Ponty considera a seguinte objeção à sua análise: embora o acesso às essências dependa de fato de fatores sensíveis, por princípio dever-se-ia defini-las como puros entes inteligíveis (Cf. VI, 149). As essências valeriam, assim, como reguladores

\footnotetext{
${ }^{25}$ Ao atacar tal posição, Merleau-Ponty não confronta diretamente a noção de essência defendida por Husserl, a qual, conforme o filósofo francês já mostrara em outros textos (Cf. PhP, IX-XII; PPE,411-12), supõe um contato prévio com os fatos e mesmo a reformulação do seu conteúdo conforme particularidades encontradas na experiência. Em $O$ Visível e o Invisivel, Merleau-Ponty volta a afirmar o caráter pouco dogmático da formulação de essências pelo filósofo alemão: "o próprio Husserl não obteve uma só Wesenschau que não tenha em seguida retomado e retrabalhado (...), de modo que seria ingênuo procurar a solidez em um céu de idéias ou em um fundo de sentido" (VI, 153). Assim, ao criticar a noção de essência como ente intelectual puro, Merleau-Ponty tem em vista uma certa interpretação vulgar da doutrina husserliana, mas não essa própria doutrina.

26 "O ser da essência não é primeiro, não repousa sobre si próprio; não é ele que pode nos ensinar o que é o Ser" (VI, 145).
} 
de um processo de idealização (quer dizer, de busca de traços necessários para além da multiplicidade casual da experiência), o qual, dadas nossas condições fácticas, é sempre imperfeito. Aqui, o suposto objetor cinde o nível dos fatos daquele da pureza inteligível, e sugere que esse último é o verdadeiro portador do sentido do primeiro. Neles mesmos, os fatos seriam apenas indivíduos isolados; a sua compreensão como exemplos de certos tipos de eventos (ou seja, o desvelamento de sua estrutura inteligível) dependeria de um apelo à essência de que tais fatos são meros casos, essência que, embora nunca seja apreendida em sua perfeição, permitiria discriminar os aspectos gerais de cada experiência factual.

A fim de replicar a tal objeção, Merleau-Ponty expõe e critica o pressuposto da separação entre fatos e essências puras. Apenas se se supõe um sujeito puramente intelectual, livre das amarras do sensível e capaz de contemplar do exterior a ordem dos eventos, é que se pode conceber uma essência pura, responsável pela inteligibilidade dos eventos mundanos, os quais, na realidade factual, estariam dispersos. Tal essência seria o "objeto" apreendido por um sujeito purificado do sensível. Merleau-Ponty rejeita que se possa conceber um sujeito assim; para o filósofo, tal como já apontamos, a subjetividade humana se realiza pelo corpo, o qual partilha de certas propriedades das coisas. Como elas, o corpo é um ente visível, tangível, e essa comunidade ontológica implica que o corpo (e a subjetividade, que por meio dele existe) faz parte do mundo sensível e não pode, portanto, se definir como puro poder de contemplação.

Dada a impossibilidade de um sujeito puro, não há, por conseguinte, poder subjetivo capaz de atingir uma essência pura, e essa não realiza nenhuma função organizadora da experiência humana. É verdade que ainda seria possível postular as essências puras como entidades pertencentes a uma ordem inteligível, a uma realidade aquém da compreensão humana. No entanto, além de absolutamente inverificável, tratar-se-ia de uma hipótese desnecessária para compreender a organização da experiência. Lembremos que ao postular as essências puras, o objetor pensava desvelar certos núcleos inteligíveis por meio dos quais os fatos dispersos da experiência seriam então reunidos em espécies e gêneros. Entretanto, para Merleau-Ponty, a experiência não é uma aglomeração desordenada de fatos. Com efeito, o filósofo admite que algo como "idéias" forma a textura da experiência, mas não se trata de entidades pertencentes a uma ordem diferente da facticidade (Cf. VI, 157). O filósofo se refere a agrupamentos espontâneos de fatos, os quais indicam haver já na experiência certos 
estilos gerais que funcionam como que uma idealidade primitiva, a qual, do interior do próprio sensível ordena os eventos mundanos (Cf. VI, 151-2).

Uma das principais tarefas da ontologia final esboçada por Merleau-Ponty é descrever essa inteligibilidade inerente ao mundo. Sem dúvida, trata-se, assim, de tentar cumprir a prometida "reabilitação ontológica do sensível” (S, 210), já antevista nos últimos trabalhos de Husserl, os quais apontavam para uma camada de fenômenos cujo sentido não derivava dos atos constituintes da subjetividade, mas formava uma base necessária para o exercício de tais atos. Uma vez que se reconhecem princípios gerais de ordenação inerentes ao mundo sensível, então as manifestações fenomênicas não devem ser apresentadas como eventos separados do sentido (o qual seria atribuído somente pelas funções da inteligência) e nem como meros índices verificadores da existência de eventos e coisas, cujas qualificações eidéticas só poderiam ser determinadas pelo exercício intelectual. Carlos Alberto R. de Moura cita essas duas características rejeitadas por Merleau-Ponty (o sensível como apartado do sentido e como mera instância de verificação de uma realidade que não explicita suas qualificações por meio da experiência) como parte da concepção moderna (partilhada, por exemplo, por racionalistas e empiristas do século XVII) que minimiza a relevância ontológica do sensível, uma vez que, no geral, esse era concebido somente como signo de uma realidade que, em si mesma, não se doaria à sensibilidade humana ${ }^{27}$. A reabilitação ontológica do sensível pretendida por Merleau-Ponty, embora não reduza o ser àquilo que é percebido, atribui sentido e ordenação espontânea à camada sensível do ser. O reconhecimento das dimensões invisíveis e idéias sensíveis, conforme analisamos no quarto capítulo, exemplifica o esforço de atribuir uma inteligibilidade inerente ao mundo sensível, a qual torna dispensável o apelo a um reino de puras essências como portador do sentido da experiência.

No final do terceiro capítulo de $O$ Visível e o Invisível, Merleau-Ponty sustenta que a explicitação filosófica da inteligibilidade inerente ao ser sensível não é fusão ou coincidência com a experiência do mundo ${ }^{28}$. Na verdade, essa idéia de coincidência

27 Cf. Moura, C. A. R. de, "Entre fenomenologia e ontologia: Merleau-Ponty na encruzilhada". In: Racionalidade e Crise. SP: Discurso e UFPR Ed., 2001, p. 271-293.

${ }^{28}$ Merleau-Ponty reconhece que Bergson propõe um tipo de retorno à experiência da duração, mas esclarece que ao criticar a idéia de fusão não se refere a tal filósofo, o qual teria proposto somente uma coincidência parcial com o real (Cf. VI, 165), mediada pela linguagem (Cf. VI, 163). No geral, pode-se afirmar que no terceiro capítulo de $O$ Visível e o Invisível Merleau-Ponty não critica diretamente Husserl e Bergson, mas parece atacar interpretações distorcidas da fenomenologia e do bergsonismo, quer dizer, os mitos teóricos (essências inteligíveis e coincidência total) que se criam injustificadamente em torno de tais doutrinas. 
gera um dilema insolúvel: $o u$ há a experiência imediata como tal, mas então não poderia ocorrer sua expressão filosófica (já que essa implica o uso da linguagem, a qual se interpõe entre o imediato e a consciência do filósofo) ou há a expressão filosófica do imediato, mas então esse último nunca se doa como tal (já que a expressão só pode oferecer uma reconstrução da experiência) (Cf. VI, 160-1). Para escapar de tal dilema, o filósofo defende, como vimos, um uso especial das operações lingüísticas, de modo a exibir não só pelo conteúdo, mas pela forma do discurso filosófico a inesgotabilidade do ser, o qual não é um depósito de coisas inertes, mas um processo de diferenciação de dimensões por meio das quais os eventos mundanos se ordenam ${ }^{29}$.

No próximo capítulo, exporemos com mais detalhes como o tema da invisibilidade substancia aquele das dimensões ou essências inerentes ao sensível. Por ora, bastou-nos acompanhar de que maneira, mediante a crítica de várias doutrinas, Merleau-Ponty explicita a organização espontânea do mundo sensível. Essa tarefa, que em seus termos gerais repete aquela da Fenomenologia da Percepção, revela sua originalidade por tentar respeitar não só a abertura para o mundo propiciada pela fé perceptiva, mas também o encobrimento do ser. Vejamos a seguir como Merleau-Ponty tenta elaborar de maneira positiva os dados fornecidos pela fé perceptiva. Acentuaremos primeiramente o desenvolvimento de noções acerca da abertura para o mundo, e deixaremos a análise acerca do encobrimento para o final desse capítulo e para o próximo.

\section{C) A base ontológica da fé perceptiva}

\section{A reversibilidade}

Merleau-Ponty iniciou $O$ Visível e o Invisível com uma exposição da fé perceptiva, ou seja, das "opiniões" transmitidas espontaneamente pela experiência préobjetiva. Aparentemente, tratava-se de uma retomada das descrições fenomenológicas da consciência pré-reflexiva, realizadas pela Fenomenologia da Percepção. Porém, defendemos que a fé perceptiva não é equivalente a tal consciência, uma tese que explicitaremos um pouco mais ao analisar alguns tópicos contidos no quarto capítulo de O Visível e o Invisível.

Nesse capítulo, "O entrelaço, o quiasma", o enigma de nosso contato perceptivo com o mundo é finalmente abordado de maneira positiva. De um modo geral, os três

\footnotetext{
29 "O originário se cliva e a filosofia deve acompanhar essa clivagem, essa não-coincidência, essa diferenciação” (VI, 163).
} 
primeiros capítulos serviram para delimitar o exercício da interrogação filosófica por contraste com várias tentativas fracassadas de resolver o paradoxo da fé perceptiva. Já no quarto capítulo, Merleau-Ponty exerce tal interrogação de maneira a tornar compreensível o contato perceptivo dos sujeitos com o mundo. Segundo os dados da fé perceptiva, o mundo apresentado pelos sentidos parece repousar em si mesmo, independentemente da subjetividade, e, no entanto, tudo o que dele se sabe procede de estruturas perceptivas, as quais, conforme o filósofo admitiu no primeiro capítulo de $O$ Visível e o Invisível, podem ocultar o ser e não somente revelá-lo. Como é possível então o mundo doar-se como tal mesmo se se está limitado a estruturas subjetivas? O problema filosófico da fé perceptiva é conciliar esses dois aspectos contrários (a existência independente do mundo e o fato de que tudo o que dele se sabe, mesmo sobre sua independência em relação aos sujeitos, depende das estruturas perceptivas), que coexistem harmonicamente na experiência.

A exposição das teorias que falharam em compreender a fé perceptiva ajuda Merleau-Ponty ao menos a debuxar um formato geral do que ele crê ser o exercício correto da reflexão filosófica: retorno à experiência por meio de uma expressão lingüística criadora, que exibe a organização complexa do ser. O filósofo rejeita os procedimentos reflexivos que resolvem de maneira artificial o paradoxo da fé perceptiva, e tenta explicitar pelo uso de novas noções o mecanismo tácito da atividade perceptiva, no qual jaz o segredo do equilíbrio entre um mundo que não depende de estruturas perceptivas para existir e que existe, ao menos parcialmente, tal como essas estruturas o apresentam.

Vimos que Merleau-Ponty rejeitou as respostas extremas ao enigma da fé perceptiva: o objetivismo (o mundo é um agregado de objetos absolutamente determinados e independentes do sujeito) e o subjetivismo (há um sujeito pensante que reduz tudo aquilo que existe àquilo que se conforma às estruturas intelectuais). Essas concepções inviabilizavam a própria noção de experiência, a qual parece envolver uma mistura de objetividade (de um ser independente do sujeito) e subjetividade (de uma atividade exploratória sobre o ser). Atribuir toda importância a um desses aspectos em detrimento do outro implica destruir o delicado equilíbrio da experiência: o objetivismo anula toda contribuição subjetiva à essa última, como se ela se reduzisse a um efeito direto das condições exteriores ${ }^{30}$. Já o subjetivismo ignora que o sujeito não é um puro

\footnotetext{
${ }^{30}$ Em muitos momentos de sua obra, Merleau-Ponty considera, contra essa perspectiva, o fato de que as propriedades do campo fenomenal não são redutíveis àquelas dos estímulos objetivos, o que indica, por
} 
poder de contemplação, e que, como sujeito encarnado, faz parte do mundo sensível sobre o qual se volta.

O objetivismo e o subjetivismo são doutrinas construídas sobre a fé perceptiva, mas que não respeitam sua complexidade. Para Merleau-Ponty, há uma ontologia implícita à essa fé, uma certa decodificação do ser, que, uma vez explicitada, tornará compreensível o aspecto paradoxal da atividade perceptiva e tornará dispensáveis essas doutrinas parciais. A fim de iniciar a exposição da ontologia subjacente à fé perceptiva, o filósofo explora a tese de que o corpo faz parte do próprio sensível desvelado pelos poderes perceptivos. Segundo tal tese, o corpo é um ente visível e tangível que se volta para o mundo, o qual se compõe de aspectos visíveis e tangíveis (Cf. VI, 180). Dado que o corpo é semelhante às coisas sobre as quais se volta, segue-se que as suas estruturas (que possibilitam a experiência) não são somente subjetivas, mas também partilhadas pelo mundo. Por conseguinte, a experiência não é um impeditivo para a afirmação de que o mundo existe tal como é, pois as estruturas corporais que sustentam tal experiência são semelhantes àquelas pelas quais o mundo se organiza (visibilidade, tangibilidade, por exemplo). As estruturas “subjetivas” fazem parte do ser do mundo e não poderiam, portanto, impedir que o sujeito tenha acesso àquilo mesmo de que emerge. O corpo nunca pode estar completamente separado do ser, nunca pode isolar-se somente em ilusões, pois também é esse mesmo ser, também é visibilidade, sensibilidade, as quais, por uma reversibilidade inerente à constituição corporal, voltam-se para o mundo como capacidade ativa de vidência, de tato e, no geral, de senciência.

O parentesco íntimo entre corpo e mundo impede a redução da atividade perceptiva a um evento da interioridade psíquica talvez cortado do mundo real, ou seja, impede o ceticismo radical em relação ao contato pré-reflexivo com o mundo, e torna legítima a tese de que é o próprio ser (ao menos suas camadas sensíveis) aquilo que o corpo apreende. Os dois aspectos da fé perceptiva (apresentar o próprio mundo por meio de capacidades subjetivas) deixam de ser paradoxais uma vez compreendida a comunidade genética entre corpo e mundo ${ }^{31}$. O corpo é o local em que ocorre um notável enrolamento do sensível sobre si mesmo, em que a passividade sensível se torna

conseguinte, que há um processo de organização dos dados que se sobrepõe à causalidade linear entre estímulo e resposta (Cf. SC, 207, PhP 14, PPE, 431).

31 "O corpo nos une diretamente às coisas por sua própria ontogênese, soldando (...) a massa sensível que ele é e a massa do sensível onde ele nasce por segregação, e para a qual, como vidente, ele permanece aberto" (VI, 177). 
atividade senciente. A experiência não é senão essa reversibilidade em ação: os poderes sencientes do corpo se abrem para um ser do qual ele também faz parte ${ }^{32}$.

Deve-se notar, entretanto, que a reversibilidade entre sensível e senciente não se realiza nas coisas, as quais são apenas sensíveis. É verdade que Merleau-Ponty parece atribuir senciência ao mundo, quando, ao comentar a experiência de alguns pintores, afirma que "vidente e visível se mutuam reciprocamente e que não se sabe mais quem vê e quem é visto" (VI, 181). Mas, de fato, o que o filósofo pretende acentuar, e para isso usa o exemplo dos pintores, é que uma das características do sentir é um grau de passividade em relação aos objetos sobre os quais a atividade senciente se exerce. Merleau-Ponty explicita essa característica ao examinar a experiência do tato, na qual distingue três níveis constituintes do sentir, os quais também seriam encontrados na visão (Cf. VI, 174-5) ${ }^{33}$ :

a) há um tocar do liso e do rugoso (apreensão das qualidades táteis), o qual corresponderia, na visão, à apreensão de cores e formas;

b) há um tocar das coisas sobre nós, um sentimento passivo do corpo, como se esse fosse também tocado por elas. Essa é a característica que, no caso da visão, discutíamos há pouco quanto ao exemplo dos pintores. Será que ela implica haver uma visão das próprias coisas que revelaria a passividade da visão humana? Na verdade, não se trata de atribuir vidência aos objetos visíveis, mas somente de esclarecer que o sujeito também é um ente visível aberto a outras visões possíveis, tal como ainda discutiremos mais adiante.

c) há um tocar do tocar (uma mão pode apalpar a outra), o qual nunca é perfeito, uma vez que uma mão, ao ser tocada pela outra, deixa de ser tocante e, dessa forma, nunca há coincidência total entre as duas mãos como órgãos ativos (Cf. VI, 191-2). Em relação à atividade visual, essa terceira característica corresponde à impossibilidade de que a visão se apreenda diretamente como ativa. Há uma auto-referência indireta do sujeito vidente, o qual por intermédio de espelhos (ou de outros tipos de superfícies que reflitam a luz), acompanha o próprio movimento dos olhos. No entanto, os olhos são

\footnotetext{
32 Vale notar que com essa doutrina da reversibilidade, Merleau-Ponty oferece uma justificativa ontológica para o acordo entre o conteúdo perceptivo e as estruturas mundanas. Na Fenomenologia da Percepção, como atestamos em nosso primeiro capítulo, apenas se assumia haver um pacto natural entre corpo e mundo, segundo o qual ocorre a feliz coincidência de que a lógica pela qual os eventos mundanos se desenrolam é exatamente a lógica pela qual os poderes perceptivos apreendem seus dados. Não havia, naquele livro, nenhuma tentativa de esclarecer quais as condições para que tal pacto se estabeleça, justamente o que o tema da reversibilidade oferece.

${ }^{33}$ Merleau-Ponty não menciona se a audição, o olfato e o paladar são assim constituídos.
} 
apreendidos, nesse caso, como algo visível que se move (e não como a própria capacidade vidente).

Retornemos à segunda característica, o sentimento de passividade do corpo ante o objeto sobre o qual as capacidades ativas se exercem. Não há problema, quanto ao tato, em admitir que a coisa tocada exerce como que um toque sobre a mão tocante: trata-se da resistência aos movimentos exploratórios oferecida pelos entes materiais, a qual obriga o sujeito a se reconhecer como tangível. A dificuldade surge em relação à visão, pois poder-se-ia julgar necessário que as coisas realmente observassem o sujeito para que a visibilidade fosse atribuída a esse último, o que não é verdadeiro. Trata-se somente de defender que a atividade visual implica uma passividade no sentido de que o vidente também poderia ser observado do ponto de vista daquilo que é visto, mas não que ele realmente seja observado dali. Para Merleau-Ponty, o exercício da visão implica que "um outro me veria, instalado no meio do visível" (VI, 175). Esse é o sentido da passividade sensível no caso da visão. Não se trata, portanto, de atribuir senciência à paisagem vista, mas apenas de acentuar que o sujeito vidente assume ante ela um ponto de vista em princípio visível, que ele sofreria a vidência de um outro sujeito ali localizado ${ }^{34}$.

\section{A carne}

Vimos que a reversibilidade entre as dimensões senciente e sensível da existência encarnada, e a comunidade entre essa última e as propriedades sensíveis do ser, esclarecem a apresentação do mundo pela fé perceptiva. Notemos agora que Merleau-Ponty oferece uma resposta semelhante ao problema da percepção de outrem: a generalidade sensível do mundo é partilhada por vários corpos humanos sencientes/sensíveis, os quais se reconhecem mutuamente porque, ao menos nesse nível geral, não estão plenamente separados ${ }^{35}$. Segue-se que as vivências sensíveis de outrem não são totalmente inacessíveis, uma vez que a atividade perceptiva de todos os sujeitos depende de estruturas típicas de sensibilidade, as quais embora não coincidam plenamente (como os casos de daltonismo facilmente explicitam quanto à visão, por

\footnotetext{
${ }^{34}$ Concordamos com a interpretação desse tema por M. C. Dillon, para quem os objetos visíveis "definem um ponto de vista sobre [o sujeito] que torna visível para ele algo que de outra maneira permaneceria invisível - seu fora, sua fisionomia, sua presença carnal" (Dillon, M. C. Merleau-Ponty's Ontology. Ed. supra, p.161-2).

35 "Não há aqui problema do alter ego porque não é o $e u$ que vê, não é ele que vê, e porque uma visibilidade anônima nos habita a ambos, uma visão em geral, em virtude dessa propriedade primordial que pertence à carne de, estando aqui e agora, irradiar-se a todo lugar e para sempre; de, sendo indivíduo, ser também dimensão e universal" (VI, 185).
} 
exemplo), desvelam ao menos operações gerais concordantes dos corpos em direção ao mundo (a visão, a audição, etc.). Essas operações circunscrevem vivências subjetivas que, em grande medida, são intercambiáveis entre os sujeitos. Isso ocorre porque há uma reversibilidade entre os sujeitos, os quais trocam os papéis ativo/passivo seja no toque (ao tocar o sujeito B, o sujeito A também se reconhece tocado por B, e vice versa), na visão (o sujeito A vê e é visto por B, e vice versa) ou no diálogo (em que A e $\mathrm{B}$ alternam os papéis de falante e ouvinte ${ }^{36}$ ). Essa partilha das vivências reversíveis entre os sujeitos implica que a experiência sensível não é somente um evento privado. Merleau-Ponty a define como "retorno sobre si do visível, aderência carnal do senciente àquilo que é sentido e deste ao senciente" (VI, 185). A experiência supõe, tal como já vimos no terceiro capítulo, uma sensibilidade geral do mundo, a qual alimenta diferentes perspectivas individuais sobre as coisas e os eventos, perspectivas que, embora não sejam totalmente coincidentes, também não são totalmente excludentes.

A multiplicidade perspectiva atestada pela diversidade de sujeitos perceptivos não implica a instauração de múltiplos mundos privados inacessíveis. A justificativa pela qual Merleau-Ponty rejeita tal instauração reproduz no nível intersubjetivo a comunidade ontológica defendida ao se estudar a relação de um sujeito com o mundo. Quanto à essa relação, o filósofo sustentou que o sujeito perceptivo se compõe de certas propriedades mundanas (visibilidade e tangibilidade, por exemplo), e que as capacidades perceptivas (vidência, tato, e. g.) são somente o inverso de tais propriedades. A atividade senciente se mostra, assim, invariavelmente ligada a uma passividade sensível pela qual o corpo compartilha de atributos mundanos. Daí que a experiência sensível não seja um mero espetáculo privado, mas uma abertura para o mundo tal como ele é: as estruturas perceptivas responsáveis pela experiência não são estranhas aos atributos (sensíveis) do mundo, mas se baseiam neles para funcionar, e não há, assim, nenhum impedimento de princípio para que tais atributos sejam explicitados por meio delas. Ao apresentar o mundo como sensível, a percepção não projeta uma camada de aparências psicológicas sobre um ser em si mesmo incognoscível, mas revela atributos reais que são como aqueles que constituem o

\footnotetext{
${ }^{36} \mathrm{Na}$ verdade, segundo A Prosa do Mundo, no diálogo ocorre mais do que essa simples alternância de papéis: "eu não sou somente ativo quando eu falo, mas eu precedo minha fala no auditor; eu não sou passivo quando eu escuto, mas eu falo segundo... o que o outro diz. Falar não é somente uma iniciativa minha, escutar não é sofrer a iniciativa de outro" (PM, 200). "Na fala se realiza o impossível acordo de duas totalidades rivais (...) porque ela (...) nos transforma no outro, e ele em nós, porque ela abole os limites do meu e do não-meu e faz cessar a alternativa do que tem sentido para mim e do que é não-senso para mim, de mim como sujeito e do outro como objeto" (PM, 202).
} 
próprio corpo percipiente (tangibilidade, visibilidade, etc.). É preciso que haja visibilidade para que a visão ocorra, ou tangibilidade para que o tato atue, e esses poderes subjetivos (visão, tato) se abrem justamente para sua contrapartida passiva que os possibilita (desvelam o mundo como visível, tangível) ${ }^{37}$. De maneira análoga, no caso da intersubjetividade, as experiências de cada sujeito não são senão diferentes aplicações do poder senciente sobre uma base sensível comum, partilhada por todos os corpos percipientes (e pelo mundo). Uma vez que os poderes sencientes surgem da reversibilidade de certas propriedades passivas universalmente partilhadas, eles não constituem reinos privados, mas somente diferentes perspectivas perceptivas transponíveis. Assim, ao menos no nível carnal há comunidade entre os diversos sujeitos.

Essa comunidade sensível entre o mundo e os corpos, responsável tanto por justificar os conteúdos percebidos quanto a possibilidade de relações intersubjetivas, é exprimida por Merleau-Ponty pela noção de carne. O vocábulo "carne" normalmente descreve certos tecidos musculares dos animais e, num sentido mais metafórico e religioso, indica tudo aquilo que é sensível na existência humana por oposição ao espírito. Merleau-Ponty utiliza o vocábulo de modo a amplificar esse caráter sensível tão marcante na existência dos organismos, e aplica-o ao próprio ser. Daí que o filósofo afirme haver uma carne do mundo (Cf. VI, 297, maio 1960): não se trata, sem dúvida, de antropomorfismo, de projetar sobre o ser propriedades exclusivas da subjetividade humana, mas sim de tentar exprimir o caráter sensível partilhado tanto pelo mundo quanto pelo corpo percipiente ${ }^{38}$. Com a noção de carne, Merleau-Ponty busca captar a idéia de uma sensibilidade geral que se manifesta em diferentes situações ou entes sem perder sua unidade ${ }^{39}$.

\footnotetext{
${ }^{37}$ É claro que algumas experiências visuais ou tácteis podem se revelar ilusórias. No entanto, como já expusemos no início do capítulo, os enganos ocasionais são descobertos justamente quando confrontados com experiências tomadas como verdadeiras, as quais, por sua vez, se servem da visibilidade e tangibilidade gerais do mundo como componentes de todas as experiências possíveis.

${ }^{38}$ É dessa maneira que Merleau-Ponty conceitualiza a idéia de um ser que se prepara de seu interior para ser percebido, tal como expôs em seus cursos sobre a natureza (Cf. cap. III).

${ }^{39}$ Vale notar que "a carne do mundo não é se sentir tal como minha carne - ela é sensível e não senciente" (VI, 298, maio 1960). Haar formula um incômodo problema quanto a esse ponto: a carne oferece as condições passivas da experiência (a visibilidade, a tangibilidade). Mas a atividade senciente não pode ser remetida a tal camada sensível do mundo, de modo que nem todos os atributos do corpo decorrem dessa camada, a qual deixa então de ser a fonte única da experiência (Cf. Haar, M. Op. cit., p.28-31). Seria necessário a Merleau-Ponty esclarecer o que deve se acrescentar à carne sensível para que surja a senciência, ou seja, explorar o problema para o qual "reversibilidade" é somente um título e não uma resposta. O filósofo aceita como um fato que o sensível se reverta em seu contrário nos corpos vivos, mas não explora detalhadamente como isso é possível, nem, no geral, a relação entre vida e senciência (cf. nota 19 da conclusão para um outro aspecto do mesmo problema).
} 
A carne atua como um elemento, no sentido em que os gregos definiam o fogo ou o ar, quer dizer, ela é um tipo de ser genérico, que compõe os entes mais diversos, sem se esgotar em nenhum deles. Tomada como elemento, a carne não é identificável a) nem a uma representação subjetiva, b) nem à matéria. Os argumentos de Merleau-Ponty para essa tese são os seguintes (Cf. VI, 181-2):

a) O sujeito não se enreda em suas representações, mas as constrói segundo seu poder intelectual. Porém, em relação à carne, o sujeito está nela inserido, faz parte de uma membrana sensível que escapa ao seu pleno controle. Daí que a carne não seja apenas um ente mental. b) Merleau-Ponty entende matéria no sentido de corpúsculos que se adicionam para formar os objetos. Esses corpúsculos são indivíduos espaçotemporais. Nesse sentido, a carne não é matéria, pois ela é um estilo de ser geral, que se encontra em diferentes momentos e lugares, e não um conjunto de indivíduos ${ }^{40}$.

A noção de carne implica o abandono da cisão total entre sujeito e objeto, já que se trata de um estilo de ser partilhado por ambos. Assim, é verdade que a fé perceptiva parecia unir uma tese "objetiva" e uma "subjetiva", como mencionamos antes. Mas isso só é possível porque antes de assumirem posições antagônicas, sujeito e objeto compartem um mesmo campo sensível. Daí que Merleau-Ponty alegue que a carne designa algo que nunca havia sido tratado pela filosofia tradicional (Cf. VI, 181). Não se trata de exprimir por meio dessa noção uma substância ou mesmo uma região ontológica particular, mas sim um certo nível de ser, um estrato que envolve diferentes entes enumerados pelas ontologias clássicas, e que propicia, desse modo, um novo entendimento das relações entre o ser humano e o mundo. Daí também que o filósofo não tenha desenvolvido sua ontologia como uma enumeração dos entes que existem, conforme apontamos na introdução. Essa enumeração poderia ignorar os níveis ou dimensões pelas quais os entes existem (das quais a carne é um exemplo), dimensões que elas mesmas não são entes.

Deve-se notar que a descrição da carne não encerra a tarefa da ontologia, como se o ser se limitasse a tal camada sensível ${ }^{41}$. A noção de carne fornece os fundamentos ontológicos para compreender como ocorre a abertura perceptiva ao mundo; porém não

\footnotetext{
${ }^{40}$ Merleau-Ponty não expõe: 1) se ele aceita ou rejeita a noção de matéria; 2) se há alguma relação entre a carne e a matéria, se, por exemplo, a primeira poderia ser alguma propriedade emergente da segunda. Dado o inacabamento da sua ontologia, não é possível oferecer um esclarecimento seguro para esses pontos.

${ }^{41}$ Tal como parece julgar G. B. Madison, para quem, "a 'carne' não é senão o Ser", "o ser bruto é a carne" (Madison, G. B. The Phenomenology of Merleau-Ponty. A search for the limits of consciousness. Ed. supra, p.168).
} 
devemos esquecer que concomitantemente a essa abertura, a fé perceptiva também atestava um encobrimento do ser. A ontologia não pode, assim, se satisfazer em apresentar o ser que se manifesta, mas deve refletir acerca desse ser que se oculta, tal como veremos a seguir ${ }^{42}$.

\section{O problema da amplitude do ser}

O enigma da fé perceptiva (apresentação do próprio mundo pelas estruturas subjetivas) é elucidado pela análise da carne, exposta por Merleau-Ponty no quarto capítulo de $O$ Visível e o Invisível. Como vimos, a homogeneidade carnal entre corpo e mundo garante que os conteúdos percebidos não são representações dubitáveis, mas manifestação do estrato sensível comum a $\operatorname{ambos}^{43}$. Pode-se aqui objetar que a caracterização ontológica proposta por Merleau-Ponty se limita a enraizar no mundo propriedades que são reconhecíveis subjetivamente (visibilidade, tangibilidade, etc.), de modo que ainda se continua a tomar os dados da consciência perceptiva como modelo para a definição do ser, exatamente como ocorria na Fenomenologia da Percepção. Dessa maneira, o ser ainda seria concebível como ser perceptível, e, por conseguinte, as críticas sofridas por Merleau-Ponty nos anos quarenta ainda seriam válidas.

A objeção em pauta defende que as teses ontológicas de $O$ Visível e o Invisível se limitam a confirmar a correlação entre o corpo senciente e o mundo sensível, insígnia da Fenomenologia da Percepção. A fim de rejeitar essa conclusão, lembremos, em primeiro lugar, que Merleau-Ponty acentua com veemência que sua caracterização do ser carnal não é antropológica, não é uma narrativa das projeções humanas sobre o mundo (Cf. VI, 177). Sua tese é que o corpo não é só um centro de atividade pelo qual toda paisagem percebida se manifesta como tal, mas que ele participa passivamente do próprio mundo enquanto corpo tangível, visível, em suma, enquanto ente sensível. Importa aqui notar que o caráter sensível do corpo não é uma propriedade meramente subjetiva, mas uma característica partilhada por ele e pelas coisas. Assim, a gênese dessa comunidade não se encontra mais na função de projeção do corpo, a qual

\footnotetext{
${ }^{42}$ Saint-Aubert, que estudou minuciosamente os inéditos de Merleau-Ponty, afirma que não há nenhuma menção em todos os escritos do filósofo francês a uma "ontologia da carne" (Cf. Saint-Aubert, E. Vers une Ontologie Indirecte. Ed. supra, p.148). Quer dizer que a ontologia pretendida por Merleau-Ponty não pode ser adequadamente qualificada como estudo da camada sensível mundana descrita pela carne. Por sua vez, esse filósofo menciona muitas vezes o projeto de uma ontologia do ser bruto ou selvagem, quer dizer, do ser que não foi ainda filtrado pelas capacidades subjetivas, sejam elas intelectuais ou mesmo perceptivas. Parece, assim, que o ser estudado por Merleau-Ponty não se limita ao ser perceptível.

${ }^{43}$ A experiência sensível exibe "a pertença do corpo ao Ser e a pertinência corporal de todo ser que me é de uma vez por todas atestado pelo visível" (VI, 156).
} 
atribuiria ao mundo o caráter sensível ${ }^{44}$, e sim nas propriedades sensíveis do próprio ser. Para $O$ Visível e o Invisível, é porque o ser é sensível que o corpo pode então se voltar para ele. Essa tese inverte aquela da Fenomenologia da Percepção, segundo a qual porque o corpo se volta para o ser e só encontra caracteres sensíveis, então este último deve ser definido como ser sensível ou percebido. Em $O$ Visível e o Invisível, o filósofo admite explicitamente que as coisas, mesmo se elas gravitam em torno dos poderes corporais, "não pressupõem o homem" (VI, 269, nov. 1959), quer dizer, as coisas não existem como entes sensíveis por causa dos atos perceptivos; pelo contrário é porque elas são entes sensíveis que os atos perceptivos podem se exercer corretamente e apresentar o mundo ${ }^{45}$.

Embora as condições da atividade perceptiva tenham sido remetidas ao ser (o qual seria nele mesmo sensível) e não mais derivem das capacidades corporais, a objeção em pauta ainda poderia ser sustentada. Afinal, pode-se pensar que as análises ontológicas de $O$ Visível e o Invisível apenas complementam as descrições sumárias do ser exterior com o qual as capacidades perceptivas deveriam se sincronizar, conforme apresentado pela Fenomenologia da Percepção (Cf. PhP, 247). Vimos, no primeiro capítulo, que Merleau-Ponty não negava, nos anos quarenta, a existência do ser do mundo, mas que o identificava àquilo que poderia se manifestar para as capacidades perceptivas (Cf. $\mathrm{PhP}, 455)$. Parece que em O Visível e o Invisível, ao caracterizar o mundo como carne sensível, Merleau-Ponty confirmaria integralmente sua posição anterior. Afinal, o ser continuaria ainda a se definir somente por propriedades reconhecíveis diretamente pelas capacidades perceptivas (visibilidade, tangibilidade, etc.).

Contra essa interpretação, lembremos que o enigma da fé perceptiva surge porque as estruturas subjetivas não somente se abrem para o ser, mas também o encobrem. O tema da carne (comunidade sensível entre corpo e mundo) esclarece o processo de abertura ao mundo, mas não anula o potencial de encobrimento do ser, em vigor já na própria atividade perceptiva. Notemos que a fé perceptiva engloba tudo aquilo que se doa ao sujeito de maneira originária e original, sem a intermediação de

\footnotetext{
${ }^{44} \mathrm{Na}$ Fenomenologia da Percepção, Merleau-Ponty considerava que o corpo projetava sobre os estímulos um campo fenomenal ordenado (Cf. PhP, 130), de modo que a organização sensível manifestada pelo mundo correspondia às estruturas da existência humana (Cf. $\mathrm{PhP}, 491-2)$.

${ }^{45} \mathrm{Na}$ Fenomenologia da Percepção, não era possível conceber entes ou eventos sensíveis sem pressupor o testemunho tácito da consciência perceptiva humana: "a coisa não pode jamais ser separada de alguém que a perceba, ela não pode jamais ser efetivamente em si, porque suas articulações são aquelas mesmas de nossa existência e porque ela se põe na extremidade de um olhar ou ao termo de uma investigação sensorial que a investe de humanidade" (PhP, 370).
} 
processos reflexivos (Cf. VI, 207-208); ela não se limita, assim, a registrar os dados sensoriais positivamente apreendidos. Daí que no anexo de O Visível e o Invisível, Merleau-Ponty, ao assumir novamente que a meta da interrogação filosófica é descrever o ser com o qual se tem contato originário, afirme que tal meta não implica reduzir o ser àquilo que pode figurar em uma vivência perceptiva. A seguinte passagem sobre o tema é esclarecedora: “não está nem mesmo excluído que encontrássemos [na experiência] um movimento em direção aquilo que em nenhum caso poderia estar presente a nós no original e cuja ausência irremediável incluir-se-ia, assim, no número de nossas experiências originárias" (VI, 209). Merleau-Ponty admite aqui a possibilidade de que não apenas aquilo que se apresenta de maneira positiva seja doado de maneira originária, mas também aquilo que se ausenta. Quer dizer que pode haver ser para além do que se doa positivamente como conteúdo de uma experiência perceptiva. Essa era exatamente a possibilidade explicitada pela ocultação do ser inerente à fé perceptiva: reconhecimento de camadas ontológicas que se ausentam da apreensão direta propiciada pelas capacidades perceptivas, as quais se voltam apenas para a carne sensível do ser. Com a noção de reversibilidade, Merleau-Ponty sustenta que a experiência de fato é uma abertura para o ser e que, no interior dela, pode-se distinguir entre fenômenos verídicos e ilusões. Mas nada disso implica, porém, que as características apreendidas perceptivelmente circunscrevem a totalidade daquilo que é. O ser não só se mostra para a fé perceptiva, mas também se encobre perante ela. Esse encobrimento, que exige um método indireto para ser investigado (já que seu conteúdo justamente não se doa diretamente às capacidades perceptivas) será tematizado ao Merleau-Ponty estudar, por exemplo, as dimensões invisíveis pelas quais os fatos se organizam, e, no geral, por todos os aspectos negativos do ser, quer dizer, aqueles que não se reduzem aos dados apreendidos de maneira positiva pela percepção. Vimos que ao analisar a experiência da doação originária na Fenomenologia da Percepção, Merleau-Ponty recebeu diversas críticas por haver assumido um certo idealismo subjetivista. Em O Visível e o Invisível, ao retomar o projeto de estudar a doação originária, Merleau-Ponty já antecipa a objeção de idealismo $^{46}$. Veremos, na conclusão de nosso trabalho, que em sua resposta a tal objeção Merleau-Ponty reconhece uma maior amplitude do ser em relação às propriedades perceptivelmente apreensíveis, de maneira a romper com o pendor idealista da ontologia contida na Fenomenologia da Percepção.

\footnotetext{
46 "O propósito de perguntar à própria experiência seu segredo não é já uma decisão [parti pris]
} idealista?" (VI, 209). 


\section{Conclusão - Uma concepção de ser renovada}

\section{Sinopse}

Neste capítulo final, retomamos inicialmente os problemas filosóficos derivados da tese de que o ser se limita ao que é apreensível pelas capacidades perceptivas, defendida na Fenomenologia da Percepção. Em seguida, analisamos, em duas partes, como, em sua ontologia ulterior, Merleau-Ponty resolve os inconvenientes de sua posição inicial. $\mathrm{Na}$ primeira delas, expomos como a noção de carne fornece uma justificativa, obtida por uma metodologia indireta, ao papel de cânone ontológico atribuído à percepção. $\mathrm{Na}$ segunda, mostramos como Merleau-Ponty complementa a noção de carne com a idéia de uma negatividade ontológica, a qual evita a redução do ser àquilo que é perceptível.

\section{A) Retomada geral}

\section{O problema do idealismo}

No primeiro capítulo, vimos que longe de se limitar a uma descrição da experiência subjetiva, a Fenomenologia da Percepção envolve reflexões ontológicas, pois descreve os fenômenos como um modo de ser originário em relação à objetividade e à subjetividade. Com efeito, uma das principais metas desse livro era mostrar como o ser, antes de limitar-se a um conjunto de objetos absolutamente independentes ou de representações subjetivas, manifesta-se como ser percebido, quer dizer, como um campo de configurações fenomenais pré-objetivas, que estariam correlacionadas aos poderes intencionais pré-subjetivos do corpo próprio. No entanto, desde logo depois de sua publicação, a Fenomenologia da Percepção recebeu várias críticas, dentre as quais utilizamos aquelas de Alquié e Desanti como ponto de partida para explicitar como Merleau-Ponty involuntariamente acaba por se filiar, nesse livro, ao idealismo subjetivista, concepção segundo a qual o ser se limita ao que a percepção humana pode apreender ${ }^{1}$.

A incômoda proximidade com o idealismo, explicitamente rejeitada por Merleau-Ponty, torna-se evidente (segundo nossa interpretação) ao se analisar suas teses acerca do passado do mundo antes da existência humana. Segundo Merleau-Ponty, os eventos que antecederam o surgimento da vida humana (tais como a formação da Terra por meio de uma nebulosa) não excederiam em nada os poderes perceptivos humanos, uma vez que só poderiam ser concebidos por meio de tais poderes (quer dizer,

\footnotetext{
${ }^{1}$ Nossos argumentos para tal conclusão estão expostos na segunda seção do primeiro capítulo.
} 
concebidos como eventos que são visíveis, audíveis, etc.). Assim, a existência de tais eventos só poderia nos aparecer como aquela de entes culturais construídos conforme as habilidades perceptivas humanas. Pareceu-nos, assim, que Merleau-Ponty, na Fenomenologia da Percepção, não dispõe de instrumentos teóricos que lhe permitam admitir a existência autônoma dos eventos constituintes do passado do mundo. Nesse livro, o filósofo silencia acerca da existência dos processos anteriores à vida humana tomados por si mesmos, ou seja, acerca de tais processos considerados independentemente da concepção que os seres humanos deles formulam (e, da mesma forma, Merleau-Ponty também não problematiza adequadamente o tema da existência autônoma de qualquer dimensão ou componente do mundo de direito invisível). Essa lacuna na concepção ontológica contida em tal obra legitima as críticas de idealismo recebidas.

\section{O itinerário de Merleau-Ponty}

Conforme já mencionamos no primeiro capítulo, Merleau-Ponty jamais pretendeu desenvolver uma doutrina idealista. Para ele, a interpretação de seu projeto filosófico como idealismo é um grave mal-entendido. Entretanto, o filósofo chega mesmo a admitir que, tal como formulado na Fenomenologia da Percepção, seu projeto filosófico poderia ser de fato interpretado erroneamente, e que era necessário esclarecer sua intenção filosófica (Cf. VI, 228, 234, fev. 1959).

Acompanhamos, a partir do segundo capítulo, o percurso de Merleau-Ponty para o amadurecimento de sua reflexão ontológica, de modo a suprir as lacunas teóricas da Fenomenologia da Percepção. Interessou-nos particularmente acentuar as diversas linhas de trabalho pelas quais Merleau-Ponty aperfeiçoa a posição filosófica exposta na Fenomenologia da Percepção (Cf. cap. III, IV, V). Além disso, tentamos esclarecer em que medida, por meio da ampliação do escopo de sua investigação (de modo a enfatizar notadamente a linguagem), o filósofo elabora uma refinada concepção da expressão filosófica (Cf. cap. II), a qual é aplicada na formulação dos principais tópicos de sua obra final, $O$ Visível e o Invisível (Cf. cap. VI). Cumpre-nos agora expor de modo mais sistemático as principais teses da ontologia final de Merleau-Ponty, e esclarecer em que medida elas resolvem os problemas da sua ontologia fenomenológica inicial. 
Servimo-nos, como texto básico para tal exposição, das notas de trabalho dos últimos anos de vida do filósofo ${ }^{2}$. Essa opção se justifica porque tais notas, mesmo não tendo sido escritas para publicação, registram a vivacidade das reflexões finais do autor. $\mathrm{O}$ fato de que tais reflexões não chegaram a se completar devido à morte prematura do filósofo ainda mais nos obriga a apelar a tais notas, já que por meio delas dispomos de um registro pelo qual a imagem geral da sua última ontologia pode ao menos parcialmente ser restituída. Deve-se observar também que as notas de trabalho são contemporâneas de outros textos ou cursos escritos por Merleau-Ponty ${ }^{3}$. A sua escolha como texto de base para este último capítulo se deve, assim, à possibilidade de confirmar (mas também de esclarecer e, nesse sentido, ampliar) as principais teses ontológicas expostas nesses outros textos, os quais, ao menos em sua maioria, foram estudados por nós nos capítulos anteriores deste trabalho.

\section{B) A carne}

\section{O método indireto da ontologia}

Vimos, no primeiro capítulo, que Merleau-Ponty já nos anos quarenta buscava descrever um nível ontológico pré-objetivo (que não se confunde com as propriedades objetivas estudadas pelas ciências) e pré-subjetivo (que não se confunde com as idéias e representações da consciência cognitiva) (Cf. PhP, 73-77). Tal nível era então descrito como campo fenomenal, quer dizer, como campo de "aparências" que ainda não são puros objetos e cujo aparecer está relacionado com as estruturas perceptivo-motoras da vida corporal anônima. Defendemos, ainda no primeiro capítulo, que mesmo não tendo apresentado esse campo originário como uma criação subjetiva, Merleau-Ponty ainda se mantém preso, na Fenomenologia da Percepção, a uma postura idealista, já que nessa obra o ser manifestado por tal campo se define em termos daquilo que é perceptível pela subjetividade humana. Essa conseqüência é confirmada por Merleau-Ponty no artigo "O metafísico no homem", de 1947, em que reconhece como fato fundante de sua investigação ontológica (designada então como metafísica) a asserção de que só há ser para mim (Cf. SnS, 114). Assim, Merleau-Ponty concedia, nessa época, uma

\footnotetext{
${ }^{2}$ Além das notas publicadas em $O$ Visivel e o Invisível, utilizaremos algumas notas inéditas transcritas por Renaud Barbaras e gentilmente cedidas para pesquisa. A fim de que os leitores apreciem de maneira independente esses textos, reproduzimos, no apêndice, em sua integridade (ou ao menos os excertos principais, como no caso do item a) as notas inéditas citadas neste trabalho.

${ }^{3}$ As notas a serem citadas aqui foram compostas entre 1958 e 1961. Nesses anos, Merleau-Ponty ministrou cursos sobre a natureza, sobre Husserl e sobre a possibilidade da filosofia. Além disso, publicou O Olho e o Espírito e escreveu artigos importantes tais como "O filósofo e sua sombra".
} 
proeminência tal à subjetividade encarnada de maneira a atribuir a ela o papel de única medida pela qual se poderia decidir sobre o que existe e o que não existe.

Em algumas notas inéditas do final dos anos cinqüenta, um caminho alternativo para o desenvolvimento da ontologia é indicado: "nossa corporeidade: não colocá-la no centro como eu fiz na Fenomenologia da Percepção", nota, Merleau-Ponty analisa possíveis caminhos para progredir em suas reflexões ontológicas. Um deles é o seguinte: "partir dos resultados da Fenomenologia da Percepção e mostrar que é necessário transformá-los em ontologia: 1/ passar da afirmação do 'percebido' àquela do Ser bruto, 2/ passar da idéia do corpo como sujeito àquela do ser indiviso"5. Nessas duas notas, Merleau-Ponty exprime sua intenção de rejeitar o papel central atribuído à subjetividade encarnada para então poder avançar em seu projeto de descrever um campo de ser anterior à cisão entre sujeito e objeto. Um contraste com a Fenomenologia da Percepção tornará clara a intenção filosófica em pauta aqui. Segundo o livro de 1945, “o corpo próprio está no mundo como o coração no organismo: ele mantém continuamente em vida o espetáculo visível, ele o anima e o nutre interiormente, e forma com ele um sistema" ( $\mathrm{PhP}, 235)$. Quer dizer que os aspectos sensíveis do mundo só se ordenam em função da atividade corporal, a qual condiciona a própria existência dos espetáculos visíveis. Já em $O$ Visível e o Invisível, Merleau-Ponty assume a tarefa de "descrever o visível como algo que se realiza por meio do homem, mas que não é absolutamente antropológico" (VI, 322, março 1961). Aqui, os espetáculos visíveis (e, no geral, os aspectos sensíveis do mundo) são considerados anteriores e independentes das capacidades subjetivas. Embora se realizem por meio de tais capacidades (ou seja, se manifestem ao sujeito como sensíveis), tais aspectos são tratados como componentes inerentes do ser do mundo e não pressupõem a subjetividade para existir.

Notemos, tal como Merleau-Ponty anuncia em uma das notas inéditas citada acima, que a alternativa vislumbrada ante a rejeição da centralidade do corpo é o ser bruto ou indiviso. Quer dizer que o estudo desse ser não está comprometido com a perspectiva teórica que se limita a investigar aquilo que se manifesta para as capacidades corporais. Segundo Merleau-Ponty, essa perspectiva é aquela da fenomenologia. Essa doutrina, defende o filósofo, pressupõe uma ontologia segundo a qual tudo o que existe deve se apresentar à consciência como elo numa cadeia

\footnotetext{
${ }_{5}^{4}$ Nota n.50, sem data, agrupada ao esboço de Être et Monde. Ver item a do apêndice.

${ }^{5}$ Texto n.13 (Mercredi, 7/10/58 [?]). Ver item b do apêndice.
} 
interminável de vivências ordenadas segundo uma temporalidade imanente (Cf. VI, 293, abril 1960). Embora ao mencionar tal ontologia Merleau-Ponty se dirigisse explicitamente aos textos de Husserl, é possível nela reconhecer algumas teses da Fenomenologia da Percepção, obra segundo a qual a consciência perceptiva anônima porta em si as estruturas pelas quais todo ser possível pode se manifestar ( $\mathrm{Cf}$. $\mathrm{PhP}, 377$, 411, 490). Assim, romper com o papel central da subjetividade encarnada, tal como as notas inéditas citadas no parágrafo anterior sugerem, implicará distanciar-se da análise fenomenológica. Trata-se, por conseguinte, de formular uma investigação ontológica que não se limite a narrar os conteúdos da correlação entre experiência corporal e componentes do mundo, mas que explicite o campo de ser bruto no qual ambos se originam $^{6}$.

Deixemos claro de que maneira a descrição fenomenológica de Merleau-Ponty está comprometida com aquela ontologia que, como vimos no parágrafo anterior, o filósofo francês atribui a Husserl. Nós havíamos notado, em nosso primeiro capítulo, que Merleau-Ponty admite na Fenomenologia da Percepção que a atividade perceptiva é resposta a um ser que a precede e que a motiva (Cf. PhP, 248). Naquele livro, porém, Merleau-Ponty praticamente se limita a investigar a resposta perceptiva ao ser (ou seja, o mundo que é percebido), e julga, por meio dessa análise, esclarecer o problema do ser que antecede a vida perceptiva. É como se Merleau-Ponty identificasse o ser que está na origem da percepção com os resultados da atividade perceptiva. Ora, no curso "As ciências do homem e a fenomenologia" (1952), uma identificação bastante semelhante, entre o ambiente geográfico (o mundo, considerado em si próprio) e o ambiente fenomenal (o mundo ou o ser percebido) é criticada. Essa identificação supõe que existe um transporte perfeito das propriedades das coisas para a percepção, ou seja, que não há diferença entre as causas e o resultado da percepção. No entanto, tal suposição não pode ser mantida. Por vezes aquilo que é idêntico no ambiente geográfico aparece como diferente no campo fenomenal ${ }^{7}$. Da mesma forma, por vezes, aquilo que é diferente no ambiente geográfico aparece como idêntico no campo fenomenal ${ }^{8}$. Com efeito, já na Fenomenologia da Percepção, Merleau-Ponty reconhecia que, em certos casos, o

\footnotetext{
${ }^{6}$ Tal como expusemos em nosso quinto capítulo, a posição final de Merleau-Ponty em relação à fenomenologia não é de desprezo, mas de reelaboração de alguns de seus temas e resultados em um quadro ontológico mais amplo.

${ }^{7}$ Conforme a ilusão de Jastrow, em que "segmentos de círculos iguais e paralelos são percebidos como diferentes" (PPE, 431).

8 "Dois pontos, um branco sobre fundo negro, o outro negro sobre fundo branco, que têm a mesma função, são identificados na percepção" (PPE, 431)
} 
fenômeno percebido não segue pontualmente os estímulos percebidos e se organiza segundo uma lógica própria (Cf. PhP, 14). Por conseguinte, conforme essas asserções do próprio Merleau-Ponty, o campo fenomenal não reproduz fielmente o ser motivador da percepção, mas impõe-lhe parâmetros próprios de organização dos dados assimilados. Essa tese implica que a mera descrição direta dos dados percebidos não basta para explicitar todas as características do ser do mundo, de modo que uma ontologia não pode se fiar apenas em tal descrição. Vimos, ao analisar a Fenomenologia da Percepção, que, descrito por meio dos resultados da atividade perceptiva, o ser do mundo se limitava àquilo que podia figurar no fluxo de vivências subjetivas, e era, desse modo, identificado ao mundo fenomenal percebido. Com tal postura, Merleau-Ponty parecia então filiar-se ao idealismo subjetivista. Porém, nos anos cinqüenta, o filósofo desenvolve uma nova abordagem ontológica e busca analisar de maneira autônoma esse ser de que a percepção se origina, sem sobrepor a ele (ao menos não de imediato), os resultados da vida perceptiva.

Aqui cabe perguntar como deve proceder uma ontologia que rejeita a descrição fenomenológica das vivências subjetivas como principal procedimento metodológico. Numa nota de fevereiro de 1959, publicada em O Visível e o Invisível, Merleau-Ponty enaltece o método científico que considera como desconhecidos os temas a serem estudados. Por exemplo, ao examinar as estruturas da linguagem, o lingüista desconsidera o fato de que tais estruturas são vividas pelos próprios cientistas. Dessa maneira, é possível descobrir condicionantes inaparentes de tais estruturas, os quais seriam indevidamente ignorados caso se acentuasse em demasia a vivência subjetiva de tais estruturas (Cf. VI, 232-3, fev. 1959). Segundo Merleau-Ponty, esse distanciamento metodológico do tema a ser estudado é um dos principais componentes de toda reflexão crítica (VI, 233, fev. 1959), e serve de modelo para os esforços filosóficos. Por conseguinte, a análise filosófica não deve se limitar a uma descrição fenomenológica do fluxo subjetivo de vividos ${ }^{9}$. Com efeito, o estudo do ser bruto pretendido por MerleauPonty não será derivado da descrição das experiências vividas, mas será realizado por meio de uma restituição indireta da camada originária que alimenta a vivência subjetiva. Trata-se de aproximar-se do ser por meio dos seres, ou seja, por meio de diversos estudos dos entes do mundo (estudos científicos e artísticos, por exemplo). Esses estudos auxiliam a romper com definições dogmáticas do ser, baseadas apenas na

\footnotetext{
9 “Essa reflexão não é, não pode ser limitação à fenomenologia dos Erlebnisse [vivências]. (...) A filosofia não tem nada a ver com o privilégio dos Erlebnisse, da psicologia da vivência, etc.” (VI, 233, fev. 1959).
} 
descrição direta das vivências, e também indicam diversos tópicos a serem desenvolvidos pela filosofia ${ }^{10}$. A própria escrita filosófica deve reproduzir esse movimento argumentativo indireto. Segundo Merleau-Ponty, quando se tenta caracterizar positivamente o ser (para além da contribuição no geral negativa das ciências), não se deve buscar traduzir uma experiência privilegiada do ser, um contato direto com as estruturas ontológicas do mundo, mas sim tentar fixar um estado de coisas ao qual não se tem acesso claro antes da sua expressão (Cf. cap. II).

Lembremos, como já expusemos no quarto capítulo, que o método indireto já era utilizado por Merleau-Ponty na Fenomenologia da Percepção. No entanto, tal método não contribuía para a definição de ser ali em vigor, a qual derivava da identificação daquilo que é àquilo que se manifesta à consciência perceptiva (Cf. PhP, 455). É nesse sentido que a ontologia daquele texto é fenomenológica: a compreensão geral de ser decorre de uma análise daquilo que se fenomenaliza para a consciência humana. Já nos anos cinqüenta, a concepção de ser não se segue de uma análise daquilo que se apresenta diretamente à consciência subjetiva, mas de uma investigação de diversos índices sugeridos pelas ciências e artes em geral. Aplica-se assim o método indireto para a própria definição do que se compreende por ser.

\section{A sensibilidade intrínseca ao ser}

O rompimento com a familiaridade da vivência subjetiva (marca distintiva do método indireto), e o conseqüente abandono da descrição da experiência perceptiva como caracterização do ser, não implicarão, entretanto, admitir que o ser é essencialmente estranho à subjetividade e que todo contato entre ambos é contingente. Merleau-Ponty pretende que o rompimento inicial com os dados fenomenológicos (de modo a rejeitar a centralidade da vida subjetiva e as conseqüências idealistas daí decorrentes) estabeleça uma familiaridade entre o sujeito e o ser ainda mais fundamental $^{11}$ do que aquela derivada da definição do ser como ser para mim (definição segundo a qual tudo aquilo que existe se conforma aos parâmetros de apreensão subjetiva de dados sensíveis). O estabelecimento dessa nova familiaridade ocorre porque em vez de tomar o escopo de atuação das capacidades perceptivas como a

\footnotetext{
${ }^{10}$ Conforme vimos no quarto capítulo, não há teses ontológicas prontas nas ciências ou artes, mas sim índices de uma concepção ontológica que cabe à filosofia desenvolver.

11 "Essa abstenção de toda Einfühlung [empatia] com a linguagem, com os animais, etc. reconduz a uma Einfühlung superior, é destinada a torná-la possível” (VI, 233, fev. 1959).
} 
extensão daquilo que existe, Merleau-Ponty passa a buscar a gênese da própria sensibilidade nos padrões de organização inerentes ao mundo.

Essa mudança de perspectiva metodológica implica, na verdade, a inversão do procedimento fenomenológico (que partia da experiência para então qualificar o ser como aquilo que é percebido). Tal inversão é tornada clara em duas notas de trabalho. Num texto inédito de 1958, Merleau-Ponty considera algumas maneiras de retomar os resultados da Fenomenologia da Percepção e avançar para além deles. Uma das alternativas seria reconhecer que o ser "é, não o percebido, mas isto em vista do que há percepção" ${ }^{\prime 2}$. Uma nota de novembro de 1959, publicada em O Visível e o Invisível, exprime a mesma idéia. Segundo esse texto, “o próprio do percebido: estar já aí, não ser pelo ato de percepção, ser a razão desse ato" (VI, 268). Essas duas notas esclarecem que não se deve caracterizar o ser como sensível apenas porque ele é efetivamente percebido assim pelo corpo, como se a subjetividade humana tivesse o poder de atribuir essa propriedade às coisas e ao mundo. Pelo contrário, é porque o ser é em si mesmo visibilidade, sensibilidade latente, que a percepção pode então se exercer e confirmar o caráter sensível do mundo. Desse modo, porque se organiza autonomamente como sensível, o ser, longe de se opor à subjetividade (como a clássica cisão entre sujeito e objeto levava a supor), é aquilo que prepara, do seu interior, a sua apreensão subjetiva ${ }^{13}$. Quer dizer que o ser é solidário com uma visão sobre o ser, no sentido de que há uma sensibilidade inerente ao mundo, a qual se doa para o foco subjetivo, que então a recolhe ${ }^{14}$. Merleau-Ponty assevera em uma nota inédita que essa concepção do ser como sensibilidade iminente "incorpora o homem na definição do mundo, faz aparecer o homem como ingrediente do mundo, pedaço do mundo que se dobra sobre si próprio"15. A percepção humana é, segundo essa perspectiva, parte de um processo de manifestação sensível inerente ao próprio ser.

Essa última sentença permite comprovar que a ontologia indireta de MerleauPonty cumpre a promessa de revelar uma familiaridade originária entre a experiência humana e as estruturas ontológicas do mundo (Cf. VI, 233, fev. 1959). Lembremos que a ontologia derivada das descrições da Fenomenologia da Percepção limitava-se a caracterizar o ser como aquilo que se apresentava às capacidades subjetivas de

\footnotetext{
${ }_{12}^{12}$ Nota $12 b$, ver item c do apêndice.

${ }^{13}$ O ser "não se opõe ao para si”, mas, antes, "só tem coesão para um si” (VI, 250, julho 1959).

${ }^{14}$ Aqui vale retomar os exemplos de mimetismo (cf. cap. III), fenômeno que evidencia que um dos fatores de organização das formas animais é o fato de que elas serão vistas por outros animais.

${ }^{15}$ Nota 12 de um grupo de 22. Ver item d do apêndice.
} 
apreensão perceptiva (Cf. PhP, 455). O ser era então reduzido ao ser perceptível apenas porque esse era o limite que as estruturas do corpo podem apreender. Por sua vez, os estudos tardios da ontologia indireta mostram que não é somente por essa razão que se deve conceber o ser como ser perceptível, mas sim em razão da própria arquitetônica interna ao mundo. Nos textos tardios de Merleau-Ponty, a tese de que o ser é por sua própria organização sensível não decorre de uma análise direta dos conteúdos positivos da experiência perceptiva, mas é justamente a tese que legitima a pretensão de que tais conteúdos revelem o ser tal como ele é.

Notemos que, por meio do método indireto, Merleau-Ponty admite claramente a independência do ser em relação à existência humana, assunção que, conforme nosso primeiro capítulo, não estava posta de uma maneira clara na Fenomenologia da Percepção ${ }^{16}$. Nos anos finais, para se afirmar que há ser não é necessário reconhecer haver uma correlação com as capacidades perceptivas humanas. No entanto, o reconhecimento de tal independência não significa reatar com uma concepção objetivista do em-si, a qual definiria o ser como conjunto de propriedades físicoquímicas inatingíveis pela atividade perceptiva humana ${ }^{17}$. Assim, Merleau-Ponty admite que o mundo existe de maneira autônoma; mas também sustenta que em seu próprio desenvolvimento o mundo se abre para uma perspectiva subjetiva, constitui-se como algo que se doa a aparelhos perceptivos, os quais, como vamos enfatizar a seguir, não são algo estranho ao ser do mundo, mas estruturas que partilham do seu estofo ontológico $^{18}$.

\footnotetext{
${ }^{16}$ Numa nota publicada de novembro de 1959, Merleau-Ponty reconhece que "as coisas não pressupõem o homem" (VI, 269). Numa nota inédita, afirma "a anterioridade do em-si sobre o para-si" (nota 40b, de 1955; ver item e do apêndice).

${ }^{17}$ Na mesma nota inédita de 1955, Merleau-Ponty assevera: "esse em-si, eu me nego a concebê-lo como o faz o realismo dos cientistas, eu digo que em sua própria textura ele reenvia a meu (um) centro de perspectiva, que deve se conceber em termos de espetáculo percebido" (nota 40b, ver item e do apêndice). ${ }^{18} \mathrm{O}$ movimento argumentativo que localiza no próprio ser as bases pelas quais as capacidades humanas podem ser exercidas aproxima Merleau-Ponty da última filosofia de Heidegger, o qual, após a famosa Kehre, passou a priorizar o auto-desvelamento do ser e não mais o Dasein humano como o ente pelo qual se poderia compreender tal desvelamento. Michel Haar defende que Merleau-Ponty parece ter retido da ontologia heideggeriana somente "o esquema regulador da prioridade do Ser sobre o homem" (Haar, M. "Proximité et distance vis-à-vis de Heidegger chez le dernier Merleau-Ponty". Ed. supra, p.14), já que a problemática de um ser sensível que contém o estofo de todas as estruturas ulteriores (Cf. VI, 250, julho 1959) é estranha a Heidegger. Saint-Aubert confirma a tese de Haar ao notar que, nos anos finais, Merleau-Ponty de fato assume alguns termos do léxico heideggeriano, mas apenas como instrumentos para desenvolver uma reflexão própria, sem se preocupar em filiar-se às posições do filósofo alemão (Cf. Saint-Aubert, E. Vers une Ontologie Indirecte. Ed. supra, p.103).
} 


\section{A comunidade carnal entre sujeito e mundo}

A caracterização do ser como inerentemente sensível é uma tese filosófica pela qual Merleau-Ponty pretende superar a cisão entre sujeito e objeto em que a Fenomenologia da Percepção teria ficado presa (Cf. VI, 250, julho 1959). Segundo sua ontologia final, o ser sensível contém as condições da sensibilidade posteriormente exercida pelo sujeito perceptivo. Dessa maneira, ao incluir a sensibilidade na definição do ser, Merleau-Ponty desvela um campo ontológico que antecipa as capacidades subjetivas sem se reduzir a um constructo subjetivo (já que tal campo existe de maneira autônoma e não apenas por ser correlato da experiência subjetiva). Por sua vez, esse campo de ser sensível não se reduz à pura objetividade, noção que excluía as características sensíveis do ser mundano e as concebia como efeito psicológico da relação entre sujeito e ambiente.

Notemos que a atribuição de sensibilidade ao ser permite esclarecer a relação perceptiva estabelecida entre o sujeito e tal ser sensível. De início, a afirmação de que o ser se prepara do seu interior para se manifestar a uma subjetividade, de que o ser se dirige para um foco de visão, pode alimentar a incômoda suspeita de que tal foco não faz parte desse ser que se revela, o que reinstalaria um tipo de dualismo substancial. Contra essa suspeita, Merleau-Ponty elabora a tese da sensibilidade inerente ao ser por meio da noção de carne. Tal como vimos em nosso capítulo anterior, com essa noção, tenta-se captar a sensibilidade geral partilhada pelo corpo humano e pelo mundo, ou seja, a comunidade de fundo entre os pólos subjetivo e objetivo. Não basta, assim, mostrar que o ser é sensível e se abre para uma apreensão subjetiva; trata-se de esclarecer que o sujeito perceptivo se compõe dessa mesma sensibilidade inerente ao mundo. A subjetividade humana não é, segundo tal perspectiva, um puro exercício de poderes intencionais completamente heterogêneos às estruturas do mundo, mas é fruto da concentração de tais estruturas em um ente particular (o corpo percipiente). É verdade que o corpo, pondera Merleau-Ponty, não se reduz a uma coisa sensível em meio a outras coisas, pois é o mensurador geral pelo qual todas as coisas aparecem como percebidas (Cf. VI, 297, maio 1960). No entanto, o filósofo assevera: "é pela carne do mundo que se pode afinal de contas compreender o corpo próprio" (VI, 299, maio 1960), ou seja, é apenas porque há um ser que em si mesmo é sensibilidade iminente (carne do mundo) que a carne corporal pode exercer seu papel ativo. Dessa maneira, com a noção de carne Merleau-Ponty pretende finalmente ter se esquivado da 
cisão entre sujeito e objeto sem favorecer nenhum desses termos extremos, mas por reconhecer o elemento comum de que ambos derivam ${ }^{19}$.

Por meio da noção de comunidade carnal entre corpo e mundo, Merleau-Ponty pretende corrigir ao menos mais um problema localizado por ele mesmo na Fenomenologia da Percepção. Em O Visível e o Invisível, o filósofo admite que seu livro anterior se mantém ao menos em parte filiado à filosofia da consciência (Cf. VI, 237, fev. 1959), ou seja, a uma filosofia que prioriza a subjetividade reflexiva na compreensão quer do contato de si com o mundo quer do contato de si consigo. Na Fenomenologia da Percepção, Merleau-Ponty combate de maneira explícita o primado da consciência reflexiva quanto ao contato humano com o mundo ${ }^{20}$. No entanto, no que se refere ao contato da subjetividade consigo, Merleau-Ponty de fato parece ainda admitir um contato direto consigo. Essa seria a consequiência da assunção da idéia de cogito tácito naquela obra. Com tal idéia, Merleau-Ponty pretendia garantir que a subjetividade integrasse os diversos episódios de sua vida de modo a apreender-se a si própria, do seu interior, como una. Segundo a Fenomenologia da Percepção, essa apreensão não ocorre de maneira transparente, quer dizer, por meio de uma reflexão que ativamente sintetizaria todas as vivências particulares. Haveria uma remissão espontânea de todas as vivências particulares à abertura perceptiva geral pela qual o sujeito se relaciona com seu ambiente. Essa abertura geral conteria em si mesma o projeto de toda manifestação fenomênica possível, quer dizer, um repertório de capacidades por meio das quais toda configuração perceptiva pode ser assimilada pelo

\footnotetext{
${ }^{19}$ Michel Haar não se convence de que tal resultado tenha sido obtido por completo. Como vimos, Merleau-Ponty teria localizado a gênese das capacidades perceptivas no próprio ser, de modo a dar um caráter secundário à atividade subjetiva em relação à sensibilidade inerente ao mundo. Para Haar, "a essência dessa subjetividade descentrada - que não tem mais a iniciativa da síntese perceptiva, e nem da fala ou do pensamento, do mesmo modo que ela não se deu a vida - permanece totalmente não pensada" (Haar, M. Art. cit.., p.22-3). Segundo Haar, a insuficiência de Merleau-Ponty em conceber adequadamente o modo de ser da subjetividade descentrada torna-se explícita, por exemplo, na sua exposição da senciência. Como dissemos, Merleau-Ponty pretende exibir as condições da percepção na sensibilidade inerente ao ser. Mas essa sensibilidade é eminentemente passiva e a percepção, por sua vez, se exerce de modo ativo, como senciência. Merleau-Ponty apenas menciona que a senciência resultaria de uma parte sensível do mundo (o corpo próprio) voltar-se para o resto do mundo (Cf. VI, 299, maio 1960), mas não esclarece o que é esse voltar-se, ou seja, como a atividade surge de um ser passivo. Haar problematiza a posição de Merleau-Ponty ao perguntar: se a carne do mundo é só sensível e não senciente (Cf. VI, 298, maio 1960), se "ela tem menos atributos que meu corpo, como é possível lê-la como uma matriz e um 'meio' universal, um 'elemento'? Como afirmar que 'meu corpo é feito da mesma carne que o mundo', se essa carne é infinitamente mais pobre que a minha?" (Haar, M. Art. cit., p.28). A senciência não teria, assim, sua gênese no ser carnal, o qual é eminentemente passivo. A fim de evitar a estranha consequiência de que a senciência não está incluída no próprio ser de que a subjetividade surge, seria preciso esclarecer melhor a sua origem.

${ }^{20}$ Cf., por exemplo, o capítulo “A espacialidade do corpo próprio”, em que Merleau-Ponty descreve uma intencionalidade própria à atividade corporal, irredutível à intencionalidade da consciência cognitiva.
} 
sujeito (Cf. PhP, 411). Dessa maneira, toda vivência particular se refere a um cogito tácito, pelo qual o sujeito se reconhece em todos os seus engajamentos parciais ${ }^{21}$. Mesmo com a ressalva de que a unificação das vivências não ocorre por uma reflexão ativa, Merleau-Ponty ainda sustenta, na Fenomenologia da Percepção, uma presença a si da consciência por meio de uma ligação interna entre as vivências. É exatamente essa tese que será abandonada em sua ontologia final, como veremos a seguir.

A noção de carne implica tomar a subjetividade como parte de um campo de sensibilidade mundana. $\mathrm{O}$ sujeito não é senão um foco em que tal sensibilidade se concentra e, de maneira ativa, volta-se sobre o próprio mundo. No sujeito ocorre, assim, uma reversibilidade entre sua camada passiva (sensível) e ativa (senciente): o sujeito é um foco de atividade, mas tal foco não é incomensurável com o ser do mundo, pois se sustenta pelo caráter passivo/sensível do corpo. A idéia de reversibilidade auxilia Merleau-Ponty a reformular a concepção de unificação dos vividos por meio de um contato interno de si consigo, tese defendida pela Fenomenologia da Percepção. Conforme os textos finais de Merleau-Ponty, o sujeito só se reconhece como fluxo ativo de vivências por meio da sua base passiva. Assim, por exemplo, o sujeito vidente não se apreende a si mesmo como um foco ativo de visão, mas sim como um ente visível em meio a outros visíveis. Quer dizer que o sujeito não unifica suas vivências por um contato interno consigo que acompanharia todo engajamento particular, mas se apreende ao reconhecer a si próprio como sujeito passivo e inserido no mundo sensível. Esse reconhecimento não atinge a coincidência total de si consigo, uma vez que, segundo Merleau-Ponty, as duas camadas reversíveis do corpo jamais se identificam, quer dizer, o corpo não pode apreender a si mesmo como corpo ativo, mas somente como corpo passivo. Por exemplo, o sujeito vidente se apreende como visível e não como poder explorador, o corpo tocante se reconhece como massa tocada e não como puro poder tocante (Cf. VI, 309, nov. 1960). Assim, a noção final de sujeito esboçada por Merleau-Ponty dispensa a coincidência consigo e é marcada apenas por uma "nãodiferença" (VI, 254, set. 1959) entre suas camadas constituintes ${ }^{22}$.

\footnotetext{
21 "Ultrapassado de todos os lados por meus próprios atos, afogado na generalidade, todavia sou aquele por quem eles são vividos, com minha primeira percepção foi inaugurado um ser insaciável que se apropria de tudo aquilo que pode encontrar, a quem nada pode ser pura e simplesmente dado porque ele recebeu o mundo em partilha e desde então traz em si mesmo o projeto de todo ser possível, porque de uma vez por todas este foi cimentado em seu campo de experiências" (PhP, 411).

${ }^{22}$ Cassou-Noguès extrai bem as conseqüências dessas teses tardias de Merleau-Ponty: "a experiência de si, se ver, falar de si ocorre na carne e não na interioridade do sujeito. O sujeito só se apreende do exterior, reconhecendo-se em um corpo dado no campo do visível, identificando-se com palavras
} 
Vimos que com a noção de carne, Merleau-Ponty esboça a idéia de um campo ontológico anterior à cisão entre sujeito e objeto, e desenvolve uma nova análise da reflexão e da subjetividade. Cumpre notar agora que esses dois resultados reunidos justificam o proeminente papel atribuído por Merleau-Ponty à percepção (desde seus primeiros escritos até seus textos finais) de medida pela qual todo tipo de ser pode ser concebido. Já expusemos que em seus anos finais o filósofo analisa o ser não como correlato da experiência humana, mas como campo sensível do qual tal experiência se origina. Desse modo, não se considera ser somente aquilo que é percebido (tal como ocorria na Fenomenologia da Percepção), mas, pelo contrário, porque o ser é sensível, esclarece-se como pode haver percepção. Quer dizer que a atividade perceptiva é secundária em relação a um ser que traz em si mesmo as condições da atividade perceptiva. Mesmo após assumir tal tese, Merleau-Ponty ainda defende, em seus últimos textos, que não é possível conceber nenhum tipo de ser sem referência à atividade perceptiva subjetiva (Cf. VI, 218, jan. 1959) ${ }^{23}$. Para entender o sentido de tal afirmação, consideremos os dois resultados mencionados acima. Comecemos pelo segundo deles (uma concepção renovada da subjetividade).

Merleau-Ponty concebe o sujeito como um foco no qual a sensibilidade do mundo se concentra e se reverte em senciência, voltando-se então sobre o próprio mundo. Os conteúdos percebidos são, assim, perspectivas sobre o ser (as quais, ao menos em condições ideais, poderiam ser assumidas por diferentes sujeitos) e não vivências privadas ${ }^{24}$. Acrescentemos a essa tese o primeiro resultado obtido por Merleau-Ponty com a noção de carne: o ser carnal (anterior à cisão entre sujeito e objeto), que se organiza como espetáculo percebido. Vimos que a subjetividade se forma com base em um ser passivo que se reverte em atividade (ela não é um fluxo de vivências fechado em si mesmo). Ao voltar-se sobre o ser, a percepção encontra estruturas sensíveis inerentes ao mundo. Quer dizer que o exercício da percepção, longe de projetar uma camada de qualidades antropomórficas sobre o mundo, capta estruturas

descobertas no campo da linguagem" (Cassou-Noguès, P. "La définition du sujet dans Le Visible et L'Invisible". In: Merleau-Ponty aux Frontières de l'Invisible. Milano: Mimesis, 2003, p.174).

${ }^{23}$ Em uma nota publicada, Merleau-Ponty chega a remeter a organização dimensional do sensível (tema de que trataremos na próxima seção) ao corpo: "mas, enquanto as coisas só se tornam dimensões quando elas são recebidas em um campo, meu corpo é esse próprio campo, i. e., um sensível que é dimensional por si mesmo, mensurador universal" (VI, 308, junho 1960). No entanto, no decorrer de sua argumentação, tal como pretendemos mostrar, Merleau-Ponty atribui ao próprio ser o papel de campo dimensional e não ao corpo. Nessa nota citada, Merleau-Ponty parece somente reafirmar o papel proeminente da sensibilidade humana, o qual tentamos explicar a seguir.

${ }^{24}$ Numa nota inédita, Merleau-Ponty critica o "erro imenso de considerar [a subjetividade] como fluxo de Erlebnisse. Ela é antes de tudo campo" (nota 1a, dezembro de 1959. Ver item f do apêndice). 
intrínsecas ao ser. É, assim, por meio da percepção que o ser do mundo se revela tal como ele é. Por conseguinte, outros tipos de ser tradicionalmente concebidos (por exemplo, o ser-objeto, conjunto de propriedades explicitadas pela matemática) são somente uma variação da forma sensível pela qual o ser do mundo se apresenta originariamente. Daí que em $O$ Visível e o Invisível, Merleau-Ponty afirme que a descrição da atividade perceptiva, tal como realizada pela Fenomenologia da Percepção, não deva ser considerada como um estudo psicológico, mas sim como caracterização ontológica do ser do mundo (Cf. VI, 228, fev. 1959) ${ }^{25}$. Dado que em si mesmo o ser é sensível, é então pela atividade perceptiva (considerada como atualização de uma perspectiva subjetiva partilhável implicada já na organização do mundo, e não como fluxo de eventos privados) que o ser se revela. Descrever a percepção é, segundo esse ponto de vista, descrever o modo pelo qual o ser do mundo se manifesta enquanto tal. Esse resultado, antes fruto da análise fenomenológica das vivências subjetivas, é confirmado pela ontologia indireta dos textos finais de Merleau-Ponty.

\section{C) A negatividade inerente ao ser}

\section{O problema da correlação perceptiva}

Acompanhamos na seção anterior como Merleau-Ponty desenvolve sua ontologia final sem depender de uma descrição direta da experiência perceptiva, mas de forma a obter resultados que legitimem a prioridade da descrição perceptiva como via para a caracterização do ser. Em uma nota inédita de 1959, o filósofo resume de maneira lapidar sua intenção: "eu busco um meio ontológico, o campo que reúna o objeto e a consciência. E isso é bem necessário se se quer sair da filosofia idealista" ${ }^{26}$. Para afastar-se da redução idealista do ser àquilo que se manifesta diretamente à subjetividade, é necessário investigar o campo do qual a própria atividade subjetiva

\footnotetext{
${ }^{25}$ Nesta nota de $O$ Visível e o Invisível, o filósofo afirma que tal papel ontológico atribuído à descrição da percepção tornar-se-ia claro se se considerasse o caráter dependente do ser estudado pela ciência (ser objetivo) em relação ao ser percebido. Num texto inédito, Merleau-Ponty desenvolve essa idéia: os objetos estudados pela ciência, "na medida em que podem ser ditos existentes, é que eles são direta ou indiretamente perceptíveis ou sensíveis" (nota 12; ver item g do apêndice). É, assim, com base naquilo que se manifesta sensivelmente que se pode conceber os entes inobserváveis descritos pelas teorias científicas. O conhecimento dos microfenômenos, por exemplo, só é possível pela aplicação da percepção humana a uma escala de objetos diferente daquela sobre a qual ela normalmente é exercida. Segundo uma nota publicada em $O$ Visível e o Invisível, "os conhecimentos em > ou < escala (macrofenômenos microfísicas) são determinação em pontilhado (por instrumentos matem., i.e., inventário de estruturas) de núcleos de ser cuja atualidade só a percepção me dá e que só podem ser concebidos por empréstimo à sua membrana" (VI, 276, junho 1960). Assim, por exemplo, embora os átomos não sejam objetos perceptíveis, os modelos pelos quais eles são concebidos (e. g., o modelo planetário do átomo, formulado por Rutherford) são baseados em estruturas compreensíveis sensivelmente.

${ }^{26}$ Nota 4; ver item h do apêndice.
} 
brota, o campo em que tal atividade é preparada e que porta suas condições mais gerais. Daí o desenvolvimento da noção de carne, camada ontológica em que certas propriedades posteriormente atribuídas aos sujeitos ou aos objetos coexistem de maneira indivisa. Como vimos, a carne exprime a idéia de que o ser que motiva e nutre a percepção já é sensibilidade iminente, já é solidário com uma perspectiva subjetiva sobre o ser. A noção de carne torna, assim, compreensível que os conteúdos percebidos não sejam meras representações psicológicas, mas apresentações dos componentes do mundo tal como eles são.

Como notamos no final do capítulo anterior, Merleau-Ponty parece, em seus textos finais, chegar às mesmas teses defendidas pela Fenomenologia da Percepção. Certamente o filósofo mudou o itinerário (abandonou a caracterização do ser por meio da descrição das vivências subjetivas e desenvolveu uma análise ontológica indireta, por meio dos resultados das ciências e artes), mas seu destino parece ter sido o mesmo. Afinal, nesses textos finais, como vemos, o ser ainda é apresentado como ser perceptível, e a percepção ainda é considerada como cânone para qualquer ser concebível. É verdade que a correlação entre ser e atividade perceptiva não está mais no início da reflexão (o ser não se define como sensível porque é percebido pelo sujeito), mas ela parece sintetizar o resultado final a que se chega (dado que o ser é sensível, então aquilo que o sujeito percebe é o ser). Se for assim, então Merleau-Ponty parece não ter avançado nada em relação à posição assumida na Fenomenologia da Percepção. E as conseqüências idealistas padecidas por essa última poderiam reaparecer e abalar sua ontologia final.

Expor uma consequiência desse tipo parece a intenção de Michel Haar ao criticar a aparente ausência de limites da noção de carne. Uma vez que Merleau-Ponty define a carne como uma camada sensível originária, da qual objetos e sujeitos decorrem, parece, por conseguinte, que todos os processos e eventos mundanos deveriam partilhar os atributos de tal camada, tal como a sensibilidade iminente. Haar se pergunta se "se deve chamar de 'sensibilidade' os processos subatômicos",27. Sua indagação tenta despertar um desconforto ante as consequiências da posição de Merleau-Ponty: atribuir sensibilidade aos componentes do mundo implicaria reconhecer que mesmo os microfenômenos são sensíveis. Essa conseqüência seria absurda, pois comumente supõe-se que em si mesmos os microfenômenos não são sensíveis e só podem ser

\footnotetext{
${ }^{27}$ Haar, M. Art. cit., p.19.
} 
estudados de maneira indireta. Ora, em nosso primeiro capítulo, tentamos expor um desconforto semelhante, gerado pelas teses da Fenomenologia da Percepção quanto aos eventos que antecederam o surgimento da vida humana na Terra. Segundo tal obra, tais eventos devem ser concebidos como construções culturais, pois tudo o que deles poderia ser mencionado são formulações teóricas que devem se conformar aos parâmetros da consciência perceptiva humana (Cf. PhP, 494). A exposição da ontologia final de Merleau-Ponty, conforme a seção anterior, parece confirmar esse resultado: nos últimos textos do filósofo, o ser é por ele mesmo sensível, de modo que a percepção apreende-o privilegiadamente, em seu modo originário. Além disso, vimos que esses mesmos textos defendem que os eventos que aparentemente excedem a percepção (micro e macrofenômenos) só podem ser compreendidos enquanto são percebidos (Cf. nota 25 deste capítulo). Enfim, Merleau-Ponty parece não reconhecer, mesmo em seus últimos anos, nenhum excesso do ser para além da sua correlação com as capacidades perceptivas humanas.

A ontologia final de Merleau-Ponty parece estar de pleno acordo com os textos fenomenológicos iniciais, e apenas fornece uma nova justificativa para os resultados obtidos inicialmente. Essa interpretação, segundo a qual há uma perfeita continuidade entre a Fenomenologia da Percepção e $O$ Visível e o Invisível, já foi defendida por alguns comentadores. Em nossa introdução, mencionamos M. C. Dillon como representante dessa linha interpretativa. Mas outros autores também partilham da mesma posição. É o caso de Henry Pietersma, para quem a doutrina ontológica esboçada nas últimas obras de Merleau-Ponty seria um complemento do estudo da percepção antepredicativa realizado na Fenomenologia da Percepção ${ }^{28}$. A análise da percepção nessa obra "projeta uma ontologia da carne" 29 , por meio da qual o ser seria concebido como aquilo que pode ser perceptivelmente acessível. Não haveria, assim, nenhuma exterioridade entre a atividade percipiente e o ser; ambos se conformariam de maneira harmoniosa. Por meio da noção de carne, Merleau-Ponty pretenderia, assim, "nos assegurar que não há outro ser senão aquele com que estamos em contato pela percepção primordial" 30 .

Defenderemos a partir de agora que a interpretação segundo a qual a última ontologia de Merleau-Ponty apenas confirma os resultados da sua ontologia

\footnotetext{
${ }^{28}$ Cf. Pietersma, H. Phenomenological Epistemology. Ed. supra, p. 151.

${ }^{29}$ Ibid., p. 128.

${ }^{30}$ Ibid., p. 178 .
} 
fenomenológica primeva é falsa e deriva de uma leitura parcial dos seus textos. Não se trata, sem dúvida, de rejeitar os resultados estabelecidos acerca da carne como ser sensível, mas de inseri-los numa renovação conceitual da própria noção de sensível, pela qual Merleau-Ponty justamente desenvolve as teses mais originais de sua última filosofia. Pretendemos expor essa renovação da idéia de sensível e, assim, explicitar que o filósofo rompe com algumas teses de sua ontologia fenomenológica inicial, particularmente com a vigência da correlação entre ser e capacidades perceptivas. Veremos, por fim, que a ontologia final de Merleau-Ponty, embora remeta em muitos pontos às teses defendidas por suas primeiras obras, compõe um quadro teórico irredutível a elas.

Segundo a leitura que Pietersma apresenta da obra de Merleau-Ponty, o ser é aquilo que aparece para um corpo senciente. No entanto, como expusemos em nosso sexto capítulo, a abertura perceptiva espontânea para o mundo (a fé perceptiva) não se limita a recolher dados positivos, mas também implica o reconhecimento de ausências originárias, de um encobrimento constituinte da experiência. Dessa maneira, o ser sensível investigado por Merleau-Ponty não é apenas um conjunto de propriedades diretamente perceptíveis; o ser sensível também comporta não-percepção, encobrimento, e, nesse sentido, explicitação daquilo que não se apresenta como conteúdo percebido, mas somente como falta ${ }^{31}$.

Merleau-Ponty obtém esse resultado por admitir uma negatividade inerente ao ser, ou seja, por reconhecer que o modo como eventos e entes existem não se reduz à pura atualidade de dados positivamente apreensíveis pela percepção. O ser inclui possibilidades internas de organização, não no sentido de alternativas lógicas abstratas, mas no sentido de latências estruturais que embora não sejam dados positivos atuais, ajudam a compor o campo da experiência ${ }^{32}$. Será ao desenvolver essa idéia de possibilidade ou negatividade inerente ao ser que Merleau-Ponty evita a redução do ser carnal ou sensível a um correlato dos poderes perceptivos ${ }^{33}$. O filósofo explora tal idéia

\footnotetext{
${ }^{31}$ Retomamos aqui a seguinte citação, já exposta no quarto capítulo: "o sensível não é somente as coisas, é também tudo o que aí se desenha, mesmo implicitamente, tudo o que aí deixa seu traço, tudo o que aí figura, mesmo a título de desvio [écart] e como uma certa ausência" (S, 217).

${ }^{32}$ Numa nota publicada em $O$ Visível e o Invisível, Merleau-Ponty associa claramente a negatividade a uma noção expandida de ser sensível, que a ontologia deve estudar: "a negatividade que habita o tocar (e que eu não devo minimizar: é ela que faz com que o corpo não seja um fato empírico, que ele tenha significação ontológica) (...) é o outro lado ou o inverso (ou a outra dimensionalidade) do Ser sensível" (VI, 303, maio 1960).

33 Numa nota inédita, Merleau-Ponty afirma: "o possível bruto, aquele dos contornos, das 'configurações', aquele das coisas 'escondidas' por outras, aquele do efeito túnel, a massa de ser que faz com que o ser não seja ser percebido” (nota 36a, agosto de 1959, ver item i do apêndice).
} 
ao menos em relação a três temas. O primeiro deles se refere à ontogênese animal: os embriões exibem certos comportamentos antes mesmo que sua base anatômica esteja suficientemente desenvolvida, como se a totalidade das funções maduras implicitamente atuasse na manutenção da vida animal em desenvolvimento. Dado que expusemos tal tópico em nosso terceiro capítulo, não o retomaremos aqui. O segundo tema se refere à noção de invisibilidade e o terceiro ao esboço de uma teoria do tempo como componente do ser e não como estrutura da existência humana. Vamos acompanhar em detalhe esses dois últimos temas a fim de completar a exposição da ontologia final de Merleau-Ponty, iniciada, na seção anterior, com a noção de carne ${ }^{34}$.

\section{A invisibilidade}

Voltemo-nos, em primeiro lugar, para a noção de invisibilidade. Em uma famosa nota de $O$ Visível e o Invisível, Merleau-Ponty enumera diferentes sentidos em que se usa o termo "invisível”: a) algo não visível atualmente, mas de direito acessível à visão; b) as dimensões do campo visível; c) o que só se manifesta para o tato ou por meio dos movimentos cinestésicos em geral; d) os lekta ${ }^{35}$ e o cogito (Cf. VI, 305, maio 1960). Deve-se notar que o primeiro sentido de invisível aí enumerado é frequentemente tratado por Merleau-Ponty como um homônimo que de modo algum exprime a sua intenção em elevar a invisibilidade a conceito filosófico. Por sua vez, tal intenção é desenvolvida pelo filósofo em relação aos sentidos b e d (quanto ao item c, o filósofo parece somente mencionar os dados perceptivos que não são obtidos pela visão. Esse uso de "invisível" não contribui com a tese da irredutibilidade do ser ao ser percebido, já que, obviamente, tal uso ainda implica que o ser está em correlação com os outros sentidos da percepção humana, excluída a visão). Em termos gerais, a intenção filosófica de Merleau-Ponty é reformular certas dualidades, aparentemente intransponíveis, herdadas da tradição filosófica (por exemplo, corpo/alma,

\footnotetext{
${ }^{34}$ Renaud Barbaras expõe como a tese acerca da negatividade inerente ao ser se desenvolve com base na crítica bergsoniana à tradição metafísica. Segundo tal crítica, a tradição filosófica concebe o ser como pura positividade, que resiste a um estágio de não-ser supostamente anterior à existência do mundo. Ora, essa concepção seria injustificada, pois o ser deve ser abordado nele mesmo e não como algo perfilado sobre a hipótese de um nada anterior. Segundo Barbaras, Merleau-Ponty extrai dessa crítica a idéia de dimensões negativas intrínsecas ao ser: abordado sem o pressuposto de um nada prévio que ele viria superar, o ser "não exige mais a positividade que somente o nada impunha a ele e pode portanto comportar uma dimensão de negatividade" (Barbaras, R. "Le Tournant de l'Expérience - Merleau-Ponty et Bergson”. In: Le Tournant de l'Expérience. Recherches sur la Philosophie de Merleau-Ponty. Ed. supra, p.50).

${ }^{35}$ Termo da epistemologia estóica que indica os "dizíveis", isto é, as expressões lingüísticas pelas quais os pensamentos se referem às coisas.
} 
fato/essência), de modo que a sua reconceitualização por meio da oposição visível/invisível dissolva a incomensurabilidade entre os termos em questão. Numa nota inédita de 1958, Merleau-Ponty esclarece o poder heurístico de sua nova terminologia: “o espírito ou a consciência excede o corpo fenomenal emergindo (emergente) no invisível. Há aí um certo dualismo, incontestável. Mas esse dualismo não significa duas substâncias: significa apenas um certo desnível da significação apontando para fora da massa sensível"36. Concebidas com base na oposição visível/invisível, as noções de alma e de corpo não se opõem como diferentes substâncias por princípio incomunicáveis. Aquilo que é tratado como invisível remete ainda ao visível como seu inverso e não se apresenta como algo plenamente independente da visibilidade, o que exclui o dualismo substancial ${ }^{37}$.

O campo temático em que Merleau-Ponty melhor desenvolveu as relações entre visibilidade e invisibilidade foi aquele referente às dimensões da experiência visual (item b enumerado no parágrafo anterior). O filósofo defende que nenhum ente visível é um objeto cujo ser se esgota em sua manifestação atual. Já na própria visibilidade há uma invisibilidade atuante, que não se reduz ao fato de que existem perspectivas ou aspectos que não são visíveis atualmente mas poderiam sê-lo sob outras condições ${ }^{38}$. O que é então essa invisibilidade presente na visibilidade? Trata-se daquilo que MerleauPonty denomina dimensões, sistemas de ordenação pelos quais os entes visíveis particulares podem ser vistos. Para o filósofo, o mundo sensível não se reduz a um conjunto de entes ou processos individuais, uma vez que tais individualidades são organizadas conforme certos padrões gerais de familiaridade. Esses sistemas não são objetos, mas matrizes pelas quais a percepção desses objetos se torna possível. Deve-se notar que, segundo Merleau-Ponty, tais matrizes não são formadas por componentes diferentes daqueles que constituem os entes particulares. Quer dizer que as dimensões, que excedem a estrita correlação entre a atividade perceptiva e os dados positivamente apreendidos, não são algo absolutamente estranho ao ser sensível apresentado pela

\footnotetext{
${ }^{36}$ Nota $26 b$, ver item j do apêndice.

37 "O invisível não é o contraditório do visível: o próprio visível tem uma membrana de invisível e o invisível é a contrapartida secreta do visível" (VI, 265, nov. 1959). No prefácio de Signes, Merleau-Ponty volta a expor as vantagens epistemológicas da sua terminologia, dessa vez em relação aos conceitos fundamentais da filosofia de Sartre: "antes do ser e do nada, seria melhor falar do visível e do invisível, repetindo que eles não são contraditórios" (S, 30). Deve-se notar que Merleau-Ponty não pretende assumir um monismo substancial ao apontar a mútua dependência entre o visível e o invisível (Cf. nota $26 b$, item j do apêndice). O desnível entre visível e invisível significa, na verdade, que ambos são como diferentes ordens emergentes, as quais, embora correlacionadas, são irredutiveis entre si.

38 "O invisível não é um outro visível ('possível' no sentido lógico), um positivo somente ausente" (VI, 300, maio 1960)
} 
percepção, não são parte de um em-si formado por qualidades objetivas independentes da sensibilidade. Na verdade, as dimensões são formadas por componentes sensíveis também encontrados nos entes, embora em uma função diferente, a saber, aquela de propriedade geral pela qual todo um campo de indivíduos se arranja. Assim, a dimensão surgiria da generalização dos componentes sensíveis, tornados então matrizes de organização do campo, e não mais atributos individuais. Daí que, como afirmamos há pouco, os entes visíveis não sejam pura positividade: seus aspectos sensíveis comportam uma latência estrutural, eles podem se generalizar e se tornar níveis inaparentes pelos quais as coisas aparecem.

Segundo Merleau-Ponty, não há incompatibilidade entre o caráter particular e geral do mesmo atributo sensível: "é precisamente no interior da sua particularidade de amarelo e graças a ela que o amarelo se torna um universo ou um elemento" (VI, 267, nov. 1959), exemplifica o filósofo. A generalidade seria uma função imanente ao sensível, conforme alguns de seus componentes assumam o papel de um elemento, no sentido de um princípio pré-individual que participa da constituição de diversos entes particulares. Essa tese de que os entes individuais são atravessados por possibilidades de generalização (quer dizer, de que nenhum ente se esgote em sua particularidade, mas participe de dimensões que excedem seu caráter singular) indica, como bem nota Étienne Bimbenet, que não há uma distinção cerrada entre o ser e os entes na filosofia de Merleau-Ponty. Segundo Bimbenet, "para Merleau-Ponty o ser se descobre menos em sua diferença ontológica com o ente que na diferença do ente consigo próprio; menos em seu movimento para a fenomenalização que no movimento dos próprios fenômenos, ou com os fenômenos como movimento, iminência, potência de outros fenômenos ainda" 39 . O ser, no sentido geral, não é, assim, um princípio distinto dos entes, mas o caráter dimensional inerente aos próprios entes.

O exemplo mais desenvolvido de Merleau-Ponty sobre o sensível dimensional é o da cor amarela: tal cor pode ser atributo de um ente visível, mas também realizar a função de cor da iluminação geral de um ambiente. Nessa última função, acredita Merleau-Ponty, a cor se torna um meio inaparente (que não se doa positivamente à sensibilidade humana) pelo qual os fenômenos são ordenados (Cf. VI, 267, nov. 1959). Os sujeitos perceptivos comumente apreendem a cor amarela como atributo de diversos entes particulares, mas não podem apreender, julga o filósofo, a função dimensional

\footnotetext{
${ }^{39}$ Bimbenet, E. Nature et Humanité. Ed. supra, p.242.
} 
pela qual um campo sensível é ordenado pela cor amarela. Essa função é invisível, no sentido que Merleau-Ponty atribui ao termo: um princípio geral que atua na organização do campo sensível ${ }^{40}$.

Passemos agora a considerar a temática da invisibilidade aplicada ao domínio das significações lingüísticas e do pensamento em geral (Cf. item d da nota publicada em VI, 305), considerado então como o outro lado da sensibilidade. Esse outro lado não deve ser concebido como um mundo inteligível, mas como uma dimensão, um princípio de equivalência que se mantém enraizado no sensível, mas dele se diferencia (Cf. VI, 263, out. 1959). Esse enraizamento implica que ao menos algumas funções intelectuais se originam do caráter dimensional do mundo sensível. Vimos que os entes sensíveis individuais são organizados conforme certas propriedades assumem o papel de dimensões gerais do mundo sensível. A experiência perceptiva, que supõe a organização do campo sensível por meio de dimensões gerais, parece servir de base, crê o filósofo, para o posterior desenvolvimento da capacidade cognitiva de subsumir termos particulares a classes ou idéias puramente intelectuais. É como se a gênese de tais capacidades lógicas se encontrasse na imersão do sujeito humano em um sensível dimensional, em que as coisas participam de princípios de equivalência que as excedem e as ordenam ${ }^{41}$. É verdade que a dimensão sensível está sempre ligada aos domínios fenomenais que organiza (embora não se reduza a dados positivos, pois é justamente o caráter transcendente dos dados, ou seja, o excesso ontológico irredutível à pura presença atual). Por sua vez, as idéias, não partilham de um lastro sensível com os termos subsumidos; elas são não-temporais, não-espaciais (Cf. VI, 255, nov. 1959) e não participam daquilo que é por elas ordenado ${ }^{42}$. Mesmo com tal diferença entre o sensível e as idealidades, a operação realizada por essas últimas de subsumir termos

40 Como Merleau-Ponty não dá mais nenhum exemplo de atributos sensíveis generalizáveis, fica a questão de saber se apenas as cores são dimensionais. Numa nota, o filósofo menciona que a percepção apreende não entes individuais absolutos, mas "coisas que são dimensões, que são mundos" (VI, 267, nov. 1959). Nessa nota, não é claro se ele se refere apenas às cores de que as coisas são compostas ou à totalidade de atributos sensíveis das coisas. Caso se trate dessa última alternativa, seria necessário esclarecer melhor de que maneira outros componentes sensíveis, tais quais as formas ou o peso por exemplo, podem funcionar como matrizes pelas quais todos os outros objetos são organizados.

${ }^{41}$ Numa nota inédita, Merleau-Ponty afirma que "as percepções do visível são já percepções do invisível: a cor se tornando invisível quando ela passa a nível. O espírito, o conceito, o espiritual não são nada mais que esta estrutura remanejada, reconstruída pela linguagem" (nota n.7, fevereiro 1960, ver item m do apêndice).

${ }^{42}$ Tal como Husserl exprime de forma lapidar ao criticar a noção de idéia geral abstrata de Locke: "um triângulo é algo que tem triangularidade. Porém, a triangularidade não é nela mesma algo que tenha triangularidade" (Husserl, E. Logische Untersuchungen. Coleção Husserliana, XIX/1. The Hague, Martinus Nijhoff, 1984, p.139). Assim, o conceito pelo qual se define "triângulo" não é um triângulo e, de maneira geral, tese aceita por Merleau-Ponty, as idéias são de uma ordem diferente daquilo que é subsumido por elas. 
particulares derivaria, segundo Merleau-Ponty, da organização dimensional do sentir. Essa organização funcionaria como uma idealidade primitiva inscrita no interior do mundo sensível, uma dimensão invisível que sustenta o desenvolvimento das funções do pensamento ${ }^{43}$.

Tentamos, nos parágrafos anteriores, exibir a amplitude do escopo temático almejado por Merleau-Ponty com a noção de invisibilidade. Longe de se limitar ao estrito campo da percepção visual, essa noção se torna um conceito funcional pelo qual é possível renovar a análise filosófica de diferentes tópicos. Numa nota inédita de 1958, o filósofo anuncia: "a guerra, a história, o social, os seres culturais, como seres invisíveis"44. Em todos esses casos, tratar-se-ia de buscar "o não-ser sobre o qual se apóia todo o ser de nossa vida histórica"45, quer dizer, as matrizes inaparentes pelas quais os eventos da história humana se organizam ${ }^{46}$. Merleau-Ponty almejava, assim, estender a investigação das dimensões inaparentes de organização dos entes ou eventos para todos os domínios da existência humana. Vale notar que o filósofo chega, de fato, a esboçar uma análise do contato com outrem em termos da oposição visível/invisível. Segundo tal análise, cada sujeito vê o corpo do outro, mas não apreende diretamente seu nível ou dimensão invisível (sua consciência e sua experiência). No entanto, esse nível se doa, ainda que como ausência, juntamente com o corpo de outrem ${ }^{47}$. A vida invisível de outrem só é assimilada de modo indireto, uma vez que todos os sujeitos se dirigem ao mesmo mundo sensível e, por meio desse campo partilhado, podem apreender as intenções alheias ${ }^{48}$.

Importa notar, por fim, que Merleau-Ponty concebe a noção de invisibilidade como uma armadura geral de sentido que transcende os eventos e coisas particulares, e que seria responsável pela organização destes. Por meio dessa noção de invisibilidade, o filósofo pretendia elaborar um esquema ontológico global, pelo qual os mais diversos campos da vida humana poderiam ser caracterizados para além do seu caráter

\footnotetext{
${ }^{43}$ No quarto capítulo, expusemos com mais detalhes como atua essa idealidade primitiva ou sensível.

${ }^{44}$ Nota $24 \mathrm{~b}$, ver item $\mathrm{n}$ do apêndice.

${ }^{45}$ Id., ibid.

${ }^{46}$ A mesma intenção é retomada numa nota publicada em $O$ Visível e o Invisível. "Pôr a questão: a vida invisível, a comunidade invisível, outrem invisível, a cultura invisível" (VI, 278, jan. 1960).

${ }^{47}$ Numa nota inédita de janeiro de 1959, Merleau-Ponty afirma: "outrem é o ser não Urpräsentierbar [apresentável originariamente], que não é suscetível de ser ele mesmo dado sem médium interposto, mas isso ele o é absolutamente: ele é dado como o que não é originariamente doável" (nota 92a, ver item 1 do apêndice).

48 "A sensibilidade dos outros é 'o outro lado' de seu corpo estesiológico. E esse outro lado, nichturpräsentierbar, eu posso adivinhá-lo pela articulação do corpo de outrem sobre o meu sensível" (VI, 282, jan. 1960).
} 
factualmente positivo, mas sem que esse excesso signifique reatar com um dualismo ontológico.

\section{Uma nova teoria do tempo}

O terceiro tema pelo qual Merleau-Ponty atribui uma espessura ao ser que escapa à apreensão direta da consciência é aquele do tempo. Na Fenomenologia da Percepção, o tempo, concebido como uma passagem entre diferentes dimensões (futuro, presente e passado), era apresentado como uma estrutura da existência humana. No mundo considerado em si mesmo, só haveria um eterno presente sem densidade temporal $^{49}$. Vimos, em nosso primeiro capítulo, que essa tese, reunida à concepção de ser em termos de propriedades subjetivamente apreensíveis, impedia Merleau-Ponty de apreender o passado do mundo como tal. A atribuição de um passado ao mundo era feita de maneira figurativa, já que os eventos mundanos, considerados em si mesmos, deveriam ser, segundo o livro de 1945, sempre presentes. Qualquer sucessão entre tais eventos seria apenas uma constatação que, de algum modo, deveria se referir à subjetividade humana, a qual, naquele livro, era identificada ao próprio tempo ${ }^{50}$.

Numa nota inédita, Merleau-Ponty sustenta que "a subjetividade é tempo - mas nem todo tempo é subjetividade" ${ }^{51}$. Assim, em seus anos finais, o filósofo não deixa de considerar que subjetividade e temporalidade estão intimamente ligadas e mesmo (em um certo nível) identificadas, mas recontextualiza tal consideração. Na Fenomenologia da Percepção, a subjetividade era responsável pela atribuição do caráter temporal aos eventos do mundo. Em seus últimos anos, Merleau-Ponty abandona essa tese; a subjetividade ainda será considerada tempo, mas por estruturar-se sobre um tempo que se origina no próprio ser sensível. Além disso, o modo como a subjetividade recolhe tal tempo será descrito de uma maneira diferente daquele pelo qual tal subjetividade vivenciava o tempo de acordo com a Fenomenologia da Percepção.

No livro de 1945, Merleau-Ponty rejeita a concepção temporal linear (sucessão de instantes fechados em si mesmos) em favor da descrição husserliana da passagem do

\footnotetext{
49 “O tempo não é um processo real, uma sucessão efetiva que eu me limitaria a registrar. Ele nasce de minha relação com o mundo (...). Se destacamos o mundo objetivo das perspectivas finitas que abrem sobre ele e se o pomos em si, em todas as suas partes só podemos encontrar 'agoras'. Mas ainda, esses agoras, não estando presentes a ninguém, não têm nenhum caráter temporal e não poderiam suceder-se" $(\mathrm{PhP}, 471)$.

50 “'A passagem do presente a um outro presente, eu não a penso, eu não sou seu espectador, eu a efetuo, eu já estou no presente que virá como meu gesto já está em sua meta, eu sou eu mesmo o tempo, um tempo que 'permanece', não 'se escoa' nem 'muda'” ( $\mathrm{PhP}, 481-2)$.

${ }^{51}$ Nota 54a, maio 1959, ver item o do apêndice.
} 
tempo. Segundo tal descrição, a experiência temporal não é de momentos discretos, mas de um campo de presença, quer dizer, de uma zona temporal densa que envolve uma abertura tanto para o passado imediato (retenção) quanto para o futuro próximo (protensão). Ainda segundo tal concepção, quando os instantes densos que formam tal campo decaem no passado, eles são visados de maneira modificada através do novo instante presente. Assim, por exemplo, o instante denso A, uma vez passado, é retomado como A' em relação ao instante presente B. Quando B se torna passado, esse instante é retomado como B' em relação a C. Por sua vez, o instante A aparece modificado como A'" em relação a $\mathrm{C}$, já que é visado não só como passado, mas como passado por intermédio de um outro instante passado, $\mathrm{B}^{52}$.

Não é difícil notar, entretanto, que apesar de não se identificar com a sucessão de instantes pontuais, a descrição husserliana supõe ainda uma seqüência sucessiva, de campos de presença ou instantes densos, e, nesse sentido, poderia ainda ser classificada como serial. A fim de enfraquecer tal caráter serial, Merleau-Ponty, na Fenomenologia da Percepção, sustenta que a descrição do campo de presença como sucessão de instantes é somente uma descrição parcial da experiência do tempo. Na verdade, se se desvela a temporalidade constituinte, ou seja, a temporalidade verdadeiramente originária da consciência, então não há uma multiplicidade de instantes densos (A, B, C) ordenados sucessivamente, mas um único movimento de escoamento, no qual as diferentes dimensões (passado, presente e futuro) se recobrem como um ímpeto generalizado, sem a distinção de momentos discretos (Cf. PhP, 479-482). Esse apelo a uma temporalidade constituinte una não significa a rejeição da idéia de uma multiplicidade sucessiva de instantes. Tal multiplicidade será o tempo constituído por aquele ímpeto indiviso originário. No entanto, esse tempo constituído não exerce um papel meramente secundário, embora, de fato, seja o termo fundado pelo tempo constituinte (que é então o termo fundante). Mas nas relações de fundação, tais como descritas por Merleau-Ponty, o termo fundado é o responsável pela manifestação do fundante, de modo que há circularidade entre ambos, e não precedência causal de um em relação a outro. Assim, no que se refere ao tempo, são os instantes distintos que permitem o reconhecimento do fenômeno geral de passagem (Cf. $\mathrm{PhP}, 484$ ), de maneira que a multiplicidade sucessiva é o modo pelo qual o escoamento temporal se explicita.

\footnotetext{
52 "O que me é dado é A visto por transparência através de A', depois esse conjunto através de A" e assim por diante, como eu vejo o próprio seixo através das massas d'água que escorrem sobre ele" (PhP, 478).
} 
Em seus textos finais, Merleau-Ponty sustenta, tal como em sua obra anterior, que a descrição husserliana do tempo não é uma descrição serial simples, pois apresenta a formação de uma rede de instantes densos, em que cada um é visado não como um ponto idêntico, mas como uma manifestação que se perfila conforme sua posição na camada cumulativa de instantes vividos (Cf. VI, 245, maio 1959). No entanto, não encontramos mais o apelo a um tempo subjetivo constituinte, o qual matizaria ainda mais o caráter serial implícito na descrição husserliana. Nesses textos, tal descrição do tempo é tratada, no geral, como uma concepção serial, ainda que complexa, do tempo. Conforme tal concepção, o tempo seria uma passagem de instantes ao qual se opõe um foco de consciência imóvel, que retém sucessivamente os elementos de tal escoamento. Essa idéia de que a experiência temporal é uma série de campos de presença progressivamente vividos e retidos será criticada por Merleau-Ponty.

Em suas notas inéditas, o filósofo lamenta que a concepção do tempo serial tenha sido elevada pela tradição à condição a priori de qualquer experiência. Se o tempo serial assume esse papel, então as demais temporalidades registradas pela antropologia (o tempo cíclico, por exemplo) são reduzidas a conteúdos psicológicos já previamente organizados de maneira serial ${ }^{53}$. No entanto, para Merleau-Ponty, o tempo serial não é uma condição sem a qual não haveria nenhuma experiência do tempo, mas sim uma construção cultural, a qual nem mesmo abarca componentes fundamentais da experiência do tempo ${ }^{54}$. A fím de argumentar em favor dessa tese, o filósofo discute o fenômeno do esquecimento, o qual não seria adequadamente explicado pela concepção serial.

Segundo Merleau-Ponty, a principal característica do esquecimento é sua descontinuidade. Não ocorre que o fluxo temporal acumule instantes vividos em uma progressão contínua que em certo ponto desaparecia no esquecimento. Tal como nota o filósofo, alguns instantes vividos há longa data permanecem fortemente retidos, enquanto muitas experiências recentes são logo esquecidas (Cf. VI, 245, maio 1959). Não há uma correspondência entre os instantes vividos e aqueles esquecidos do seguinte tipo: os instantes mais antigos são progressivamente esquecidos e os mais novos são armazenados gradualmente até o esquecimento. Não é assim que a experiência ocorre, constata Merleau-Ponty. Conforme assevera uma nota inédita, uma lembrança "não é

\footnotetext{
${ }^{53}$ Cf. nota 26, 1958; ver item $\mathrm{p}$ do apêndice.

${ }^{54}$ Tal como o filósofo afirma em uma nota inédita, "essa referência ao tempo ocidental - cartesiano como termo de uma alternativa cujo outro [termo] é nada de pensamento e de ser é precisamente a ilusão das ilusões" (nota 4b, 1958; ver item q do apêndice).
} 
um Erlebnis individual reunido por retenção de retenção em sua singularidade" ${ }^{55}$. O diagrama temporal de Husserl implicava que um instante retido A só poderia ser retomado, do ponto de vista do instante presente C, como A', ou seja, como uma manifestação perfilada através do instante retido B. Segundo Merleau-Ponty, a experiência do esquecimento deve nos levar a rejeitar essa concepção de contínua progressão e contínuo acúmulo da experiência temporal. Muitas vezes, o instante A parece ser lembrado diretamente pelo instante presente $\mathrm{C}$, sem a interpolação de $\mathrm{B}$, quer dizer, sem a interferência de todos os instantes vividos entre o instante retido em questão e o presente. Para Merleau-Ponty, a concepção serial do tempo, mesmo em sua variante husserliana, não explica tal descontinuidade e não pode, portanto, ser considerada como condição a priori de toda experiência temporal. Essa concepção deve ser tomada, juntamente com a concepção cíclica registrada pela antropologia, como uma interpretação cultural da experiência do tempo e não como explicitação da sua estrutura universal $^{56}$.

Merleau-Ponty esboça uma descrição da experiência temporal (ou seja, do modo como a subjetividade é tempo) independentemente das interpretações culturais comumente atribuídas a ela. O filósofo mantém do diagrama temporal husserliano o fato de que o tempo se autoconstitui, ou seja, de que a subjetividade não é autora do tempo, mas somente vivencia um fluir originário e a ele opõe uma intencionalidade retensiva (a qual, como vimos na discussão do esquecimento, não é uma intencionalidade homogeneamente referida a todos os instante vividos). Dessa maneira, não se trata de dizer que o tempo é consciência, mas sim que a consciência, por meio da automanifestação do tempo, organiza-se como um fluxo temporal ${ }^{57}$. E essa ordenação temporal da experiência subjetiva se reflete em todas as vivências. Daí Merleau-Ponty afirmar, por exemplo, que a consciência presente é matriz simbólica, ou seja, um princípio de organização do pensamento (Cf. VI, 243, maio de 1959). No entanto, a ordenação geral da vida subjetiva por meio do tempo não implica que esse último seja uma estrutura decorrente da existência humana. Além disso, Merleau-Ponty insiste em que a consciência subjetiva não se constitui como um foco imóvel por onde escorre

\footnotetext{
${ }^{55}$ Nota 1a, dezembro de 1959; ver item f do apêndice.

${ }^{56}$ Numa nota inédita, Merleau-Ponty acentua o papel da linguagem na elaboração da concepção serial do tempo: "o tempo serial, a ordem 'objetiva' das lembranças é construção e sedimentação pela linguagem e pelas marcas de referência [repères], é idealização" (nota 51, 16/06/59; ver item $\mathrm{r}$ do apêndice).

57 Merleau-Ponty comenta em uma nota inédita: “dizendo que o tempo é Selbsterscheinung [automanifestação], Husserl não diz que ele é 'consciência', mas que a 'consciência' é fluxo" (Nota 51, 16/06/59, ver item $\mathrm{r}$ do apêndice).
} 
progressivamente uma série temporal. Na verdade, a consciência do tempo brota como diferenciação (Cf. VI, 242, maio 1959) em relação a um processo dela independente. Vejamos com mais detalhe o que significa tal tópico.

Merleau-Ponty defende que, ao menos originariamente, o tempo não é um fluxo de passagem sempre em referência à existência humana. $\mathrm{O}$ tempo se autoconstitui e a existência humana se temporaliza como que seguindo um processo que a antecede. Dessa maneira, não é o tempo que se organiza em relação à subjetividade, mas o contrário, ou seja, a subjetividade se estrutura em relação ao fluir temporal. Essa tese implica inverter a perspectiva assumida pela Fenomenologia da Percepção. Essa inversão se torna clara na tentativa de Merleau-Ponty relativizar a concepção do passado como modificação do presente e, por conseguinte, de atribuir uma espessura própria aos eventos passados ${ }^{58}$. A Fenomenologia da Percepção defendia que mesmo o passado longínquo só poderia ser considerado como evento temporal por ter sido anteriormente um presente de uma vida humana ${ }^{59}$. Não haveria, assim, nenhuma autonomia do passado, quer dizer, nenhum passado que não tenha surgido como modificação de alguma experiência temporal presente. Essa tese é abandonada por Merleau-Ponty em seus anos finais. Para tanto, o filósofo considera uma simultaneidade entre passado e presente, que a análise intencional do tempo, tal como desenvolvida no livro de 1945 , não consegue apreender. Essa simultaneidade não se comprova somente na experiência descontínua do esquecimento (segundo a qual há vivências antigas que continuam ativas mesmo se lembranças mais recentes se apagam), mas aparece principalmente no contato geral do sujeito perceptivo com o mundo. A subjetividade humana não se relaciona, segundo esse novo ponto de vista, com um mundo plenamente presente, cujas manifestações parciais seriam retidas como vivências passadas. Há um passado do próprio mundo, que não resulta de uma modificação da consciência presente, mas exprime um desenrolar interno ao próprio ser. Segundo Merleau-Ponty, "é a Bewusstsein von [consciência de], o ter percebido, que é levado pelo passado como ser maciço. Eu o percebi porque algo ocorrera" (VI, 292-3, abril 1960). Assim, a experiência perceptiva responde a um ser que não se mantém num eterno presente, tal

\footnotetext{
${ }^{58}$ Segundo Franck Robert, Merleau-Ponty pretende "pensar a presença de um passado que não seja presença de um antigo presente, quer dizer, que não seja definido a partir de uma vivência da consciência que não seria mais" (Robert, F. Phénoménologie et Ontologie. Merleau-Ponty lecteur de Husserl et Heidegger. Ed. supra, p.328).

59 "O passado mais distante tem, ele também, sua ordem temporal e uma posição temporal em relação ao meu presente, mas enquanto ele mesmo foi presente, enquanto ele foi 'em seu tempo' atravessado por minha vida e enquanto ela prosseguiu até agora" (PhP, 475).
} 
como sustentava a Fenomenologia da Percepção, e a experiência atual é simultânea a uma massa de ser cujo caráter passado não é atribuído pela subjetividade ${ }^{60}$.

É possível compreender agora a tese de Merleau-Ponty segundo a qual a subjetividade surge como diferenciação em relação a um tempo que a excede. A subjetividade humana se estabelece como um desvio, como um nível estrutural particular em relação a uma massa de ser passado (que continua a se autoconstituir de maneira autônoma) que a consciência presente se limita a recolher. Em relação a essa massa temporal passada, o sujeito aparece como um ponto móvel (e não como um foco imóvel por meio do qual as dimensões do tempo se constituem) ${ }^{61}$. O passado não é assim algo progressivamente constituído pela consciência presente. Pelo contrário, a consciência se aproxima e se afasta de camadas passadas autônomas, e constitui sua experiência como uma ordem de diferenciações em relação a um campo temporal que, em sua totalidade, escapa-lhe como mais uma dimensão invisível do ser.

Segundo Merleau-Ponty, o estabelecimento da experiência temporal humana em relação à massa temporal autoconstituinte pode receber diferentes interpretações culturais: as concepções cíclica ou serial do tempo, como vimos há pouco, são modos pelos quais os sujeitos tentam exprimir o processo de diferenciação temporal que molda a subjetividade como tempo. Deve-se notar que essa diversidade cultural não implica a admissão de que há diversos tempos incomensuráveis entre si. Para Merleau-Ponty, conforme uma nota inédita, existe um "tempo universal, que só encontra na temporalidade do para-si uma réplica e não seu fundamento"62. Os tempos serial e cíclico são, assim, reconstituições tardias da experiência temporal, conforme os instrumentos culturais disponíveis; ambos supõem um mesmo processo temporal de fundo, o qual justamente tais reconstituições tentam esquematizar.

\footnotetext{
${ }^{60}$ Franck Robert comenta a originalidade da tese de um passado inerente ao mundo ante a analítica husserliana do tempo: "do ponto de vista de Merleau-Ponty, o que faz o sentido do passado enquanto tal não é, portanto, uma diferença noética própria à consciência do tempo entre uma consciência do presente e uma consciência do passado: não é um mesmo noema que eu visaria uma primeira vez segundo uma consciência do presente e uma outra vez segundo uma consciência do passado" (Robert, F. op. cit., p.334).

${ }^{61}$ Em uma nota inédita, Merleau-Ponty afirma: "o passado próximo me parece afastar-se. O passado distante não se move mais e sou eu que me afasto dele" (nota 41, 14/06/59; ver item s do apêndice). Vale notar que a Fenomenologia da Percepção já antecipa essa noção de sujeito móvel ante dimensões fixas do tempo: "se o começo do meu dia já se afasta, o começo da minha semana é um ponto fixo" (PhP, 480). No entanto, ali, Merleau-Ponty se dedica a desenvolver a idéia da consciência presente como uma forma permanente em relação à qual os instantes fluem (Cf. $\mathrm{PhP}, 482)$.

${ }^{62}$ Nota 65b, 1959; ver item t do apêndice.
} 
Como se vê, em seus anos finais, Merleau-Ponty admite um tempo independente da experiência subjetiva temporal ${ }^{63}$. Conforme afirma uma nota inédita, "é verdadeiramente o ser que se temporaliza e não eu que acrescento o tempo ao ser como condição de sua Gegenständigkeit [caráter objetivo]"64. Para exprimir a idéia de uma atividade temporal intrínseca ao mundo, e, no geral, de uma intencionalidade inerente ao ser, o filósofo usa o termo "turbilhão" (Cf. VI, 280, janeiro 1960; VI, 293, abril 1960) $\mathrm{Na}$ verdade, esse termo não exprimiria apenas uma autoconstituição temporal do ser, mas o desenvolvimento espaço-temporal da carne do mundo. Em uma nota de $O$ Visível e o Invisível, esse tópico é explicitado: "é necessário tomar como primeiro não a consciência e seu Ablausfphänomen [fenômeno de decurso] com seus fios intencionais distintos, mas o turbilhão que esse Ablaufsphänomen esquematiza, o turbilhão espacialiante-temporalizante (que é carne e não consciência diante de um noema)" (VI, 293, abril 1960). O turbilhão indicaria os processos de diferenciação espaço-temporal, pelos quais a camada sensível do ser se atualizaria.

\section{O ser percebido e o ser sensível}

Infelizmente, Merleau-Ponty não maturou suficientemente sua nova concepção de tempo. Não é possível compreender adequadamente sua tese acerca do turbilhão de que o tempo se originaria ou sua doutrina acerca da diferenciação pela qual a temporalidade subjetiva se constitui. No entanto, o esboço legado aos leitores contemporâneos ao menos deixa clara a intenção de "dessubjetivar" o tempo, ou seja, de mostrar que em sua ordenação originária, o tempo não é um ímpeto indiviso que se confunde com a existência humana, mas que essa apenas erige uma temporalidade derivada de uma deiscência espaço-temporal inerente ao $\operatorname{ser}^{65}$. Esse movimento argumentativo é análogo àquele de enraizar as condições da sensibilidade humana no mundo sensível (por meio da noção de carne). Nos dois casos, Merleau-Ponty acentua os componentes autônomos do ser em contraposição ao papel central atribuído ao sujeito perceptivo pela Fenomenologia da Percepção.

Nas duas últimas subseções, buscamos expor o papel complementar das noções de tempo e invisibilidade em relação à idéia de carne sensível. Tal complementação

\footnotetext{
${ }^{63}$ Deve-se notar que não se trata do tempo objetivo estudado pela ciência. Merleau-Ponty pretende descrever "um tempo pré-objetivo e pré-subjetivo" (Nota 2b, 1958; ver item p do apêndice).

${ }^{64}$ Nota 14b, 27/10/58; ver item u do apêndice.

${ }^{65} \mathrm{Em}$ seus textos finais, Merleau-Ponty parece abandonar a idéia de que o tempo constituinte (que funda a multiplicidade sucessiva temporal) seja um atributo da existência humana, tal como a Fenomenologia da Percepção defendia.
} 
explicita que o ser sensível, na última filosofia de Merleau-Ponty, não é composto somente por dados positivamente apreensíveis pelas capacidades perceptivas humanas, mas também por latências inesgotáveis, as quais podem ser reconhecidas seja como um passado que em muito excede a consciência subjetiva do tempo seja como dimensões invisíveis pelas quais os entes mundanos aparecem como tais.

Notemos que na Fenomenologia da Percepção, Merleau-Ponty defendia que o mundo não era temporal, pois, tomado em si mesmo, deveria ser considerado como pleno e não poderia, assim, abrigar os desníveis de não-ser pelos quais o passado e o futuro se organizam em relação ao presente (Cf. $\mathrm{PhP}, 471)$. Segundo essa concepção, toda negatividade, ou seja, toda dimensão de ausência ou de excesso em relação à atualidade mundana deveria ser remetida à subjetividade. Nos seus textos finais, Merleau-Ponty rompe com essa idéia e passa a considerar uma negatividade inerente ao ser, o qual não se reduz, então, a uma somatória de tudo o que positiva e atualmente existe. Dessa maneira, a suspeita de Michel Haar, segundo a qual Merleau-Ponty teria universalizado indevidamente a sensibilidade inerente ao ser não se confirma ${ }^{66}$. É na verdade a transcendência ou a profundidade, entendidas como excesso dimensional que não se esgota na aparição dos entes individuais, as marcas distintivas do ser bruto. Esse excesso dimensional ontológico em relação às capacidades perceptivas significa que o modo de ser daquilo que existe não se reduz ao ser perceptível: há infra-estruturas ontológicas as quais se ocultam ante as capacidades perceptivas e, no entanto, fazem parte do campo sensível, pois são as responsáveis pela organização dos entes percebidos ${ }^{67}$.

\footnotetext{
${ }^{66}$ Segundo a interpretação de Merleau-Ponty por Haar, "no essencial, a carne não é absolutamente invisível já que ela é o Visível, o Tangível" (Haar, M. Art. cit., p.32). Haar ignora assim a ampliação da idéia de sensível, pela qual Merleau-Ponty inclui a transcendência dimensional como componente do ser sensível.

${ }^{67}$ Renaud Barbaras, Franck Robert e G. B. Madison hesitam em reconhecer esse excesso do ser em relação ao ser perceptível na ontologia final de Merleau-Ponty. Por um lado, Barbaras afirma que "o mundo sensível não pode ser confundido com o visível enquanto tal, com o universo da percepção como experiência de uma exterioridade efetiva. Se é verdade que só há o mundo, esse não poderia ser restrito ao puro visível; se é verdade que a carne é universal, ela não deve ser reduzida à carne estritamente corporal" (Barbaras, R. De l'Être du Phénomène - sur l'ontologie de Merleau-Ponty. Ed. supra, p.274). No entanto, por outro lado, esse autor assevera que "a carne é bem sinônimo da visibilidade, que é o ser de todo ser: não há ser que recue aquém de sua manifestação, que não possa se oferecer a uma visão" (Ibid., p.186). Já Franck Robert também reconhece, por um lado, que a manifestação sensível do ser "não significa uma apresentação do todo do Ser ou do Ser como tal, já que ele não seria mais, desde então, ser distante, oculto" (Robert, F. Op. cit., p.268). Porém, por outro lado, afirma que "o aparecer é o próprio ser" ou que "não há ser senão do aparecer" (Ibid., p.343), de modo a opor-se à sua primeira afirmação. Por sua vez, Madison reconhece que, para Merleau-Ponty, "Ser não é aquilo que aparece para a consciência (...), mas é a própria Presença em que a consciência ou o sujeito está presente ao mundo (...). [O] Ser, como fundo de toda aparência e possibilidade de toda aparição, não é ele mesmo o que aparece e é percebido" (Madison, G. B. The Phenomenology of Merleau-Ponty. A search for the limits of consciousness. Ed. supra, p.188).
} 
No primeiro capítulo, vimos que Merleau-Ponty parecia aceitar o seguinte dilema: ou o ser é aquilo que se manifesta para a subjetividade ou o ser é um conjunto de propriedades objetivas completamente estranhas à subjetividade. Na Fenomenologia da Percepção, Merleau-Ponty rejeita explicitamente a segunda alternativa e admite a primeira. Ora, acreditamos que por meio da noção de dimensões transcendentes do ser, o filósofo recusa na verdade esse próprio dilema, pois dispõe de uma armadura teórica que lhe permite reconhecer a independência do ser para além daquilo que é subjetivamente apreendido, sem que tal reconhecimento implique uma defesa do ser em-si objetivo. Os entes ou eventos inobserváveis podem ser considerados, desse novo ponto de vista, como componentes de tais dimensões, os quais só se doam como ausentes (ou seja, indiretamente) e não são positivamente captados pela atividade perceptiva. O passado do mundo, por exemplo, seria expressão de um processo autônomo de organização do ser e não um estado de coisas que só receberia a qualificação de passado por meio da modificação retencional de sua manifestação para uma consciência presente. Pelo contrário, conforme a última ontologia de MerleauPonty, é o tempo presente da consciência que se sustenta pelo passado imemorial do mundo, por uma história ontológica mais ampla que aquela humana. Assim, em seus anos finais, o filósofo não define o ser como aquilo que aparece, tal como fizera na Fenomenologia da Percepção (Cf. PhP, 455), mas insere aquilo que aparece para a subjetividade humana em um campo ontológico que não se esgota no aparecer fenomenal. Daí Merleau-Ponty afirmar, em uma nota inédita, que "o Ser visto como o Ser percebido está eminentemente contido no Ser" ${ }^{\text {68 }}$. Esse Ser, esse campo ontológico que engloba o ser percebido não deve ser concebido como em-si, objetividade positiva, mas como ser sensível que prepara do seu interior a sua manifestação. Mas o sensível não se reduz àquilo que se manifesta, àquilo que dele é apreensível diretamente; o sensível é composto de dimensões que só se apresentam como ausentes, de maneira negativa. Numa outra nota inédita, o filósofo assevera: “o mundo antes de nós, antes da consciência, no qual cremos, é esse além dos limites do campo de nossa vida, é o Ser"69. Esse texto exprime que o modo pelo qual o ser é não se reduz ao que se manifesta

No entanto, Madison também afirma que "o fenômeno humano é um milagre porque nele e através dele tudo o que existe se torna significativo" (Ibid., p.251). Madison também afirma que "o Ser sem o homem não tem sentido, pois o homem (...) é o próprio sentido - logos - do Ser” (Ibid., p.243). Já segundo a nossa interpretação, o fato de que Merleau-Ponty desvela uma sensibilidade inerente ao ser, a qual se prepara do seu interior para a atividade perceptiva humana, não significa reduzir o ser a tal sensibilidade ou assumir que o ser depende das capacidades humanas para possuir alguma estrutura ou sentido.

${ }^{68}$ Nota 10a de novembro de 1959; ver item v do apêndice.

${ }^{69}$ Nota 41a, de setembro de 1959; ver item x do apêndice. 
perceptivelmente; pelo contrário, a manifestação fenomenal é incluída num processo que a excede, mesmo sem ser totalmente estranho a ela. Assim, o ser se caracteriza nos últimos textos de Merleau-Ponty não como um em-si completamente alheio aos conteúdos das vivências perceptivas, e não somente como esse conteúdo, mas como um campo geral de dimensões organizadas autonomamente e entre as quais, como um desvio que as supõe mas que não as abarca, a experiência humana se desenrola.

\section{Uma ontologia metafísica?}

Para finalizar esse trabalho, consideremos um problema já anunciado na introdução, a saber, aquele de avaliar se o projeto ontológico final de Merleau-Ponty, ou seja, se a apresentação de um ser sensível amplo, que inclui dimensões que transcendem a presença ôntica (quer dizer, que transcendem a doação positiva e atual dos entes), é uma empreitada metafísica. É verdade que no curso "A filosofia hoje" Merleau-Ponty apresenta sua investigação como "metafísica no sentido clássico" (NC, 37), já que ela se dedica a explicitar a totalidade do ser e suas articulações internas. Mas ali MerleauPonty simplesmente parece retomar o espírito geral do Grande Racionalismo (século XVII), a saber, tratar da totalidade do real sem confundir o ser com os objetos das ciências, ou as investigações racionais com o conhecimento empírico de relações causais (Cf. S, 186). Não se trata, sem dúvida, de assumir a idéia de um infinito positivo, de um Deus todo poderoso que, criador e ordenador não só do mundo natural mas também das almas, legitimaria a expectativa de que há mais ser que aquele tratado pelas ciências materialistas $^{70}$. Trata-se apenas de reconhecer que os pensadores do século XVII, ao não reduzirem o problema do ser àquele do conhecimento científico, demonstraram uma consciência aguda da amplitude da experiência humana, a mesma que Merleau-Ponty pretende reproduzir em sua própria pesquisa (Cf. S, 191).

A suspeita de que a empreitada filosófica final de Merleau-Ponty é metafísica não vem simplesmente de sua filiação às intenções do Grande Racionalismo, já que, nesse caso, ao menos aparentemente, o filósofo soube separar tais intenções e a realização delas por meio do apelo a um infinito positivo. Tal suspeita é alimentada diretamente por algumas das principais teses da ontologia final de Merleau-Ponty. Michel Haar nos ajuda a explicitar esse tópico. Segundo esse autor, Merleau-Ponty teria universalizado o mundo percebido ou sensível, de maneira a tomá-lo como o próprio

\footnotetext{
${ }^{70}$ Veremos que o apelo a um infinito positivo é justamente o que havia de metafísico no Grande Racionalismo, no sentido que vamos precisar a seguir.
} 
ser. Esse seria um procedimento metafísico: nomear como ser um ente ou uma dimensão ôntica, a qual é então indevidamente hipostasiada. Além disso, a hipóstase metafísica do sensível por Merleau-Ponty teria sido manifestamente insatisfatória, tal como argumenta Haar: "para ser universalizável, mesmo metafisicamente, o mundo percebido não deveria com efeito incluir todas as dimensões? Ora, salta aos olhos que ele não possui nem a História nem a Fala. A universalidade se torna desde então uma abstração metafísica" ${ }^{, 71}$. Haar não se limita, assim, a reconhecer traços metafísicos na ontologia de Merleau-Ponty, mas nota que esses traços pouco convencem, dado seu caráter abstrato, limitado.

A fim de avaliar essas críticas, retomemos a diferença, formulada na introdução, entre ontologia e metafísica. Concebemos a primeira como o estudo dos aspectos mais gerais do ser, ou seja, não como uma análise de algum ente em particular, mas sim do próprio ser pelo qual se afirma que todos os entes são. Já a segunda, seria um certo modo pelo qual a investigação ontológica se realiza. Historicamente a investigação metafísica descreve o ser como algo absolutamente distinto do sensível, o qual seria apenas um efeito secundário de uma realidade supra-sensível, quer dizer, realidade exterior ao mundo manifesto, oposta às aparências e ainda assim causa primeira dessas últimas $^{72}$. Um aspecto particular desse modo metafísico de investigar o ser, tal como acentua Haar, é a hipóstase de algum ente ou aspecto ôntico, o qual então é tomado como ser, como princípio originário que excede todos os entes.

Historicamente a metafísica, no sentido delimitado acima, implicou vários impasses teóricos, de modo que a designação de alguma empreitada filosófica como metafísica significa uma qualificação bastante pejorativa. Entre esses impasses estão aqueles de exceder o domínio da experiência e da verificação de hipóteses no geral, o que reduz o discurso metafísico a um encadeamento lógico de conceitos cuja validade objetiva jamais pode ser atestada. Além disso, a hipóstase injustificada de certas características ônticas implica a incapacidade de apreender a complexidade do real, já que se favorece somente alguns de seus aspectos, tomados então apressadamente como cânones para se compreender todos os demais. Vale notar aqui que, desde cedo, Merleau-Ponty se preocupou, ao assumir uma inspiração "metafísica", em afastar-se desses impasses. Segundo a Fenomenologia da Percepção, se a metafísica for

\footnotetext{
${ }^{71}$ Haar, M. art. cit., p.33.

72 Daí que o apelo a um infinito positivo seja marca de uma investigação metafísica, conforme anunciamos na nota 70 .
} 
concebida como "emergência de um além da natureza" (PhP, 195), então deve-se reconhecer que ela está "em todo lugar" (Ibid.), quer dizer, que ela não implica a postulação de um reino supra-sensível, mas sim a reconsideração da amplitude do próprio mundo sensível. No artigo "O metafísico no homem", de 1947, Merleau-Ponty explicita essa amplitude da metafísica: os outros, a história, a cultura, o mundo em geral; todos esses temas seriam metafísicos (Cf. $\mathrm{SnS}, 115)$. Afinal, a experiência do mundo, em suas diversas camadas (sensível, histórica, cultural, etc.), sempre extrapola a estrita investigação causal-materialista das ciências da natureza. Sempre há aspectos da experiência irredutíveis aos esquemas heurísticos reducionistas, mas que nem por isso são parte de um reino inacessível ao conhecimento humano. Quer dizer que a metafísica, no sentido assumido por Merleau-Ponty, não é índice de um domínio suprasensível, mas de um tipo de consciência, de um modo particular de investigar os fatos cotidianos, que não os reduz a objetos compreensíveis somente pelo aparato técnicomatemático, mas que neles observa processos expressivos, latências fenomenais, etc. ${ }^{73}$.

Nós reconhecemos, conforme as citações acima, que Merleau-Ponty jamais pretendeu se filiar à metafísica no sentido pejorativo. Mas nos interessa aqui questionar se sua ontologia é metafísica, ou seja, se aqueles impasses mencionados no parágrafo anterior podem ser atribuídos ao seu projeto final. De maneira geral, parece que não. Como vimos no decorrer dessa tese, o filósofo não defende a hipótese de um ser suprasensível, o qual seria causa primeira das aparências sensíveis. Trata-se somente de conceber um ser sensível amplo, que não rejeita a ocultação, a profundidade invisível. Não se defende haver uma camada subjacente e exterior aos entes, e sim um excesso dimensional inerente àquilo mesmo que se manifesta. A invisibilidade, em relação à qual os entes visíveis estão centrados ou ordenados (Cf. VI, 278, jan. 1960), não é um substrato independente dos entes, mas seu outro lado, seu inverso (Cf. VI, 303, maio 1960), ou seja, uma latência que entrecorta os próprios entes e que, assim, não é um princípio autônomo deles separado. O ser dimensional que Merleau-Ponty tenta descrever só se deixa entrever por meio dos entes e está longe da descrição metafísica do supra-sensível.

No que concerne à suspeita particular de Haar (de que Merleau-Ponty teria hipostasiado um aspecto ôntico), cabe uma análise mais detalhada. Como já expusemos

\footnotetext{
73 “A metafísica não é uma construção de conceitos pelos quais nós tentaríamos tornar menos sensíveis nossos paradoxos; é a experiência que nós dele fazemos em todas as situações da história pessoal e coletiva - e das ações que, assumindo-os, os transformam em razão" (SnS, 117).
} 
no capítulo anterior, Merleau-Ponty realmente toma o ser sensível como universal, quer dizer, como campo ontológico que envolve todas as dimensões do mundo (inclusive aqueles da história e da fala, conforme Haar havia suspeitado) (Cf. S, 217). A perspectiva de investigar o ser sensível em seu caráter bruto (quer dizer, independentemente das idealizações antropológicas projetadas sobre ele) almeja explicitar um campo anterior às cisões entre sujeito e objeto, atividade e passividade, cultura e natureza. No início dos anos cinqüenta, Merleau-Ponty apontava para a expressão como operador capaz de realizar a superação de tais dicotomias ${ }^{74}$. Embora a expressão jamais saia completamente de cena e continue a exercer importantes papéis na obra do filósofo (tal como aquele de explicitar a função criadora da arte e da linguagem), deve-se notar que no final dos anos cinqüenta, o ser sensível universal é apresentado como matriz da própria expressão, e, por conseguinte, como responsável último pela superação de tais cisões ${ }^{75}$. Essa gênese da expressão no ser é clara em relação à linguagem, já que, segundo Merleau-Ponty, o ser bruto contém tudo o que poderá ser dito e antecipa a produção criativa da língua ${ }^{76}$ (embora não dispense essa última, pois depende dela para se manifestar, cf. cap. IV). Além disso, mesmo a expressividade perceptiva, quer dizer, a remissão espontânea dos fenômenos dados àqueles visados, decorre de uma profundidade inerente ao mundo, a qual é condição da organização das coisas em horizontes inesgotáveis (cf. VI, 268, nov. 1959; cf. cap. IV). Como se vê, em seus anos finais, Merleau-Ponty de fato apresenta o ser sensível como dimensão ou campo geral capaz de reintegrar algumas das cisões mais agudas da tradição filosófica. Não há certamente apelo a um infinito positivo, a um ser suprasensível que guardaria a inteligibilidade das aparências fenomenais para além do seu caráter objetivo, mas há a confiança em que um infinito negativo, quer dizer, um ser

\footnotetext{
74 'Há no fenômeno da expressão uma 'boa ambigüidade', quer dizer, uma espontaneidade que realiza o que parecia impossível, ao se considerar os elementos separados, que reúne em um só tecido a pluralidade das mônadas, o passado e o presente, a natureza e a cultura" (PII, 48).

${ }^{75}$ De certo modo já havia essa perspectiva mesmo no início dos anos cinqüenta. No texto "Titres et Travaux", de 1951, Merleau-Ponty exalta a investigação filosófica que se serve dos dados científicos e afirma: "talvez essas pesquisas convergentes acabarão por evidenciar um meio comum da filosofia e do saber positivo, e por nos revelar, aquém do sujeito e do objeto puro, como uma terceira dimensão em que nossa atividade e nossa passividade, nossa autonomia e nossa dependência, cessariam de ser contraditórias" (PII, 13). Aqui Merleau-Ponty parece apontar para uma camada de ser anterior às antinomias clássicas.

76 "O mundo perceptivo 'amorfo' (...) é no fundo o Ser no sentido de Heidegger (...), que aparece como contendo tudo o que será alguma vez dito" (VI, 221, jan. 1959). Em outra passagem, Merleau-Ponty afirma: "se se explicitasse completamente a arquitetônica do corpo humano, sua armadura ontológica e como ele se vê e se ouve, veríamos que a estrutura de seu mundo mudo é tal que todas as possibilidades da linguagem aí estão dadas" (VI, 200).
} 
sensível ampliado, que envolve latências dimensionais inesgotáveis, poderia resolver praticamente todos os problemas filosóficos.

Ante esse infinito negativo, que se encontraria como latência nos próprios fatos, Merleau-Ponty afirma: "eu sou contra a finitude no sentido empírico, existência de fato que tem limites, e é por isso que eu sou pela metafísica" (VI, 300, maio 1960). Nessa afirmação, já não é tão claro se Merleau-Ponty distingue entre um sentido positivo de metafísica e aquele sentido pejorativo, do qual ele sempre procurou se afastar. Afinal, quanto a esse último, o filósofo se impressionava com a maneira inocente, ingênua pela qual os grandes racionalistas recorriam ao infinito positivo e, desse modo, acabavam por se identificar a tal sentido pejorativo (S, 189). No entanto, talvez Merleau-Ponty tenha reproduzido um artifício semelhante ao atribuir tantos prodígios às latências inesgotáveis do ser sensível. Concebido tal qual infinito negativo, o ser é apresentado como o que prepara em si próprio sua manifestação subjetiva (cf. cap. III), como o que contém antecipadamente a expressão lingüística e como dimensão oculta que resolve as cisões substanciais clássicas e permite reconfigurar os conceitos filosóficos (cf. NC, 37, 39; VI, 219, jan. 1959).

É legitimo atribuir todas essas realizações ao ser sensível? Haar julgava tal atribuição uma hipóstase metafísica, a qual, ainda mais, seria imperfeita ou abstrata, pois o sensível não poderia incluir as dimensões da história e da fala. De nossa parte, julgamos que a tentativa de ampliar o conceito de sensível era uma via pela qual Merleau-Ponty antecipadamente se precavia contra tal objeção. O sensível não deve ser compreendido como campo de assimilação fenomenal positiva, mas como conjunto de dimensões que se apresentam de maneira originária, ainda que como ausentes ${ }^{77}$. Não haveria, assim, universalização indevida de um aspecto ôntico (aquele da apreensão de dados sensoriais $^{78}$ ), mas tentativa de caracterizar o ser como latências inesgotáveis que se fazem pressentir como excesso por meio dos entes (Cf. VI, 298, maio 1960). O projeto de Merleau-Ponty de buscar as dimensões invisíveis da história e da cultura (tal

\footnotetext{
${ }^{77}$ Daí que a doação do mundo para a fé perceptiva seja estudada, nos textos finais de Merleau-Ponty, não como mera atividade sensorial, mas como "arquétipo do encontro originário, imitado e renovado no encontro do passado, do imaginário, da idéia" (VI, 208). Essa doação originária, pela qual o sensível é caracterizado e de que a percepção é só o modelo, não exclui a exposição de ausências irremediáveis, as quais, como vimos, são desveladas indiretamente (por apelo aos resultados das ciências e artes). Nesse sentido, Merleau-Ponty afirma: "o sensível é precisamente esse meio em que pode existir o ser sem que ele tenha de ser posto" (VI, 263, out. 1959).

${ }^{78}$ Haar compreende de maneira excessivamente redutora "o campo 'universal' do Sensível" como o que "se doa à percepção" (Haar, M. art. cit., p.10), e não leva em conta que esse doar-se pode envolver dimensões inevitavelmente ausentes.
} 
como expusemos neste capítulo) explicita a preocupação de não realizar nenhuma hipóstase indevida, que só abstratamente envolveria a totalidade do real. Tratar-se-ia, antes, de ampliar a análise do ser dimensional justamente para os domínios cobrados por Haar. Lembremos que ao menos no que se refere à fala, Merleau-Ponty esboça essa ampliação ao considerar os lekta e o pensamento em geral como um tipo de dimensão invisível (Cf. VI, VI, 305, maio 1960). Numa nota inédita, o filósofo sustenta que “deve-se considerar a fala como articulada sobre matrizes simbólicas, exatamente da mesma forma que a percepção. Matrizes simbólicas que não são conceitos, mas pivôs ou charneiras, sistemas tácitos de equivalência" ${ }^{\text {79 }}$. Haveria, dessa maneira, matrizes invisíveis que envolvem a própria fala e da qual ela deriva (assim como os entes percebidos se ordenam em relação a dimensões transcendentes) ${ }^{80}$.

Esse tema da linguagem nos leva a afirmar que embora o estado de inacabamento da ontologia final de Merleau-Ponty faculte a crítica de abordagem metafísica, deve-se ao menos conceder que o filósofo se preocupava em evitar tal resultado. Porém, é inegável que os textos legados por Merleau-Ponty como sua última ontologia somente apontam para certas soluções, as quais efetivamente não se cumpriram $^{81}$. Os textos finais do filósofo não apresentam uma argumentação desenvolvida de maneira suficiente para afastar definitivamente os problemas ali reconhecíveis. Não é claro, por exemplo, como se poderia formular uma abordagem da história em termos de ser dimensional. Também não é claro, conforme vimos no capítulo anterior, como o corpo excede sua comunidade sensível com a carne do mundo e se torna corpo senciente. Quanto a esse tópico, parece que Merleau-Ponty, ao acentuar vigorosamente os aspectos passivos que fundam as atividades subjetivas (por exemplo, a sensibilidade inerente ao ser como condição da percepção) ${ }^{82}$, acaba por descrever tais atividades de maneira insuficiente ${ }^{83}$. Esses exemplos mostram que a ontologia final de

\footnotetext{
${ }^{79}$ Nota 31a, setembro 1959, ver item $\mathrm{z}$ do apêndice.

${ }^{80}$ Conforme Merleau-Ponty afirma em uma nota publicada: "o sentido invisível é a membrana da palavra" (VI, 273, dez. 1959).

${ }^{81}$ Mesmo no caso da análise da linguagem, o próprio Merleau-Ponty reconhece que a remissão da significatividade lingüística a matrizes invisíveis de sentido não esclarece como as "idéias da inteligência" surgem sobre tal idealidade sensível (Cf. VI, 197-8).

82 “A filosofia jamais falou (...) da passividade de nossa atividade (...): por mais novas que sejam nossas iniciativas, elas nascem no coração do ser, elas estão engrenadas no tempo que jorra em nós” (VI, 270, nov. 1959).

83 “O espírito não está nem aqui, nem aqui, nem aqui... (...) O espírito não está em nenhum lugar objetivo e no entanto ele se investe em um local em que chega por suas bordas [entours]" (VI, 271, nov. 1959). É questionável se essa abordagem puramente negativa da atividade subjetiva (a qual não é isso nem aquilo, não se encontra em nenhum lugar, etc.) basta para circunscrever a atividade de nossa passividade, quer dizer, o outro lado do problema geral a que Merleau-Ponty tanto se dedicou em seus anos finais ao
} 
Merleau-Ponty, embora anule alguns dos problemas contidos em sua ontologia fenomenológica dos anos quarenta (tais como aquele das conseqüências idealistas), instaura novas dificuldades, para as quais a morte repentina do filósofo impediu que alguma resposta articulada fosse oferecida.

descentrar a subjetividade e atribuir uma intencionalidade originária ao próprio ser (Cf. VI, 293, abril 1960). 


\section{Apêndice - Notas inéditas de Merleau-Ponty}

A fim de tornar acessíveis as notas inéditas de Merleau-Ponty citadas em nosso texto, reproduzimo-las a seguir exatamente conforme a transcrição de Renaud Barbaras. As palavras entre colchetes indicam termos de leitura duvidosa ou anotações de Merleau-Ponty à margem do texto principal.

a) Nota 50, sem data, agrupada ao esboço do plano e da redação de Être et Monde:

[...] Notre corporéité: ne pas la mettre au centre comme j'ai fait dans Phénoménologie de la Perception : en un sens, elle n'est que la charnière du monde, sa pesanteur n'est que celle du monde. Elle n'est que puissance d'un [léger] écart par rapport au monde. Le fait que, par notre mort, notre monde disparaît, permet seulement de dire que notre corps est cause de notre monde [...].

b) Texto datilografado n.13 (Mercredi 7 octobre [1958 ?]):

Transformer mon: esse est percipi

en écartant toute équivoque psychologiste: il ne s'agit pas d'anthropologie, il s'agit de l'Être brut ou sauvage.

Il s'agit de rendre sensible l'Être non-substantiel, non-objectif, le Rose Sein (Heidegger), l'Être qui n'a pas besoin de synopsis (cf. Sartre: il n'y a que de l'être. Mais il prend dans cette phrase l'être comme identique. Il reste actualiste).

Créatures, homme, Dieu, - confusion de notre pensée moderne à l'égard des trois philosophies possibles, cette confusion liée à notre ignorance de l'Être.

Esquisse de l'ontologie interrogative qui l'expliquerait et la dépasserait. Sartre et Heidegger. Mais cette ontologie à faire, nous ne pouvons la faire que moyennant critique point par point du complexe cartésien (critique de l'Ens necessitarium et de la pensée négativiste-positiviste) (et de toutes ses conséquences). [en marge: voir Delhomme : La Pensée interrogative].

Voilà le plan prévu.

Mais peut-être faut-il commencer directement par une position de l'ontologie interrogative i.e. par une description de l'être au présent, fondée sur une élimination de l'ontique, de la causa sui, de l'ens necessarium. 
Peut-être aussi : partir de résultats de la Phénoménologie de la Perception et montrer qu'il faut les transformer en ontologie 1 / Passer de l'affirmation du « perçu » à celle de l'être brut

2 / Passer de l'idée du corps comme sujet à celle de

l'être indivis.

Poser l'ontologie interrogative comme vision de la membrure nature-homme-être.

Dire que la conception de la philosophie qui est ici présentée dépend de ce qui sera dit plus loin sur le langage, - et ne le commande pas seulement. De même cette ontologie dépend de ce qui sera dit sur les choses, sur la vie, sur la phusis, et ne le commande pas seulement. Circularité.

c) Nota 12b, 27 de outubro de 1958 :

Dans mon introduction à l'ontologie

Reprendre les résultats de la Phénoménologie de la Perception et montrer dans quel sens il faut les interpréter pour aller au-delà par ex. [...] en quel sens l'homme est premier.

en quel sens cependant l'être est, non du perçu, mais ce en vue de quoi est la perception [...].

Rappeler une définition de la vérité comme ambiguïté antéprédicative (et la conception de l'imaginaire comme mythe qui est par là même rendue possible) et cela par opposition à la définition de la vérité comme Richtigkeit.

d) Nota 12 de um grupo de vinte e duas notas de 1958-9:

La vie [de l'emblystome] n'est pas une force cachée sous les détails observables, « derrière » les apparences : dessous, derrière, on ne trouve jamais que d'autres détails. La réalité et la totalité sont dans l'apparence, le devenir, la cristallisation que l'on voit. Non certes dans l'apparence divisée par une attitude analytique, mais dans l'apparence avant cette division. Cela est vrai de la multiplicité spatiale et de la multiplicité temporelle d'une vie : elle est le champ qui n'a pas à se recréer à chaque instant ex nihilo, et qui n'a pas de permanence substantielle, qui n'est à l'abri d'aucun accident, qui persévère dans l'être si seulement ... rien ne vient l'interrompre.

[...]

Tout cela ne veut-il pas dire quelque chose comme ce que Ruyer dit (mal) ? A savoir: la vie n'est visible et n'est qu'à une certaine échelle d'observation, 
macroscopique, - mais à cette échelle, entièrement vraie et originale. Elle est solidaire donc d'une vision. Elle n'est pas en soi, comme le corpuscule insécable. Elle est par la cohésion avec soi de la forme vraie...

Soit. Mais ce n'est pas dire qu'elle est pour soi, qu'elle est conscience, même non sensorielle (qu'est-ce qu'une conscience non-sensorielle ?). Il faut donner un nom et un statut à ce «lieu» où se rassemble une vie. Ce n'est ni notre conscience, ni une conscience. La notion d'échelle n'implique pas celle de sujets observateurs au sens de « consciences», mais seulement celle de perspectives dessinées par un poste d'observation, définies par un poste d'où... se fera la vision. Poussé à bout, la réduction du monde à une suite de perspectives et d'échelles perd tout caractère subjectiviste. Elle implique qu'on remanie l'idée du monde en une somme d'étants survolés. Elle n'est pas anthropologique, ni anthropomorphique en ce sens qu'elle incorpore au contraire l'homme à la définition du monde, fait paraître l'homme comme un ingrédient du monde, morceau du monde qui se replie sur lui-même - l'homme pré-humaniste, l'homme brut, l'homme [fondateur]. Elle veut dire seulement que la totalité n'est pas moins réelle que les parties.

e) Nota 40b, 28 de setembro de 1955 :

Reprendre la question de la cosmogonie du monde perçu.

J'admets que le corps est conditionnant par rapport au spectacle perçu, que l'installation de ce spectacle se fait grâce à l'apparition, dans le monde perçu, de cet appareil à vivre qu'on appelle mon corps vivant. J'admets dans cette mesure l'antériorité de l'en-soi sur le pour-soi. Mais, par ailleurs, cet en-soi, je me refuse à le concevoir comme le fait le réalisme des savants, je dis que dans sa texture même, il renvoie à mon (un) centre de perspective, qui est à concevoir en termes de spectacle perçu.

J'admets donc une dialectique, un double point de vue. Mais que signifie cette dualité, à moins que ce ne soit passage d'un des points de vue dans l'autre ? Et que signifie passage ? Car il ne faut pas que ce soit «enveloppement». Il faut que ce soit contact à distance, contact indirect, obtenu justement parce qu'il n'est pas chosifié, et qui, sous le regard de la réflexion, devient l'impossible.

Surgissement dans mon champ d'un au-delà de mon champ (mes prédécesseurs, mes consorts), - non pas seulement l'X qui m'objective ou me [...], mais un alter ego qui est « de mon côté », comme on dit qu'un enfant est « du côté » de son père [avec qui 
j'entretiens un rapport (d'ailleurs réversible) de générativité (et si je suis son père, il est mon père - ubiquité de la situation, totalité à l'intérieur de la partialité) ].

La «nature »n'est pas seulement en-soi d'où nous nous ..., mais elle comporte cette couche de socialité : ce milieu «général d des consorts, leur apparition comme rameaux d'une même souche.

Et cependant, ce qui est rendu possible par ces [préparations] «naturelles » les rejette à distance, au passé, ou dépassé quand il passe à l'actuel. Suscitation d'une liberté par une liberté, l'une est entée sur l'autre comme un corps sur un corps. Et nous sommes entés sur l'animalité, et l'animalité sur la nature. L'homme ne peut pas devenir homme, sinon en présence d'un adulte (les enfants « sauvages »). Ceci est l'attestation de l'irréalité de l'individu.

Réellement, un enfant n'est rien si ne s'offre à lui cet instrument, dont il apprend à jouer, avec lequel il apprend à devenir homme, et qui est un alter ego. Projection et introjection, non « conscience ».

Et cependant, tout ceci est pour lui appel à être soi, individu de classe. La généralité «naturelle» est donc conservée et transformée. La culture est, dans son contenu, tout autre que la nature, et cependant elle est enracinée dans la Fortpflanzung, la Fortpflanzung apparaît comme une préparation du rapport alter ego, comme faite pour lui et lui, fait pour elle.

Donc on ne rattache pas le pour-soi à un en-soi comme à une condition par rapport à laquelle il serait ultérieur. Le corps lui-même ne peut être perçu qu'intérieur au champ phénoménal. Mais pas davantage il ne faut enfermer le corps et le monde « réel » qui traîne après lui dans « ma représentation ». Car celle-ci se donne à moimême comme [continuant] une histoire et une nature, qui ne sont pas pour... la suite. [Inutile] d'espérer enfermer tout ce déploiement extérieur dans un absolu qui soi sujet: comme il ne serait pas le sujet au sens où nous le sommes, il serait pour nous objet pur. N'étant pas né comme nous, fils de la terre, il ne serait pas un toi pour nous : il n'y a de toi que celui qui peut me répondre, à qui je suis aussi nécessaire qu'il m'est nécessaire.

Ce qu'il y a, c'est donc des perspectives dont chacune s'éprouve comme différente par rapport aux autres, manque des autres et les éprouve comme différences par rapport à soi $(=X)$ - dont chacune sont les [parois épaisses] parce qu'elles sont tous les autres sédimentés : mon corps est les autres corps, ma «psyché » les autres psychés, moi comme sujet transcendantal n'importe quel autre... et cela non en vertu d'une universalité solipsiste, mais parce que je pose le pied là où quelque chose est prêt à le 
recevoir, j'enjambe les « conditions », je les implique dans mon geste, chacun de mes gestes prend l'inconnu pour connu.

f) Nota 1a, dezembro de 1959 :

Catalogue de Giorgio de [Gisgi?]. [20 lignes de citations].

Cette idée des «éléments », - non seulement des éléments de la nature, mais des éléments de notre vie : la sculpture 58-59 est l'élément route de Carpentras à Aix avec maman: lignes solennelles bordées d'ombres verticales comme des cyprès ou horizontales comme les plans du Lubéron - cette idée à appliquer à analyse nouvelle de la subjectivité : erreur immense de la considérer comme flux des Erlebnisse. Elle est avant tout champ, et même sa temporalité a cette structure. Absurdité de la concevoir comme un présent ponctuel et la série indéfinie des Erlebnisse ponctuels-individuels qui seraient le passé. Par exemple, ces sculptures me rappellent de beaux minerais, - un jour où quelqu'un me montrait, avec une sorte de ferveur qui me surprenait, des minerais, et m'en donnait quelques uns, non sans hésitation. Je n'arrive pas à préciser le souvenir ni le lieu et reste dans le doute : il me semble (mais plutôt par raisonnement, que c'était au Congo belge, à E...-ville. Ce ne peut être que là. Mais qui ? Je sais seulement que c'était une femme). Or ce «souvenir » n'est pas un Erlebnis individuel rejoint par rétention de rétention dans sa singularité. Ni par «association ». Il est :

$1 /$ une catégorie, un existential [lié], il est vraiment déposé dans cette sculpture que je vois, comme est déposé dans les trois arbres de Martinville un certain appel.

2 / un élément donc au sens de l'eau, de l'air etc. c'est-à-dire non pas un objet, ni un individu mais un mode de sentir. Le souvenir comme référence à un Zeitpunkt est à comprendre comme cas limite de ces matrices. Il n'y a pas de Zeitpunkt, pas plus que de point spatial. Il n'y a que des taches, temporelles comme spatiales, i.e. des êtres de transcendance. Et celui qui comprend ces êtres de transcendance est champ et non pas du tout « représentation ».

g) Nota 19 de um grupo de vinte e duas notas de 1958-9:

L'Être sensible ou brut

Montrer que cela ne veut rien dire: les choses sensibles n'existent pas. Ce qui existe, ce sont les objets construits par la physique.

En réalité : dans la mesure où ils peuvent être dits existants, c'est qu'ils sont directement ou indirectement perceptibles ou sensibles. 
A ce titre ils sont bien réels ou des traits du réel

Mais aucun d'eux n'offre la Selbstgegebenheit.

Ils ne sont réels que comme prédicats ou [...] des choses sensibles.

L'être sensible comme transcendance.

C'est lui qui stiftet tout être. Il n'y a pas à choisir entre lui et l'objet de science d'ailleurs. Car l'être sensible ne se confond nullement avec ce qu'il y a [«d'énoncé »] dans les qualités sensibles. Et, dans sa structure de champ, il est précisément homogène à l'objet de science au sens moderne.

Possibilité, d'ailleurs, d'une mathématisation éventuelle aussi bien des sciences sociales que de psychologie. Ce qui est certain seulement, c'est qu'elle ne nous donnera pas l'être du social, l'être du monde, la philosophie.

Aucune rivalité, de même, entre mathématisme en biologie et biologie descriptive.

Le monde de la philosophie, c'est le monde dans son relief, le monde brut et le monde élaboré dans la perspective du monde brut, c'est le monde de l'homme vivant et non pas le monde plat des objets.

h) Nota 4 de um grupo de vinte e duas notas de 1958-9:

Valeur du dualisme - ou plutôt refus d'un monisme explicatif qui aurait recours à ontologie « intermédiaire ».

Je cherche un milieu ontologique, le champ qui réunisse l'objet et la conscience. Et il le faut bien, si l'on veut sortir de la philosophie idéaliste.

Mais le champ, l'être brut, (celui de la nature inanimée, celui de l'organisme) ne doit pas être conçu comme une étoffe dans laquelle seraient taillés et l'objet et la conscience, et l'ordre de la causalité et celui du sens. (En marge : donc il faut éclairement radical du rapport esse - percipi).

C'est une fiction d'imaginer entre le vécu et le corps objectif tout un grouillement dans la nuit [d'êtres] de raison qui seraient des champs superposés et faisant la liaison du monde de la causalité et du vécu.

Ma vision de l'être brut doit être le refus d'un tel «intermédiaire ». C'est l'idée d'une philosophie comme usage préobjectif du concept, d'une philosophie comme remise en présence de la magie naturelle où l'objectif et le subjectif sont indivis et communiquent par leur lien paradoxal, c'est l'idée d'une philosophie comme autre intelligibilité que l'intelligibilité d'entendement. 
i) Nota 36a, agosto de 1959 :

Sur Sarte (11 lignes).

[...] Perception. Configuration.

Il y a le possible de réflexion, celui qu'on définit comme attribut de la conscience « représentation », « projet», « ek-stase ». Et il y a le possible brut ou sauvage, celui des contours, des «configurations », celui des choses «cachées » par d'autres, celui de l'effet tunnel, la masse de l'être qui fait que l'être n'est pas être-perçu [...]. Être de latence, préobjectif.

Possible vertical, moment du monde vertical. L'autre est possible perceptif, celui de la «possibilité permanente de sensation»sans Vorhabe, qui n'est rien d'autre que : si je pensais le mouvement, cette expérience serait donnée, donnée dans le sens d'en-soi.

j) Nota 26b, 1958 :

L'esprit ou la conscience déborde le corps phénoménal émergeant (émergent) dans l'invisible. Il y a là un certain dualisme, incontestable.

Mais ce dualisme ne signifie pas deux substances: il signifie seulement un certain porte-à-faux de la signification pointant hors la masse du visible. Il signifie un certain écart par rapport à un niveau où âme et corps se recouvrent.

De même ce [dernier ?] niveau ne signifie pas monisme. Il signifie seulement que l'esprit prend son élan dans l'ordre de la couche du sentir et de la nature.

Le corps, l'esprit n'est « ni premier ni second». Ceci à la fois contre monisme et contre dualisme.

Mais il faut aussi rejeter la conception dialectique [nouvelle], qui n'est rien d'autre que la bêtise d'un esprit [superstructure formant] l'existence. Bêtise d'idées telles que : le corps, c'est l'esprit en soi, ou l'esprit, c'est le corps pour soi. Bêtise de l’hégélianisme.

l) Nota 92a, 11 de janeiro de 1959 :

1/ Non pas une philosophie du pour soi et du pour autrui, mais une philosophie du Füreinander.

2/ Autrui est l'être non Urpräsentierbar, qui n'est pas susceptible d'être donné luimême, sans médium interposé, mais cela il l'est absolument : il est donné lui-même comme ce qui n'est pas originairement donnable. 
3/ La corporéité se déduit de la pluralité des sujets : dès qu'ils sont plusieurs, ils sont donnés l'un à l'autre $d u$ dehors, i.e. donnés comme non-donné - présence d'une absence - manques - négativités qui ne sont pas pour moi seulement.

m) Nota 7, fevereiro de 1960 :

Le langage - l'appareil qui engendre pour nous des perceptions de l'invisible.

Les perceptions du visible sont déjà perceptions de l'invisible: la couleur devenant invisible quand elle passe en niveau.

L'esprit, le concept, le spirituel ne sont rien que cette structure remaniée, reconstruite par le langage.

Et, au delà du langage, par le milieu dans lequel il fait signe et qui est aux idées ce que le monde sensible est aux choses : l'Être.

n) Nota 24b, 1958 :

La guerre, l'histoire, le social, les êtres culturels, comme êtres invisibles. C'està-dire non pas comme significations - mais comme... ces arceaux qui unissent dans l'invisible, les visions [?] que nous voyons, ce vers quoi font signe les traces sensibles d'un passage de l'événement.

les pivots, les matrices symboliques sont de cet ordre.

Ce non-être sur lequel s'appuie tout l'être de notre vie historique mais : [bêtise de l'idée de... en face de cela] ? [+ 7 lignes]

o) Nota $54 a$, maio de 1959 :

Sur l'ouverture -> Fin:

Tout dépend de la saisie du «noyau d'être » dont parle Sartre. Tout dépend de la possibilité de concevoir une intuition qui ne soit pas coïncidence avec l'Être, mais vraiment ouverture, qui donne un sens ouvert et non pas un sens clos, i.e. une intuition, non pas négativiste positiviste, mais vraiment Offenheit. [...].

La subjectivité est temps - mais tout temps n'est pas de subjectivité - le temps comme ontogenèse.

p) Nota 2b, 1958 :

Le problème: les structures du temps (cyclique etc.) que révèle l'ethnologie sont-elles des modalités empiriques, des contenus, des objets - ou bien sont-elles des 
temporalités, bien que la réflexion montre que le temps est unique, comme condition a priori d'un monde. Ce problème ne comporte pas de solution dans les termes où il est posé là.

Il n'en comporte que si l'on revient du temps schématisé en objet ou représentation (forme de l'intuition et intuition formelle) à un temps préobjectif et présubjectif, dont la perception est imperception - il faut qu'ici l' « objet » soit, non pas positif, mais négation de la négation, que la présence soit non-absence, bref que le temps soit lui aussi mis au nombre des transcendants, être à distance qui ne comporte ni proximité absolue, ni coïncidence, ni même cette forme subtile de coïncidence qu'est le « déploiement». Le temps est ce par rapport à quoi certaines équivalences perceptives fonctionnent, ou certaines différences, certains écarts. Le temps qui n'est ni nous ni hors di nous, ni objet ni sujet, mais la membrure même du champ, l'axe autour duquel il est monté - exclut la question de savoir comment il en vient à être pour nous, à être perçu. Il est dimension d'un champ par lui même amorphe, distribution de valeurs ou de significations. Comme tous les autres perçus, il se forme, non pas devant nous, mais entre nous et les « choses ».

Dans ce temps là, ni sériel ni cyclique, qui n'est pas fait de maintenant mais que est tout apparence, apparence irrécusable, qui n'est jamais contemplé mais toujours entre nos actes de contemplation, toujours marginal, on peut dire sans contradiction qu'il est commun à tous les hommes et qu'il n'empêche pas les structurations les plus opposés, précisément parce que son mode d'être n'est pas l'être-objet, la signification, mais l'écart entre significations.

L'idée de l'être-à-distance exige corrélativement une idée de la noesis comme [constellation] [fourmillante] de chemins possibles, d'itinéraires esquissés (la «sensation» est au bout de ces chemins). L'idée de la perception comme nonimperception exige aussi un remaniement complet de toutes nos notions du sujet : s'il n'y a pas thèse il n'y a pas acte, s'il n'y a pas acte, il y a écart par rapport à une perception globale du monde qui elle-même n'est pas un acte.

q) Nota $4 b, 1958$ :

Retour à l'Être brut - [ ] : des variétés empiriques ne peuvent rien prouver contre notre a priori.

Revenir au temps, à l'espace bruts, sauvages, antépredicatifs, «amorphes » comme à la matrice d'où dérivent les temps cycliques, sériels, etc. On dit : les temps 
cycliques par ex. ne sont pas d'autres temps, ce sont des contenus, contenus qui, devant la réflexion, impliquent le temps sériel comme leur condition a priori, ainsi que [l'indique ?] Kant, puisque ce temps est [ ] ce par quoi est possible la [.....keit]. Mais cette référence au temps occidental-cartésien comme terme d'une alternative dont l'autre est néant de pensée et d'être, c'est précisément l'illusion des illusions. La distinction de forme et contenu, la promotion du temps sériel au rang de forme universelle de la [.....keit] - corrélativement la dégradation des autres temps au rang de « contenus empiriques » (à «la limite impensables ») c'est précisément ce qui est en question.

\section{$[\ldots]$}

=> Car le philosophe avec son algèbre de l'être et du néant vise le monde même et le logos même dont la philosophie est dans le meilleur des cas un équivalent formel et [ultérieur].

r) Nota 51 (16. VI. 1959) :

Les psychologues montrent que notre appareil perceptif traduit quelquefois en relations temporelles des relations spatiales (mouvement stroboscopique). Cela veut dire qu'il est comme un langage dans lequel certaines équivalences permettent des « opérations » formelles ou aveugles. Il semble en résulter qu'il n'y a pas d'expérience de l'espace ou du temps, que les espaces et les temps sont toujours des significations attribuées.

Cependant, il n'y a pas à choisir entre une conception de l'espace et du temps comme systèmes, langages, et une conception intuitive. Qu'il y ait des illusions fondées sur les connexions du système ne prouve pas qu'il n'y ait pas d'expérience. Car la distribution des temps et des espaces est elle-même un phénomène de champ, - tout ce qu'elle prouve, c'est qu'il y a, au-delà du champ temporel ou spatial, un champ universel, c'est que l'expérience du temps et de l'espace «Selbst» n'est jamais isolée, qu'elle est centrée [sur/dans/par] une expérience de l'être où temps et espace s'échangent selon une syntaxe étrange. Mais cette expérience de l'être indivis, système de systèmes, chose des choses, est intuition. Et celle de l'espace et du temps « attribuées » à des [traits] qui la distinguent de l'espace et du temps vraiment vécus. (Pourtant j'ai admis dans Phénoménologie de la Perception l'ambivalence de l'imaginaire et du réel). 
Temps et espace sont lambeaux de l'expérience intégrale qui est l'expérience du « Il y a » d'espace-temps. Le mouvement stroboscopique : réapparition du « Il y a » (le « quelque chose qui se meut») entre les «positions» qui deviennent sa «trace »: la « syntaxe » de l'appareil perceptif n'est que sous-produit du « Il y a » de transcendance.

Problème classique : Il y a une conscience de l'espace et cette conscience de l'espace est à son tour saisie comme laissant un sillage temporel tracé par le je transcendantal dans le moi empirique.

En partant de la présence d'espace-temps, en faisant de la spatialité un moment du temps ou de la temporalité un ingrédient indispensable de l'espace, je défais la dualité : expérience externe - forme du sens intime : il y a un espace du sens intime, et il y a tissu temporel de l'expérience externe. Le temps cesse d'être une « série ». L'espace n'est plus simultanéité que de simple vue, par transcendance.

A l'égard de la présence d'espace-temps, l'analyse réflexive n'est plus possible, qui fondait espace et temps sur un tracé actif, et le lié sur la conscience de liaison. Car les liens intérieurs à l'espace et ceux qui soutiennent le temps sont désormais indiscernables : le Dasein est «spatial» et le monde est «subjectif». Ce qui était construction ordonnée devient Ineinander, unité d'indivision. Corrélativement, il n'y a plus conscience de ... l'espace et conscience du ... temps : comme Husserl l'indique, le passé proche, le passé originaire, n'est pas intentionnalité (pas plus que la «synthèse » de champ spatial). C'est déhiscence. En disant que le temps est Selbsterscheinung, Husserl ne dit pas qu'il est «conscience», mais que la «conscience » est flux. Je continue en disant que l'espace est Selbsterscheinung. La zone de Selbsterscheinung le champ de la présence espace-temps - est conçue elle-même comme arrachement et non synopsis, écart par rapport au ici-maintenant, Ineinander des Espaces et des Temps. Il n'y a rien d'autre que cela en moi : le temps serial, l'ordre « objectif » des souvenirs est construction et sédimentation par le langage et les repères, est idéalisation. La mémoire originaire est faite d'existentiaux qui, comme contours du paysage temporel, renferment possibilités instituées d'explicitations, matrices symboliques où les apports de la vie viennent s'inscrire et faire notre «monde» du pour autrui. Une personne, quelqu'un, est pour nous une telle matrice - de là les condensations et déplacements. Et le problème est de comprendre de quelle sorte est le savoir de présence. Je montre qu'il est perception-imperception, écart, et que tout ce qui s'y ajoute est encore écart, et que tout l'édifice d'une vie est aussi construit sur des différences de significations. Mais, de 
même que cette analyse saussurienne du langage renvoie à une source mythique du langage (la «convention »d'avant toutes les «conventions ») où se fait le surgissement du langage, de même l'analyse de la présence d'espace-temps comme degré zéro de toutes les variantes ultérieures renvoie à un horizon d'être.

s) Nota 41, 14 de junho de 1959 :

Insister sur le «passage » du présent : il passe i.e. il va plus loin, il s’éloigne, mais aussi, puisqu'il reste lui-même dans ce passage, et que je suis hanté par un autre présent, c'est moi qui éloigne. Comme dans le train : je vois les [vaches] passer et je sais bien que c'est moi qui passe, du moins [en portant mes yeux assez loin]. Le passé proche me semble s'éloigner. Le passé lointain ne bouge plus et c'est moi qui m'en éloigne. Husserl a bien vu que le temps ne paraît en-soi que dans le [... erinnerung] et non dans la rétention.

t) Nota 65b, do projeto de curso de 1959 :

Cours - conclusions

Montrer dans la conclusion que la question n'est pas du tout de savoir si la dialectique est «dans les choses » ou «dans les consciences ». Les deux attitudes sont anti-dialectiques.

Ce qui est dialectique, le seul milieu de la dialectique : «les relations entre personnes médiatisées par les choses ».

i.e. Stiftung et dialectique

La dialectique, par principe, dépasse le problème [décisionniste] : sens en soi ou sens pour ma Sinngebung. Certes elle n'opère pas de soi et il faut toujours qu'elle soit reprise par une conscience vivante pour opérer. Mais néanmoins elle n'est pas intérieure à cette conscience : elle a ses articulations, elle est un temps universel, qui ne trouve dans la temporalité du pour soi qu'une réplique et non son fondement.

u) Nota 14b, 27 de outubro de 1958 :

Temps - la réflexion sur le temps - [que ce soit Saint Augustin, Leibniz, ou Kant] - sous-entend toujours que la conscience du temps est conscience d'une série temporelle effective - on cherche cette série temporelle, on montre qu'elle ne peut être qu' « interne » (Husserl) ou qu'elle a en tous cas toujours de conditions internes (Kant) : 
mais on omet de remarquer que le temps, s'il doit pouvoir s'appliquer à toutes choses, ne saurait être l'une d'elles; que la conscience du temps ne peut être coïncidence avec .... ou constitution d'une série qui serait elle-même tout au plus un être temporel (un étant au sens de Heidegger).

On ne peut finalement comprendre le temps que comme «pivot», «matrice symbolique », ou Geschick: système signifiant, noyau de significations, articulation du Welt, son articulation fondamentale. Le recours à une série [intérieure ?] (ou à la conscience d'une série intérieure) n'avance à rien si cette série ne trouve pas son origine dans un type de déploiement de l'être, dans un [Fug ?] (Fug : droit, faculté ; Fuge : joint, jointure).

Mais alors comment faire comprendre (comment admettre même) la conséquence : que je ne suis pas dans [? ] le temps ? Pourtant, c'est bien sûr, je n'en suis qu'à ce point du temps où nous en sommes.

Réponse: preuve que c'est vraiment l'être qui se temporalise et non moi qui surajoute le temps à l'être comme condition de sa Gegenständigkeit.

v) Nota 10a, Novembro de 1959 :

La pensée est absolument comparable à la perception. C'est le jugement qui en diffère (la proposition) - mais la pensée productive, et aussi la pensée parlante (qui n'est pas faite de statements qui, comme la mélodie, n’est pas « réversible »), la «lumière naturelle » est absolument de l'ordre de la perception : il y a, ici, comme là, champ, matrices symboliques, lacunes, écueils, niveaux, transparences, perspectives - ici comme là le problème des «rapports » du sujet et de l'objet est dénué de sens. L'Être vu comme l'Être perçu est éminemment contenu dans l'Être. Le «problème » de la «préexistence » de vrai n'a pas plus de sens que celui de la préexistence de l'en soi physique.

x) Nota 41a, setembro de 1959 :

Croyons-nous à l'existence des hommes des antipodes ou des hommes des siècles passés ? Quand on voit photographie (ou cet après-midi tableau d'un pêcheur de Belle-Île par Monnet en 1886), on s'aperçoit que nous n'y croyons pas et ne pouvons pas y croire. Il faudrait nous installer dans un avant nous d'où nous serions futurs contingents, dans un loin de nous d'où nous serions une ombre, c'est impossible. La préexistence des hommes et du monde, nous n'y croyons que comme nous croyons à la 
chose avant l'éclairage qui la dévoile : parce qu'elle n'est pas éclairage, parce qu'elle a ses limites et que l'éclairage est un élément sans limites, parce que la perspective temporelle conduit vers ce qu'elle éclaire - le monde avant nous, avant les consciences, auquel nous croyons, c'est cet au-delà des limites de champ de notre vie, c'est l'Être. La mémoire du monde, c'est l'Être, c'est l'inscription.

z) Nota 31a, setembro de 1959 :

Non ? à la fin des phrases, sorte de particule ajoutée depuis 1930.

Cf. La particule Ti (Vendryès).

Il faut considérer le parole comme articulé sur des matrices symboliques, exactement au même titre que la perception. Matrices symboliques qui ne sont pas des [concepts], mais des pivots ou charnières, des systèmes tacites d'équivalence. Valeur d'emploi: structure perceptive. C'est par là qu'on voit que parler n'est pas penser le langage. Le langage se perçoit et se pratique comme l'espace brut se perçoit et se pratique dans le mouvement. 


\section{Referências bibliográficas}

ALQUIÉ, F. “Une philosophie de l'ambiguïté. L'existentialisme de Merleau-Ponty". Fontaine Vol. IX, n.59, 1947, p.47-70.

BARBARAS, R. "A phenomenology of life". In: Carman, T., Hansen M. (eds.). The Cambridge Companion to Merleau-Ponty. Cambridge: Cambridge Univ. Press, 2005, p.206-230.

De l'Être du Phénomène. Sur l'ontologie de Merleau-Ponty. Grenoble: Jérôme Millon, 2001.

Le Tournant de l'Expérience. Recherches sur la philosophie de MerleauPonty. Paris: Vrin, 1998.

BIMBENET, É. Nature et Humanité. Le problème anthropologique dans l'oeuvre de Merleau-Ponty. Paris: Vrin, 2004.

BONAN, R. Qu'est-ce qu'une Philosophie de la Science? Dijon-Quitigny: CNDT, 1997.

CARBONE, M. Il Sensibile e l'Eccedente. Mondo estetico, arte, pensiero. Milano: Guerini Studio, 1996.

"La dicibilité du monde. La période intermédiaire de la pensée de MerleauPonty à partir de Saussure”. In: VV.AA. Merleau-Ponty - le philosophe et son langage. Paris: Vrin, 1993, p.83-99.

CASSOUS-NOGUÈS, P. "La définition du sujet dans Le Visible et L'Invisible". In: Merleau-Ponty aux Frontières de l'Invisible. Milano: Mimesis, 2003, p.163-182.

CHAUI, M. Experiência do Pensamento. Ensaios sobre a obra de Merleau-Ponty. São Paulo: Martins Fontes, 2002.

COGHILL, G. E. Anatomy and the Problem of Behaviour. New York/London, Macmillan, 1929.

DASTUR, F. "La foi perceptive et l'invisible". In: Chair et Langage. Paris: Encre Marine, 2001.

DEPRAZ, N., "Selon quels critères peut-on définir une écriture phénoménologique?". In: VV. AA. Merleau-Ponty et le littéraire. Paris: Presses de l'École Normale Supérieure, 1997, p.39-51.

DESANTI, J. T. "Merleau-Ponty et la décomposition de l'idealisme". La Nouvelle Critique, n.37, 1951, p.63-82.

DILLON, M. C. Merleau-Ponty’s Ontology. Evanston: Northwestern Univ. Press, 1997.

EMBREE, L. "Gurwitsch's critique of Merleau-Ponty". In: Journal of the British Society for Phenomenology. Vol. 12, n. 2, 1981, p.150-163. 
FONTAINE, P. "Le concept phénoménologique d'horizon”. In: Cahiers Philosophiques, n. 87, juin 2001, p. 9-31.

GAGNON, M. "Étonnement et interrogation - Essai sur Merleau-Ponty". In: Revue Philosophique de Louvain, Vol. 93, n.3, 1995, p.370-391.

GÉLY, R. La Genèse du Sentir - Essai sur Merleau-Ponty. Bruxelles: Ousia, 2000.

GESELL, A., L'Embryologie du Comportement. Paris: PUF, 1945.

GURWITSCH, A. Théorie du Champ de la Conscience. Paris: Desclée de Brouwer, 1957.

Phenomenology of Thematics and of the Pure Ego: Studies of the Relation between Gestalt Theory and Phenomenology, In: Gurwitsch, A. Studies in Phenomenology and Psychology. Evanston: Northwestern University Press, 1966.

HAAR, M. "Proximité et distance vis-à-vis de Heidegger chez le dernier MerleauPonty". In: La Philosophie Française entre Phénoménologie et Métaphysique. Paris: PUF, 1999, p.9-34.

HEIDEGGER, M. Sein und Zeit. Tübingen: Max Niemeyer, 2002.

HUSSERL, E. Cartesianische Meditationen und Pariser Vorträge. Hua I. Haag: Martinus Nijhoff, 1950.

Die Krisis der europäischen Wissenschaften und die transzendentale Phänomenologie. Hua. VI. Haag: Martinus Nijhoff, 1962.

Nijhoff, 1950.

Die Idee der Phänomenologie - Fünf Vorlesungen. Hua. II, Haag: Martinus Ideen zu einer reinen Phänomenologie und phänomenologischen Philosophie I. Hua. III. Haag: Martinus Nijhoff, 1950.

Martinus Nijhoff, 1984.

Umsturz der kopernikanischen Lehre: die Erde als Urarche bewegt sich nicht. In: M. Farber (org.), Philosophical Essays in Memory of Edmund Husserl, Cambridge: Harvard U.P., 1940.

KANT, I. Critique of Pure Reason. Transl. by Guyer, P. and Wood, A. W. Cambridge: Cambridge Univ. Press, 1998.

MADISON, G. B. The Phenomenology of Merleau-Ponty. A search for the limits of consciousness. Athens: Ohio Univ. Press, 1981.

MAURO, T. de. Une Introduction à la Sémantique. Paris: Payot, 1969. 
MERLEAU-PONTY, M. Discusion. In: Husserl. Tercer Colóquio Filosófico de Royaumont. Buenos Aires: Paidos, 1968.

"Notes de lecture et commentaires sur Théorie du champ de la conscience de Aron Gurwitsch”. In: Revue de Métaphysique et de Morale, n. 3, 1997, p.321-342.

MOURA, C. A. R. de, "Entre fenomenologia e ontologia: Merleau-Ponty na encruzilhada". In: Racionalidade e Crise. SP: Discurso e UFPR Ed., 2001, p. 271-293.

MOUTINHO, L. D. S. Razão e Experiência. Ensaio sobre Merleau-Ponty. SP: Unesp/FAPESP, 2006.

PEILlON, V. La Tradition de l'Esprit. Itinéraire de Maurice Merleau-Ponty. Paris: Bernard Grasset, 1994.

PIETERSMA, H. Phenomenological Epistemology. Oxford: Oxford Univ. Press, 2002.

PINTOS PEÑARANDA, M. L. "Gurwitsch, Goldstein, Merleau-Ponty. Analyse d'une étroite relation”. In: Chiasmi International, n.6, 2004, p.147-171.

PRIEST, S. Merleau-Ponty. London: Routledge, 2003.

ROBERT, F. Phénoménologie et Ontologie. Merleau-Ponty lecteur de Husserl et Heidegger. Paris: L'Hamarttan, 2005.

SAINT AUBERT, E. Du Lien des Êtres aux Éléments de l'Être. Merleau-Ponty au tournant des années 1945-51. Paris: Vrin, 2004.

- Vers une Ontologie Indirecte. Sources et enjeux critiques de l'appel à l'ontologie chez Merleau-Ponty. Paris: Vrin, 2006.

SAUSSURE, F. de Cours de Linguistique Générale. Edition critique. Paris: Payot, 1985.

SOSA, E. “Putnam's Pragmatic Realism”. In: The Journal of Philosophy, Vol. 90, n.12, 1993, p.605-626.

TAMINIAUX, J. "La phénoménologie dans le dernier ouvrage de Merleau-Ponty". In : Le Regard et l'Excédent. La Haye : Martinus Nijhoff, 1977, p.72-89.

TOADVINE, T. "Merleau-Ponty's reading of Husserl : a chronological overview". In : Toadvine, T.; Embree, L. (ed.). Merleau-Ponty's reading of Husserl. Boston: Kluwer Ac. Publisher, 2002, p. 227-286.

THIERRY, Y. Du corps parlant. Le langage chez Merleau-Ponty. Bruxelles: Ousia, 1987.

TRÉGUIER, J. M. Le Corps selon la Chair. Paris: Kimé, 1996. 
VAN BREDA, H. L. "Maurice Merleau-Ponty et les archives-Husserl à Louvain". In : Revue de Métaphysique et de Morale, n. 4, 1962, p.410-430.

ZAHAVI, D. "Merleau-Ponty on Husserl: a Reappraisal". In : Toadvine, T.; Embree, L. (eds.). Merleau-Ponty's reading of Husserl. Boston: Kluwer Ac. Publisher, 2002, p.329. 